DOE/OR/01-1290\&D1

\title{
Third Annual Environmental Restoration Monitoring and Assessment Report for FY 1994 of the Oak Ridge National Laboratory, Oak Ridge, Tennessee
}

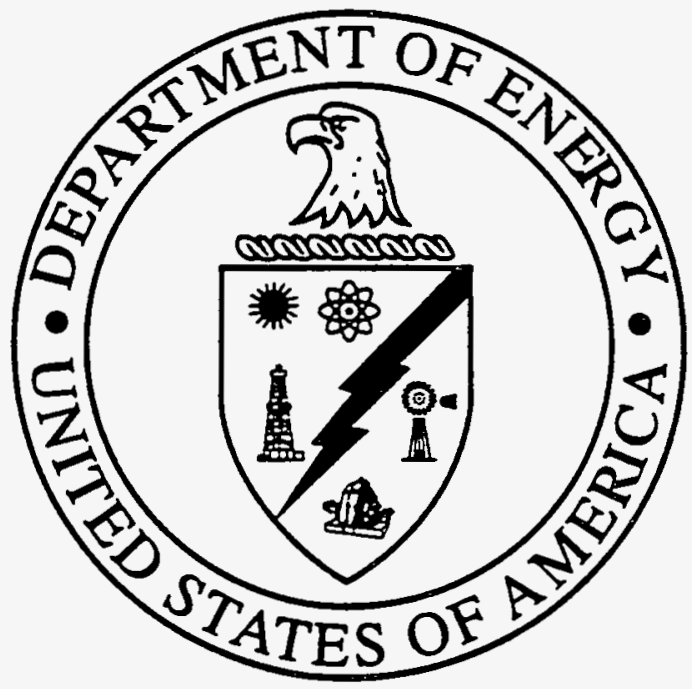


This report has been reproduced directly from the best available copy.

Available to DOE and DOE contractors from the Office of Scientific and Technical Information, P.O. Box 62, Oak Ridge, TN 37831; prices available from 615-576-8401.

Available to the public from the National Technical Information Service, U.S. Department of Commerce, 5285 Port Royal Rd., Springfield, VA 22161. 


\section{DISCLAIMER}

This report was prepared as an account of work sponsored by an agency of the United States Government. Neither the United States Government nor any agency thereof, nor any of their employees, make any warranty, express or implied, or assumes any legal liability or responsibility for the accuracy, completeness, or usefulness of any information, apparatus, product, or process disciosed, or represents that its use would not infringe privately owned rights. Reference herein to any specific commercial product, process, or service by trade name, trademark, manufacturer, or otherwise does not necessarily constitute or imply its endorsement, recommendation, or favoring by the United States Government or any agency thereof. The views and opinions of authors expressed herein do not necessarily state or reflect those of the United States Government or any agency thereof. 


\section{DISCLAIMER}

Portions of this document may be illegible in electronic image products. Images are produced from the best available original document. 
DOE/OR/01-1290\&D1

ORNL/ER-250

Energy Systems Environmental Restoration Program

ORNL Environmental Restoration Program

\section{Third Annual Environmental Restoration Monitoring and Assessment Report for FY 1994 of the Oak Ridge National Laboratory, Oak Ridge, Tennessee}

R. B. Clapp,

J. A. Watts, and

M. A. S. Guth, Editors

Date Issued-September 1994

Prepared by

Environmental Sciences Division

Oak Ridge National Laboratory

ESD Publication 4301

Prepared for

U.S. Department of Energy

Office of Environmental Restoration and Waste Management under budget and reporting code EW 20

Environmental Restoration and Waste Management Programs

Oak Ridge National Laboratory

Oak Ridge, Tennessee 37831-6285

managed by

MARTIN MARIETTA ENERGY SYSTEMS, INC.

for the

U.S. DEPARTMENT OF ENERGY

under contract DE-AC05-84OR21400 


\section{Contributors}

$\begin{array}{llll}\text { S. M. Adams } & \text { T.A. Fontaine } & \text { R.H. Ketelle } & \text { J.G. Smith } \\ \text { T. L. Ashwood } & \text { M.S. Greeley } & \text { J.M. Loar } & \text { G.R. Southworth } \\ \text { L. A. Baron } & \text { M. A. S. Guth } & \text { R. S. Loffman } & \text { R. T. Stevens } \\ \text { B. G. Blaylock } & \text { J. P. Gwo } & \text { T. D. Moore } & \text { A. J. Stewart } \\ \text { D. M. Borders } & \text { S. E. Herbes } & \text { B. R. O'Neal } & \text { G. W. Suter } \\ \text { C. A. Branson } & \text { D. S. Hicks } & \text { M. J. Peterson } & \text { M. F. Tardiff } \\ \text { B. B. Burgoa } & \text { W. R. Hill } & \text { S. T. Purucker } & \text { L. E. Toran } \\ \text { R. B. Clapp } & \text { R. L. Hinzman } & \text { S. M. Ratnayeke } & \text { K. M. Turnage } \\ \text { D. K. Cox } & \text { P. M. Jardine } & \text { W. Sanford } & \text { J. A. Watts } \\ \text { W. D. Crumby } & \text { D. S. Jones } & \text { E. M. Schilling } & \end{array}$

\section{Contributor Affiliations}

S. M. Adams, T. L. Ashwood, B. G. Blaylock, R. B. Clapp, D. K. Cox, T. A. Fontaine, M. S. Greeley, S. E. Herbes, D. S. Hicks, W. R. Hill, R. L. Hinzman, P. M. Jardine, J. M. Loar, M. J. Peterson, S. T. Purucker, E. M. Schilling, J. G. Smith, G. R. Southworth, A. J. Stewart, G. W. Suter, L. E. Toran, and J. A. Watts are members of the Environmental Sciences Division of Oak Ridge National Laboratory (ORNL), Martin Marietta Energy Systems, Inc.; M. F. Tardiff and R. S. Loffman are members of the Office of Environmental Compliance and Documentation at ORNL; and R. H. Ketelle is a member of the Energy Division, ORNL. D. M. Borders, T. D. Moore, and W. Sanford are research associates in the Department of Civil Engineering, The University of Tennessee, Knoxville (UTK). B. B. Burgoa is a research associate in the Plant and Soil Science Department, UTK. J. P. Gwo, D. S. Jones, K. M. Turnage, and R. T. Stevens are postgraduate fellows at Oak Ridge Institute for Science and Education. S. M. Ratnayeke is a research assistant working on his Ph.D. in plant physiology at UTK. M. A. S. Guth was formerly with Gilbert/Commonwealth, Inc., and is presently with UTK Law School. C. A. Branson is a subcontract staff member with Midwest Technical, Inc. W. D. Crumby is a subcontract staff member with Automated Science Group, Inc. B. R. O'Neal and L. A. Baron are subcontract staff with Jaycor, Inc.

\section{Acknowledgments}

Special thanks to the following for their support in document preparation:
D. M. Adams
S. E. Herbes
D. J. Pridmore
M. D. Bryant
V. L. Holt
D. K. Reece
A. S. Carr
C. How
D. D. Rhew
T. B. Coffey
I. L. Larson
J. A. Shaakir-Ali
J. S. Cox
S. Y. Lee
D. B. Watson
Y. S. Cox
W. L. McCalla
B. J. Fredrick
J. L. Morris
R. F. Winterfield
A. L. Harkey
J. J. Olson
K. Y. Henley
R. B. Petrie
K. S. Ziegler 


\section{CONTENTS}

FIGURES $\ldots \ldots \ldots \ldots \ldots \ldots \ldots \ldots \ldots \ldots \ldots \ldots \ldots \ldots \ldots \ldots \ldots$ vii

TABLES $\ldots \ldots \ldots \ldots \ldots \ldots \ldots \ldots \ldots \ldots \ldots \ldots \ldots \ldots \ldots \ldots \ldots \ldots \ldots \ldots$

ABBREVIATIONS $\ldots \ldots \ldots \ldots \ldots \ldots \ldots \ldots \ldots \ldots \ldots \ldots \ldots \ldots \ldots \ldots \ldots$ xiii

EXECUTIVE SUMMARY $\ldots \ldots \ldots \ldots \ldots \ldots \ldots \ldots \ldots \ldots \ldots \ldots$

1. INTRODUCTION $\ldots \ldots \ldots \ldots \ldots \ldots \ldots \ldots \ldots \ldots \ldots \ldots \ldots \ldots \ldots \ldots \ldots \ldots \ldots, 1-1$

1.1 ORNL SITE ............................... $1-2$

1.2 SITE-WIDE INTEGRATED APPROACH TO ENVIRONMENTAL

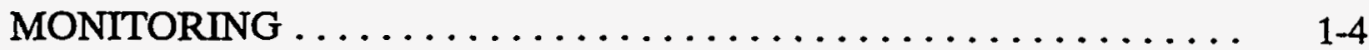

1.2.1 WAG 2/SI Project Objectives $\ldots \ldots \ldots \ldots \ldots \ldots \ldots \ldots \ldots \ldots \ldots$ 1-6

1.2.2 ERMA Strategy and Organization ................. 1-7

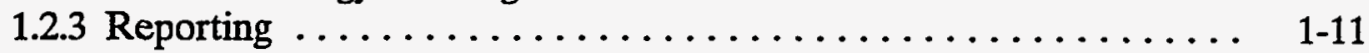

1.2.4 Data Quality .......................... 1-12

1.3 RECENT ACTIVITIES AT THE ORNL WAGS ............ 1 . 12

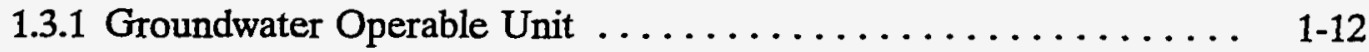

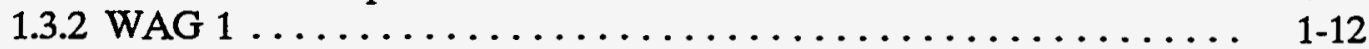

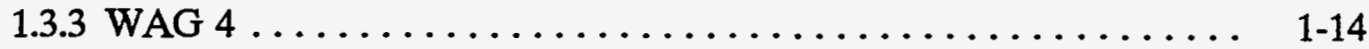

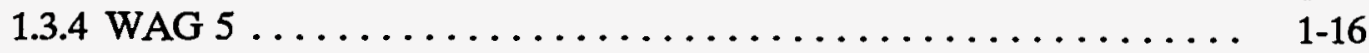

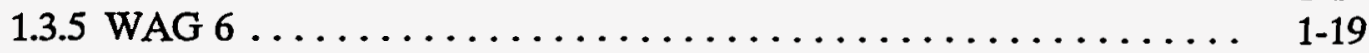

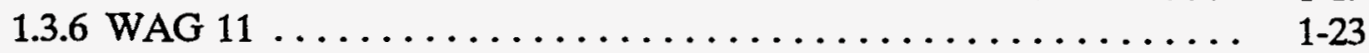

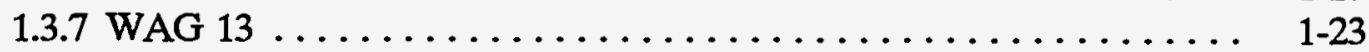

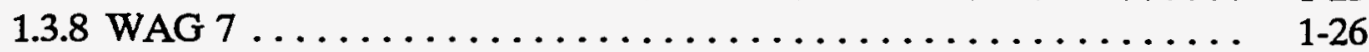

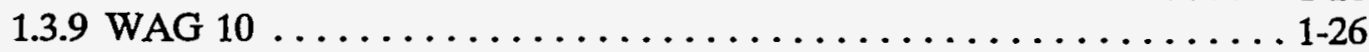

1.4 THE FYDROLOGIC SYSTEM AT ORNL . . . . . . . . . 1 1-27

2. SURFACE WATER $\ldots \ldots \ldots \ldots \ldots \ldots \ldots \ldots \ldots \ldots \ldots \ldots \ldots \ldots \ldots \ldots \ldots, 2-1$

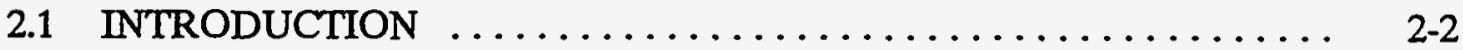

2.2 HYDROLOGIC CONCEPTUAL MODEL: CONTAMINANT

DISCHARGE FROM TRIBUTARIES ................. 2 . 2

THE HYDROLOGIC SYSTEM AT ORNL .............. 2 . 2

2.3 SURFACE WATER HYDROLOGY $\ldots \ldots \ldots \ldots \ldots \ldots \ldots \ldots \ldots . . \ldots \ldots$

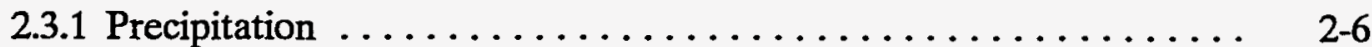

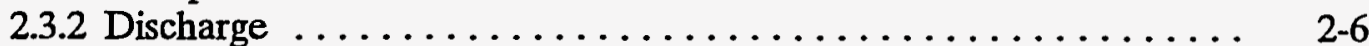

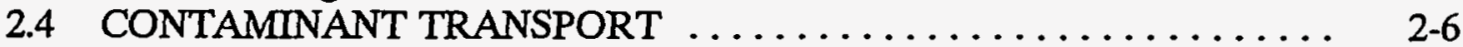

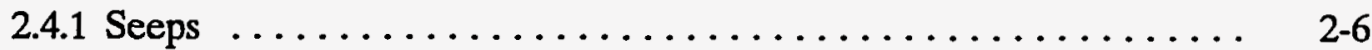

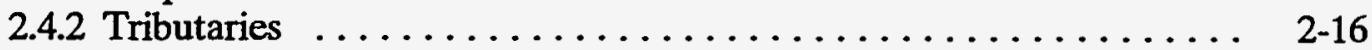

2.4.3 Nonradiological Contaminant Discharge .............. 2-26

2.4.4 Radionuclide Fluxes at Main Stations ... . . . . . . . . . . . . 2-26

2.5 CONTAMINANT FLUX DYNAMICS ................... 2 . 29

2.5.1 Storm Response .......................... 2-29

2.5.2 Seasonal Response .................... 2-32 
2.5.3 Implications to Environmental Restoration ............ 2-32

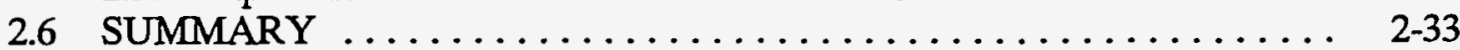

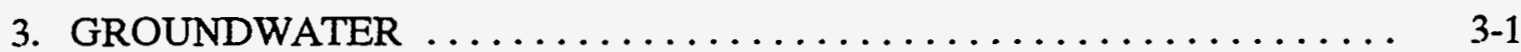

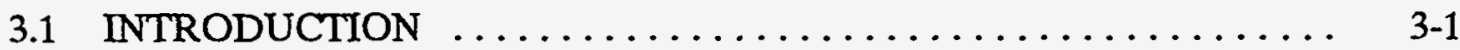

3.2 AREA GROUNDWATER PROGRAM INTERACTIONS WITH CONTAMINANT SOURCE WAG ACTIVITIES ............ 3-1

3.3 WAG PERIMETER WATER QUALITY MONTTORING ......... 3-

3.3.1 Summary of FY 1993 WAG Perimeter Well Data .......... 3-3

3.3.2 Potential Risk Associated with ORNL Groundwater . . . . . . . . 3- 3-7

3.3.3 Temporal Contaminant Concentration Variation ........... 3-7

3.4 GROUNDWATER MODELING .................. $3-11$

3.4.1 WAG 6 Groundwater Flux Calculations .............. 3-11

3.4 .2 Effect of Caps on Stormflow .................. 3-11

3.4.3 Regional Groundwater Flow Modeling .............. 3-12

3.4.4 Fracture Flow Modeling of Transport on

the Reservation ...................... 3-12

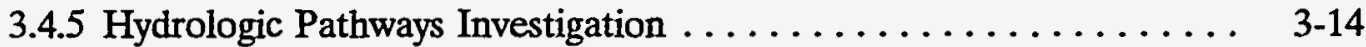

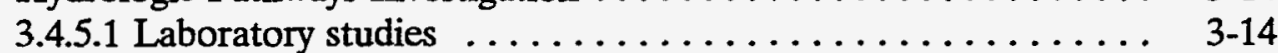

3.4.5.2 Field studies ....................... 3-15

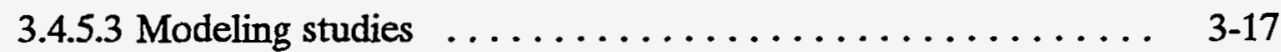

3.4.5.4 Benefits to remediation $\ldots \ldots \ldots \ldots \ldots \ldots \ldots \ldots \ldots$ 3-17

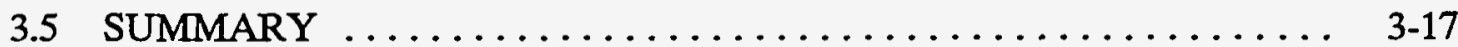

4. SOIL AND SEDIMENTS $\ldots \ldots \ldots \ldots \ldots \ldots \ldots \ldots \ldots \ldots \ldots \ldots \ldots$ 4

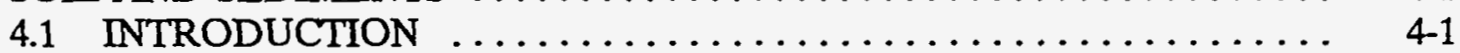

4.2 CONCEPTUAL MODEL FOR CONTAMINATED SEDIMENT

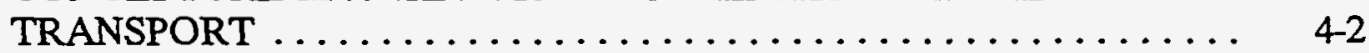

4.2 .1 Sediment Sources $\ldots \ldots \ldots \ldots \ldots \ldots \ldots \ldots \ldots \ldots \ldots \ldots . \ldots \ldots$ 4-2

4.2.2 Primary Contaminant Sources ................. 4-4

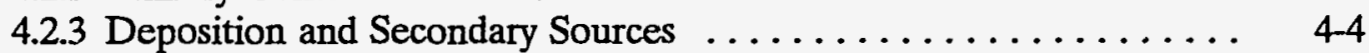

4.2.4 Transport Processes ........................ 4 .4

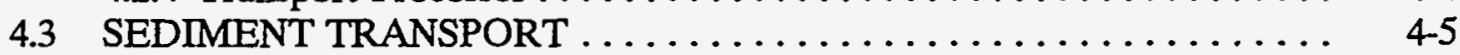

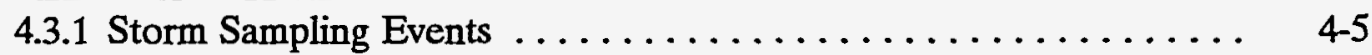

4.3.2 Analysis of the 04DEC93 Storm Event ............. 4 .5

4.3.3 Hydrographs and Sediment Loads ............... 4-6

4.3.4 Contaminant Analysis . . . . . . . . . . . . . . . 4 4 41

4.3 .5 Grain Size Analysis . . . . . . . . . . . . . . . . . . 4 4

4.3.6 Summary of Storm Sampling Results ............... 4 4 4 .15

4.4 CONTAMINANT SOURCES IN WAG $2 \ldots \ldots \ldots \ldots \ldots \ldots \ldots \ldots . \ldots \ldots$

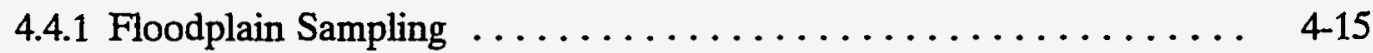

4.4.2 Weir Pool Sediment Sampling . . . . . . . . . . . . 4 4

4.5 EROSION

4.5.1 Stream Bank and Channel Erosion ............... 4-21

4.5.2 Soil Erosion ........................... 4-21

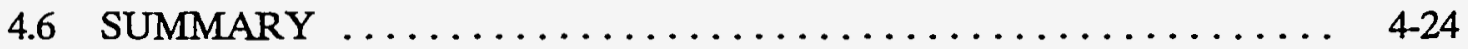

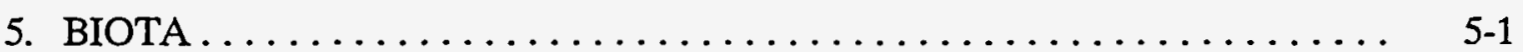

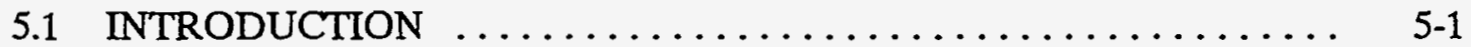

5.2 TOXICITY MONITORING .................... $5-2$ 
5.3 BIOACCUMULATION STUDIES $\ldots \ldots \ldots \ldots \ldots \ldots \ldots \ldots \ldots \ldots$

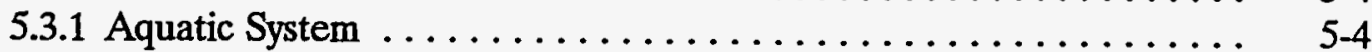

5.3.2 Terrestrial System $\ldots \ldots \ldots \ldots \ldots \ldots \ldots \ldots \ldots \ldots \ldots . \ldots \ldots$ 5-7

5.4 BIOLOGICAL INDICATORS OF CONTAMINANT STRESS $\ldots . . . \quad 5-11$

5.4.1 Integrated Fish Health (Component 2) ............ 5-11

5.4.2 Reproductive and Developmental Competence

(Component 3) ......................... 5-12

5.4 .3 Population Analysis ......................... $5-12$

5.5 INSTREAM ECOLOGICAL MONTTORING $\ldots \ldots \ldots \ldots \ldots \ldots \ldots .5-12$

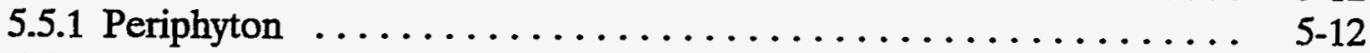

5.5 .2 Benthic Macroinvertebrates ................... 5-14

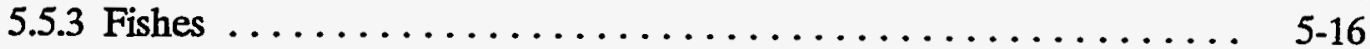

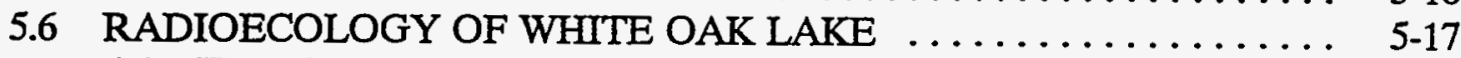

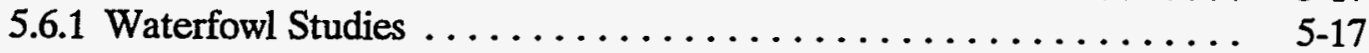

5.6 .2 Radioactivity in Fish $\ldots \ldots \ldots \ldots \ldots \ldots \ldots \ldots \ldots \ldots . \ldots \ldots$ 5-18

5.6.3 Radioactivity in Floating Vegetation in

White Oak Creek Embayment $\ldots \ldots \ldots \ldots \ldots \ldots \ldots \ldots \ldots$ 5-18

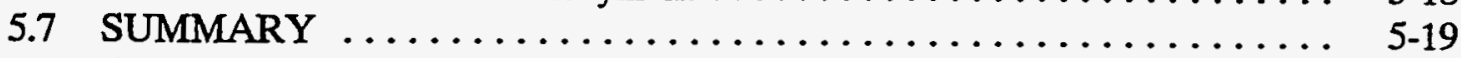

5.7.1 Growth and Propagation of Fish and Aquatic Life ... . . . . . 5 5-19

5.7.2 Livestock Watering and Wildlife $\ldots \ldots \ldots \ldots \ldots \ldots \ldots \ldots \ldots . \ldots \ldots$ 5-22

6. CONTAMINANTS OF CONCERN AND RISK ASSESSMENT . . . . . . . 6-1

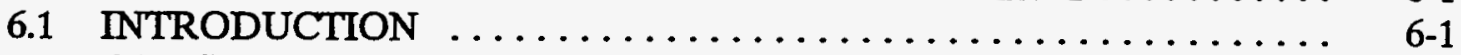

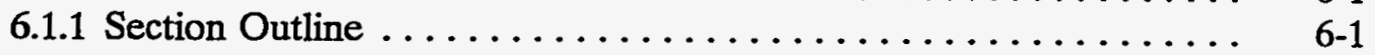

6.1.2 Assessment and Decision Making ................ 6-1

6.2 HUMAN HEALTH AND RISK ASSESSMENT AND

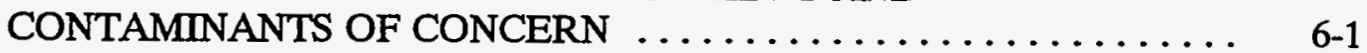

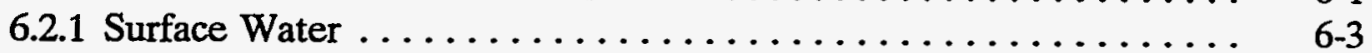

6.2.1.1 Calculation of risk $\ldots \ldots \ldots \ldots \ldots \ldots \ldots \ldots \ldots \ldots$ 6-6

6.2.1.2 Contaminants of concern in surface water ......... 6-6

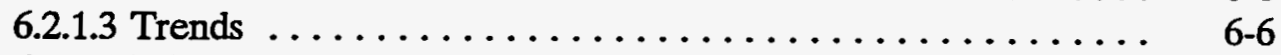

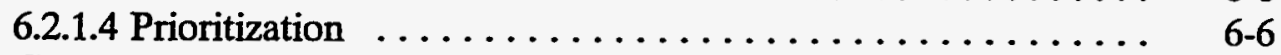

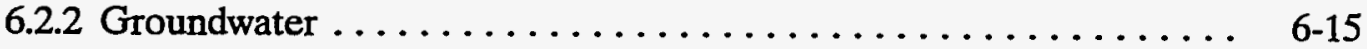

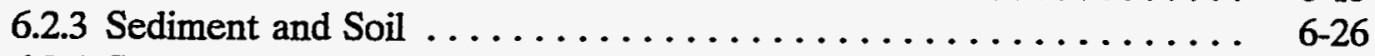

6.2 .4 Source WAGs . . . . . . . . . . . . . . . . . . . . 6-29

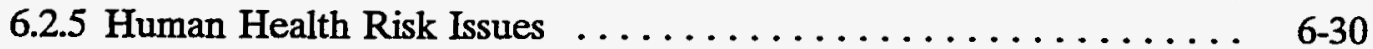

6.3 ECOLOGICAL RISK ......................... $6-30$

6.3.1 General Approach ...................... 6-33

6.3.2 Ecological risk assessment activities at ORNL .......... 6-34

6.3.3 Challenges for ecological risk assessments at
Oak Ridge Reservation $\ldots \ldots \ldots \ldots \ldots \ldots \ldots \ldots \ldots \ldots \ldots . \ldots \ldots \ldots$

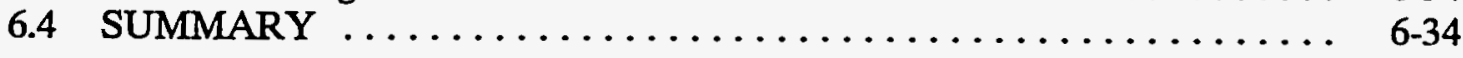

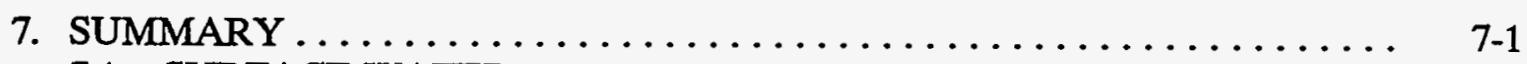

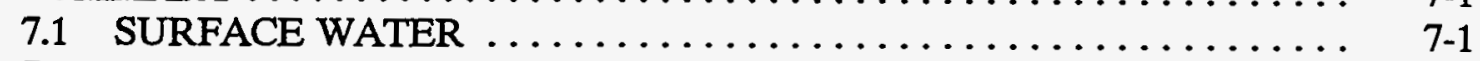

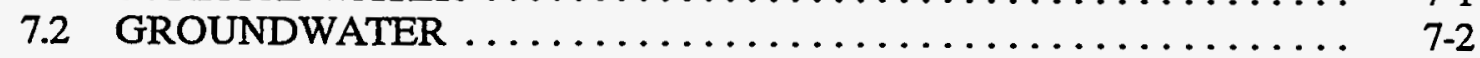

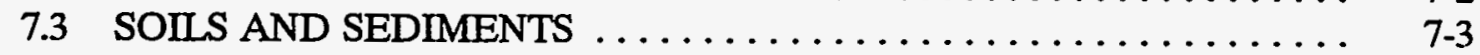

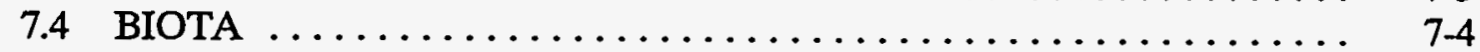

7.5 RISK ASSESSMENT $\ldots \ldots \ldots \ldots \ldots \ldots \ldots \ldots \ldots \ldots \ldots \ldots \ldots \ldots . \ldots \ldots$

7.6 ADDITIONAL DATA NEEDS AND UPCOMING EFFORTS ..... 7-6 
Appendix A. Graphs of Contaminant Fluxes in the White Oak Creek

Watershed, 1993 ............................ A-1

Appendix B. Graphs of the Risk History at Selected Groundwater Wells ........ B-1

Appendix C. Figures from Ecological Risk Sect. $6.3 \ldots \ldots \ldots \ldots \ldots \ldots \ldots$ C-1 


\section{FIGURES}

1.1 Map showing ORNL waste area groupings $\ldots \ldots \ldots \ldots \ldots \ldots$

1.2 Map showing the groundwater operable unit, which is divided into

Bethel Valley and Melton Valley units .................. 1-5

1.3 Major tasks for the Waste Area Grouping 2/Site Investigation Project ... $1-8$

1.4 ORNL Waste Area Grouping $1 \ldots \ldots \ldots \ldots \ldots \ldots \ldots \ldots \ldots \ldots \ldots$

$1.5 \quad$ WAG 1 Surface Impoundments $\ldots \ldots \ldots \ldots \ldots \ldots \ldots \ldots \ldots \ldots$

1.6 ORNL Waste Area Grouping $4 \ldots \ldots \ldots \ldots \ldots \ldots \ldots \ldots \ldots \ldots \ldots$

1.7 ORNL Waste Area Grouping $5 \ldots \ldots \ldots \ldots \ldots \ldots \ldots \ldots \ldots \ldots \ldots$

1.8 ORNL Waste Area Grouping $6 \ldots \ldots \ldots \ldots \ldots \ldots \ldots \ldots \ldots \ldots \ldots$

1.9 Contaminant discharge to White Oak Dam $\ldots \ldots \ldots \ldots \ldots \ldots \ldots \ldots$ 1-21

1.10 Waste Area Grouping 6 flow path groups $\ldots \ldots \ldots \ldots \ldots \ldots \ldots \ldots$ 1-22

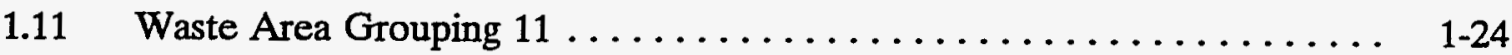

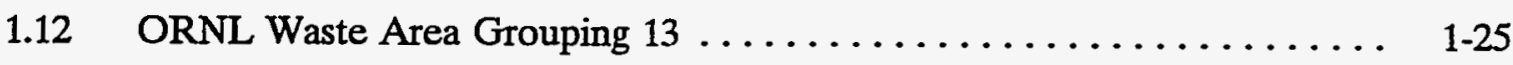

1.13 Conceptual hydrologic model for subsurface flow in shale aquitard at the Oak Ridge Reservation $\ldots \ldots \ldots \ldots \ldots \ldots \ldots \ldots \ldots$ 1-28

2.1 Conceptual model for tributaries draining ORNL waste sites ....... 2-4

2.2 Conceptual model relating discharge, contaminant flux and contaminant concentration vs time in (A) and log transformation in (B) ... 2-5

2.3 Locations of surface water monitoring stations in the vicinity of White Oak Creek watershed $\ldots \ldots \ldots \ldots \ldots \ldots \ldots \ldots \ldots \ldots \ldots$

2.4 Network of reaches for the White Oak Creek surface water

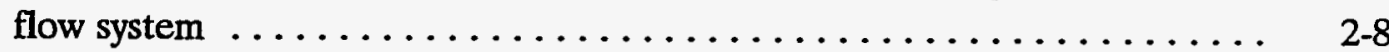

2.5 Waste Area Grouping 2 Seep Task sampling locations in $1993 \ldots \ldots$. . . 2-11

2.6 Waste Area Grouping 2 Seep Task bimonthly sampling locations . . . . . 2-12

$2.7{ }^{3} \mathrm{H}$ results from sampling along a transect of Melton Branch $\ldots \ldots \ldots . .2-13$ 
$2.8{ }^{90} \mathrm{Sr}$ results from sampling along a transect of Melton Branch

$2.9 \quad{ }^{3} \mathrm{H}$ results from sampling along a transect of the

Waste Area Grouping 4 tributary . . . . . . . . . . . . . . . .

$2.10{ }^{90} \mathrm{Sr}$ results from sampling along a transect of the

Waste Area Grouping 4 tributary . . . . . . . . . . . . . . . .

2.11 Distribution of tritium fluxes in the White Oak Creek

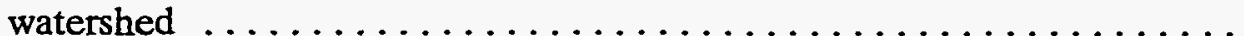

2.12 Distribution of ${ }^{90} \mathrm{Sr}$ fluxes in the White Oak Creek

watershed

2.13 Tributary Assessment Task sampling sites $\ldots \ldots \ldots \ldots \ldots \ldots \ldots$

2.14 Tritium concentration (C) vs discharge (Q) for samples collected from MS1 on the tributary draining

Waste Area Grouping 4 to White Oak Creek for storms A and D ......

2.15 Strontium-90 concentration (C) vs discharge (Q) for samples collected from MS1 on the tributary draining Waste Area Grouping 4 to White Oak Creek for storms A and D ......

2.16 Total radioactive strontium concentration vs discharge

for monthly flow proportional data at White Oak Creek

2.17 (a) Cumulative total radioactive strontium flux at

White Oak Dam, White Oak Creek weir, and Melton Branch weir;

(b) time series plots of rainfall and stream discharge for each of

the basins represented in part (a) $\ldots \ldots \ldots \ldots \ldots \ldots \ldots \ldots \ldots \ldots$

3.1 Location of wells from which water level data have been

measured June 1, 1993, through June 1, 1994

3.2 Spatial distribution of risk generating contaminants at

Oak Ridge National Laboratory . . . . . . . . . . . . . . . . . . . .

3.3 Vector diagram of flow under caps $\ldots \ldots \ldots \ldots \ldots \ldots \ldots \ldots \ldots \ldots$

3.4 Observed and model simulated effluent concentrations for $\mathrm{Br}$ displacement through undisturbed weathered shale at two pore water velocities.......

3.5 Two-dimensional cross-section of the tracer injection site at Waste Area Grouping 5 showing the injection and multilevel sampling wells .......

4.1 Conceptual model for contaminated sediment transport in

the White Oak Creek basin

4.2 Sampling sites for the December 4,1993 , storm ............. 
4.3 Storm analysis at White Oak Creek watershed for December 4, $1993 \ldots \ldots$

4.4 Storm analysis at Melton Branch weir for December 4, $1993 \ldots \ldots \ldots \ldots$

4.5 Flow, suspended sediment concentration [ss], gamma, and cumulative flux

4-10

4.6 Grain size comparisons along the White Oak Creek for the

December 4, 1993, storm

4.7 Grain size comparison before and after weir pools at

Melon Branch weir and White Oak Creek weir

(storm December 4, 1993)

4.8 Floodplain sampling locations

4.9 Example of ${ }^{137} \mathrm{Cs}$ profiles along a transect (collected in

January 1994)

4.10 Sediment sampling locations at weir pools and stream erosion

study areas

4.11 Stream bank erosion measured at sites along White Oak Creek

over a 14 -month period $\ldots \ldots \ldots \ldots \ldots \ldots \ldots \ldots \ldots \ldots \ldots \ldots \ldots \ldots \ldots \ldots$

5.1 Location of liquid and solid radioactive waste disposal/

storage areas: National Pollutant Discharge Elimination System

monitoring sites on Melton Branch, White Oak Creek, and White Oak Dam; and sampling sites for benthic invertebrates and fish in

White Oak Creek watershed

5.2 Average concentrations of mercury in sunfish collected

from November 1992 to March 1993 at sites on the Oak Ridge

Reservation

5.3 Average concentrations of polychlorinated biphenyls

in sunfish collected from November 1992 to March 1993 at sites on

the Oak Ridge Reservation . . . . . . . . . . . . . . . .

5.4 Segregation of integrated health responses for male redbreast sunfish collected from 1989 to 1992 at three reference streams

and White Oak Creek

6.1 Annual estimates of ingestion risk at White Oak Dam .......... $6-4$

6.2 Potential risk associated with contaminants at White Oak Dam and in the Clinch River $\ldots \ldots \ldots \ldots \ldots \ldots \ldots \ldots \ldots \ldots \ldots \ldots \ldots \ldots$

6.3 White Oak Dam ingestion risk and relative contaminant contribution ... 
6.4 Contaminant transfers among operable units

A-1 Monthly ${ }^{3} \mathrm{H}$ discharge at gaging stations located in

Middle White Oak Creek in 1993

A-2 Monthly total strontium discharge at gaging stations located

in Middle White Oak Creek in 1993

A-3 Monthly ${ }^{137} \mathrm{Cs}$ discharge at gaging stations located in

Middle White Oak Creek in 1993

A-4 Monthly ${ }^{60} \mathrm{Co}$ discharge at gaging stations located in

Middle White Oak Creek in 1993

A-5 Monthly ${ }^{3} \mathrm{H}$ discharge at gaging stations located in

Lower White Oak Creek and White Oak Lake in 1993

A-6 Monthly total Sr discharge at gaging stations located in

Lower White Oak Creek and White Oak Lake in 1993

A-7 Monthly ${ }^{137} \mathrm{Cs}$ discharge at gaging stations located in

Lower White Oak Creek and White Oak Lake in 1993

A-8 Monthly ${ }^{60} \mathrm{Co}$ discharge at gaging stations located in

Lower White Oak Creek and White Oak Lake in 1993

B-1 Risk history at WAG 5 well 973 , risk group $1 \ldots \ldots \ldots \ldots$ B-3

B-2 Risk history at WAG 4 well 958 , risk group $2 \ldots \ldots \ldots \ldots$ B-4

B-3 Risk history at WAG 4 well 954 , risk group $2 \ldots \ldots \ldots \ldots$ B-5

B-4 Risk history at WAG 1 well 812 , risk group $3 \ldots \ldots \ldots \ldots \ldots$

C-1 Contaminant transfer through a source operable unit and into integrator operable units

C-2 Aquatic biota compartments for source and aquatic integrator operable units

C-3 Transfer of contaminants into and through an aquatic integrator operable units

C-4 Transfer of contaminants into and through a groundwater integrator operable units

C-5 Transfer of contaminants from source and aquatic integrator operable units to the terrestrial integrator operable units 


\section{TABLES}

2.1 Stream reaches in the White Oak Creek Watershed $\ldots \ldots \ldots \ldots \ldots$

2.2 Ranking of Tributary Assessment Task Phase I sites for ${ }^{3} \mathrm{H},{ }^{90} \mathrm{Sr}$, gross alpha, gross beta, ${ }^{137} \mathrm{Cs}$, and ${ }^{60} \mathrm{Co}$ based on concentration and flux ...

2.3 Annual fluxes and mass balances for radionuclides in

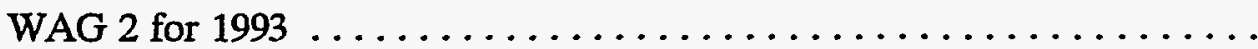

3.1 Chemical carcinogens detected at lest once in the Oak Ridge National Laboratory waste area grouping perimeter monitoring

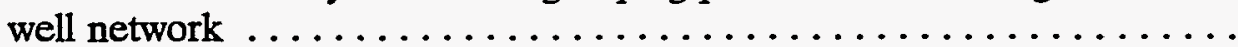

3.2 Total carcinogenic risk associated with each well organized by the waste area grouping which the well monitors

4.1 Estimates of sediment discharge and accumulation in the Lower White Oak Creek and White Oak Lake Reach ..

4.2 Sediment accumulation in stilling pools at the White Oak Creek weir and Melton Branch weir during the initial 6 hours of the 04DEC93 storm ....

4.3 Comparison of the sediment loads at White Oak Creek weir, White Oak

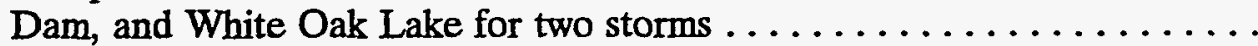

4.4 Contaminant concentrations in weir pool sediments greater than risk criteria

4.5 Areas and erosion rates for different land use systems

5.1 Radionuclide and trace metal concentrations in various kingfisher samples from the Oak Ridge Reservation $\ldots . \ldots \ldots \ldots \ldots$.

6.1 Waste area grouping prioritization and percent contribution to White Oak Dam risk

6.2 Contaminants exceeding risk criteria in RCRA perimeter wells . 


\section{ABBREVIATIONS}

CERCLA Comprehensive Environmental Response, Compensation, and Liability Act DOE Department of Energy

ER environmental restoration

ERMA

HSPF

MEK

ORNL

PCB

Environmental Restoration Monitoring and Assessment

Hydrologic Simulation Package - Fortran

Melton Branch kilometer

Oak Ridge National Laboratory

polychlorinated biphenyl

RCRA

SI

SWSA

WAG

WCK

Resource Conservation and Recovery Act

site investigation

solid waste storage area

waste area grouping

White Oak Creek kilometer 



\section{EXECUTIVE SUMMARY}

This report summarizes the salient features of the annual efforts of environmental monitoring, field investigations, and assessments conducted to support the Environmental Restoration (ER) Program at the Oak Ridge National Laboratory (ORNL). This report focuses on the watershed scale, providing an ORNL site-wide perspective on types, distribution, and transport of contamination. The results presented are used to enhance the conceptual understanding of the key contaminants and the sources, fluxes, and processes affecting their distribution and movement. This information forms a basis for prioritizing sites and for selecting, implementing, and evaluating remedial actions.

This report summarizes the efforts of the Waste Area Grouping (WAG) 2 and Site Investigations (SI) Project. WAG 2 is the lower portion of the White Oak Creek system which drains the major contaminated sites at ORNL and discharges to the Clinch River where public access is allowed. The Remedial Investigation Plan (DOE 1992) for WAG 2 includes a long-term multimedia environmental monitoring effort that takes advantage of WAG 2's role as an integrator and the major conduit of contaminants from the ORNL site. During FY 1992, the remedial investigation activities were integrated with a series of environmental monitoring and SI activities at ORNL that address pathways and processes important for contaminant movement to gain a more integrated perspective of contamination movement at the watershed scale.

In addition to the results from WAG 2/SI monitoring and field investigations, this report includes information from other site-specific remedial investigations and feasibility studies for contaminated sites at ORNL and data from other ongoing monitoring programs conducted by other organizations (e.g., the National Pollutant Discharge Elimination System compliance monitoring conducted by the Environmental Surveillance and Protection Section of the Office of Environmental Compliance and Documentation). This information is included to provide an integrated basis to support ER decision making. This report summarizes information gathered through early 1994. Annual data, such as annual discharges of contaminants, are reported for CY 1993.

The objectives of this annual report are to

- summarize the results from environmental monitoring and data collection activities conducted during the past year by the WAG 2/SI Project and by other monitoring programs;

- report radionuclide flux and mass balance calculations for stream reaches between monitoring stations in White Oak Creek to gain more understanding of where radioactivity is accumulating or being mobilized in the system;

- describe recent advances in the fundamental understanding of hydrologic processes, whereby contaminants are mobilized and transported in surface and subsurface hydrologic systems; 
- provide assessment of both the monitored data and our knowledge of the contaminant transport processes to gain a reasoned perspective on the diversity, as well as the extent and movement of contaminants; and

- list the chemicals/radionuclides and the pathways that can potentially lead to unacceptable exposures to humans via surface water and groundwater transport.

The WAG 2/SI Project has developed a comprehensive, integrated approach to providing information to support ER efforts at ORNL. The work has been divided into four major activities (surface water, groundwater, soil and sediment, and biota). Information generated from these major activities, with data from other organizations, are used to assess the "contaminants of concern" and levels of risk at each of the ORNL WAGs.

Noteworthy is the result that ${ }^{90} \mathrm{Sr}$ has replaced ${ }^{3} \mathrm{H}$ as the main contributor to risk at White Oak Dam. This is due to an updated dose conversion factor for ${ }^{90} \mathrm{Sr}$ and the decline in annual ${ }^{3} \mathrm{H}$ discharge in part due to reduction in ${ }^{3} \mathrm{H}$ releases from ORNL. Risk in this document is based on the assumption of an individual ingesting water daily for 30 years. It is an indicator of water quality. To reduce the risk at White Oak Dam, due to ${ }^{90} \mathrm{Sr}$ releases, ER management has initiated early actions or interim remedial actions at seeps below WAG 5, a tributary below WAG 4, and the Corehole 8 plume in WAG 1.

\section{SURFACE WATER}

At the ORNL site, surface water is critically important because it transports contamination that has seeped to the land surface to off-site receptors. It also erodes and transports contaminated sediments, and deposits those sediments downstream, potentially causing exposures to people and biota. The ER purpose for analyzing surface water and the hydrologic cycle is to understand how contaminants move from sources to potential receptors.

In the WAG 2/SI Project, the surface water activities include a variety of data collection programs and focused investigations to determine the distribution, type, and discharge rates of contamination that moves through the ORNL drainage system. Results from the Seep Task and the Tributary Assessment Task support site-wide prioritization efforts and the groundwater operable unit investigations. Precipitation and stream discharge data support the modeling component of the Sediment Transport Task and engineering design of remedial actions. The data collection activities are aimed at the seep, tributary, and watershed scales.

During FY 1994 bimonthly sampling of seeps was initiated. In identifying seep sampling locations, greater focus was given to source areas of ${ }^{3} \mathrm{H}$ and ${ }^{90} \mathrm{Sr}$ because these two contaminants pose the greatest risk at White Oak Dam from water ingestion. Sampling transects in Melton Branch identified ${ }^{3} \mathrm{H}$ and ${ }^{90} \mathrm{Sr}$ sources, and two seep areas have been identified for removal actions to start in late FY 1994. Transect sampling in the WAG 4 tributary showed that ${ }^{3} \mathrm{H}$ and ${ }^{90} \mathrm{Sr}$ sources were not collocated. The data will be used in identifying a removal action for WAG 4. Contaminant flux estimates show that WAG 5 is currently the source of over half of the ${ }^{3} \mathrm{H}$ flux leaving the watershed. WAGs 4 and 6 are currently sources of ${ }^{3} \mathrm{H}$ primarily during the wet seasons. WAGs 1 and 5 are currently the main sources of ${ }^{90} \mathrm{Sr}$, with WAG 4 being the main contributor during the wet season. Within WAG 1 a significant portion also comes from First Creek, which is probably related to the Corehole 8 plume. 
Contaminant flux data from the main weirs are compared to reference levels. At Melton Branch Weir, White Oak Creek Weir, and White Oak Dam, elevated levels of sulfate, fluoride, and zinc were detected. In addition, at White Oak Dam elevated levels of chromium, aluminum, iron, manganese, total organic carbon, oil and grease, phosphorus, and total dissolved solids were detected. Melton Branch results are comparable with those at White Oak Dam, but metals are more like those found in the reference waters. With respect to organic contaminants, none found in Melton Branch exceeded the reporting level at the ambient monitoring stations.

The annual radiological contaminant fluxes from White Oak Dam for 1993 were $1800,2.1,0.53$, and $0.046 \mathrm{Ci}$ for ${ }^{3} \mathrm{H},{ }^{90} \mathrm{Sr},{ }^{137} \mathrm{Cs}$, and ${ }^{60} \mathrm{Co}$, respectively. The results are similar to those of the previous 3 years, although the total discharge of ${ }^{3} \mathrm{H}$ is slightly reduced from levels in 1991 and 1992. The distribution of contaminant sources within the watershed is revealed by extensive seep surveys.

The ORNL site conceptual hydrologic model was expanded to include an annual cycle in the flux of contaminants. In addition, detailed measurements of contaminant concentrations and stream discharge (C-Q) made during storms reveal distinctive patterns of contaminant dilution. Results also show that $C-Q$ relationships vary seasonally, with higher concentrations associated with wetter conditions and lower concentrations associated with drier conditions. Cumulative flux of contaminants over a 6-year period show a distinct annual cycle with the largest fluxes in the late fall-early winter time period when groundwater storage is filled and all precipitation is discharged as runoff. This conceptual model, combined with the monthly flow-proportional water quality monitoring, provides a basis for performance assessment of remedial actions at the watershed scale by the ER Program.

\section{GROUNDWATER}

During FY 1994, groundwater data collection activities at ORNL included ongoing sampling and analysis of wells at WAG perimeters; investigations related to the Remedial Investigation of WAG 5; well sampling, analysis, and water level data collection at WAG 1 under a post-Phase 1 Remedial Investigation monitoring activity; water level monitoring at wells throughout the ORNL site; and hydraulic head measurement at 13 Hydrostatic Head Measurement Stations. During FY 1994 a monitoring plan for the WAG 6 site was developed, and implementation of that monitoring will occur late in FY 1994 and will continue through FY 1995 and beyond.

Multiple wells at WAGs 4 and 5 have risks related to the ingestion of water in the range of $1 \times 10^{-4}$ to $1 \times 10^{-3}$, individual wells at WAGs $1,2,6,7$, and 17 have contaminant levels that could lead to carcinogen risk greater than $10^{-3}$, assuming a person used the well as the sole source of drinking water. WAGs 1 and 6 have numerous perimeter monitoring wells that have estimated risk on the order of $10^{-4}$. The highest levels of risk associated with groundwater contaminants are along the downgradient perimeters of WAGs 4 and 5.

Carcinogenic contaminants in groundwater at ORNL can be characterized as belonging to one of three categories: radiological contaminants, metals, or volatile organic compounds. Radiological contaminants, particularly total radioactive strontium (predominately ${ }^{90} \mathrm{Sr}$ ) and tritium, dominate the groundwater risk calculations at ORNL. Organic compounds contribute significantly to potential risk at some wells. Although computed risk levels at individual wells 
can be relatively large, the groundwater does not pose an unacceptable health hazard because the public does not have access to the groundwater resources, the wells generally cannot produce much water due to low permeability, and there are no known groundwater pathways off-site.

Modeling activities are currently addressing several groundwater-related issues that are important for the ER Program. Groundwater models have been used to estimate the groundwater flux leaving WAG 6, which is important to estimating the overall discharge of contaminants from the WAG. Modeling shows how the current impermeable caps to not ensure hydrologic isolation due to lateral shallow subsurface stormflow. Development of regional models using super computers and fracture-flow models that depict the complex mechanisms of transport expand our understanding of groundwater systems and our predictive capabilities. The Waterloo fracture-flow model will be applied to ${ }^{90} \mathrm{Sr}$ discharges associated with the Corehole 8 site in WAG 1.

Extensive laboratory experiments using tracers flowing through undisturbed cores of weathered shale have confirmed basic elements of the conceptual hydrologic model. Preferential flow in macropores combined with the effects of matrix diffusion have been demonstrated and quantified. These mechanisms that affect the movement of contaminants are important to the performance of remedial actions. If only primary sources (waste burial trenches) are remediated then secondary sources that are not remediated may release contaminants to streams for years, even decades. These mechanisms are currently being investigated at the field scale at the Seep A area below WAG 5. This work is being concurrently modeled with an innovative fracture-flow model developed at the University of Waterloo. These investigations will yield more realistic and reliable groundwater models in the future and better information for ER decision and for remedial action designs.

\section{SOILS AND SEDIMENTS}

Sediment transport sampling during floods provides a watershed-wide picture of the movement of suspended sediment and ${ }^{137} \mathrm{Cs}$, the major particle-bound contaminant. During flood conditions suspended sediments are intensively monitored via a network of automatic samplers. The data will be used to identify and quantify the processes of sediment mobilization and transport and to calibrate a computer simulation model. Results from a storm that occurred in December 1993 are summarized. The storm was estimated to have a 5-year return period but it resulted in less ${ }^{137} \mathrm{Cs}$ discharge at White Oak Dam than a 2-year storm that occurred earlier in the year. The pattern of transport of coarse- and fine-grained material through the channel system has been documented.

A walk-over radiation survey conducted in 1992 indicated that gamma radiation on the floodplain decreases in the direction away from White Oak Creek, presumably due to decreased deposition of ${ }^{137} \mathrm{Cs}$-laden sediments. The initial soil coring data confirmed this trend. More sampling will be conducted to identify other contaminants in addition to ${ }^{137} \mathrm{Cs}$ and to update the inventories of ${ }^{137} \mathrm{Cs}$ in the WAG 2 sources identified in the sediment transport conceptual model.

Stream bank erosion data have been collected and a preliminary analysis shows a clear trend of increasing bank erosion along White Oak Creek where the creek enters the wide floodplain area above White Oak Lake. The erosion rate for stream-bank sites upstream and downstream of the Intermediate Holding Pond (a heavily contaminated area) is $3.3 \mathrm{~cm} / \mathrm{storm}$ 
although further work is needed to generate erosion estimates for the channel network from these measurements.

\section{BIOTA}

Biological monitoring activities for the ER Program are conducted by the Biological Monitoring and Abatement Program, which also conducts data collection as required by the National Pollutant Discharge Elimination System Permit for ORNL. ER monitoring activities include documentation of ecological impacts of past and current operations and the identification of contaminant sources that may adversely affect stream biota in White Oak Creek, its tributaries, and White Oak Lake. The ER Program sponsors the assessment of contaminants in terrestrial biota and radioecology studies of White Oak Lake.

In 1993, for the second consecutive year, the ambient tests based on standard EPA procedures revealed no evidence of toxicity at any of the 15 stations. An experimental toxicity test, under development at ORNL using Medaka fish embryos, did indicate toxicity in White Oak Creek in the main plant area and downstream. The cause of this toxicity is uncertain.

Periphyton studies suggest some impact downstream of the plant because biomass was greater than reference levels but the role of contamination is uncertain. Redbreast sunfish populations in White Oak Creek are lower than reference levels but increasing yearly. Water and foam samples showed that there are some lipids, polychlorinated biphenyls (PCBs) and perhaps some petroleum products in the streams.

Analysis of fish in White Oak Creek show elevated levels of mercury and PCBs. Largemouth bass have elevated ${ }^{137} \mathrm{Cs}$, raccoons have elevated $\mathrm{PCBs}$ and ${ }^{137} \mathrm{Cs}$, and aquatic vegetation contain ${ }^{137} \mathrm{Cs}$ and ${ }^{60} \mathrm{Co}$ could be transferred to migratory waterfowl. Kingfisher remains contained measurable cadmium and mercury. The data indicate that wildlife are acquiring contamination on the ORNL site and that livestock watered on the site probably would also.

Biota monitoring results generally show a highly impacted, relatively stable ecosystem. The aquatic ecosystem, in some places, is improving, mostly because of reductions in pointsource discharges. Monitoring within the Biological Monitoring and Abatement Program, ecological risk assessment at the contaminant-source WAGs, and assessment and long-term monitoring in WAG 2 will continue to provide the biological information needed by ER Program decision makers for assessing remedial action alternatives.

\section{CONTAMINANTS OF CONCERN AND RISK ASSESSMENT}

The ORNL site has been divided into source-control operable units (waste area groupings or WAGs with buried wastes and leak sites) and integrator operable units (surface water system, WAG 2, and the ORNL Groundwater Operable Unit) which combine or integrate contaminant releases from source-control operable units. The division is based on the recognition that source-control WAGs should be remediated prior to cleaning up the integrator WAGs. Further, data gathered in the integrator units support decision making and risk assessment to prioritize the WAGs for remedial actions. 
For purposes of prioritizing remedial actions at ORNL, a simple scenario of ingestion of surface water is assumed. This approach is used to identify the contaminants in surface water, seeps, and groundwater that could contribute to unacceptable risk to human health. The exposure scenario is evaluated at several surface water monitoring locations within the watershed and at the surface water discharge point (White Oak Dam), although the public has no direct access to the White Oak Creek watershed. Based on available data, results show that contaminants in water exceed the EPA target risk goal (i.e., $1 \times 10^{-4}$ ) at various locations within the White Oak Creek watershed. The potential surface water risk at White Oak Dam $\left(6 \times 10^{-4}\right)$, a monitored location that integrates contaminants released from the source-control operable units just before entering the Clinch River, also exceeds the target level. The risk from these hydrologic discharges is derived almost entirely from radionuclides and not from organic compounds or metals.

The primary mobile contaminants in the surface water are ${ }^{3} \mathrm{H}$ and ${ }^{90} \mathrm{Sr}$ and, to a much lesser extent, ${ }^{137} \mathrm{Cs}$ and ${ }^{60} \mathrm{Co}$. This relative risk ranking at White Oak Dam is used to prioritize the contributions of source-control operable units to surface water. Further downstream, the dilution of the Clinch River reduces the risk below the action level for the maximally exposed individual at Clinch River at the closest downstream public-access point where land-based activities can occur (e.g., growing irrigated crops). All locations in the White Oak Creek watershed where calculated risks exceed the target risk goal have regulated access and extensive administrative controls to protect workers. Human health risk assessment is used not to document current risks, but to examine how contaminated locations relate to preliminary risk-based cleanup levels.

Ecological risk assessment to support ER decision making is currently under development. Several conceptual models for ecological risk assessment are presented and discussed. Recent agreements with regulators have provided for a multilevel approach to assessment. Ecological risk assessments are conducted at multiple scales starting at the sourcecontrol operable units and extending to the aquatic and terrestrial integrator operable units. Source operable units contribute most of the inputs to integrator operable units and data collected during source investigations will support future integrator assessments. Implementation of a Terrestrial Integrator Work Plan and development of a source-tointegrator conceptual model will provide a framework for assuring data compatibility. Efforts to develop ecological data quality objectives will also assure a more standardized, integrated, and efficient approach to ecological risk assessment at ORNL. The WAG 2 Remedial Investigation project will complete an interim baseline ecological risk assessment in early FY 1996.

\section{ADDITIONAL DATA NEEDS AND UPCOMING EFFORTS}

At the Data Quality Objectives workshop held in June 1994, WAG 2/SI project leaders, DOE representatives, and regulators agreed that the Phase I of the WAG 2 remedial investigation will be completed in FY 1995, in keeping with the original remedial investigation plan, and that the monitoring component identified as Phase II should start up. The purposes of Phase I were initial characterization, screening risk assessment, and identification of any need for an early remedial action or corrective measure. The remaining work in the Phase I Remedial Investigation will determine if any early actions are needed in WAG 2 to prevent unacceptable risks off-site and if there is any unacceptable ecological risk on the WAG. The two main tasks for the coming year are (1) to complete the HSPF computer simulation assessment of possible unacceptable off-site risk due to mobilization and transport of 
contaminated sediments currently deposited in WAG 2 and (2) to initiate data collection to support the biological assessment at WAG 2. Long-term monitoring to be considered for Phase II of the WAG 2 remedial investigation also relate to sediment transport and ecological risk. Field activities in support of these two tasks have not yet been defined in June 1994.

ORNL ER management had identified the need for a groundwater area-wide program and a surface water area-wide program. The groundwater component was begun in early FY 1994. The surface water program plan will be developed late in FY 1994 for start-up in the following fiscal year after DOE review and approval. These programs will emphasize assessment activities to answer specific ORNL ER issues and data collection to support the needed assessments. The surface water program will also include all biological monitoring needed to support ORNL ecological risk assessment at all scales. 


\title{
1. INTRODUCTION
}

\author{
R. B. Clapp, M. A. S. Guth, S. E. Herbes, and J. A. Watts
}

Oak Ridge National Laboratory (ORNL), located on the U.S. Department of Energy's (DOE's) Oak Ridge Reservation in eastern Tennessee, is a multidisciplinary research facility managed by Martin Marietta Energy Systems, Inc. (Energy Systems) for DOE. The Oak Ridge site was established in 1943, and 49 years of operations have produced a diverse legacy of contaminated inactive facilities, research areas, and waste disposal areas that are potential candidates for remedial action. The Oak Ridge Reservation was added to the National Priorities List in December 1989. A Federal Facility Agreement between DOE, the U.S. Environmental Protection Agency Region IV, and the Tennessee Department of Environment and Conservation coordinates remedial response actions. To bring the facilities into compliance with applicable federal, state, and local requirements for environmental restoration, a series of corrective activities have been identified and prioritized at ORNL (DOE 1992a).

The ORNL Environmental Restoration (ER) Program was established (1) to coordinate DOE's response obligations to the Comprehensive Environmental Response, Compensation, and Liability Act (CERCLA), the Resource Conservation and Recovery Act (RCRA), and other relevant regulations and (2) to manage the efforts to achieve comprehensive remediation of releases and threatened releases of hazardous substances, hazardous wastes, pollutants, or contaminants at or from ORNL. The ER Program follows a structured path of site characterization, site maintenance and surveillance, interim corrective action, alternative assessment, technology development, engineering design, and eventual site closure or remediation.

The ER Program supports numerous environmental monitoring and data collection activities. This report summarizes environmental data collected by the ORNL ER Program and by other groups at ORNL and presents assessments of those data. This report is prepared as part of the Environmental Restoration Monitoring and Assessment activity within the WAG 2/Site Investigation (SI) Project. This project and its objectives are described in detail later in this section. The Waste Area Grouping (WAG) 2/Site Investigation (SI) Program is a structured, multidisciplinary effort that is focused on collecting and assessing environmental information that will lead to an orderly, environmentally sound, and cost-effective remediation of contaminated sites at ORNL.

The Annual Environmental Restoration Monitoring and Assessment (ERMA) Report is generated to meet the following general goals:

- to provide an annual summary of environmental data, collected by the WAG 2/SI Project and other organizations, that are used by the ORNL ER Program;

- to assess the data in terms of risk to human health and the environment because the prioritization of remedial actions and the selection of remedial technologies for site cleanup are primarily driven by risk reduction; and 
- to inform the public, the regulators, and DOE managers about current environmental conditions and associated risks at the ORNL facilities managed by the ORNL ER Program.

The ERMA report strives to provide an ORNL site-wide perspective on types, distribution, and transport of contamination. Reports for investigations at individual waste disposal areas provide the detailed information on local contamination levels. This report supplements the first and second annual ERMA reports $(1992 ; 1993)$ and summarizes information gathered from March 1993 through March 1994. Selected summary data, such as annual discharges of contaminants, are reported for CY 1993.

To aid the reader, each chapter contains a brief outline, as shown here for Chapter 1.

\section{Chapter Outline}

Section 1.1 describes the ORNL site.

Section 1.2 describes the site-wide approach for environmental monitoring developed to support the ORNL ER Program, including the objectives and components of the WAG 2/SI Project.

Section 1.3 summarizes general activities ongoing in the ORNL WAGs through the middle of CY 1994.

Section 1.4 reviews the key aspects of the hydrology of the ORNL site that mobilize and transport contaminants within the watershed.

\subsection{ORNL SITE}

Because of the large number of contaminated sites and the hydrologic complexity at ORNL, the WAGs were developed to respond to regulatory requirements using a manageable approach are shown in Fig. 1.1. The WAGs are generally defined by small watersheds that contain contiguous and similar waste sites. In some cases, hydrologic interaction has occurred among the sites within a WAG, making individual sites hydrologically inseparable. The use of groupings allows perimeter monitoring of both groundwater and surface water and the development of a response that is protective of human health and environment. Twenty-one WAGs have been identified at ORNL, 14 of which are definite candidates for further action. With the exception of WAG 2 and the groundwater operable unit (WAG 21), these WAGs are sources of contaminants to other areas and have been termed "contaminant source WAGs." Characterization of the source WAGs will identify small operable units that will be prioritized for remediation and clean up accordingly.

WAG 2 consists of White Oak Creek below the 7500 bridge monitoring station, Melton Branch and associated floodplains, White Oak Lake, and the White Oak Creek Embayment at the confluence of the Clinch River. WAG 2 is downgradient from the contaminant source WAGs. Nine WAGs drain to the White Oak Creek and WAG 2: 


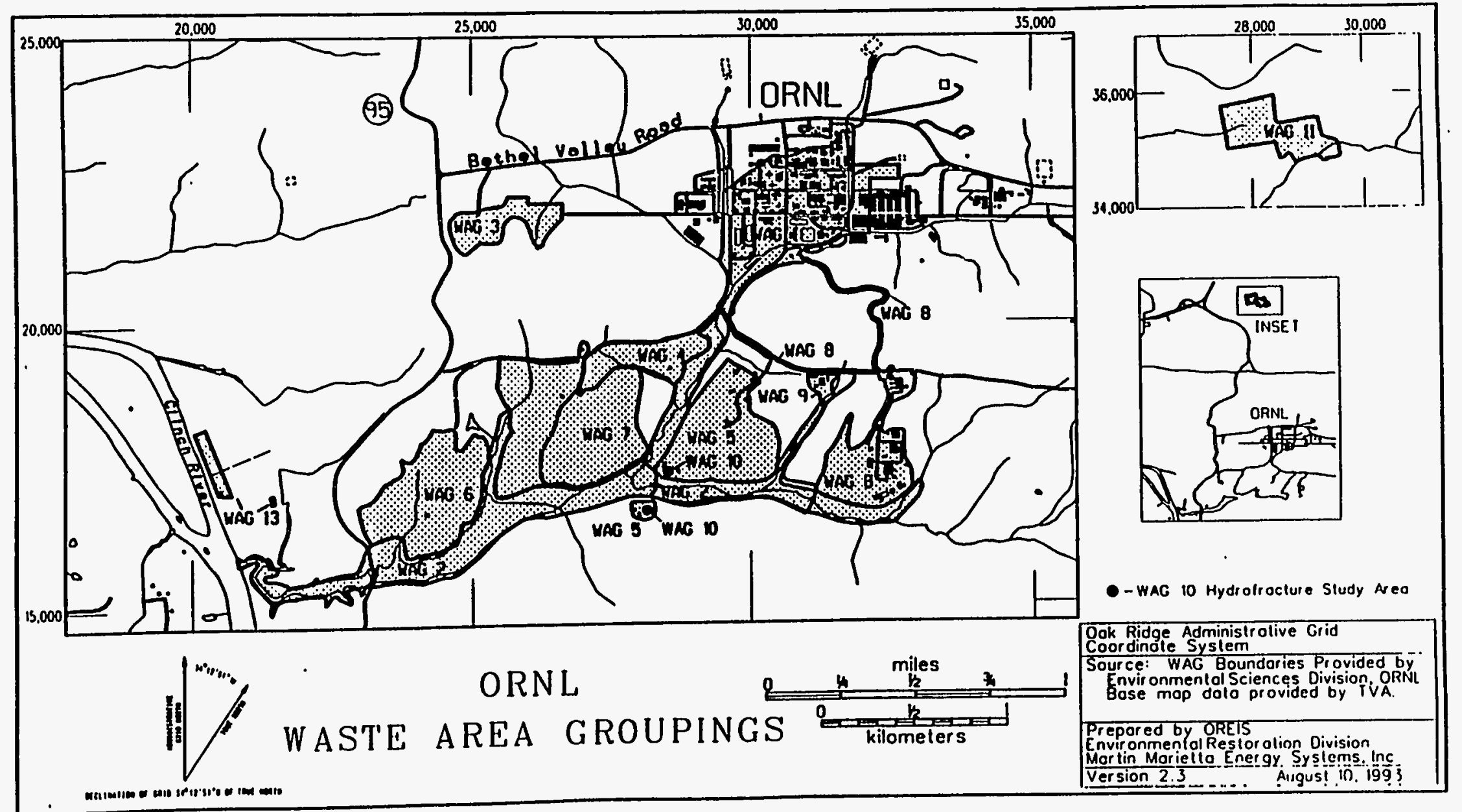

$\dot{\omega}$

Fig. 1.1. Map showing ORNL waste area groupings. 
WAG 1

the main plant area,

WAG 3, 4, 5, and 6 former waste disposal facilities called solid waste storage areas (SWSAs),

WAG 7

the former "Pits and Trenches" liquid waste disposal area,

WAG 8

the High Flux Isotope Reactor and associated transfer lines and disposal facilities,

WAG 9

WAG 17

the Homogeneous Test Reactor,

ORNL service areas.

WAG 10 is the deep Hydrofracture Waste Disposal facility, and although there are wellheads in WAG 2 and WAG 5, the disposed waste is associated predominately with very deep geological units.

WAG 2 is downgradient from all the WAGs in the watershed; therefore, it receives and integrates the contaminants released from the other WAGs in the watershed that move through the surface water system. Consequently, WAG 2 is termed an "integrator" WAG, and it serves as a conduit for contaminants from the ORNL WAGs to off-site areas.

The ORNL groundwater operable unit is shown in Fig. 1.2. It encompasses the groundwater beneath the ORNL site, and it is divided into two component operable units (Bethel Valley operable unit and Melton Valley operable unit). The groundwater operable unit is identified as a discrete entity because contaminants can migrate in the subsurface from one component operable unit to another. The groundwater operable unit is also an "integrator" unit because it receives the contaminants from the source WAGs that move through the groundwater system.

\subsection{SITE-WIDE, INTEGRATED APPROACH TO ENVIRONMENTAL MONITORING}

Early in FY 1992, two large-scale ORNL ER projects (the WAG 2 Remedial Investigation and the SI Program) were merged to better achieve their complementary objectives. The resulting WAG 2/SI Project consists of the remedial investigation/feasibility study for WAG 2, a long-term monitoring effort for the White Oak Creek watershed, and a series of directed monitoring efforts and investigations that identify and quantify the pathways and processes important for contaminant movement from ORNL WAGs within the White Oak Creek watershed. The White Oak Creek system is the surface drainage for the major ORNL WAGs and has been exposed to a diverse array of contaminants from operations and waste disposal activities in the White Oak Creek watershed. WAG 2 acts as a conduit through which hydrologic fluxes carry contaminants from upgradient areas to the Clinch River. Water, sediment, soil, and biota in WAG 2 are contaminated and continue to receive contaminants from upgradient WAGs.

The SI activities are a series of monitoring efforts and directed investigations that support ER activities by providing information for (1) watershed hydrology; (2) contaminants, pathways, and fluxes for groundwater at the ORNL site; (3) hydrologic pathways and fluxes that move contaminants through shallow depths and create secondary sources of contaminants; (4) biotic populations and contaminants in the biota; and (5) other support and coordination activities. These efforts fill the gaps in existing monitoring programs and provide information at the watershed-level that is needed to effectively conduct remedial investigation/feasibility study activities for the ORNL WAGs. 


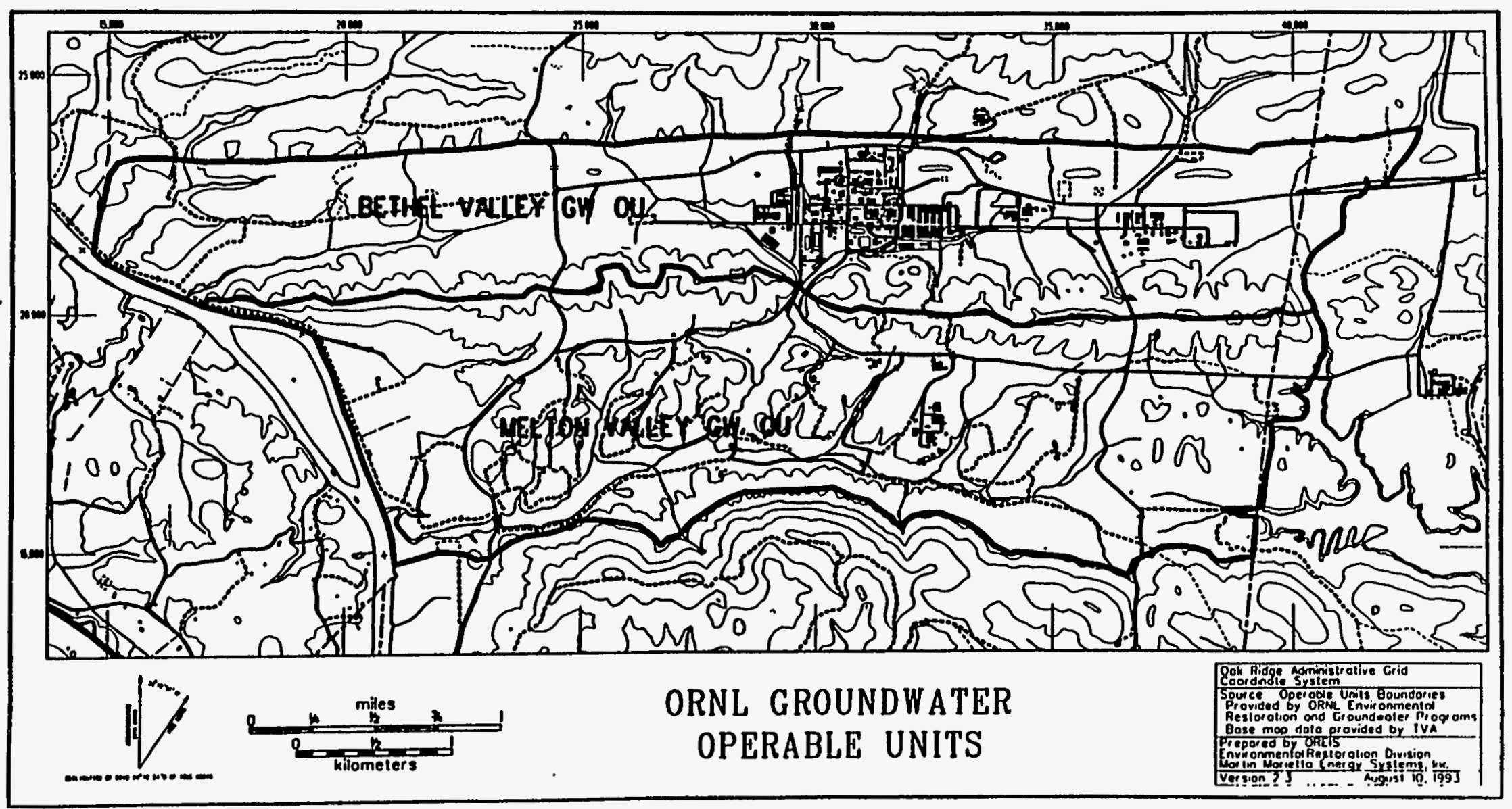

Fig. 1.2 Map showing the ORNL GW OU, which is divided into Bethel Valley and Melton Valley units 
The WAG 2/SI Project has been a key component of the ORNL operable unit strategy, wherein WAG 2 and the groundwater operable unit have been termed "integrator" units because they receive and integrate contaminant inputs from numerous source WAGs. WAG 2 links the ORNL surface waters, which are the primary pathway for contaminant fluxes from the ORNL WAGs to the Clinch River (off-site). The subtasks of the WAG 2/SI Project take advantage of the integrating role of WAG 2 to guide, support, and evaluate the ER Program's activities for the major source WAGs at ORNL, leading to the eventual remediation of WAG 2.

The designation of "contaminant-source" and "integrator" is critical to understanding the systematic approach to environmental cleanup at ORNL. The basic ORNL ER strategy for prioritization of remedial actions and allocation of resources is to address the cleanup of contaminated sites in an orderly fashion after ensuring that all on-site risks to workers and other potentially exposed individuals are minimized. Next, the source WAGs or operable units generating the largest proportion of off-site risk will generally be remediated first to reduce off-site flux of contamination, thereby reducing the potential hazards to the public. After contaminant source WAGs are controlled, then the integrator WAGs (WAG 2 and the groundwater operable unit) will be remediated, although it may be decades before final remediations to the integrator WAGs are completed. In the meantime, early actions and interim corrective actions will be initiated to reduce off-site flux of contaminants using the same risk-based prioritization approach used for identifying WAG remediations.

\subsubsection{WAG 2/SI Project Objectives}

Since its inception in FY 1992, the WAG 2/SI Project has served a key integrator role in monitoring and assessment activities for the ORNL ER Program. The continued input of contaminants to WAG 2 from upgradient areas and the role of WAG 2 as an integrator of contaminant fluxes have resulted in the formulation of a strategy that focuses on the following four key goals while upgradient WAGs are being remediated:

1. implement long-term monitoring and tracking of contaminants leaving other WAGs, entering WAG 2, and being transported off-site;

2. provide a conceptual framework to integrate and develop information at the watershed level for pathways and processes that are key to contaminant movement and so support remedial efforts at ORNL;

3. assess continually the risk (both human health and ecological) associated with contaminants accumulating in and moving through WAG 2 to off-site areas; and

4. support the ER prioritization and evaluation of remedial actions for ORNL WAGs through continued monitoring and risk assessment.

The objectives of the multimedia environmental monitoring program are to provde a consolidated basis of support for the ORNL ER Program office through the following:

1. collecting data and using data from ongoing programs (e.g., DOE-order-driven Environmental Surveillance monitoring) to develop a reach-by-reach mass balance for contaminants to determine contaminant releases from each ORNL WAG and to provide 
a record of contaminant release from the watershed (Data are being collected for storm conditions because much of the contaminant flux occurs during storms.);

2. estimating risk to off-site areas from individual WAGs (based upon contaminant fluxes) and supporting efforts to prioritize remedial activities;

3. supporting remedial actions for source units by (a) investigating the pathways and process that are important for contaminant fluxes, (b) providing watershed-level information for processes that cannot adequately be addressed at the WAG level (e.g., ecological assessment and sediment transport), and (c) providing technical support;

4. providing information from long-term monitoring of environmental media and biota to evaluate the effectiveness of remedial actions at ORNL;

5. providing a link with the Clinch River Remedial Investigation to contribute to an integrated assessment of the effects of releases from DOE facilities; and

6. gathering information to support the eventual remediation of WAG 2.

Achieving these objectives will provide a site-wide, integrated analysis of contaminant movement in the White Oak Creek watershed and from WAGs outside the watershed to support ORNL ER activities.

To differentiate more clearly those activities that support ER Program management from those prescribed through Federal Facility Agreement implementation of CERCLA directives, in FY 1995 the WAG 2/SI Project will be divided into its component organizational elements. The WAG 2 remedial investigation will continue through the CERCLA steps defined in the remedial investigation plan for WAG 2 (ORNL 1990) toward the goal of eventual remediation of WAG 2. The SI tasks, in concert with other selected ER activities at the ORNL site, will be consolidated organizationally into the ORNL Surface Water Program and the Groundwater Program. These organizational changes will enable more effective technical integration and scoping of the data collection and interpretation activities that provide ORNL ER Program management with the information required to assess long-term trends in contaminant fluxes, to periodically reevaluate prioritization of source areas requiring corrective action, and to assess the effectiveness of remedial activities. These programs will also serve as integrative mechanisms for refinement of the site conceptual models, to assist in understanding potential impacts of remedial alternatives and in optimizing remedial designs.

\subsubsection{ERMA Strategy and Organization}

The ERMA activities are coordinated through the Technical Integration/ERMA task within the WAG 2/SI Project. It is anticipated that this integration function will be elevated to the ER Program level through the Program Technical Integration task in FY 1995 to facilitate rapid and effective use of assessment information in program level decision making. Figure 1.3 shows the major tasks of the WAG 2/SI Project.

ERMA activities include tasks within the WAG 2/SI Project as well as other ER tasks. Additional data are obtained from non-ER sources to ensure the most effective use of resources and to prevent duplication of effort. Work areas within the WAG 2/SI Project that contribute to ERMA include surface water, groundwater, soil and sediments, and biota. 
WAG 2/SI PROGRAM

ORNL.OWG 92M-8971R

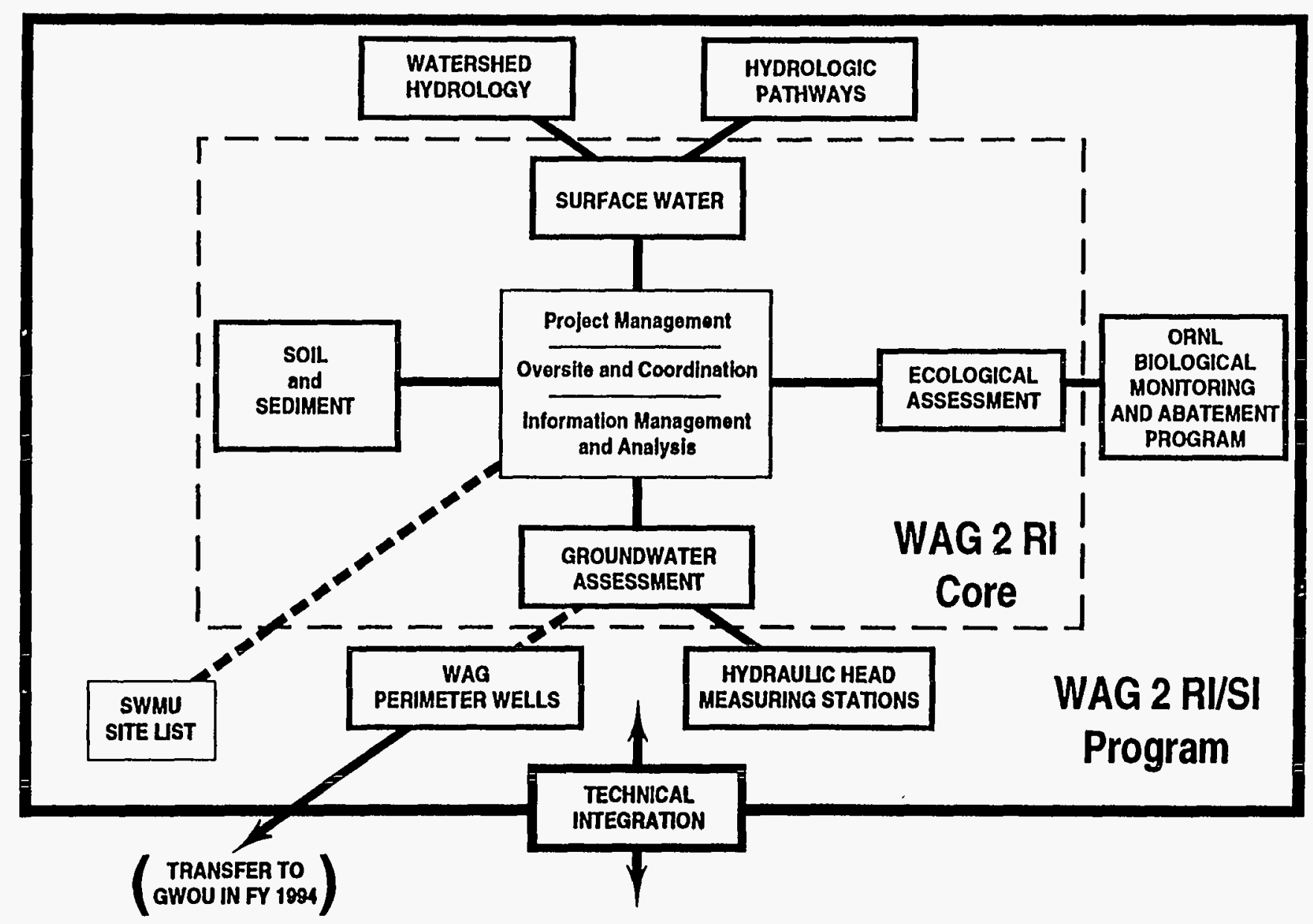

Fig. 1.3. Major tasks for the Waste Area Grouping 2/Site Investigation Project. Arrows indicate the flow of information. 
The Surface Water task includes four components.

- Surface Water Hydrology: Focusing on precipitation and surface water discharge monitoring to support a variety of ER projects.

- Seeps and Tributaries Survey: Identifying the spatial distribution of contamination in seeps and tributaries, interacting with surface water chemistry and groundwater tasks, and supporting remediation of contaminant sources.

- Tributary Assessment: Investigating the dynamic behavior of contaminant discharge from tributaries draining waste areas, important because the dynamic behavior describes hydrologic flow path and release mechanisms.

- Surface Water Chemistry: Using data for water chemistry collected at the major monitoring stations to support risk assessment and construct mass balances for contaminants.

The Groundwater Task has four components.

- Groundwater Monitoring and Data Assessment: Collecting data for metals, radionuclides, and organic contaminants from a series of 168 wells located on the perimeters of the ORNL WAGs, collecting water levels for the whole site, and analyzing the results for temporal and spatial trends.

- Directed Studies: Focusing on specific uncertainties in the groundwater system, including the Hydrostatic Head Monitoring Stations Task (collecting data for watershed exit pathways and exploring hydrologic communication between intermediate and shallow groundwater by monitoring well clusters).

- Hydrolic Pathways Investigation: Advancing the conceptual understanding of how contaminants are transported by groundwater at the ORNL site and developing mathematical models of transport mechanisms.

- Groundwater Modeling: Constructing a 3-dimensional model of groundwater flow to better support the selection and evaluation of remedial actions.

Note that the Groundwater Operable Unit Program was recently established. Most of the WAG 2/SI groundwater tasks were transitioned to the ORNL site-wide groundwater effort (groundwater operable unit) during the past year.

The Soil and Sediment Task has three components.

- Floodplain Soils and Aquatic Sediments: Determining the inventories of contaminants in floodplain and aquatic sediments to (a) identify contaminant sources areas, (b) support and integrate sediment management programs to minimize the potential for contaminant release to off-site areas, and (c) evaluate interim corrective measures and potential future remedial actions. 
- Storm Sediment Monitoring: Collecting samples of suspended sediment and associated particle-reactive contaminants during extreme storms in order to understand the movement of contaminants and to calibrate a computer model of water, sediment, and contaminant transport.

- Sediment Transport Modeling. Developing a calibrated computer model to predict the potential for the erosion and transport of sediment and particle-reactive contaminants following changes in the watershed (e.g., as a result of remedial actions) and during extreme storm events. This task was part of the Storm Sediment Monitoring Task during the previous fiscal year.

The Biota Task has two components.

- Ecological Assessment: (a) Coordinating efforts of an ORNL-wide biological monitoring program with efforts in individual WAGs to develop an integrated long-term monitoring program to measure impacts and document changes in biotic communities; (b) developing models of contaminant flow through the biota to identify organisms at risk; and (c) obtaining needed data not being collected by other programs to support the selection, implementation, and evaluation of remedial actions.

- ER-supported components of the ORNL Biological Monitoring and Abatement Program: (a) Ambient toxicity monitoring and effluent toxicity testing; (b) bioaccumulation studies; (c) biological indicator studies; (d) in-stream monitoring of invertebrates and fishes; (e) the radioecology of White Oak Lake; and (f) contaminants in terrestrial biota.

WAG 2/SI program support includes several activities:

- human health and ecological risk assessment for WAG 2 and risk-based prioritization of contaminant sources at ORNL;

- data management and quality assurance/quality control functions for all WAG 2/SI efforts;

- technical integration and coordination for WAG 2/SI efforts with other sampling, monitoring, evaluation, and assessment efforts in the White Oak Creek watershed; and

- other activities, including the preparation of the annual ERMA report.

The results from these tasks for the year (until about April 1994) are summarized in this document.

For each major task, internal and external organizations were identified for the exchange of data and information. The internal and external organizations include the following:

- National Pollution Discharge Elimination System-monitoring conducted by Environmental Surveillance and Protection Section with the ORNL Office of Environmental Compliance and Documentation.

- U.S. Geological Survey-subcontracted for streamflow monitoring, seep surveying, and hydrologic expertise. 
- Remedial investigation/Feasibility study subcontractors-Bechtel National, Inc., for WAGs 1, 5, and 10, and CDM Federal Programs Corporation and Science Applications International Corporation for WAGs 1 and 6.

Additional activities outside the WAG 2/SI Project that provide data to ERMA include:

- Biological Monitoring and Abatement Program-for the compliance component; the ERsupported component is a task within WAG 2/SI.

- Oak Ridge Reservation Hydrologic and Geologic Study-an ongoing integrated study of the hydrology, geology, and soils of the Oak Ridge Reservation in support of many groups, including the ER Program.

- Clinch River Remedial Investigation-the remedial investigation of surface water system downstream of White Oak Creek.

- Groundwater operable unit-ORNL site-wide ER groundwater investigations and remediation.

- Groundwater Protection Program-an ORNL site-wide groundwater activities coordination effort, including non-ER activities. Groundwater Protection Program Coordinator maintains documentation related to groundwater well status.

\subsubsection{Reporting}

The objectives of the annual ERMA report are to

- list the chemicals/radionuclides and the pathways that can potentially lead to unacceptable exposures to humans;

- summarize the results from environmental monitoring and data collection activities conducted during the past year by the WAG 2/SI Project and by other monitoring programs;

- report radionuclide flux and mass balance calculations for reaches in White Oak Creek to gain more understanding of where in the system radioactivity is accumulating or being mobilized;

- describe recent advances in the fundamental understanding of the hydrologic processes whereby contaminants are mobilized and transported in surface and subsurface hydrologic system;

- provide assessment of both the monitored data and our knowledge of the contaminant transport processes to gain a reasoned perspective on the extent and movement of contaminants; and

- describe future data collection and monitoring activities. 


\subsubsection{Data Quality}

Data and results summarized in Sects. 2 through 5 of this report were derived from several activities guided by different quality assurance plans. Data generated by the WAG 2/SI Project were collected in accordance with objectives described in the program Quality Assurance plan (Atwood and Miller 1992). The recent Phase I Remedial Investigation report for WAG 2 has detailed results of quality assurance determinations and data validation activities. Surface water and groundwater quality data summarized in Sects. 2 and 3 were collected and validated by the ORNL Office of Environmental Compliance and Documentation to conform to standards required for monitoring under National Pollutant Discharge Elimination System and DOE Order 5400.1. These data collection activities have had extensive audits and reviews. In Sect. 5 data collected within the compliance portion of the Biological Monitoring and Abatement Program conform to quality assurance standards identified in seven project level quality assurance plans focused on the different activities within Biological Monitoring and Abatement Program, and data collected for ER assessment purposes conform to WAG 2 specification (Atwood and Miller 1992).

\subsection{RECENT ACTIVITIES AT THE ORNL WAGS}

\subsubsection{Groundwater Operable Unit}

The ORNL groundwater operable unit focuses on deeper groundwater that may potentially remain deep and migrate off-site. Individual source WAGs include groundwater remediation plans and clean-up efforts focused on shallow groundwater pathways, where contaminant discharge points lie within the WAG or in streams adjacent to it. In contrast, the groundwater operable unit focuses on the intermediate and deep groundwater.

Activities in FY 1994 included submission of this operable unit's strategy document to U.S. Environmental Protection Agency and Tennessee Department of Environment and Conservation (DOE 1994a). Shallow groundwater is known to transport contaminants directly from sources to adjacent surface water bodies; however, the extent of deep groundwater contamination pathways needs more investigation. Data collection will focus on the depth and areal extent of contaminants migrating in groundwater between and beneath source WAGs and the potential for migration of hydrofracture-related contamination. To increase our knowledge of the conceptual model and flow system, data will be analyzed to determine (1) the potential for groundwater inflow or outflow beneath surface watershed divides, (2) the role of karst in providing contaminant routes, (3) the effects of subsurface retardation processes on long-term contaminant migration, (4) the depth of potential contaminant circulation and the long-term containment of hydrofracture contaminants at depth, and (5) define the groundwater exit points for the ORNL site. The groundwater assessment will provide data on the nature and extent of groundwater contamination, as well as tools for evaluating future potential risk to on-site and off-site groundwater users.

\subsubsection{WAG 1}

WAG 1 encompasses a large portion of the ORNL Main Plant Area and is shown in Fig. 1.4. Because WAG 1 is an active, multifunctional site with a large workforce, WAG 1 remediation will be technically and logistically complicated. WAG 1 has been divided into 10 operable units, and each operable unit has its own remediation schedule and process. 


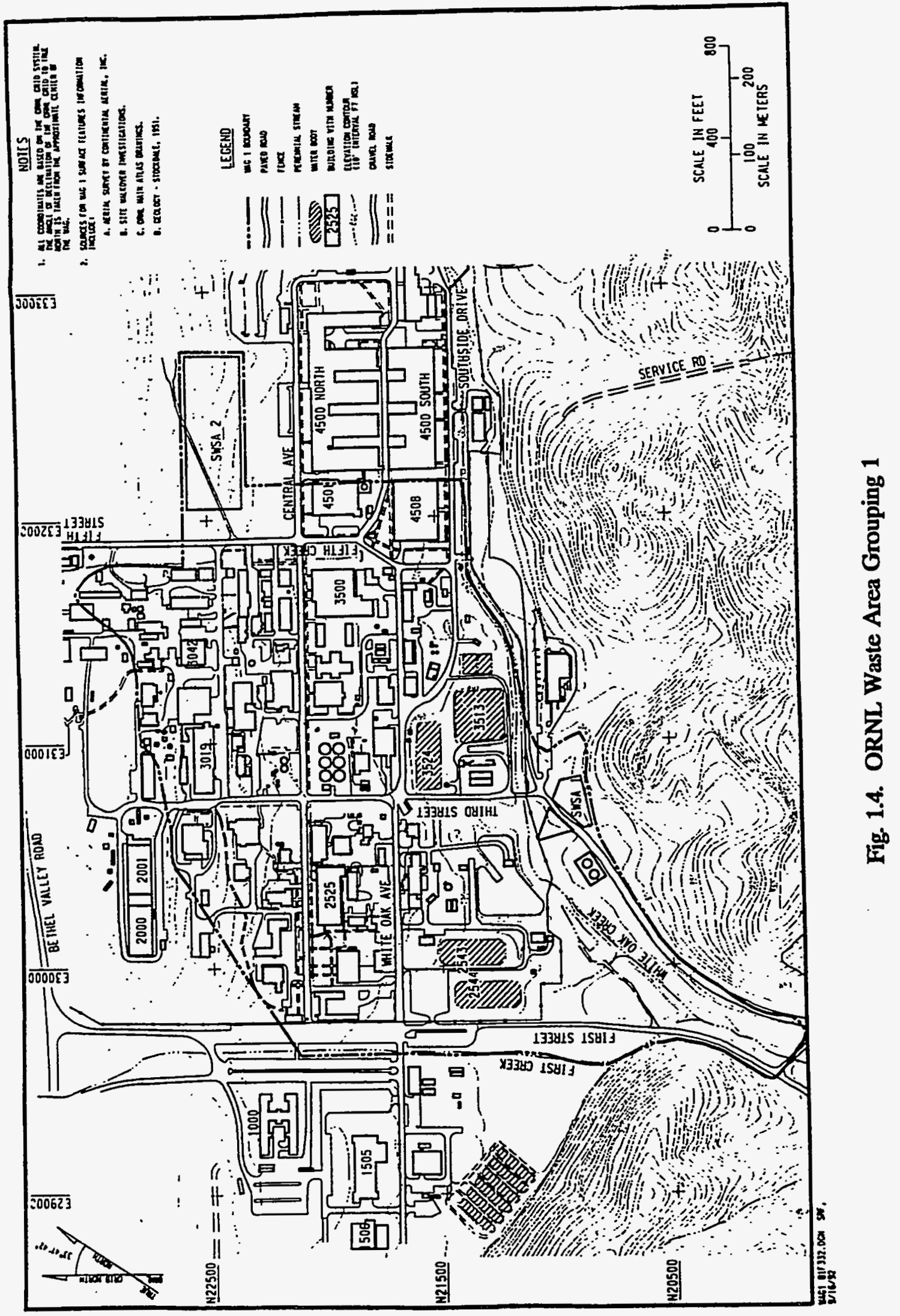


Remediation and/or removal actions are planned for the Gunite and Associated Tanks operable unit, the Surface Impoundments operable unit, and the Corehole 8 plume in the near future. Early actions are also planned for some of the tasks in the steel tanks operable unit. Final remediation of the groundwater operable unit, the Pipelines and Storm Drains operable unit, and White Oak Creek Sediment operable unit should be delayed until the other source and soil operable units have been remediated.

The report Remedial Investigation/Baseline Risk Assessment for the Gunite and Associated Tanks Operable Unit at Waste Area Grouping 1 at Oak Ridge National Laboratory, (DOE 1994b) was completed this fiscal year and sent to Tennessee Department of Environment and Conservation and U.S. Environmental Protection Agency for approval. The feasibility study has been separated from the Remedial Investigation/Baseline Risk Assessment so that it can include the results from treatability studies planned for FY 1995 through FY 1997. The Gunite and Associated Tanks operable unit team is scheduled to submit a draft treatability study plan to U.S. Environmental Protection Agency and Tennessee Department of Environment and Conservation in September 1994. The treatability studies will demonstrate three or more options for using sluicing technologies to remove the tank contents: (1) conventional sluicing with a nozzle, (2) using mixer pumps, and (3) using a manipulator arm. The feasibility study is now tentatively scheduled for completion in late FY 1997.

Remediation of the Surface Impoundments operable unit (Fig. 1.5) is being conducted under the Streamlined Approach for Environmental Restoration-one of only five such projects at DOE sites across the United States. This project is on a fast-track and receiving special DOE priority. Principal radionuclide contaminants are ${ }^{90} \mathrm{Sr},{ }^{137} \mathrm{Cs}$, and some ${ }^{3} \mathrm{H}$. The Remedial investigation/feasibility study, including the baseline risk assessment for the surface impoundments, is due to the U.S. Environmental Protection Agency and Tennessee Department of Environment and Conservation in February 1995. The data quality objective workshop for the Surface Impoundments operable unit was also completed in FY 1994.

Activities associated with the WAG 1 groundwater operable unit will include a long-term monitoring plan and an investigation of the source of the Corehole 8 plume. Work on this report continued in FY 1994, and the report should be completed in FY 1995. The work plan for conducting the characterization was published this fiscal year, Site Characterization for Groundwater in Waste Area Grouping 1 at Oak Ridge National Laboratory (Lee et al. 1994). This activity is being coordinated with the ORNL site-wide groundwater operable unit investigation.

Construction activities planned for FY 1995 at WAG 1 include a removal action for the Corehole 8 plume. The origin of the contamination is unknown at this time. The plume transports contaminants, mainly ${ }^{90} \mathrm{Sr}$, westward to First Creek via discrete groundwater flowpaths and seepage into ORNL storm drains. Seep data collected in First Creek indicates that this plume is a major source of ${ }^{90} \mathrm{Sr}$ to the White Oak Creek drainage. An Engineering Evaluation/Cost Assessment for this removal action will be completed in FY 1994 based on installation of interception trenches and collection sumps to be constructed in FY 1995.

\subsubsection{WAG 4}

WAG 4 includes the land containing and surrounding SWSA 4, the Pilot Pit area, and the transfer lines connecting the Pilot Pit area to SWSA 4. The major contaminants at the WAG include ${ }^{90} \mathrm{Sr},{ }^{3} \mathrm{H},{ }^{137} \mathrm{Cs}$, and a relatively small amount of ${ }^{60} \mathrm{Co}$. WAG 4 is a major 


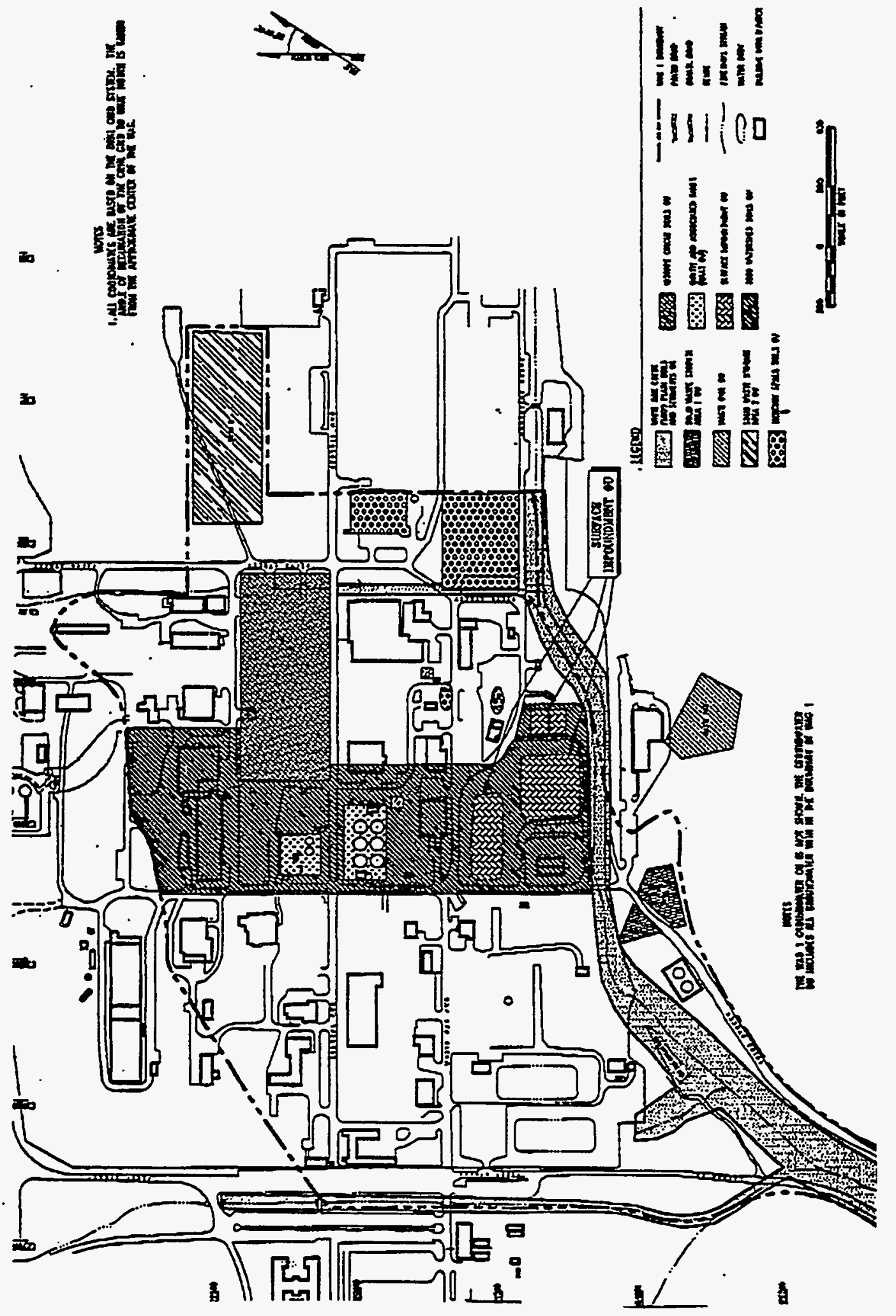

范 
contributor of ${ }^{90} \mathrm{Sr}$ and ${ }^{3} \mathrm{H}$ to White Oak Creek. Figure 1.6 illustrates WAG 4. Preliminary data are being collected to support the selection from among alternative early actions on ${ }^{90} \mathrm{Sr}$ seepage from saturated disposal trenches.

Measurements at seeps and tributaries in the vicinity of WAG 4 indicate that significant quantities of ${ }^{90} \mathrm{Sr}$ are discharged from this WAG to White Oak Creek. Strontium-90 discharge from the WAG constitutes about $18 \%$ of the ${ }^{90} \mathrm{Sr}$ discharge observed at White Oak Dam over the past 3 years, based on mass-balance data from ERMA $(1992,1993)$ and Table 2.3 this report. Moreover, about $40 \%$ of the ${ }^{90} \mathrm{Sr}$ discharge from the WAG can be attributed to seepage from three discrete areas associated with bathtubbing trenches. "Bathtubbing" refers to the subsurface filling of a waste trench during storms or elevated groundwater conditions, followed by the leaching of contaminants and seepage of those contaminants at the downgradient end of the trench.

During the past year, ER management initiated a project to significantly reduce the ${ }^{90} \mathrm{Sr}$ released from these seep areas in order to reduce off-site risk and contamination within the White Oak Creek system. After a review of historical data, investigations were conducted to confirm the WAG-specific conceptual model (i.e., the location and behavior of the bathtubbing trenches). The investigation included analysis of soil samples and installation of drive-point wells plus geophysical and ground-penetrating radar studies to locate the waste trenches. These activities will probably lead to an Interim Remedial Action to hydrologically isolate the bathtubbing trenches $\left({ }^{90} \mathrm{Sr}\right.$ sources) thereby reducing the contaminant discharges. Current planning includes the preparation of a proposed plan for interim remediation, an Interim Record of Decision, and initial design of the remedial action during FY 1995.

\subsubsection{WAG 5}

WAG 5 is composed of SWSA 5, one of the waste disposal sites at ORNL, and the land surrounding the SWSA. WAG 5 encompasses 80 acres, approximately 60 acres of which were used for waste disposal. SWSA 5 was opened in 1959 as SWSA 4 neared capacity; it is composed of two distinct geographical areas, referred to as SWSA 5 North and SWSA 5 South. SWSA 5 North was primarily used for the disposal of transuranic wastes. Prior to 1970, transuranic waste was buried in unlined trenches and auger holes. After 1970, transuranic wastes were required to be retrievably stored in special facilities. SWSA 5 South was primarily used for the storage of low-level radioactive waste (Fig. 1.7). However, an unknown quantity of transuranic waste was buried in trenches and auger holes in this area prior to the designation of SWSA 5 North as the Transuranic Waste Storage Area. WAG 5 also includes a trench and dump area that is not well defined, used for the disposal of segregated alphacontaminated waste that was buried in trenches and covered with a slab of concrete.

The WAG 5 field investigation to collect data that will be compiled for the Phase I Remedial Investigation report was completed in FY 1994. The annotated outline for the remedial investigation has been developed and the Remedial Investigation report is scheduled to be submitted to U.S. Environmental Protection Agency and Tennessee Department of Environment and Conservation in March 1995. An early removal action was included in FY 1994 to reduce the amount of ${ }^{90} \mathrm{Sr}$ leaving the WAG 5 site and crossing White Oak Dam. In-situ zeolite treatments have been designed for seep areas C and D. By November 1994, equipment will be installed to remove ${ }^{90} \mathrm{Sr}$ in Seeps $\mathrm{C}$ and D. This removal action is one of three Energy Systems proposals for a pilot test for a new streamlined way of addressing environmental concerns. The project will install a collection treatment system for 


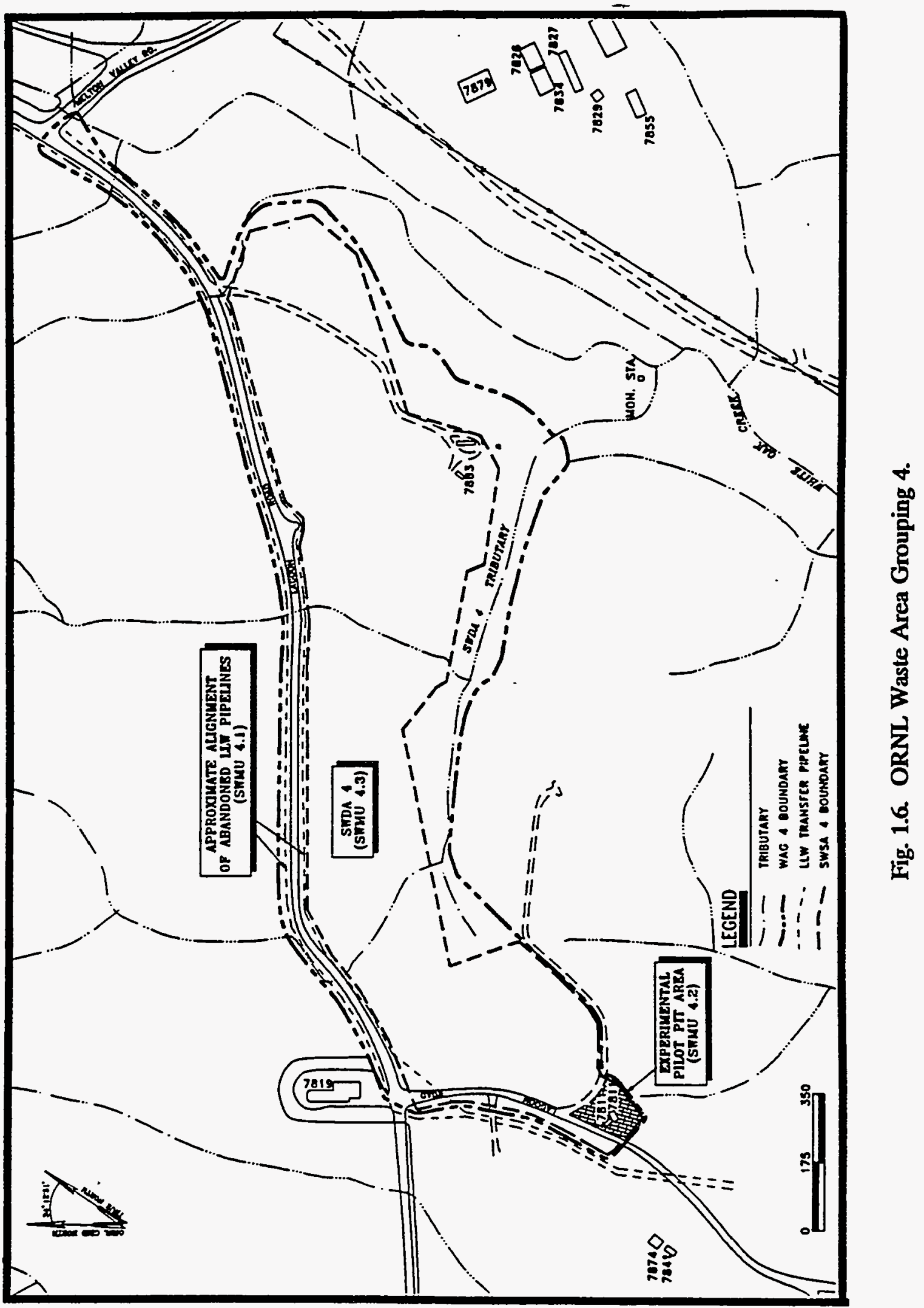




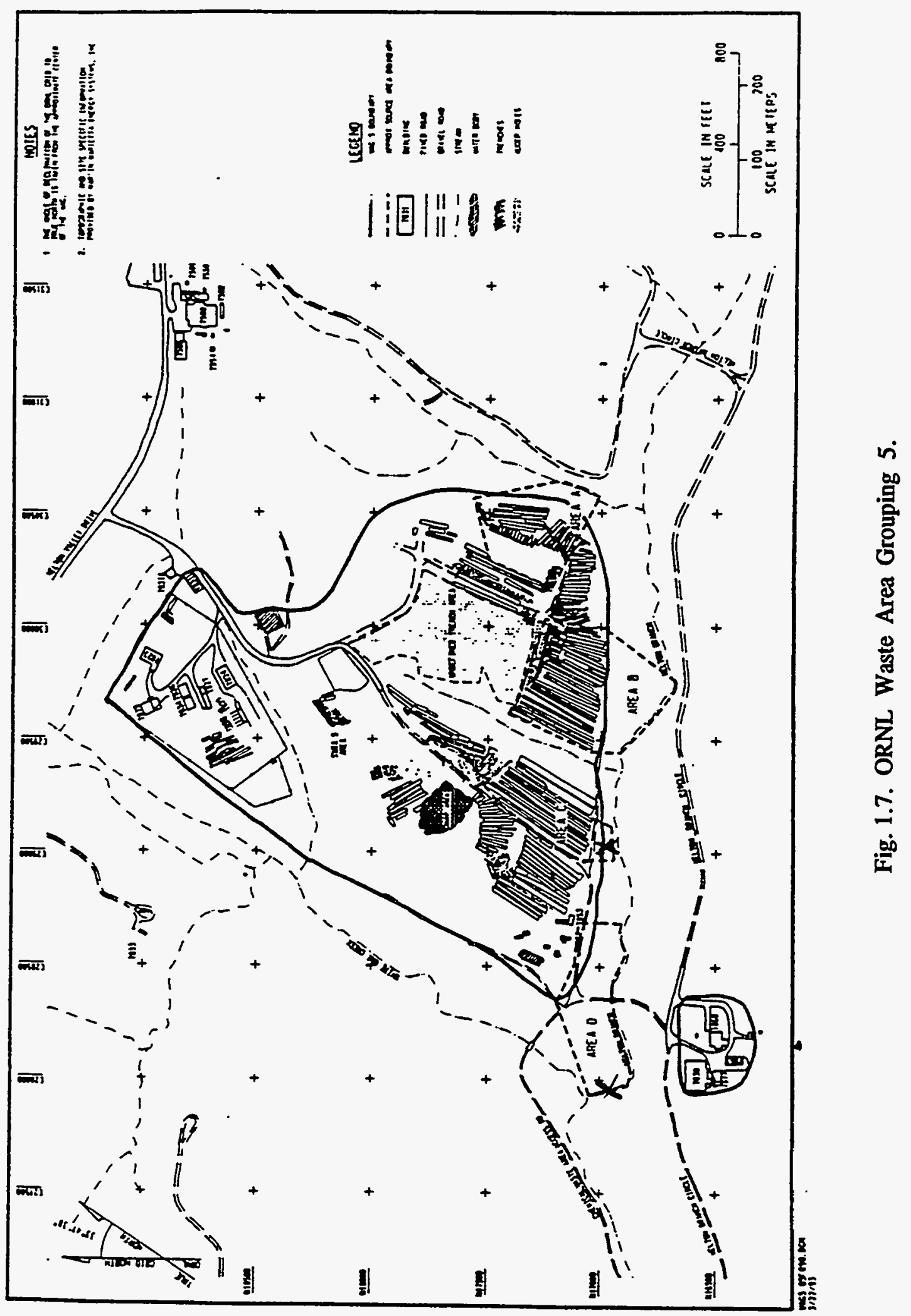


contaminated seep water. Currently, water seeps at a rate of approximately $750 \mathrm{gal} / \mathrm{day}$ or 0.5 $\mathrm{gal} / \mathrm{min}$. Seep $\mathrm{C}$ is believed to contribute approximately $25 \%$ of the ${ }^{90} \mathrm{Sr}$ found at White Oak Dam, and Seep D contributes $10 \%$ of the ${ }^{90} \mathrm{Sr}$ contamination.

Prior to FY 1995, a risk assessment analyzed separately five components of WAG 5: the Old Hydrofracture Facility Pond, the Process Waste Sludge Basin, SWSA 5, the transuranic waste area, and miscellaneous leak/spill sites. A post remedial investigation-monitoring activity will be initiated as part of the WAG 2/SI Project and the ORNL groundwater operable unit project to continue to track off-site migration.

\subsubsection{WAG 6}

WAG 6 comprises three Solid Waste Management Units: Solid Waste Storage Area 6, the Emergency Waste Basin, and the Explosives Detonation Trench. The Emergency Waste Basin is located adjacent to the northeast boundary of SWSA 6, and the Explosives Detonation Trench is located within the southeast portion of SWSA 6. WAG 6 is shown in Fig. 1.8.

SWSA 6 covers 68 acres, approximately 19 acres of which are used for waste disposal. It was opened for limited disposal operations in 1969, and began full-scale operation in 1973. It has received low-level radioactive waste and chemical, biological, and mixed wastes (e.g., solvents, scintillation liquids, laboratory glassware and equipment, and protective clothing). Over the period from 1986 to 1987 disposal technologies were vastly improved. Disposal in unlined trenches was replaced with containerized disposal, and waste acceptance criteria were implemented.

Following a public meeting on February 9, 1993, to review remedial alternatives in the proposed plan (DOE 1992), it was decided that construction of an extensive, temporary closure system for WAG 6 would be abandoned. The decision was based on the observation that risk to human health resulting from contaminant releases from WAG 6 constitute only about $2 \%$ of risk due to all the contaminants discharged at White Oak Dam. Currently, the WAG is judged to have low priority within the ORNL clean-up hierarchy. Instead of an interim remediation project, new programs for site monitoring and for development of innovative technologies to remove/isolate wastes were initiated. The need for remedial action at WAG 6 will be addressed at some point in the future.

During September 1993 the monitoring plan was issued (DOE 1993a) and collection of samples began in the spring. The main purpose of the monitoring program is to ensure that any significant changes in release of contaminants from WAG 6 do not go undetected. The strategy behind the WAG 6 monitoring plan (DOE 1993a) conforms to the ORNL-wide risk management approach described in Sect. 6. The WAG monitoring strategy builds on the fact that measured discharges of ${ }^{3} \mathrm{H}$ and ${ }^{90} \mathrm{Sr}$ leaving are relatively small compared with those measured elsewhere in the basin, via four water flow pathways shown in the "funnel diagram" in Fig. 1.9. The monitoring is designed so that the total annual contaminant discharge can be estimated from flow paths at gaged surface water sites, along the ungaged perimeter, and from the shallow and deep groundwater systems as shown in the WAG 6 site funnel diagram in Fig. 1.10. Future annual assessments of WAG 6 will be based on successive annual monitoring results. Resources are directed to flow paths (such as surface water) where the largest contaminant releases occur. 


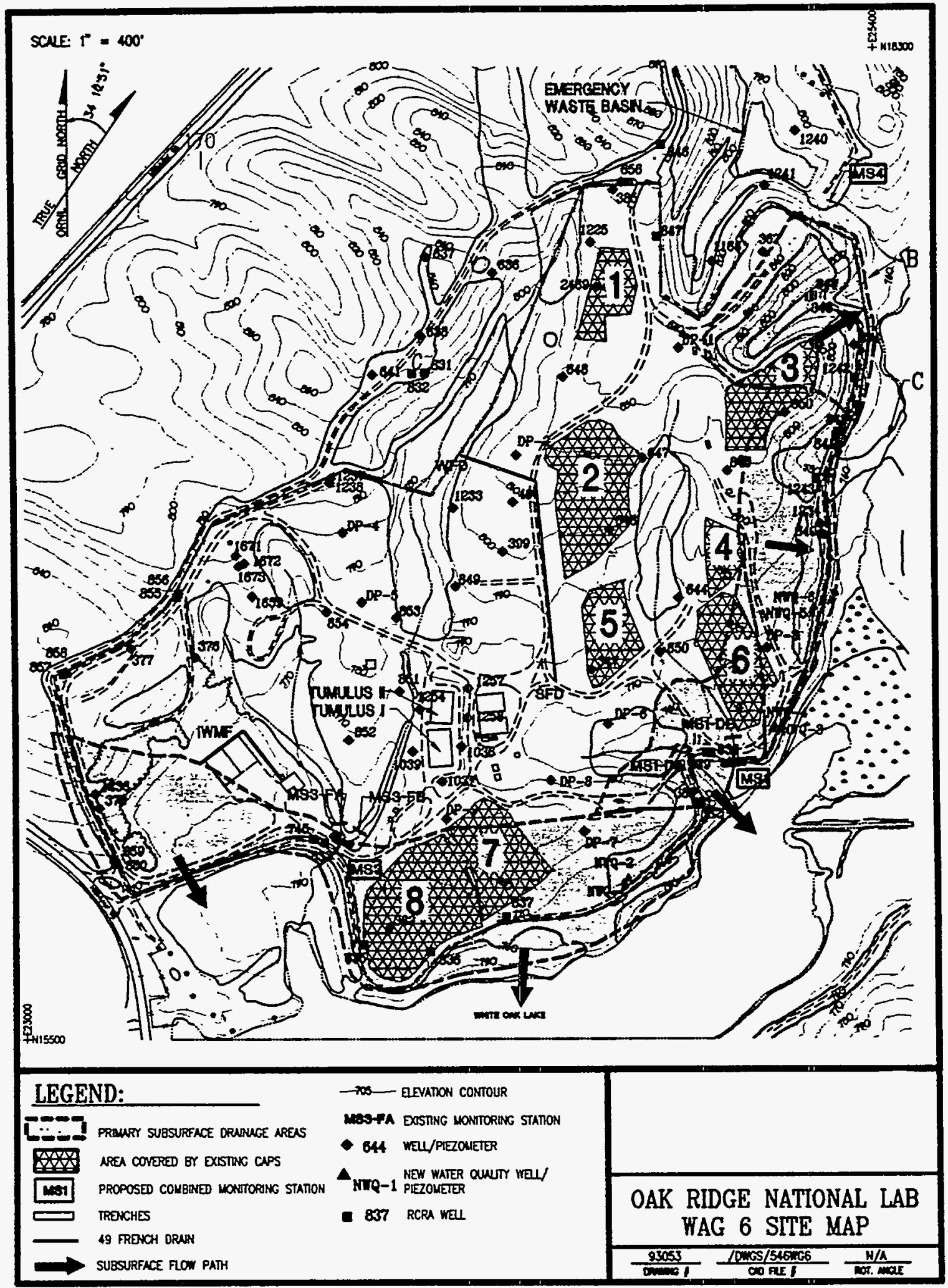

Fig. 1.8. ORNL Waste Area Grouping 6 


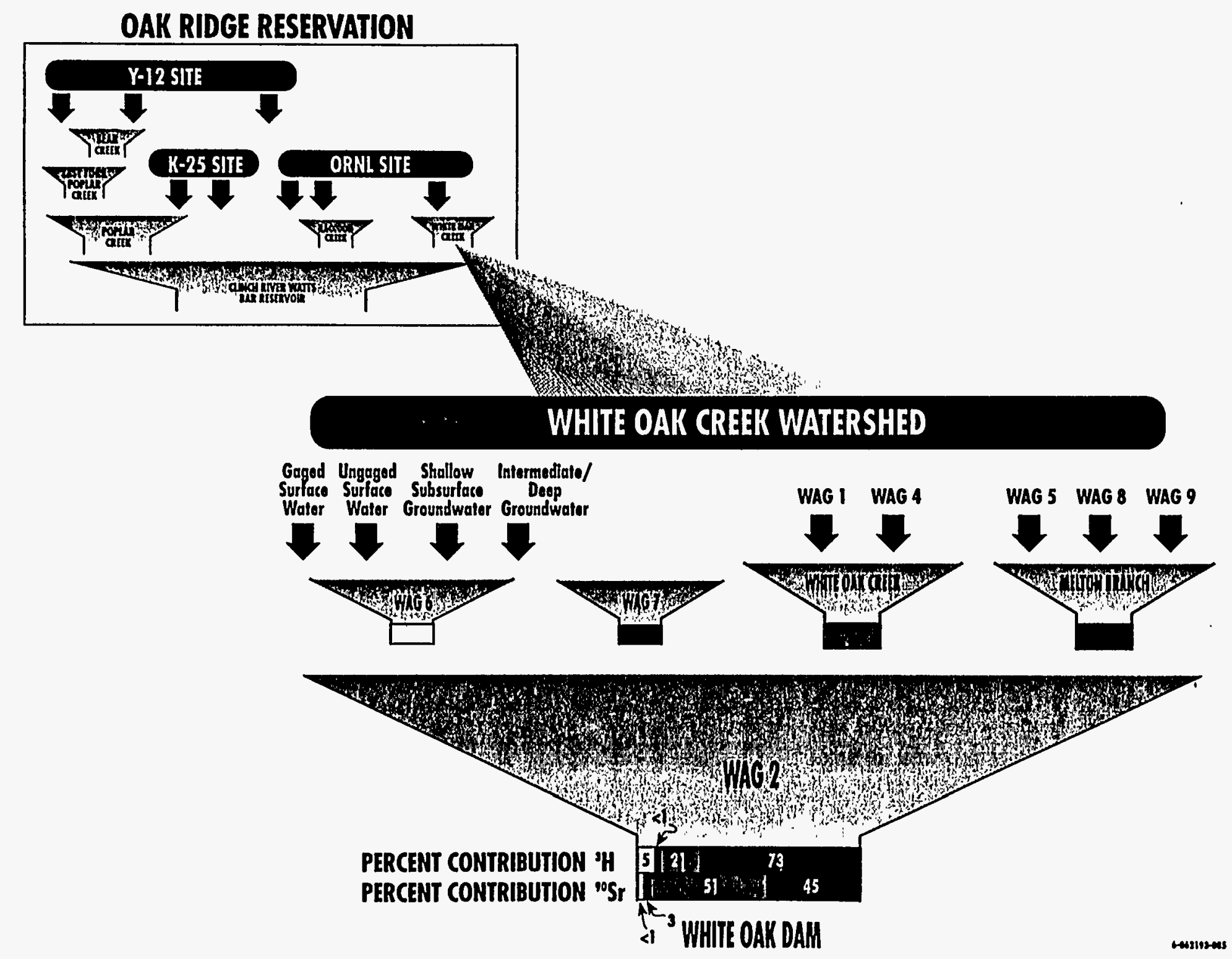

Fig. 1.9. Contaminant discharge to White Oak Dam. 


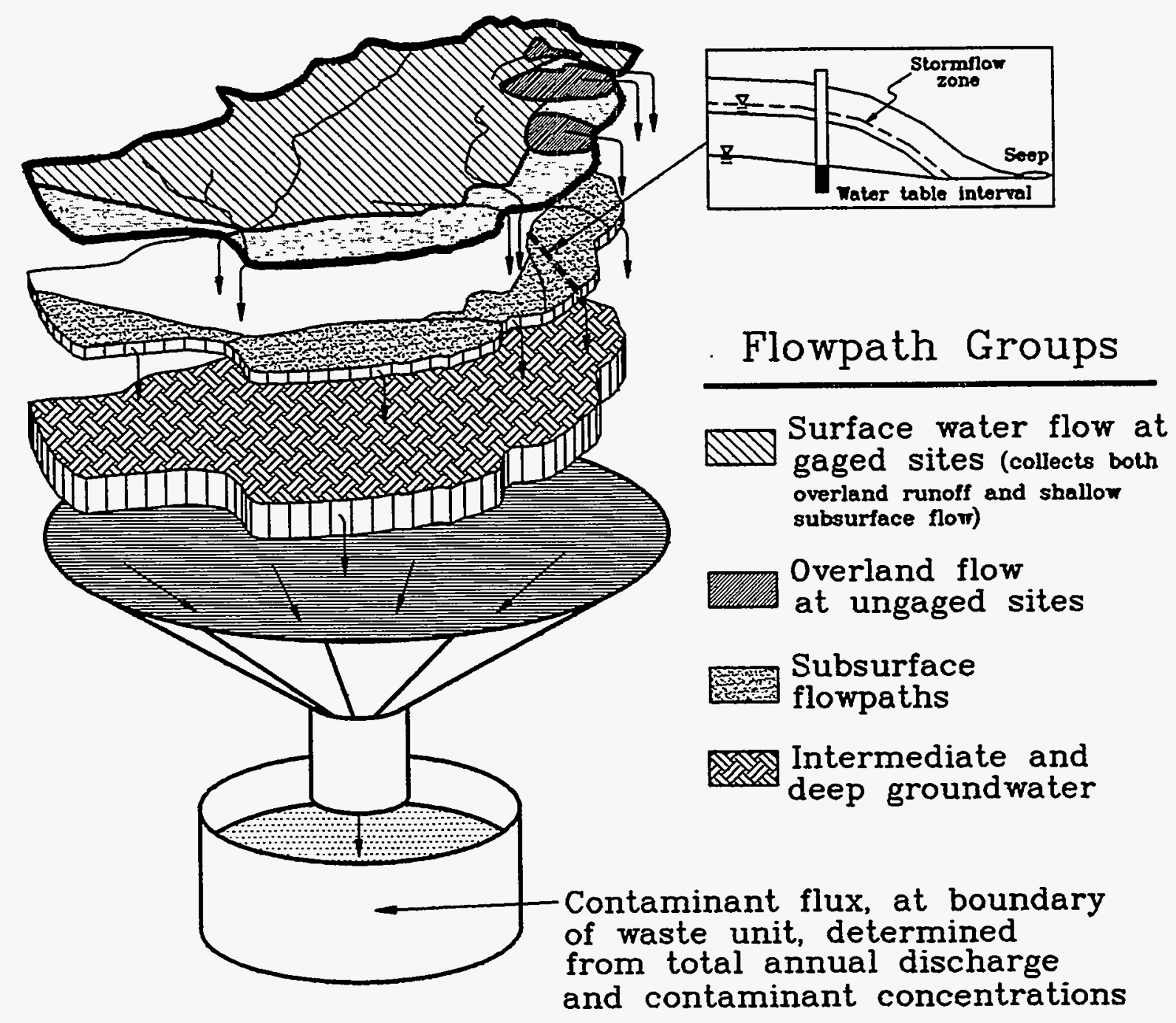

Fig. 1.10. Waste Area Grouping 6 flow path groups. 
The WAG 6 monitoring strategy uniquely focuses on total contaminant flux rather than contaminant concentration at selected sites (wells or weirs), typical of conventional CERCLA evaluations. Calculation of contaminant flux requires the use of models (conceptual and mathematical) to utilize both concentration measurements and estimates of water flow. The WAG 6 approach to monitoring may be adapted to other WAGs, but WAG 6 is unique in that it has a large ungaged perimeter whereas the other WAGs tend to drain directly to weirs with monitoring stations. Therefore, future monitoring at other WAGs will not be as complex as that at WAG 6.

\subsubsection{WAG 11}

WAG 11, also known as the White Wing Scrap Yard (Fig. 1.11), was used for aboveground storage of scrap metal and debris from the early 1950s through the mid-1960s. WAG 11 received a variety of sizes and types of equipment and material, e.g., steel tanks, vehicles, metal supports, glass, graphite, concrete, plastic, wood, and composite materials. WAG 11 contained construction debris mostly contaminated with radionuclides; however, during the removal action, some polychlorinated biphenyl- (PCB-) contaminated waste from ruptured capacitors was found at the site.

Between December 1986 and July 1991, measurement surveys of alpha, beta, and gamma radiation were taken throughout much of WAG 11 . Some radiological contaminants are present on the debris in levels high enough to be of concern. A fence has been erected to restrict the access of any inadvertent intruder(s). Most of the larger scrap was removed from the surface of WAG 11 during the late 1960s and early 1970s. Although materials and debris are buried on site, implementation of the Interim Record of Decision (IROD) for ORNLWAG 11 Surface Debris, (DOE 1993b), only covered the removal of contaminated surface debris. In the fall of 1993, approximately $10,000 \mathrm{ft}^{3}$ of metal and concrete debris was removed from WAG 11 and taken to WAG 6 for disposal. Removal of the surface debris satisfied the Interim Record of Decision requirements, but a final Record of Decision for WAG 11 must take account of the large volumes of buried debris. Any buried scrap debris and contaminated soil will be remediated at later periods in the overall WAG 11 remediation schedule. A team from ORNL's Chemical Technology Division will spearhead the pilot scale treatability studies for this waste. No data have been collected from the groundwater wells in WAG 11. WAG 11 now ranks as a low priority site, and the remedial investigation/feasibility study phase is not planned until 2004 or beyond.

\subsubsection{WAG 13}

The WAG $13{ }^{137} \mathrm{Cs}$ plots near ORNL consist of a 6-acre fenced area located approximately $330 \mathrm{ft}$ north of Clinch River at mile 20.5 and 1.3 miles south of the intersection of Bethel Valley Road and Tennessee State Route 95. WAG 13 contains eight treatment plots and an experimental runoff study area (Fig. 1.12). Each of the eight plots is 33 by $33 \mathrm{ft}$ and is enclosed in sheet metal extending $18 \mathrm{in}$. below the surface and $24 \mathrm{in}$. above grade. As part of a nuclear weapons fallout experiment in 1968 , ORNL scientists dispersed ${ }^{137} \mathrm{Cs}$ fused to sand particles into four of the eight plots.

WAG 13 contains two operable units: the ${ }^{137} \mathrm{Cs}$ test plots and an experimental study area. The water table at WAG 13 is approximately $8 \mathrm{ft}$ below the surface, so ${ }^{137} \mathrm{Cs}$ contamination could migrate through groundwater at the site. The Interim Record of Decision (IROD) for ORNL WAG 13 Cesium Plots (DOE 1992b), Sept. 1992, called for the excavation 

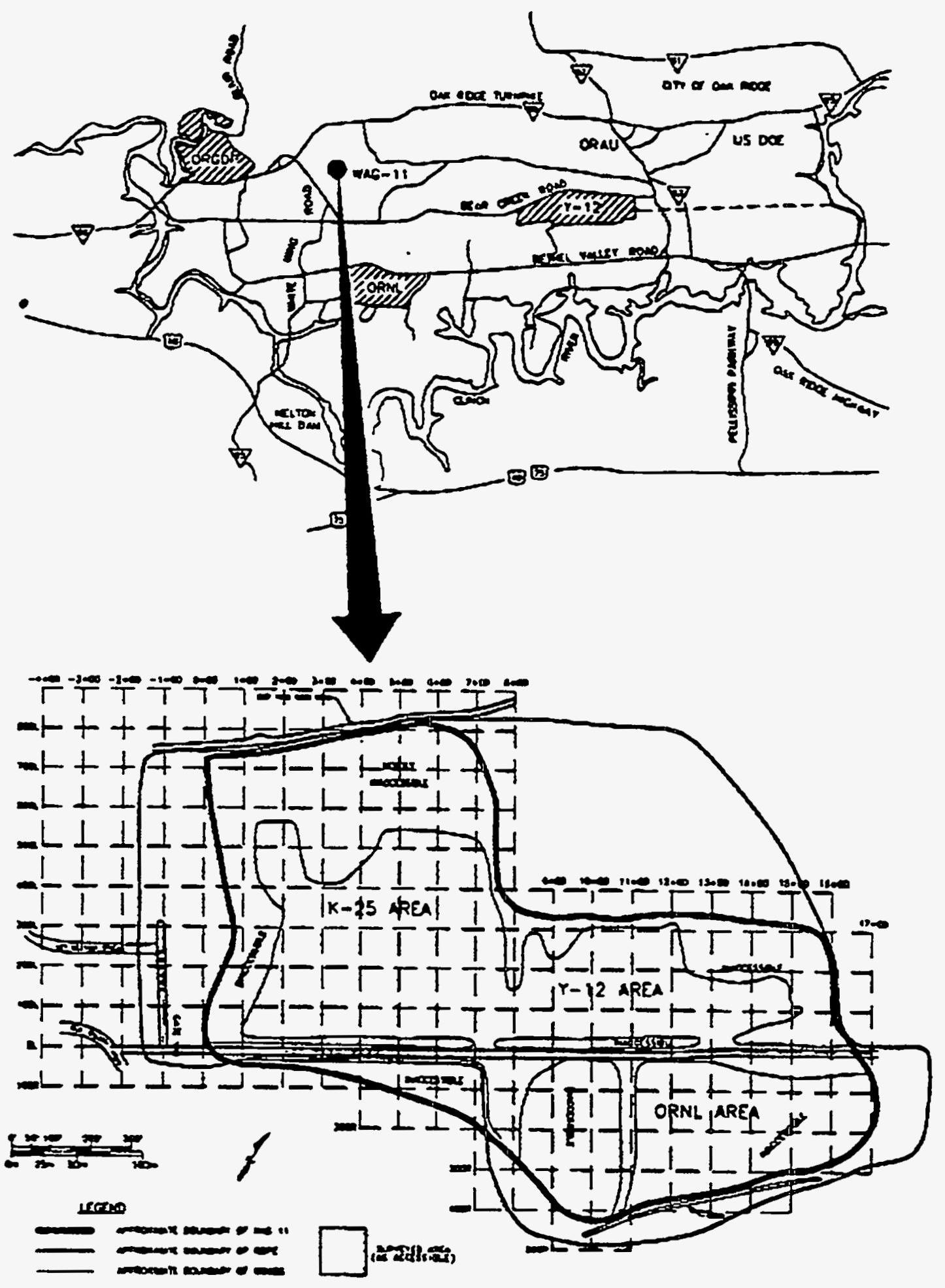

Fig. 1.11. Waste Area Grouping 11. 


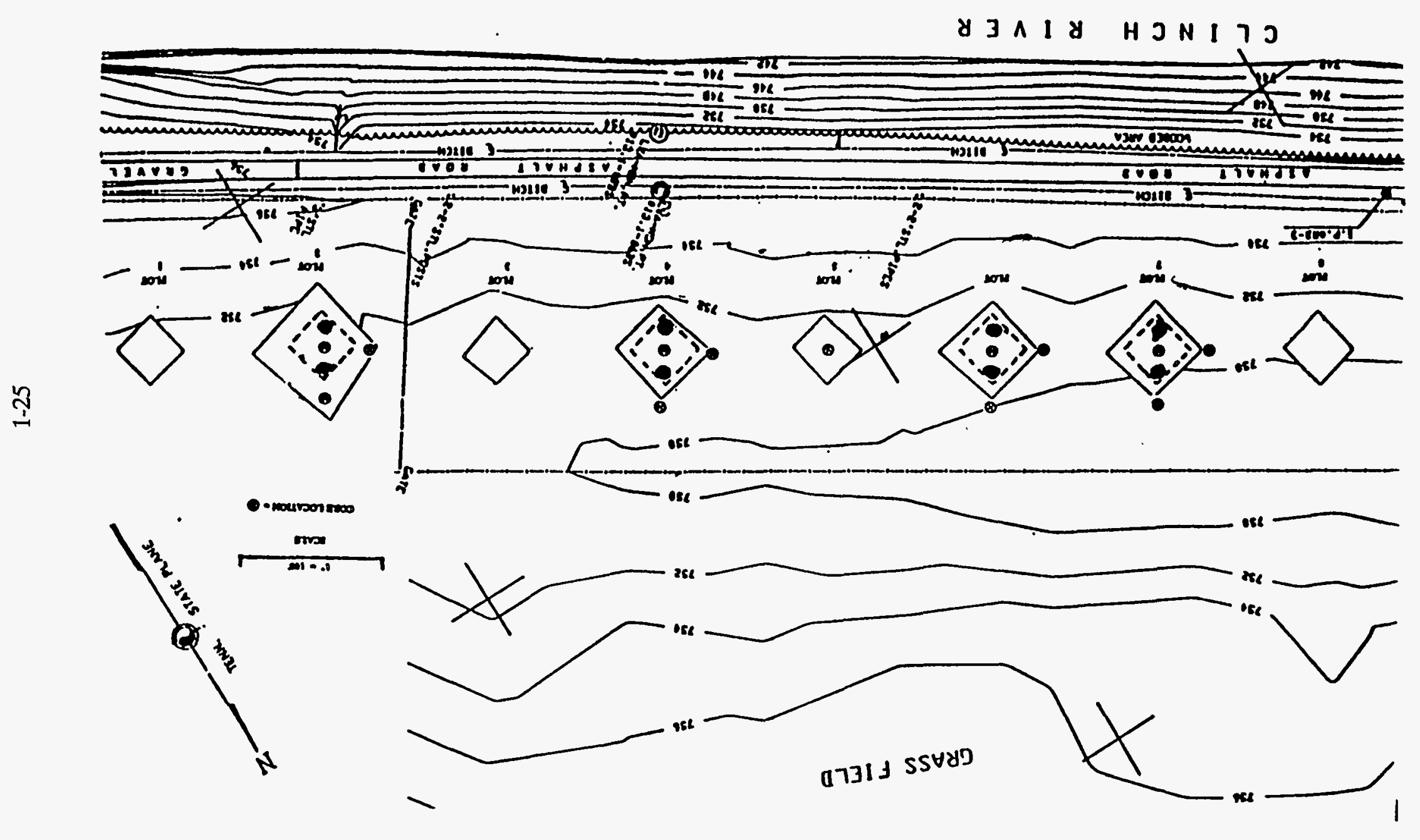


of soil from the four test plots injected with ${ }^{137} \mathrm{Cs}$.

Beginning in September 1993 and continuing through the first few months of FY 1994, the ORNL ER Program excavated the soil to a depth of approximately 3.5 to $4 \mathrm{ft}$. The contaminated soil was then transported to WAG 6 for disposal in underground silos. As of November 1993, the WAG 13 team had completed the task and excavated approximately 11,000 to $12,000 \mathrm{ft}^{3}$ of soil.

The ER Program intended to file a No Further Investigation petition for the second operable unit study area. However, detection of ${ }^{137} \mathrm{Cs}$ in levels greater than $(>) 120 \mathrm{pCi} / \mathrm{g}$ in this study area meant that U.S. Environmental Protection Agency and Tennessee Department of Environment and Conservation would not grant the No Further Investigation petition. The No Further Investigation petition will be removed from the WAG 13 scope of work, and nothing more is currently planned for the second operable unit area. Risk of potential gamma radiation exposure to fishermen on White Oak Creek triggered a fast track response to remediate WAG 13 under CERCLA. Surface runoff from WAG 13 follows a path to the floodplain in the northwest corner of the site. The runoff has created a surface zone or pathway of slightly contaminated soil that remains in place. Trace amounts of ${ }^{137} \mathrm{Cs}$ left at the site meet the U.S. Environmental Protection Agency/Tennessee Department of Environment and Conservation target level of less than $120 \mathrm{pCi} / \mathrm{g}$ and thus require no further treatment.

The ER Program will continue to monitor the WAG 13 site, as required by CERCLA, to ensure the removal action reduced the risks posed by WAG 13 contamination to acceptable levels.

\subsubsection{WAG 7}

WAG 7 includes pits and trenches used from 1951 to 1966 for low-level liquid waste disposal. Remedial activities involve the in-situ vitrification of Pit 1 in November 1994. Pit 1 contains ${ }^{137} \mathrm{Cs}$ and relatively minor amounts of ${ }^{90} \mathrm{Sr}$ according to the Treatability Study Work Plan for In-Situ Vitrification of Seepage Pit 1 in WAG 7 at ORNL (DOE 1993c), December 1993. The treatability study will support an Interim Record of Decision or removal action for closure of one or more of the seepage pits and trenches in FY 1996. In-situ vitrification involves placing electrodes in an array above a contaminated volume of soil, applying electrical power to the electrodes, and melting the entire mass of soil into a chemically homogeneous and durable glassy-to-microcrystalline waste form (Handbook of vitrification technologies for treatment of hazardous and radioactive waste, EPA/625/R-92/002, U.S. EPA, 1992). The melt dissolves and/or incorporates radionuclides and nonvolatile hazardous elements, such as heavy metals, and destroys organic components by pyrolysis. Semivolatile organics are largely retained in the melt, but the small quantity of material that does escape from the melt is captured and treated.

\subsubsection{WAG 10}

WAG 10 includes the subsurface components associated with hydrofracture injection operations in Melton Valley and consists of three operable units: (1) the deep groundwater, (2) the hydrofracture grout sheets, and (3) well and borehole plugging and abandonment. The ORNL ER Program only has activities planned for well and borehole plugging and abandonment. Samples from 23 of the existing wells at the Old Hydrofracture Facility will be 
taken for waste characterization and to provide data for protecting workers at the site from unsafe exposure during fracture well plugging and abandonment efforts.

\subsection{THE HYDROLOGIC SYSTEM AT ORNL}

Because surface water is the main driver for contaminant transport leading to off-site exposures and because groundwater provides the linkage between the buried waste and the surface water pathway, the reader must be at least somewhat familiar with the hydrologic system at ORNL to understand the monitoring summaries of this report. In ERMA (1992) the ORNL site conceptual hydrologic model was explained in detail; a brief synopsis is offered here.

The development of the conceptual hydrologic framework by the Oak Ridge Reservation Hydologic and Geologic Study team (Solomon, et al. 1992) for the Oak Ridge Reservation has been the basis of ORNL site-specific and WAG-specific conceptual hydrologic models. The conceptual framework emphasizes the importance of several mechanisms affecting contaminant transport:

- In the Melton Valley shale formations where most of the waste is buried at ORNL, the subsurface hydrology is divided into the near-surface stormflow zone, the vadose zone, and the groundwater zone, as shown in Fig. 1.13. The groundwater zone is divided into the relatively thin upper water table interval, intermediate and deep intervals, and a briny aquiclude that is not shown in Fig. 1.13.

- Lateral flow in the transient near-surface stormflow zone and, to a lesser degree in the shallow water table interval, account for most of the flow to tributaries and streams.

- The depth to the water table zone generally conforms to the depth of unweathered bedrock, with the water table mimicking the surface topography.

- Flow in the groundwater zone is affected by fracture zones that cause preferential flow in the strike direction (anisotropy).

- Fractures provide discrete flow paths, and they conduct material between buried wastes and seeps where contaminated groundwater emerges at the surface.

- In a subsurface regime that is both fractured and porous, matrix diffusion stores and buffers the contaminants transported from primary waste sources to seeps and springs.

- The buffering effect safeguards the system from sharp increases in surface water concentrations.

Because of the complex hydrogeology of the Oak Ridge Reservation, the most difficult parameters to ascertain are contaminant movement in groundwater and the interaction between groundwater and surface water. This complexity necessitates a multifaceted groundwater investigation program to meet ER needs.

This conceptual framework then leads to the following implications. First, seeps and springs are considered to be better than shallow groundwater wells for monitoring 


\section{Dip Section}

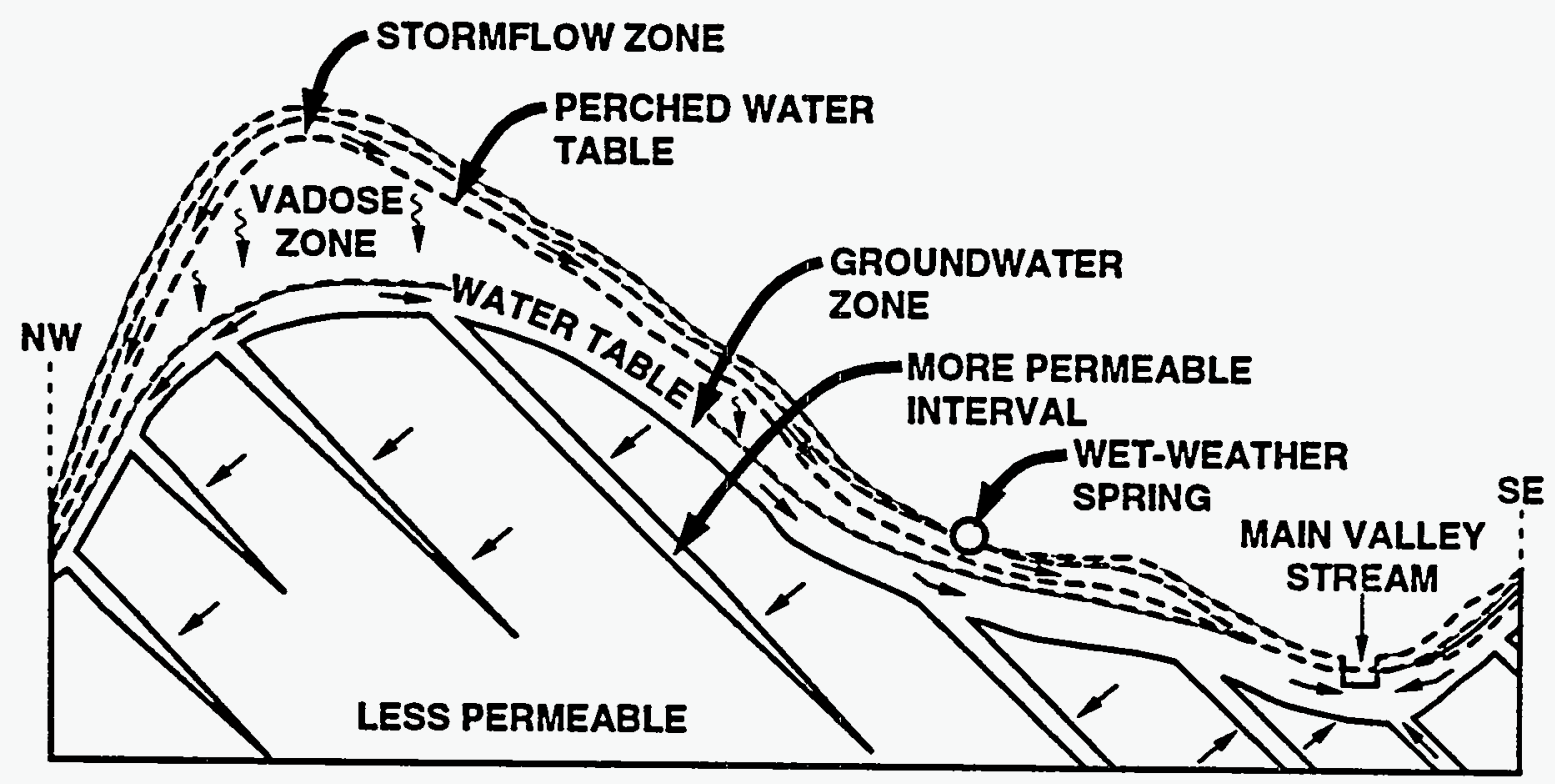

\section{Strike Section}

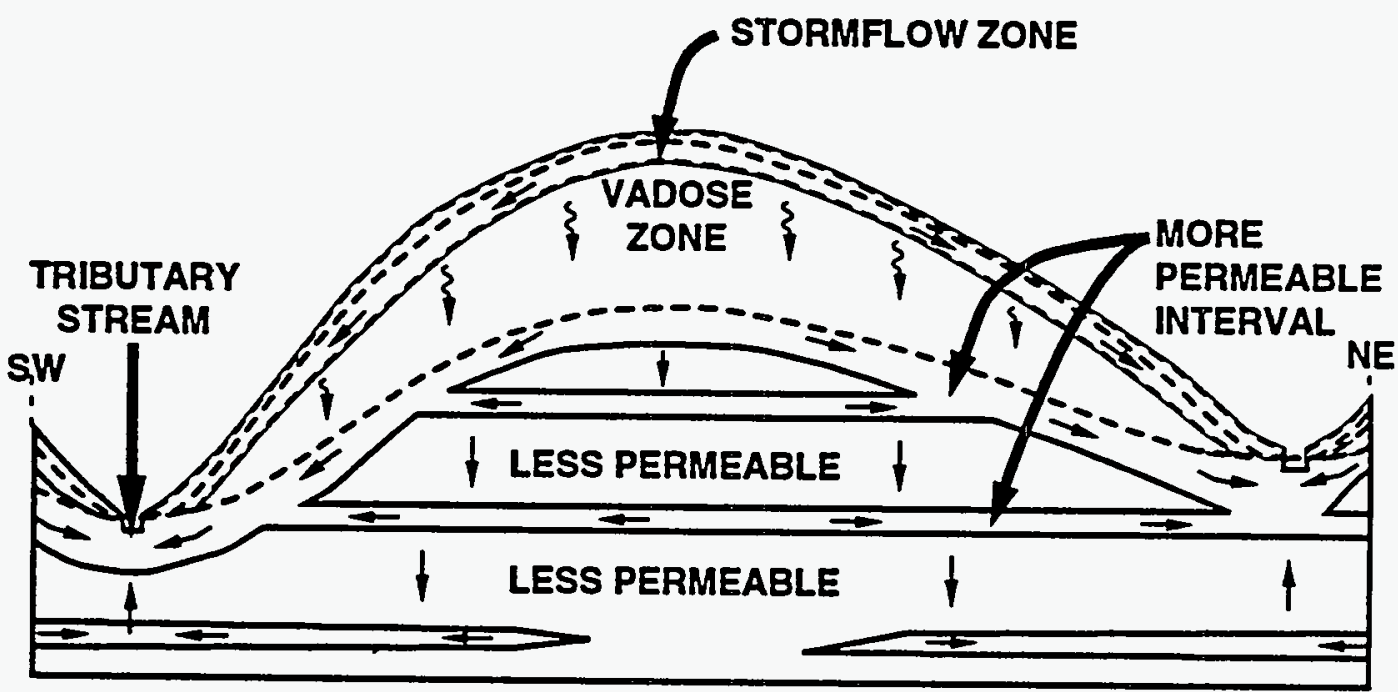

NOT TO SCALE

Fig. 1.13. Conceptual hydrologic model for subsurface flow in shale aquitard at the Oak Ridge Reservation. 
groundwater quality because they represent the active flow system. Second, stormflow is highly transient, and no method for directly monitoring water flow or quality has been devised. Indirect methods based on hydrograph separation or comparisons of discharge and concentration (Q-C) measured at weirs appear to be promising. A third implication is that a 3-dimensional model that can show the curved water table interval and dipping fractured zones can best portray groundwater flow paths at ORNL. Finally, when a buried waste container breaks open and releases large quantities of leachate, most of it diffuses into the soil or bedrock matrix. 


\title{
2. SURFACE WATER
}

\author{
D. M. Borders, R. B. Clapp, D. S. Hicks, and M. F. Tardiff
}

\section{INTRODUCTION}

Surface water is critically important because it transports contaminated groundwater that seeps to the land surface. It erodes and transports contaminated sediments, and it deposits those sediments downstream, potentially causing exposures to people and biota. At the ORNL site, surface water must be viewed as a component in an integrated hydrologic system. The hydrologic cycle for ORNL consists of inputs, transports, and outputs. Precipitation and plant effluents are the inputs; overland flow, storm flow, and shallow and deep groundwater flow are transports; and evapotranspiration and surface water discharge at the site perimeter are the outputs. How the cycle is characterized and the type of data that are collected to analyze the cycle depends upon the purpose of the investigation. The purpose of the ER Program for analyzing the hydrologic cycle is to understand how contaminants move from sources to potential receptors. While contaminants can be introduced at any point in the cycle, the majority of contaminant transport at ORNL occurs in the shallow groundwater, storm flow, and surface water components. The distinction between surface water and groundwater, as it appears in regulations and as reported herein, is largely artificial because most of the surface water in the geological setting at ORNL has infiltrated into the soil, traveled through the subsurface, and emerged at springs or seeps (Solomon et al. 1992).

Surface water monitoring and assessment activities largely fall into four separate tasks.

- The Watershed Hydrology Task provides rainfall and discharge measurements used for data analysis, calculating contaminant fluxes, and modeling contaminant transport through the White Oak Creek system. The modeling effort, in turn, assists in evaluating the effects of alternative designs for proposed remedial actions.

- The Seep Task collects radiological and chemical data from seeps, tributaries, and main stream sites. These data provide "snapshots" of contaminant sources and movement throughout the watershed, but especially in the vicinity of WAG 2. The data depict the spatial distribution of contaminant sources.

- The Tributary Assessment Task performs intensive sampling at tributaries known to contribute significant amounts of contamination to the White Oak Creek system. The data collected under this task show the effects of storms on contaminant transport; they also help identify the mechanisms of contaminant mobilization and transport.

- The Surface Water Chemistry Task gathers data collected by the Office of Environmental Compliance and Documentation, Environmental Surveillance and Protection Section to determine flux throughout the system. Under this task, technical staff interpret hydrologic and contaminant data to improve our conceptual model of contaminant mobilization and transport on a watershed scale. 
Section 2.2 presents the conceptual model of contaminant transport as waste moves from the disposal facility to the surface water. Analysis of data collected at the main weirs (Sect 2.5) reveals an annual cycle in the contaminant transport that is now included in the conceptual model.

Section 2.3 summarizes the hydrological data collected in the White Oak Creek watershed and used in the analysis of environmental data, design of remedial actions, and computer modeling.

Section 2.4 presents spatial patterns and fluxes of radionuclides in seeps, tributaries, and main streams. The section also lists the annual contaminant fluxes from White Oak Creek to the Clinch River. Risk due to ingestion of surface water is based on the data reported in this section.

Section 2.5 describes the seasonal changes of contaminant transport based on several years of monthly data collected at the main weirs. These results show the influence of the groundwater system in mobilizing contaminants during the wet season.

Section 2.6 provides a summary of the section.

\section{HYDROLOGIC CONCEPTUAL MODEL: CONTAMINANT DISCHARGE FROM TRIBUTARIES}

The ORNL hydrologic site conceptual model has focused largely on the flow paths and transport mechanisms of contaminants moving from buried waste sources to receiving streams. The dynamics of contaminant concentration and flux vary within storms and also throughout the year. Data presented in this section describe contaminant movement on hourly, monthly, and annual time scales. Enhanced understanding of the physical transport mechanisms that cause these temporal variations can lead to improved monitoring and assessment of remedial actions, better designs of remedial actions, and thus cost savings for the ORNL ER Program.

In this subsection, the site conceptual model is briefly reviewed. That model pertains to flow mechanisms that transport contaminants from waste sites to nearby tributaries during a storm. Data supporting the conceptual model are presented in Sect. 2.4.2. Those data show a clear trend of dilution during storms, however, the data also suggest a seasonal trend. This seasonal trend is actually an annual cycle between a wet season and a dry season, and the cycle is explored in the analysis described in Sect. 2.5.

In the conceptual hydrologic model for subsurface flow (shown in Fig. 1.13), nearly all precipitation falling on hillslopes underlain by shale formations (where most of the buried waste is located) infiltrates into the soil. Most of the infiltrated water moves laterally to nearby tributaries via the macropores and fractures in the stormflow zone (upper 1-2 $\mathrm{m}$ of soil). A small portion of the infiltrated water moves vertically to the water table, where it again tends to move laterally to the nearby tributary via fractures in the saprolite (weathered rock) and bedrock. This shallow groundwater zone is termed the water table interval. A very small portion moves downward to the intermediate and deep groundwater intervals. Contaminants leached from shallow burial trenches can be transported in all of these flow paths. 
Figure 2.1 depicts the conceptual model of tributaries that drain into the main streams at ORNL. As shown, subsurface flow paths conduct water and leached contaminants from disposal sites to the receiving tributaries. Three regimes or stages of streamflow in tributaries can be defined.

1. Under baseflow conditions, stream flow is generated entirely from groundwater contributions from lateral flows draining the shallow water table interval plus minor groundwater input from the intermediate zone.

2. During moderate precipitation events, rainwater infiltrates into the surface soil layer and reaches the stream via shallow subsurface stormflow (lateral flow in the upper $2 \mathrm{~m}$ of the soil).

3. During extreme storm events, the intensity of precipitation is greater than the infiltration capacity of the surface soil, and rainwater collects on the surface and flows downslope to the stream as overland flow.

The three flow regimes described above define the conditions that transport contaminants into tributaries and to their eventual discharge off-site. Figures $2.2 \mathrm{a}$ and $2.2 \mathrm{~b}$ illustrate the relationships between discharge, contaminant flux, and contaminant concentration versus time, and the same information is expressed by the log transformations, respectively. The log-log plot of concentration (C) versus discharge (Q) (Fig. 2.2b) is termed the "C-Q plot," and it is divided into segments. In the conceptual model these segments are related to streamflowgenerating mechanisms. The constant concentration segment corresponds to baseflow (i.e., groundwater discharge), the first sloped section corresponds to shallow stormflow (reduced concentration but increased contaminant flux), and the segment with the steepest slope corresponds to overland flow (complete dilution of rainwater mixing with contaminated groundwater discharge).

Comparison of $\mathrm{C}-\mathrm{Q}$ relationships before and after remediation provides a direct method for determining the effectiveness of a remedial action. This concept has been described and illustrated in previous ERMA reports $(1992,1993)$

Analysis for C-Q relationships using data collected during storms shows a seasonal aspect to the C-Q relationships. This seasonal trend was first identified in ERMA (1993), and it is analyzed in Sect. 2.5. Identification of these trends in the surface water chemistry data is important to the ER Program because they enhance our understanding of the processes that contribute to risk/dose from contaminant sources.

\subsection{SURFACE WATER HYDROLOGY}

The annual hydrologic data summary report for White Oak Creek (Borders et al. 1994) provides hydrologic data for ER activities that use monitoring data to quantify and assess the impact from releases of contaminants from ORNL WAGs. Surface-water data available within the White Oak Creek flow system include discharge and runoff, surface-water quality, radiological and chemical contamination of sediments, and descriptions of the monitoring stations in the White Oak Creek flow system. 


\section{Discharge and Soluble Contaminant Fluxes Draining ORNL Disposal Sites}

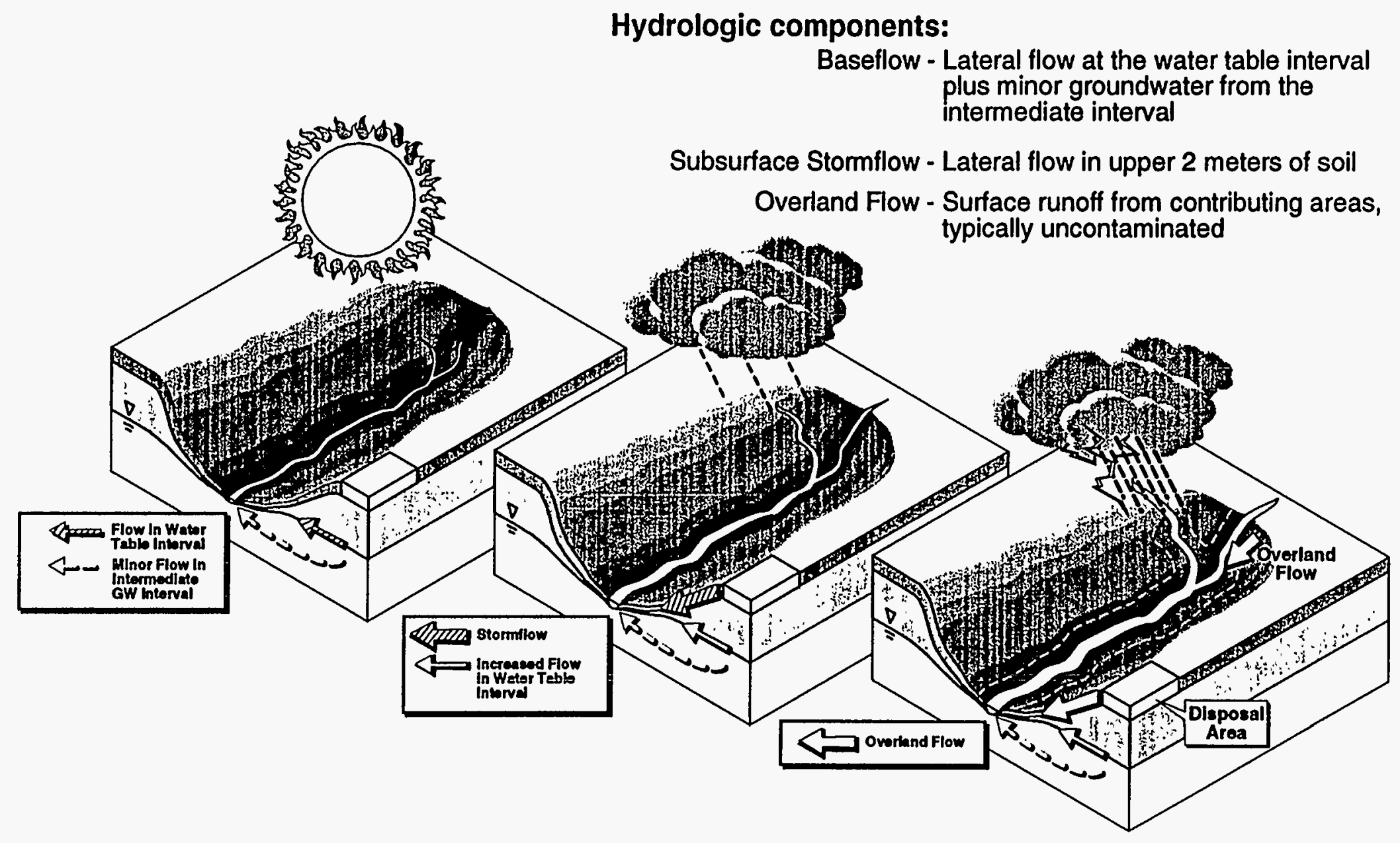

Fig. 2.1. Conceptual model for tributaries draining ORNL waste sites. 
ORNL DWG 93M-9354

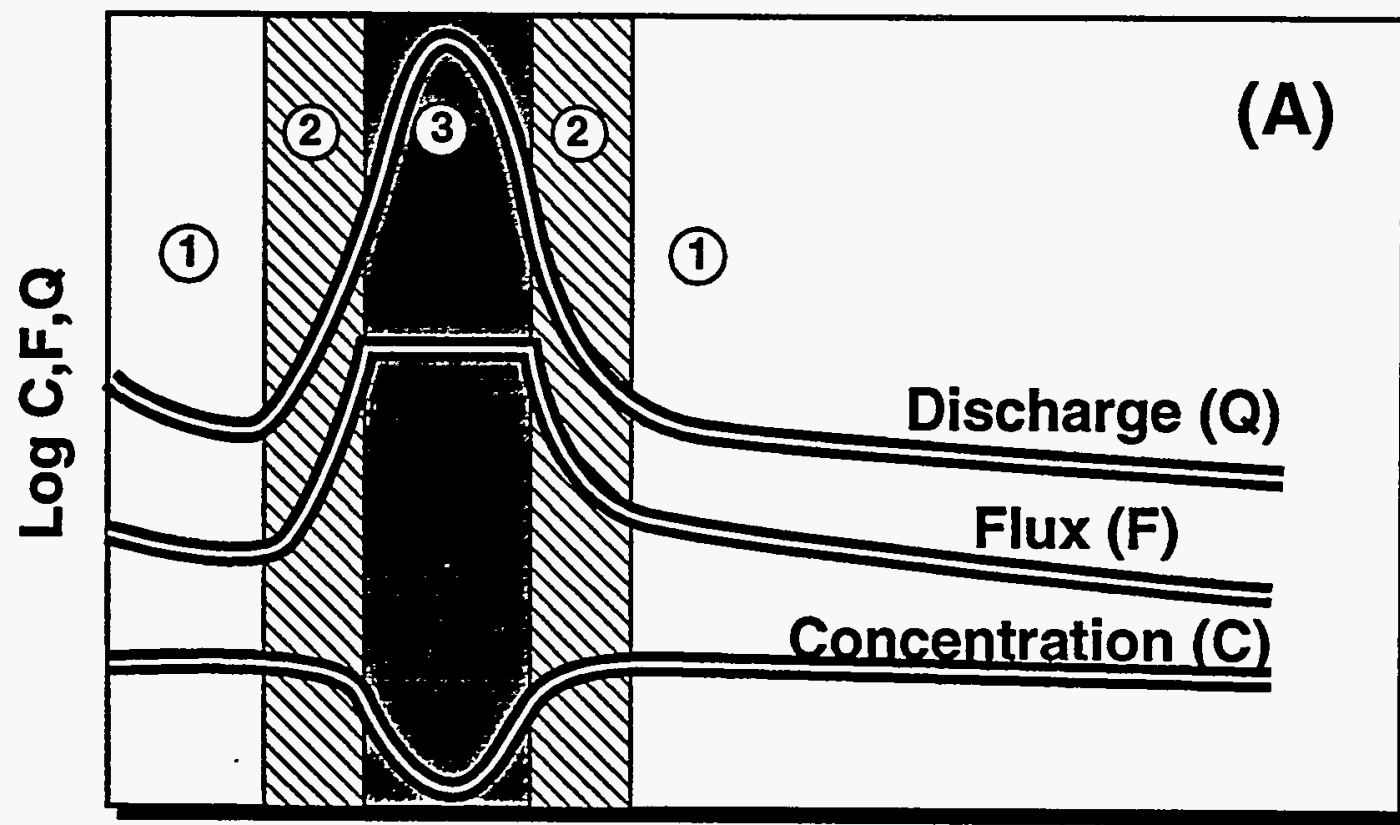

Time

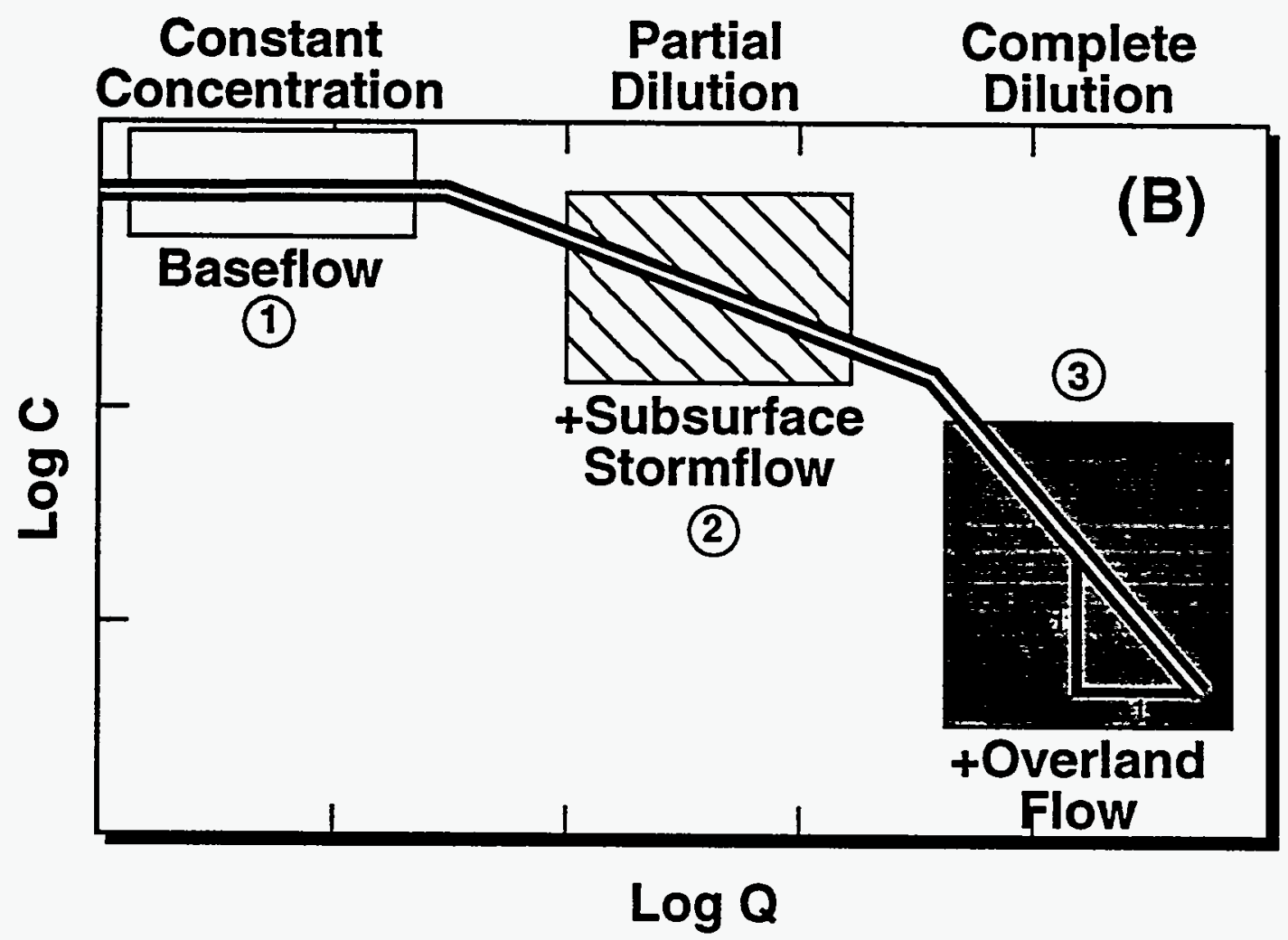

Fig. 22. Conceptual model relating discharge, contaminant flux and contaminant concentration vs time in (A) and log transformation in (B). 


\subsection{Precipitation}

WAG 2/SI staff collect precipitation data at nine sites in the White Oak Creek watershed and vicinity. For calendar year 1993, total precipitation averaged $120.7 \mathrm{~cm}$ (47.51 in.) for raingages located in the vicinity of the White Oak Creek watershed. Precipitation measured at the Oak Ridge site maintained by the National Oceanographic and Atmospheric Administration was comparable, $124.5 \mathrm{~cm}$ (49.02 in), or $91 \%$ of normal precipitation. This is the second year of below-normal precipitation following a 3-year period of above-normal precipitation, which followed the previous 4-year drought.

\subsection{Discharge}

Streamflow data are currently collected at 18 monitoring stations in the vicinity of the White Oak Creek watershed (Fig. 2.3). In the White Oak Creek watershed, there are at least eight more streamflow monitoring stations outfitted with at least a hydraulic control device (i.e., weir or flume) in various states of repair. Several of these sites (HRT adjacent to WAG 5, T2A and MS1 on the tributary below WAG 4, and the small flumes in WAG 6) were reactivated and instrumented in 1993 for discharge measurement and water quality sampling, primarily during storms.

The White Oak Creek surface-water flow system has been divided into a network of reaches (Fig. 2.4) to identify stream sections as measurable and manageable components of the hydrologic system. Table 2.1 lists the reaches and subreaches along with mean flows and mass balance data. Most reaches have a positive mass balance, in part because ungaged tributaries contribute runoff to the reach, although groundwater inputs can be important also. In addition, cumulative "dry" month losses that typically occur during the summer and early fall are presented for several major reaches. In terms of annual gains, these "dry" months are masked by high runoff in wet months. Mass balances for radionuclides and chemicals are possible for only a few reaches where there is continuous streamflow and water quality monitoring.

\subsection{CONTAMINANT TRANSPORT}

This section summarizes results from sampling and monitoring at seeps, tributaries, and stations on the main streams. The Seep Task frequently leads to extensive sampling across the watershed over 1 or 2 days. This sampling activity yields a spatial picture of where and under what flow conditions contaminants migrate into the surface-water system. The dynamic behavior of contaminant discharge can give insights as to whether the contamination travels via shallow or deep pathways. This behavior of contaminant discharge has significant consequences for planning remedial actions.

\subsubsection{Seeps}

Seeps represent the connections between the subsurface and surface-flow regimes and can mark the preferred groundwater and contaminant flow pathways. In addition to visible seeps, groundwater seepage directly into stream channels also occurs. The primary objective of the WAG 2 Remedial Investigation Seep Task is to identify seeps and areas of groundwater discharge that are significant sources of contaminants and to quantify their input to the total contaminant release from WAG 2. The Seep Task examines water quality and 


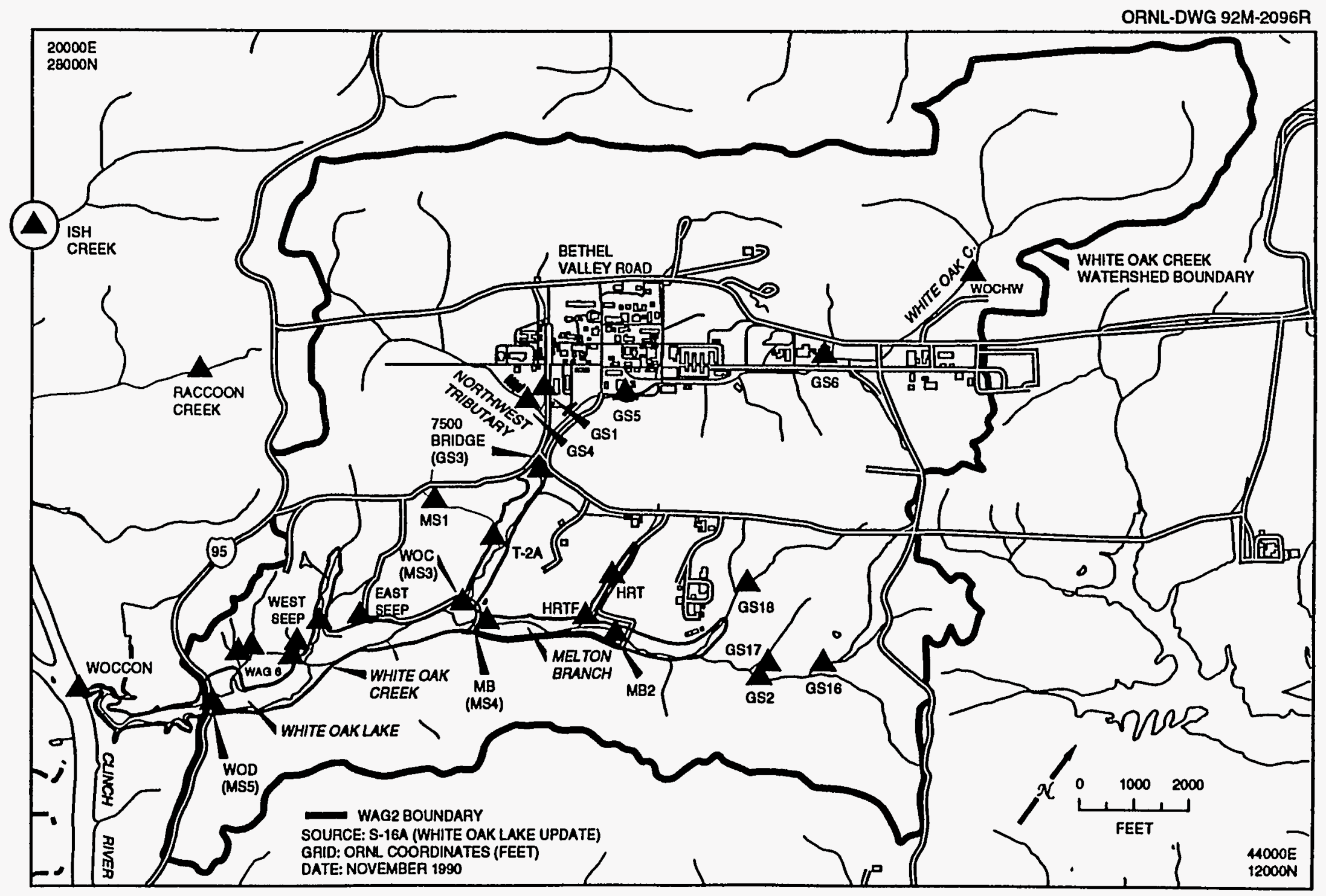

Fig. 23. Locations of surface water monitoring stations in the vicinity of the White Oak Creek watershed. 


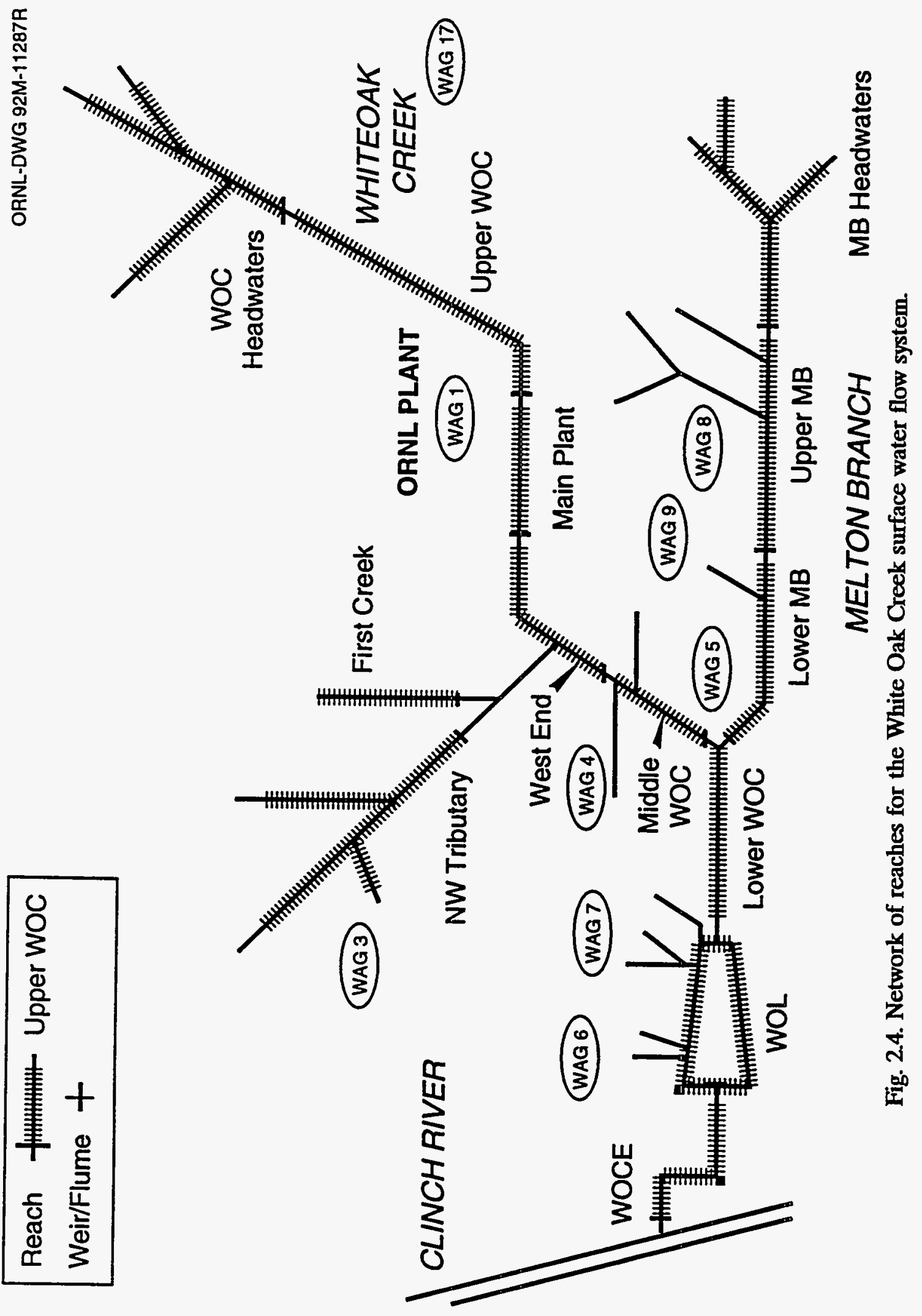


Table 2.1. Stream reaches in the White Oak Creek Watershed

\begin{tabular}{|c|c|c|c|c|c|c|c|c|}
\hline \multirow{2}{*}{$\begin{array}{l}\text { Subwatershed } \\
\text { reach/subreach }\end{array}$} & \multirow{2}{*}{$\begin{array}{l}\text { Area } \\
\left(\mathrm{mi}^{2}\right)\end{array}$} & \multirow{2}{*}{$\begin{array}{c}\text { Inc. area } \\
\left(\mathrm{mi}^{2}\right)\end{array}$} & \multicolumn{2}{|c|}{ Contributing tributaries } & \multirow{2}{*}{$\begin{array}{c}\text { CY } 1993 \\
\text { mean flow } \\
\left(\mathrm{ft}^{3} / \mathrm{s}\right)\end{array}$} & \multirow{2}{*}{$\begin{array}{c}\text { Gain }(t) \\
\text { or loss }(-) \\
\left(\mathrm{ft}^{3} / \mathrm{s}\right) \\
\end{array}$} & \multirow{2}{*}{$\begin{array}{l}\text { Cumulative dry } \\
\text { month losses } \\
\left(\mathrm{ft}^{3} / \mathrm{s}\right)\end{array}$} & \multirow{2}{*}{$\begin{array}{c}\text { Dry months } \\
\text { (1993) }\end{array}$} \\
\hline & & & Gaged & Ungaged & & & & \\
\hline \multicolumn{9}{|l|}{ Melton Branch } \\
\hline MB Headwaters & 0.499 & 0.499 & 1 & 0 & 0.55 & 0.55 & & \\
\hline Upper MB & 1.16 & 1.16 & 2 & 1 & $\mathrm{NA}^{a}$ & NA & $b$ & \\
\hline Lower MB & 1.51 & 1.51 & 2 & 0 & 2.43 & 1.88 & $b$ & \\
\hline \multicolumn{9}{|l|}{ Bethel Valley WOC } \\
\hline WOC Headwaters & 0.804 & 0.804 & 0 & 2 & 1.03 & 1.03 & & \\
\hline Upper WOC & 1.29 & 1.29 & 0 & 2 & 1.08 & 0.05 & -0.15 & $1-2,4-7$ \\
\hline Main Plant & 2.09 & 2.09 & 0 & 4 & 4.90 & 3.82 & & \\
\hline First Creek & 0.319 & 0.319 & 0 & 0 & 0.86 & 0.86 & & \\
\hline NW Tributary & 0.667 & 0.667 & 0 & 2 & 0.80 & 0.80 & & \\
\hline West End & 3.26 & 3.26 & 2 & 0 & 9.13 & 2.57 & & \\
\hline Middle WOC & 3.61 & 3.61 & 2 & 1 & 9.62 & 0.49 & -0.21 & 6 \\
\hline \multicolumn{9}{|l|}{ Melton Valley WOC } \\
\hline Lower WOC & 5.48 & 5.48 & 0 & 3 & NA & NA & & \\
\hline WO Lake & 6.15 & 6.15 & 6 & 4 & 12.43 & 0.38 & -0.25 & $1,2,6-8$ \\
\hline WOC Embayment & 6.5 & 6.5 & 0 & 1 & NA & NA & & \\
\hline Subtotal & & & 15 & 17 & & & & \\
\hline Total & 6.5 & & & 32 & & & & \\
\hline
\end{tabular}

${ }^{a} \mathrm{NA}=$ Not applicable or not available.

${ }^{b}$ Losses may occur in MB during dry months. 
contaminant fluxes (the product of concentration and flow) at all scales from the main streams to seeps throughout the White Oak Creek watershed. Tributaries are used as spatial integrators of contaminant releases from areas adjacent to WAG 2. Sampling along stream reaches (transects) allows for the identification of areas with significant contaminated groundwater discharge that may not have visible seeps.

During FY 1992 two extensive screening sampling rounds were conducted during baseflow conditions, once during the wet season and once during the dry season. Distributions of ${ }^{3} \mathrm{H},{ }^{90} \mathrm{Sr},{ }^{137} \mathrm{Cs}$, and ${ }^{60} \mathrm{Co}$ throughout the watershed have been reported in the ERMA report (1993) and the WAG 2 Phase I Remedial Investigation Report (DOE 1993d). Results from these two sampling rounds identified key seeps and areas that contribute significantly to the total contaminant flux in the White Oak Creek watershed. In addition, the results were used to direct early Removal Actions on specific ${ }^{90} \mathrm{Sr}$ source areas in WAG 5 (Newsom et al. 1993).

During FY 1993 two more extensive sampling rounds were conducted during wet- and dry-season baseflow conditions. Samples were collected from seeps, tributaries, and the main stream channels within the White Oak Creek watershed (Fig. 2.5). A round of samples was also collected following a large rain event, when subsurface stormflow was active, to examine the variability of source areas during different hydrologic conditions. Less extensive sampling done bimonthly was initiated in May 1993. The bimonthly sampling locations along the stream transect (Fig. 2.6) were chosen around approximately 10 key contaminant source areas to help estimate yearly contaminant fluxes as well as gain understanding about the effects of different hydrologic conditions on contaminant transport. Bimonthly samples are analyzed depending on their area and the main contaminants of concern. A greater focus was given to source areas of ${ }^{3} \mathrm{H}$ and ${ }^{90} \mathrm{Sr}$ because these two contaminants pose the greatest risk at White Oak Dam from water ingestion. Analyses of the data from the FY 1993 efforts are still in progress. A preliminary summary of the available data is given in this report. More thorough data analyses and a detailed report will be completed in 1995.

Transect sampling along Melton Branch in 1992 identified four areas of significant contaminant input from groundwater. These areas are associated with WAG 5 and were named Seep Areas A, B, C, and D as part of the WAG 5 remedial investigation efforts (Newsom et al. 1993). The 1993 data show that the inputs from these areas are still apparent based on increases seen in the ${ }^{3} \mathrm{H}$ and ${ }^{90} \mathrm{Sr}$ concentrations (Figs. 2.7 and 2.8). Seep Area A has a fairly discrete seep that discharges highly tritiated groundwater to the Melton Branch tributary. Discrete seeps have not been seen in Seep Area B where a more diffuse release of ${ }^{3} \mathrm{H}$ occurs along the southern boundary of WAG 5 (Fig. 2.7). Sharp increases of ${ }^{90} \mathrm{Sr}$ in Melton Branch occur as a result of input from Seep Area $C$ on the southern edge of WAG 5 (Fig. 2.8). This discrete seep is a major source of ${ }^{90} \mathrm{Sr}$ to the watershed. A less significant source, Seep Area D also has a discrete seep that releases ${ }^{90} \mathrm{Sr}$ to MBWEIR (Fig. 2.8).

Transect sampling was also conducted along the WAG 4 Tributary to determine if there were discrete sources for the high concentrations of ${ }^{3} \mathrm{H}$ and ${ }^{90} \mathrm{Sr}$ seen in the tributary. Most of the ${ }^{3} \mathrm{H}$ enters the tributary in the upper reach above W4TRIB-6 (Fig. 2.9). Decreasing ${ }^{3} \mathrm{H}$ concentrations after W4TRIB-6 indicate that groundwater with lower ${ }^{3} \mathrm{H}$ levels discharges into the tributary below this area. Changes in ${ }^{90} \mathrm{Sr}$ concentrations along the tributary suggest that

the two main source areas for ${ }^{90} \mathrm{Sr}$ are between W4TRIB-2 and W4TRIB-3 and around W4TRIB-12 (Fig. 2.10). 


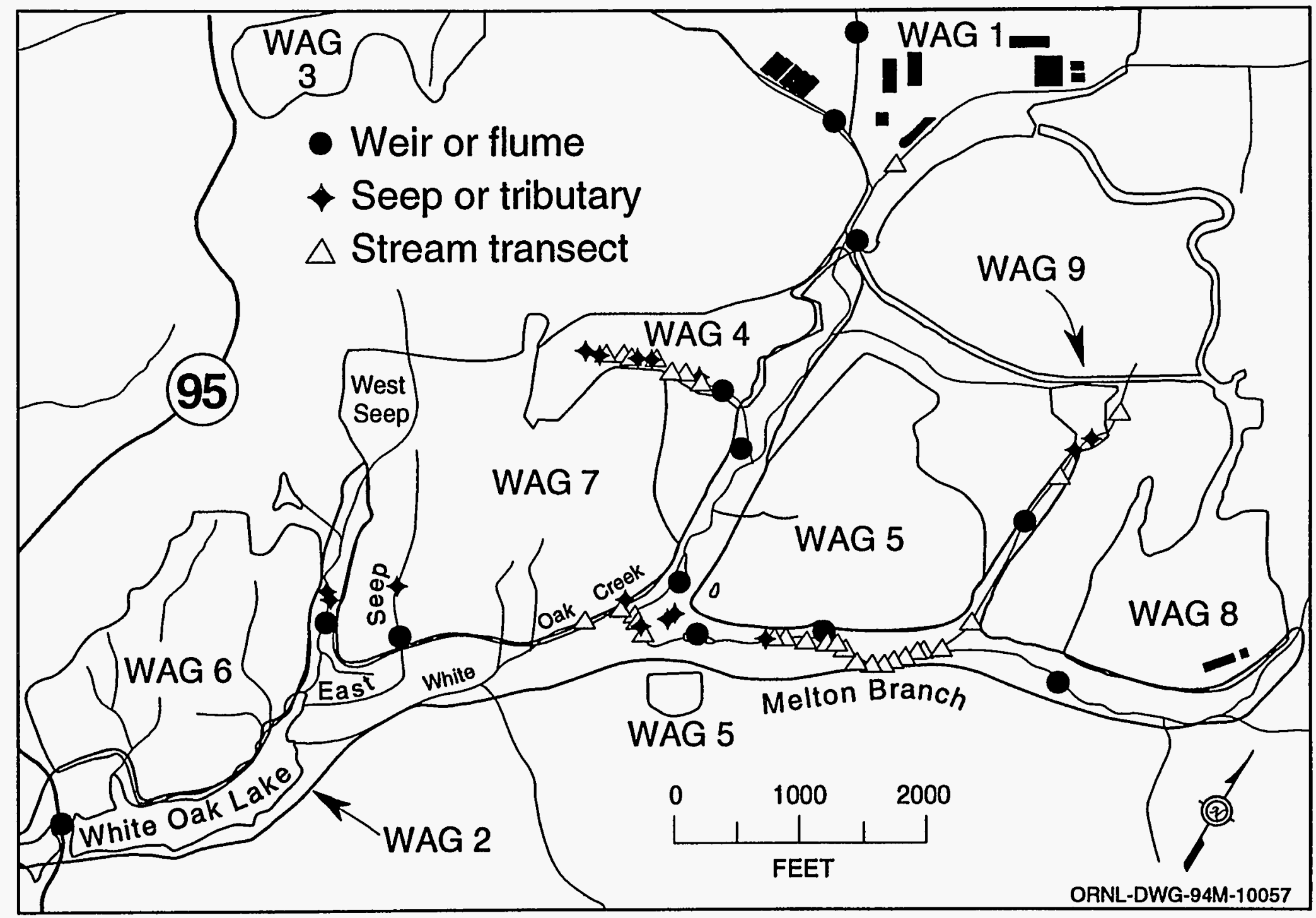

Fig. 2.5. Waste Area Grouping 2 Seep Task sampling locations in 1993. 


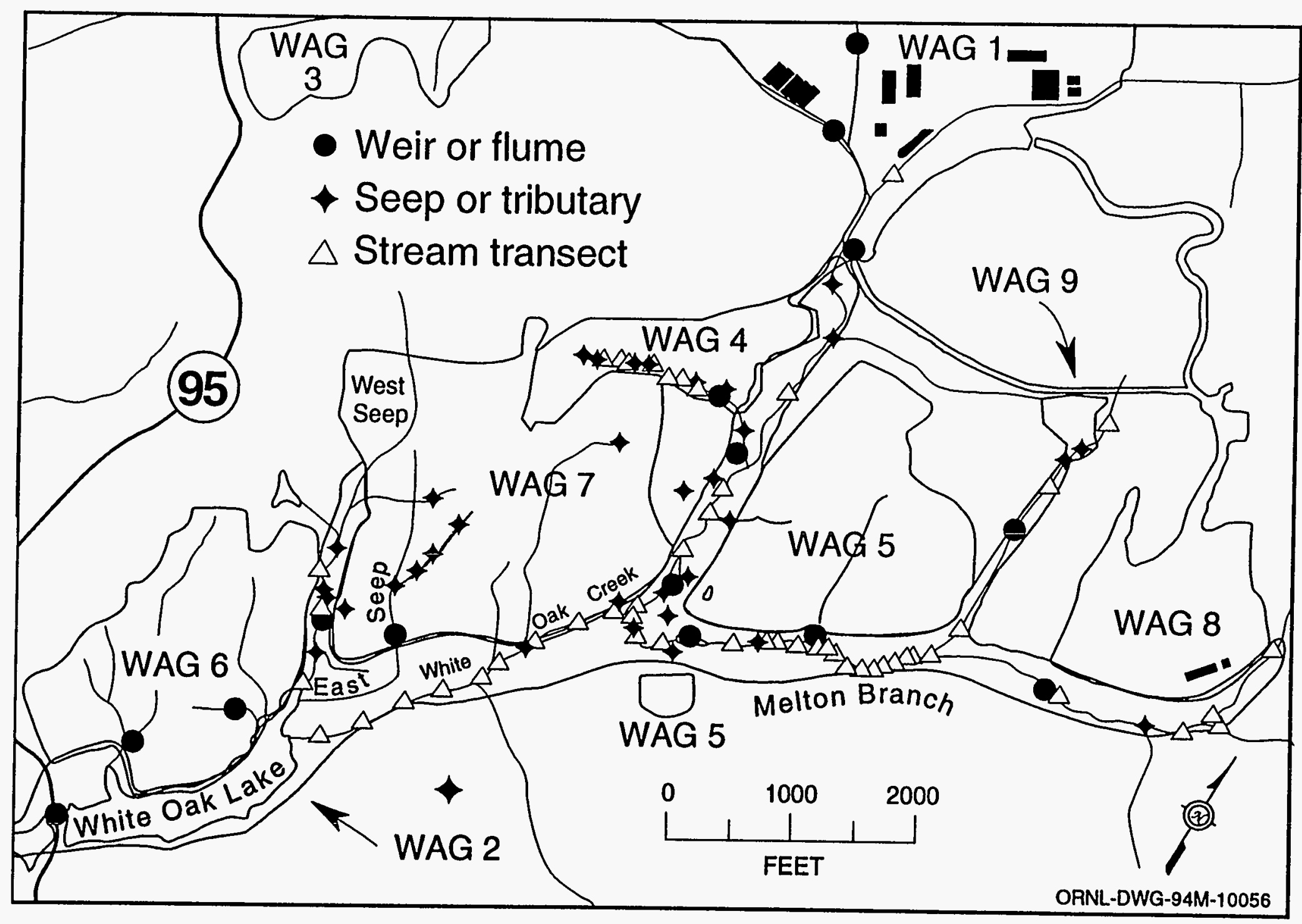

Fig. 2.6. Waste Area Grouping 2 Seep Task bimonthly sampling locations. 


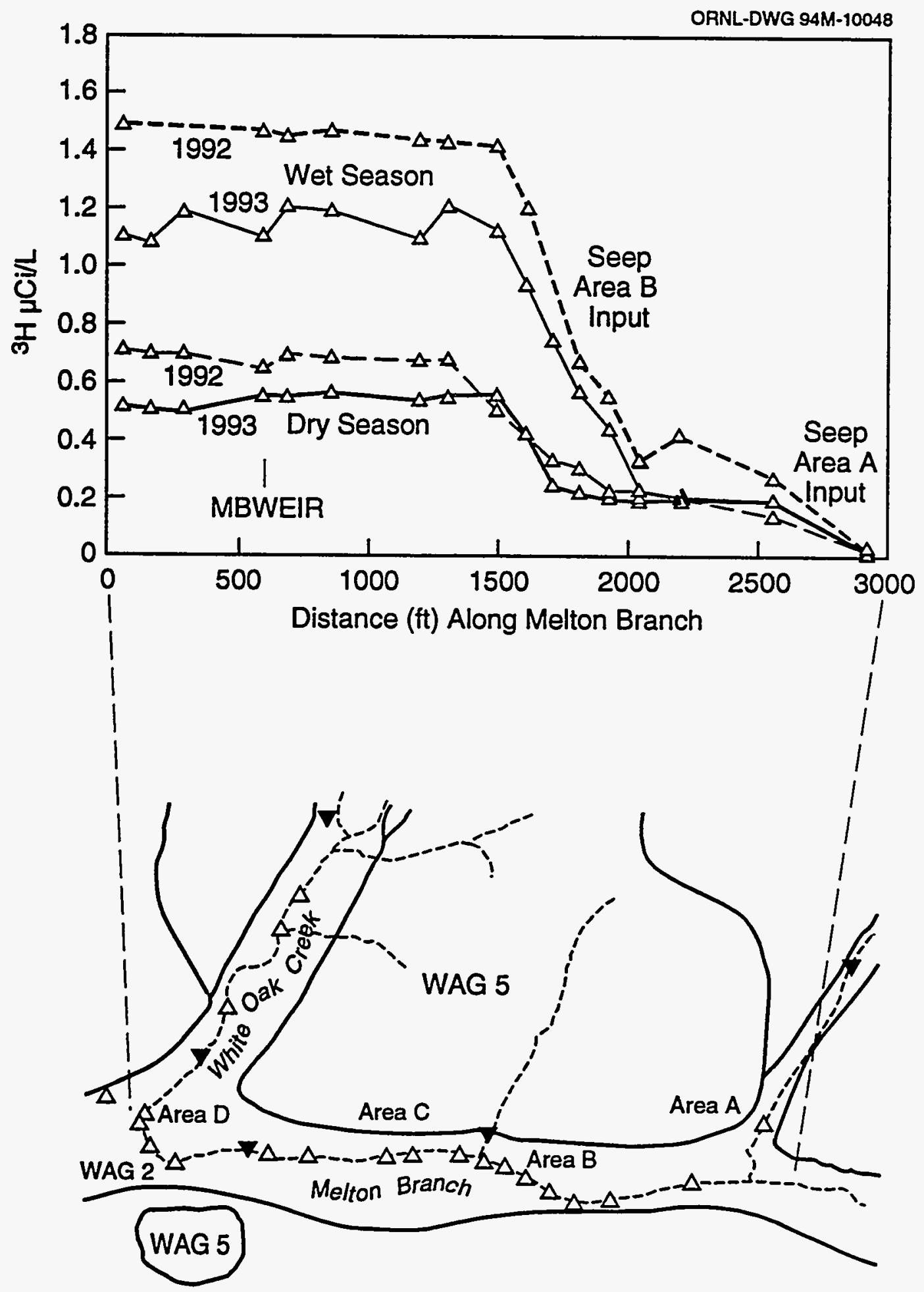

Fig. 2.7. ${ }^{3} \mathrm{H}$ results from sampling along a transect of Melton Branch. 


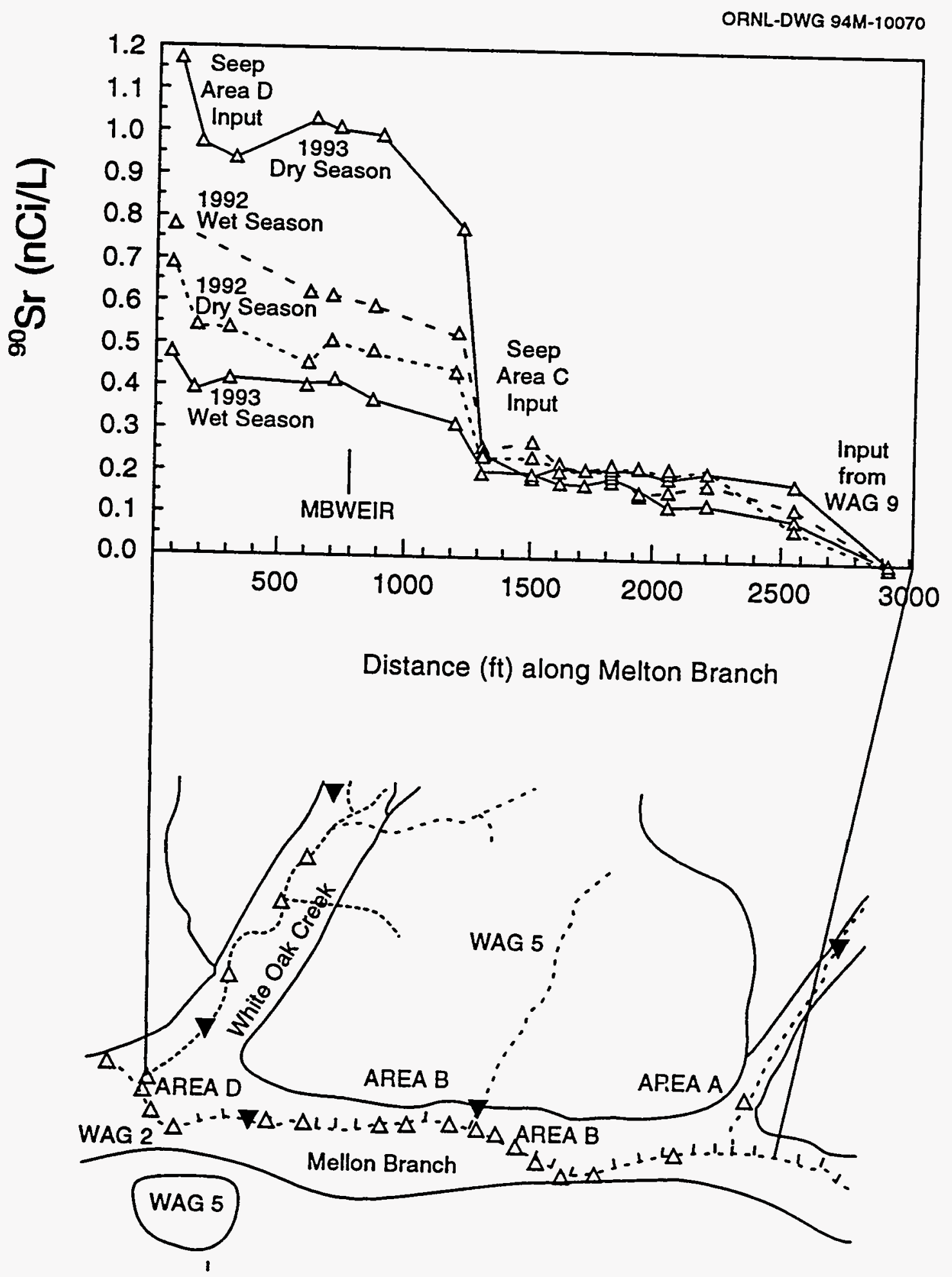

Fig. 2.8. ${ }^{90} \mathrm{Sr}$ results from sampling along a transect of Melton Branch. 


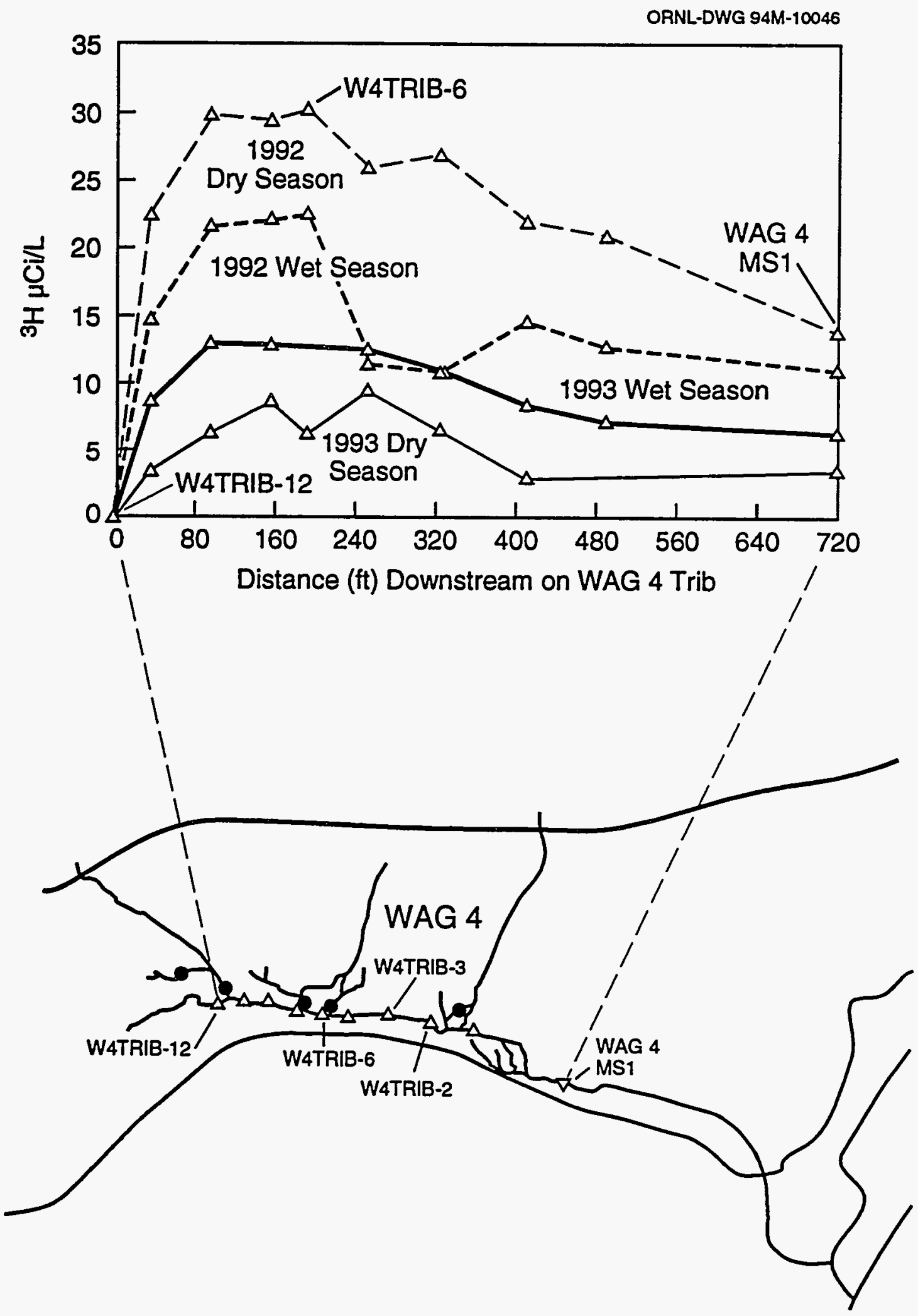

Fig. 2.9. ${ }^{3} \mathrm{H}$ results from sampling along a transect of the Waste Area Grouping 4 tributary. 


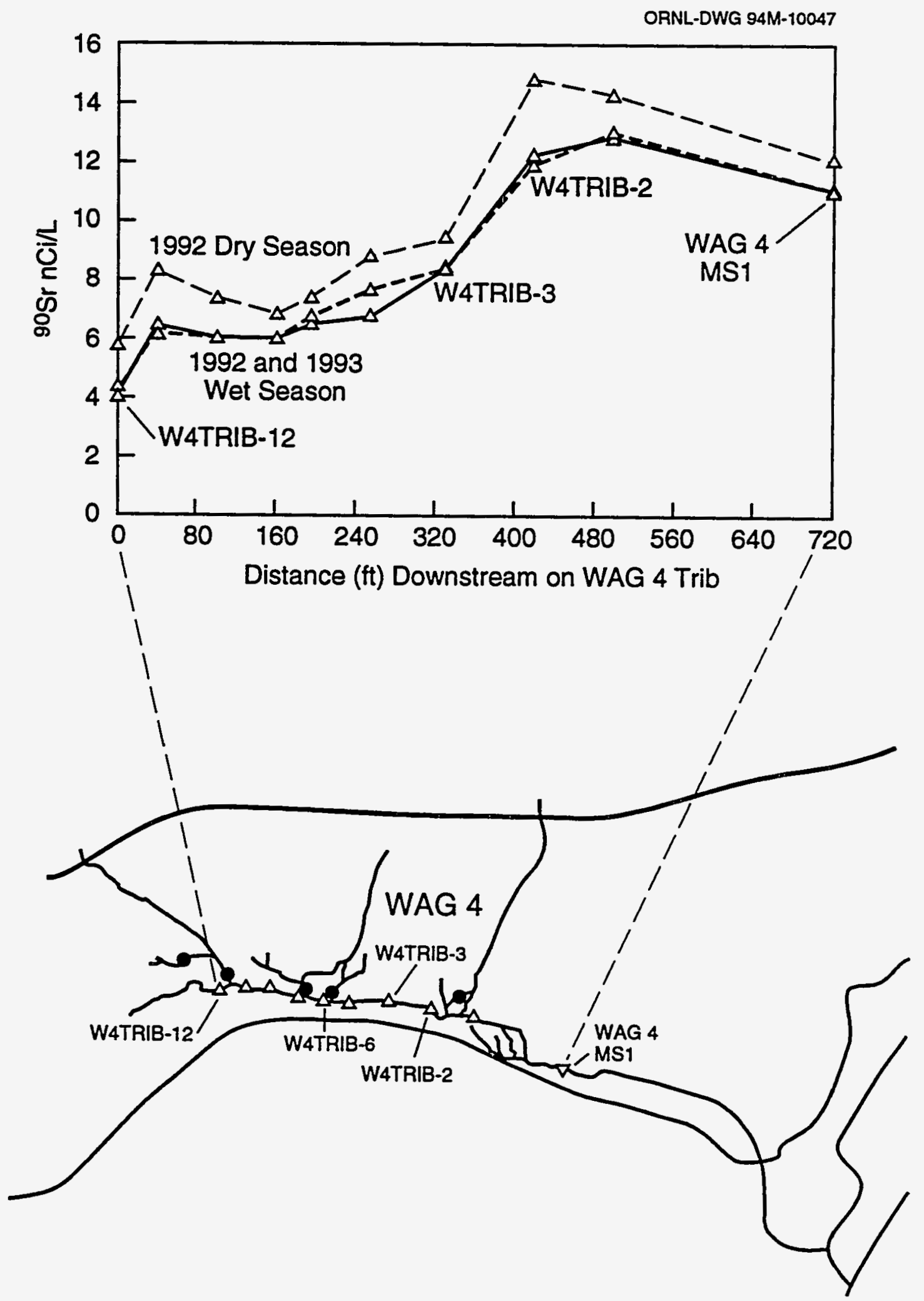

Fig. 2.10. ${ }^{90} \mathrm{Sr}$ results from sampling along a transect of the Waste Area Grouping 4 tributary. Data for 1993 dry season are not yet available. 


\subsubsection{Tributaries}

Both the Seep Task and the Tributary Assessment Task contribute to sampling and monitoring activities for tributaries. Under the Seep Task, ${ }^{3} \mathrm{H}$ and ${ }^{90} \mathrm{Sr}$ fluxes were determined for those locations where streamflow measurements can be made and are shown in Figs. 2.11 and 2.12. Fluxes from Seep Areas A, B, C, and D were estimated using differences in upstream and downstream concentrations and estimated streamflow. These data provide snapshot pictures of the contaminant source areas during different baseflow conditions (wet season, intermediate, and dry season). The contaminant source areas during the post-storm sampling in March were similar to those during baseflow except that the fluxes were greater. The fluxes of ${ }^{3} \mathrm{H}$ and ${ }^{90} \mathrm{Sr}$ at White Oak Dam during the post-storm conditions were approximately $14 \mathrm{Ci} / \mathrm{d}$ and $0.017 \mathrm{Ci} / \mathrm{d}$, respectively. These figures are very similar to the monthly average fluxes for March $(12 \mathrm{Ci} / \mathrm{d}$ and $0.014 \mathrm{Ci} / \mathrm{d}$, respectively) based on the flowproportional composite sampling (Data transfer from OECD, 1994). Fluxes from the wetseason baseflow sampling are at least $50 \%$ less than the monthly average for March, indicating that a significant portion of contaminant transport occurs as a result of storm events. During the dry season, results from the baseflow event correspond closely with the monthly average fluxes at the main stream locations, White Oak Dam, MBWEIR, and WCWEIR suggesting that stormflow during the late summer and early fall has little impact on contaminant transport. (As an example, dry season baseflow fluxes of $0.94 \mathrm{Ci} / \mathrm{d}$ for ${ }^{3} \mathrm{H}$ and $2.2 \mathrm{mCi} / \mathrm{d}$ for ${ }^{90} \mathrm{Sr}$ compare well with monthly averages of $0.88 \mathrm{Ci} / \mathrm{d}$ and $2.4 \mathrm{mCi} / \mathrm{d}$, as measured by Office of Environmental Compliance and Documentation.)

Mass balance calculations for contaminants in the watershed are approximate because of uncertainties associated with analytical results, flow measurements, and environmental variability; however, the data can be used to identify key areas of contaminant inputs to the White Oak Creek watershed. Flux estimations show that WAG 5 is the source for more than $50 \%$ of the ${ }^{3} \mathrm{H}$ flux in the watershed, with most of it coming from Seep Areas A and B and the middle drainage in WAG 5, which is adjacent to Seep Area B (Fig. 2.11). WAGs 4 and 6 are sources of ${ }^{3} \mathrm{H}$ primarily during the wet season. WAGs 1 and 5 are the main sources of ${ }^{90} \mathrm{Sr}$, with WAG 4 being a significant contributor during the wet season (Fig. 2.12). Within WAG 1 more of the ${ }^{90} \mathrm{Sr}$ appears to be coming from the White Oak Creek reach above the confluence with the Northwest Tributary; however, a significant portion also comes from First Creek, which is probably related to discharge from the Corehole 8 plume. Seep Areas C and D associated with WAG 5 are significant source areas for ${ }^{90} \mathrm{Sr}$. Sources in WAG 9 contribute approximately $6 \%$ of the ${ }^{90} \mathrm{Sr}$ flux at White Oak Dam.

In 1994, the WAG 2 Seep Task has continued to work with other ORNL ER efforts to gather data needed to prioritize seeps/source areas for potential early actions and to evaluate the effectiveness of the actions when conducted. Examples of this coordination are: (1) providing data and technical expertise to evaluate whether discrete seep areas exist in WAG 4 that would benefit from an early (removal) action, (2) initiating and carrying out intensive baseline monitoring around Seep Areas C and D where early actions are scheduled for 1994, and (3) collecting samples in White Oak Creek near the WAG 1 impoundments to determine if there is significant contaminant release to the watershed from the impoundments.

The Tributary Assessment Task was initiated in FY 1993 to determine contaminant transport characteristics and to develop $\mathrm{C}-\mathrm{Q}$ relationships from tributaries draining the source WAGs into WAG 2. The assessment of contaminant flux on small tributaries will 


\section{ESTIMATED TRITIUM FLUX (Ci/d)}

ORNL-DWG 94M-10073

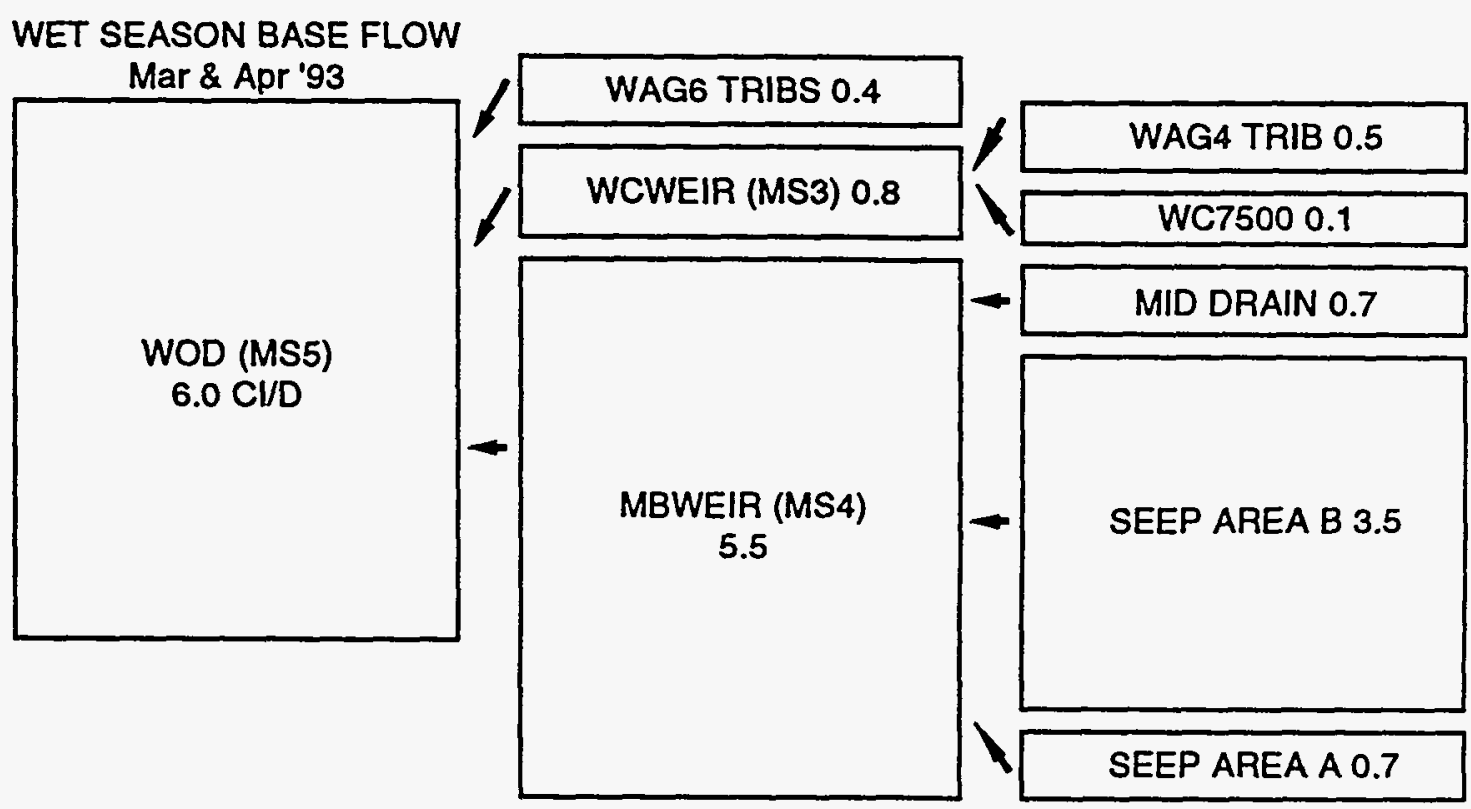

MAY BIMONTHLY BASE FLOW 1

'93

\begin{tabular}{|c|c|c|}
\hline WCWEIR (MS3) 0.5 & WC7500 0.4 \\
W.6Ci/d & MID DRAIN 0.3 \\
MBWEIR (MS4) 2.5 & SEEP AREA 1.3 \\
SEEP AREA A 0.4
\end{tabular}

DRY SEASON BASE FLOW

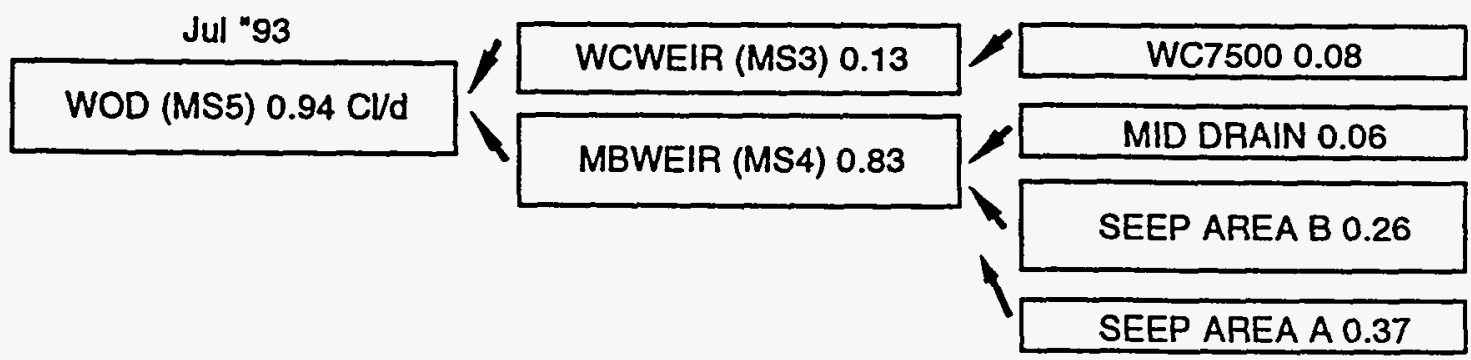

1 WAG6 TRIBS not sampled

Fig. 211. Distribution of tritium fluxes in the White Oak Creek watershed. In cases where upstream sources of contamination (boxes on the right) do not add up to downstream measurements, there are other minor sources of contamination. 


\section{ESTIMATED STRONTIUM-90 FLUX (mCi/d)}
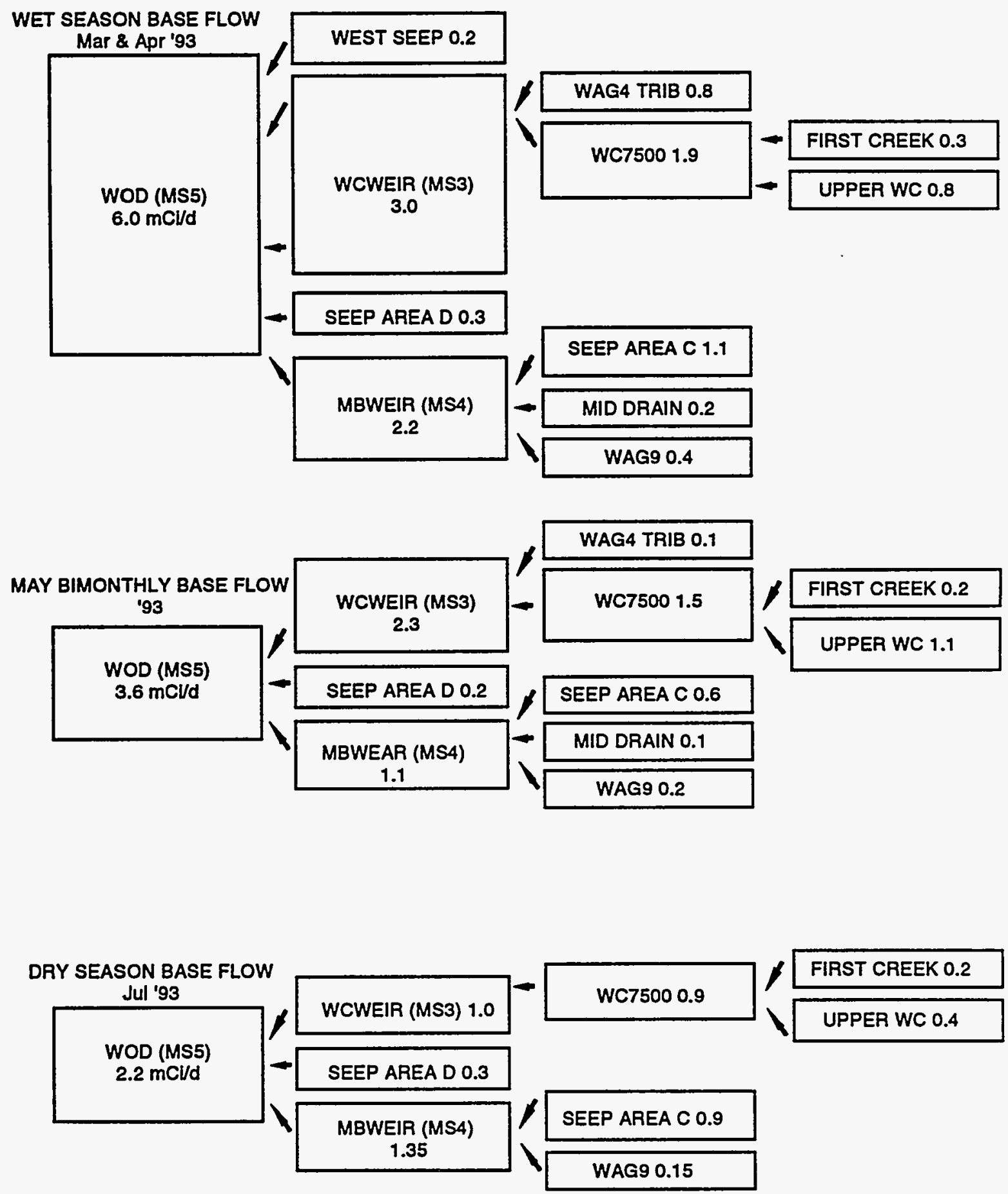

Fig. 2.12. Distribution of ${ }^{90} \mathrm{Sr}$ fluxes in the White Oak Creek watershed. In cases where upstream sources of contamination (boxes on the right) do not add up to downstream measurements, there are other minor sources of contamination. 
support the development of a site-wide perspective on the mobilization and transport of contaminants. These efforts, in coordination with the Seep Task, will lead to decisions on remediation of individual waste trenches and/or remediation of waste on a larger scale. In addition, by establishing baseline $\mathrm{C}-\mathrm{Q}$ relationships, data will be available to evaluate the effectiveness of future remedial methods.

Phase I of the Tributary Assessment Task consisted of collecting grab samples from 17 tributaries (Fig. 2.13) during a wet season storm event to complement the prioritization of sites, from a risk/dose perspective, for subsequent intensive sampling and characterization. Sampling conducted during this phase of the task supplemented the data collection activities of the Seep Task. Seep data consist of baseflow (primarily) and post-storm samples. Storm sampling was conducted to determine the presence of contaminants that may not be present (or are not in detectable quantities) under baseflow or post-storm conditions and to identify sources of greater magnitude during high-flow conditions.

Samples collected during the Tributary Assessment Task Phase I storm event were analyzed for radionuclides $\left({ }^{3} \mathrm{H},{ }^{90} \mathrm{Sr}\right.$, gross alpha and gross beta, ${ }^{137} \mathrm{Cs}$, and $\left.{ }^{60} \mathrm{Co}\right)$ and $\mathrm{ICP}$ metals. At sampling sites equipped with a hydraulic control device (i.e., weir or flume), stage measurements were recorded to calculate discharge and hence mass flux of contaminants. Therefore, these sites can be ranked according to their relative contributions to off-site transport of contaminants (mass flux) as well as by concentration of constituents.

Table 2.2 shows the ranking of sites, from highest to lowest, for ${ }^{3} \mathrm{H}$, soluble ${ }^{90} \mathrm{Sr}$, gross alpha, gross beta, ${ }^{137} \mathrm{Cs}$, and ${ }^{60} \mathrm{Co}$, respectively, based on concentration and mass flux. For each constituent, all sites with measured concentrations statistically above zero, were listed. However, for ${ }^{3} \mathrm{H}$ and gross alpha, two or more sites are not ranked by flux, primarily due to the lack of discharge measurements. In both cases, the sites that are ranked by concentration but not by flux are considered to be grouped together with the lowest rankings (by flux). MS1 and T2A, both located on the tributary draining WAG 4 into White Oak Creek (Fig. 2.3), were ranked first and second (not always in the same order) for each radionuclide (concentration and flux) except for ${ }^{60} \mathrm{Co}$.

Based on the ranking of sites from the Tributary Assessment Task Phase I sampling and previous Seep Task sampling events, automatic streamflow sampling during storms was initiated on three tributaries during the second half of FY 1993. These sites are MS1, HRT, and ESP (Fig. 2.13). In FY 1994, a fourth site, T2A, was also instrumented for intensive sampling of storms. Phase $I I$ of the Tributary Assessment Task will primarily determine baseline $\mathrm{C}-\mathrm{Q}$ relationships for radionuclides of concern (from a risk/dose perspective) for sites contributing significantly to the total risk to human health and the environment. In addition, secondary objectives are to:

1. calculate annual fluxes of contaminants from source WAGs contributing to off-site release,

2. support the decision-making process for prioritization of sites for remediation, and

3. support the future evaluation and verification of the effectiveness of remedial actions. During the latter part of FY 1993 through the middle of FY 1994, several sampling events have been conducted for the Tributary Assessment Task Phase II effort. An early dry season storm (Storm A) was intensively sampled in May 1993 at the three sites 


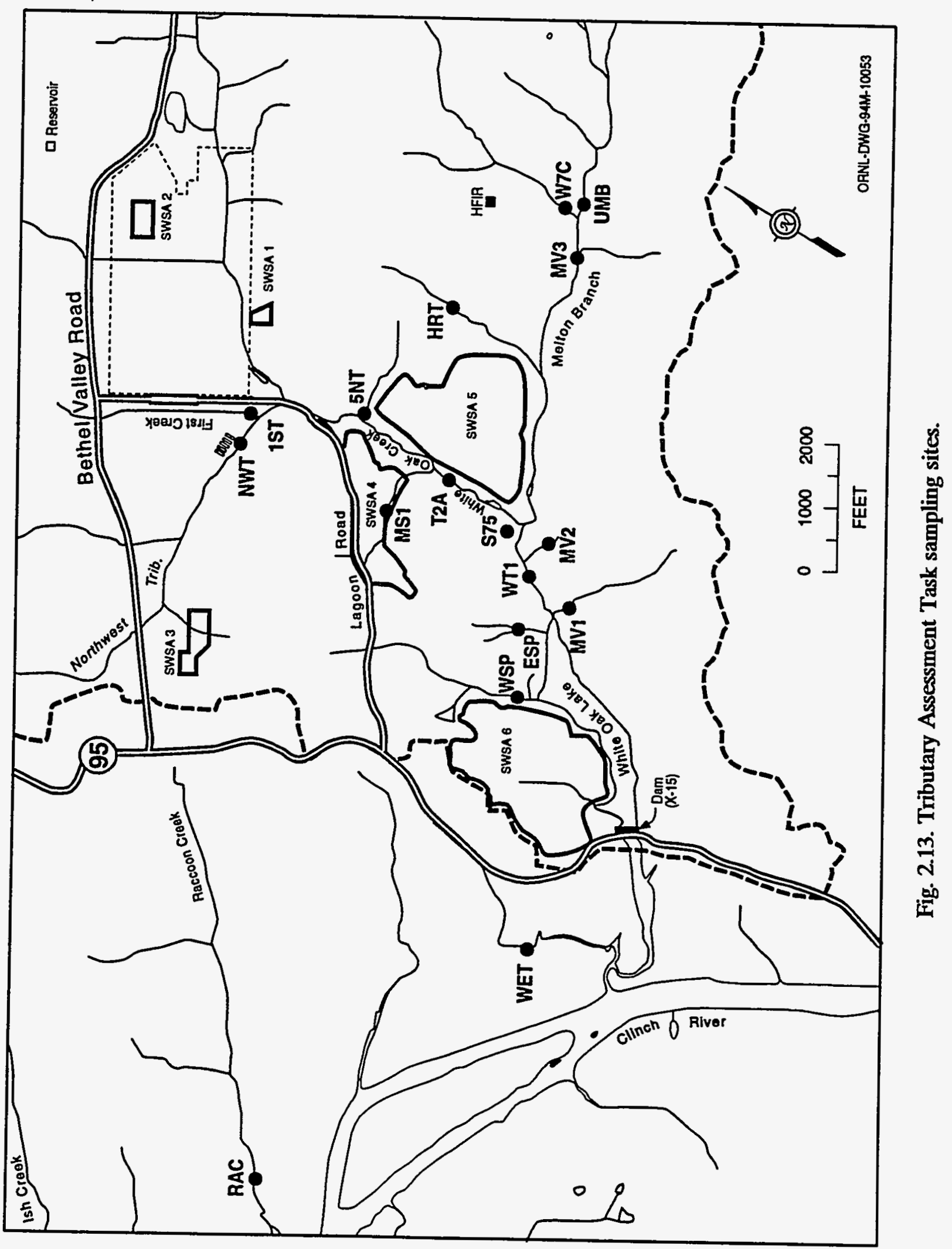


Table 2.2. Ranking of Tributary Assessment Task Phase I sites for ${ }^{3} \mathrm{H},{ }^{90} \mathrm{Sr}$, gross alpha, gross beta, ${ }^{137} \mathrm{Cs}$, and ${ }^{60} \mathrm{Co}$ based on concentration and flux

\begin{tabular}{|c|c|c|c|c|c|c|c|c|c|c|c|c|}
\hline Ranking & $\begin{array}{l}{ }^{3} \mathrm{H} \\
\text { Conc. }\end{array}$ & $\begin{array}{c}{ }^{3} \mathrm{H} \\
\text { Flux }^{1}\end{array}$ & $\begin{array}{l}{ }^{90} \mathrm{Sr} \\
\text { Conc. }\end{array}$ & $\begin{array}{l}{ }^{90} \mathrm{Sr} \\
\text { Flux }\end{array}$ & $\begin{array}{l}\text { Gross } \\
\text { Alpha } \\
\text { Conc. }\end{array}$ & $\begin{array}{c}\text { Gross } \\
\text { Alpha } \\
\text { Flux }\end{array}$ & $\begin{array}{c}\text { Gross } \\
\text { Beta } \\
\text { Conc. }\end{array}$ & $\begin{array}{l}\text { Gross } \\
\text { Beta } \\
\text { Flux }\end{array}$ & $\begin{array}{l}{ }^{137} \mathrm{Cs} \\
\text { Conc. }\end{array}$ & $\begin{array}{l}{ }^{137} \mathrm{Cs} \\
\text { Flux }\end{array}$ & $\begin{array}{l}{ }^{60} \mathrm{Co} \\
\text { Conc. }\end{array}$ & $\begin{array}{l}{ }^{60} \mathrm{Co} \\
\text { Flux }\end{array}$ \\
\hline 2 & $\mathrm{~T} 2 \mathrm{~A}$ & MS1 & $\mathrm{T} 2 \mathrm{~A}$ & MS1 & $\mathrm{T} 2 \mathrm{~A}$ & $\mathrm{~T} 2 \mathrm{~A}$ & $\mathrm{~T} 2 \mathrm{~A}$ & $\mathrm{~T} 2 \mathrm{~A}$ & MS1 & MS1 & ESP & S75 \\
\hline 3 & S75 & WSP & HRT & HRT & ESP & HRT & HRT & HRT & HRT & HRT & & \\
\hline 4 & ESP & NWT & 1ST & $1 \mathrm{ST} / \mathrm{WSP}$ & $\mathrm{S} 75$ & WSP & S75 & WSP & ESP & WSP & & \\
\hline 5 & WSP & RAC & WSP & & HRT & ESP & ESP & 1ST & S75 & $1 S T$ & & \\
\hline 6 & WT1 & ESP & UMB & & WSP & $1 S T$ & WT1 & NWT & WT1 & NWT & & \\
\hline 7 & W7C & $\mathrm{HRT}^{2}$ & & & WT1 & S75 & WSP & ESP & $1 \mathrm{ST} / \mathrm{WSP}^{4}$ & RAC & & \\
\hline 8 & MV2 & S75 & & & MV1 & & $1 \mathrm{ST}$ & S75 & RAC & ESP & & \\
\hline 10 & NWT & & & & & & & & & WT1 & & \\
\hline 11 & MV3 & & & & & & & & & & & \\
\hline 12 & $5 \mathrm{NT}$ & & & & & & & & & & & \\
\hline 13 & WET & & & & & & & & & & & \\
\hline 14 & HRT & & & & & & & & & & & \\
\hline 15 & $\mathrm{RAC}$ & & & & & & & & & & & \\
\hline 16 & UMB & & & & & & & & & & & \\
\hline 17 & 1ST & & & & & & & & & & & \\
\hline
\end{tabular}

'Discharge measurements made at all sites listed except RAC and S75. Discharge estimates (for flux calculations) for these sites are based on drainage areas and observations. ${ }^{2}$ Discharge values at $1 S T$ and HRT are high relative to sites ranked higher by concentration.

${ }^{3}$ Two samples (one a duplicate) were collected at WSP. One value of flux is higher than at 1ST and the other is lower.

${ }^{4}$ Concentration at 1 ST and WSP are nearly equal. 
initially instrumented as described above. For this storm event, samples were analyzed for radionuclides only $\left({ }^{3} \mathrm{H},{ }^{90} \mathrm{Sr}\right.$, gross alpha, gross beta, ${ }^{137} \mathrm{Cs}$, and $\left.{ }^{60} \mathrm{Co}\right)$. Subsequently, all four sites were sampled for wet season storms in late January (Storm D) and early March (Storm E) of 1994. For these storm events, samples were analyzed for radionuclides, metals, anions, and alkalinity. Two minor storm events (Storms B and C) were sampled in early January and subsequently most of the samples were discarded in favor of analyzing samples from the late January and early March storms. However, several samples from each of these storms were analyzed for primary radionuclides $\left({ }^{3} \mathrm{H}\right.$ and ${ }^{90} \mathrm{Sr}$ ). For storm events $\mathrm{A}, \mathrm{D}$, and E, samples were collected across the full range of discharges measured at each site. In addition, several baseflow samples have been collected at each of the four intensive sampling sites in order to develop the low-flow portion of the C-Q relationship.

Figures 2.14 and 2.15 show ${ }^{3} \mathrm{H}$ and ${ }^{90} \mathrm{Sr}$ concentration $(C)$ versus discharge $(\mathrm{Q})$ data, respectively, for samples collected from MS1 on the tributary draining WAG 4 to White Oak Creek for storms A and D. Preliminary C-Q relationships have been developed independently for each storm for both ${ }^{3} \mathrm{H}$ and ${ }^{90} \mathrm{Sr}$ because two distinct correlations appear to exist for both radionuclides: a wet season and a dry season relationship. In addition, for ${ }^{3} \mathrm{H}$ and ${ }^{90} \mathrm{Sr}$, in winter the $\mathrm{C}-\mathrm{Q}$ relationship produces higher concentrations, and hence higher fluxes, for a given discharge than the $C-\mathrm{Q}$ relationship in summer. However, it appears that there may be more variability (spread) in the ${ }^{3} \mathrm{H}$ than in the ${ }^{90} \mathrm{Sr}$ data.

Using the preliminary $\mathrm{C}-\mathrm{Q}$ relationships developed for ${ }^{3} \mathrm{H}$ and ${ }^{90} \mathrm{Sr}$, and annual discharge data for 1993, annual fluxes from MS1 were calculated (estimated) for the two radionuclides and compared to the fluxes (source terms) estimated for the Middle White Oak Creek Reach (Sect. 2.4.4). The WAG 4 tributary is the primary contributor of ${ }^{3} \mathrm{H}$ and ${ }^{90} \mathrm{Sr}$ to White Oak Creek along this reach. In order to most effectively apply both $\mathrm{C}-\mathrm{Q}$ relationships to the flux calculations for each radionuclide, the winter/wet season was chosen to be 6 months (JanuaryApril and November-December) and the remainder of the year was designated the summer/dry season. The discharge data for these periods of time were matched with the respective $\mathrm{C}-\mathrm{Q}$ relationships to calculate contaminant flux for the three periods. Annual (1993) fluxes of ${ }^{3} \mathrm{H}$ and ${ }^{90} \mathrm{Sr}$ from MS1 were estimated to be $396 \mathrm{Ci}$ and $0.490 \mathrm{Ci}$, respectively. The source terms for ${ }^{3} \mathrm{H}$ and ${ }^{90} \mathrm{Sr}$ in the Middle White Oak Creek Reach are 284 and 0.236 $\mathrm{Ci}$, respectively. These preliminary MS1 flux estimates represent discrepancies of at least 39\% for ${ }^{3} \mathrm{H}$ and $108 \%$ for ${ }^{90} \mathrm{Sr}$ which suggests that WAG 4 may be a larger source than previously believed. However, data from additional storm events and subsequent relationships developed for T2A, at the confluence of the WAG 4 tributary and White Oak Creek, are needed to resolve these differences.

These data show the variation of concentration both within a storm and throughout the annual cycle of wet and dry seasons. In FY 1995, these data will assist staff in the development of an early action for WAG 4 designed to reduce the ${ }^{90} \mathrm{Sr}$ input to the White Oak Creek system.

The data in this section are obtained from the quarterly environmental surveillance reports for 1993 (Goldberg et al. 1993 a, b for the first half year) and computer transfer of data (for the remainder of the year). 


\section{MS1 Tritium Results}

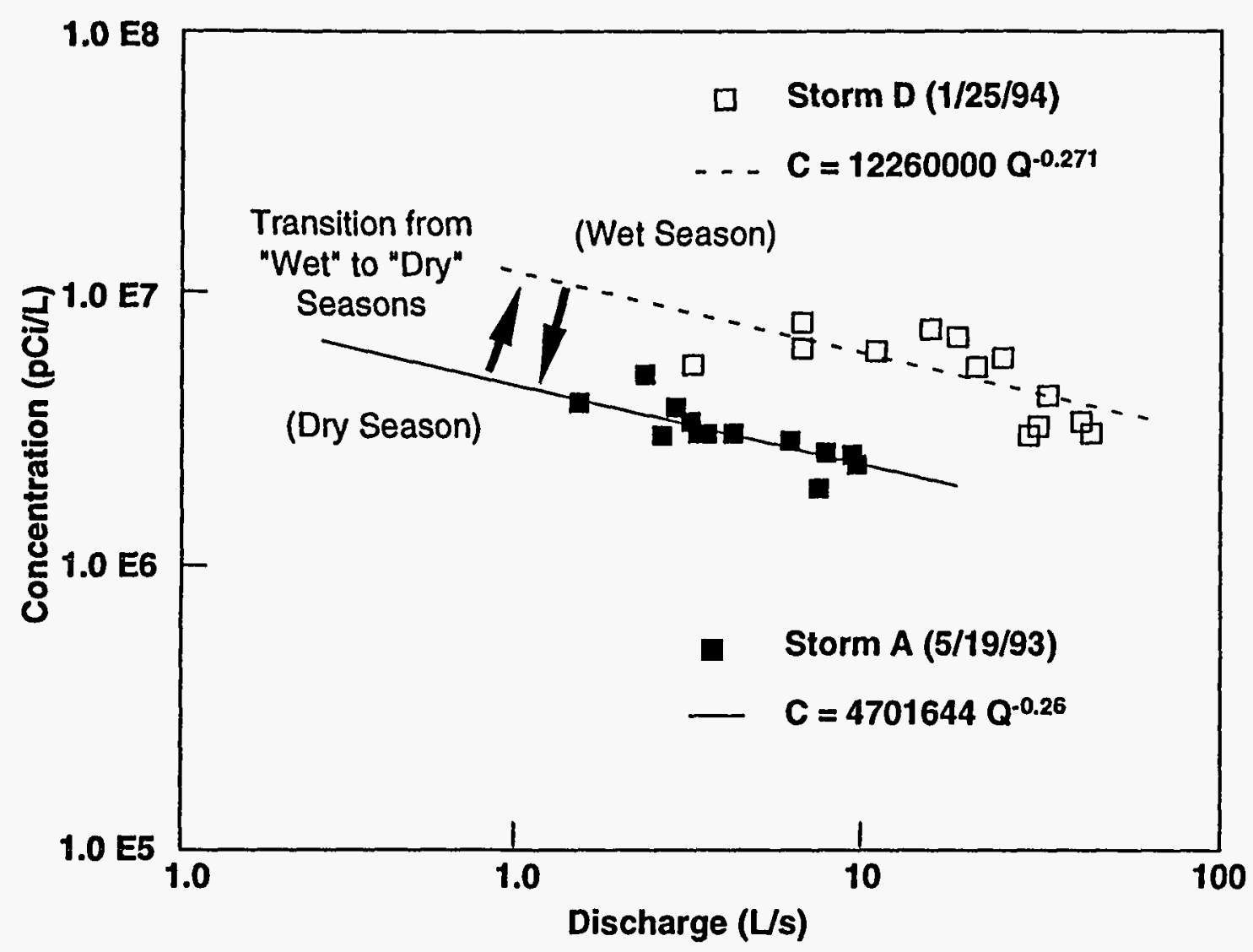

Fig. 2.14. Tritium concentration (C) vs discharge (Q) for samples collected from MS1 on the tributary draining Waste Area Grouping 4 to White Oak Creek for storms $A$ and D. Regressions determined by least-squares fit to the data points shown. 


\section{MS1 Strontium-90 Results}

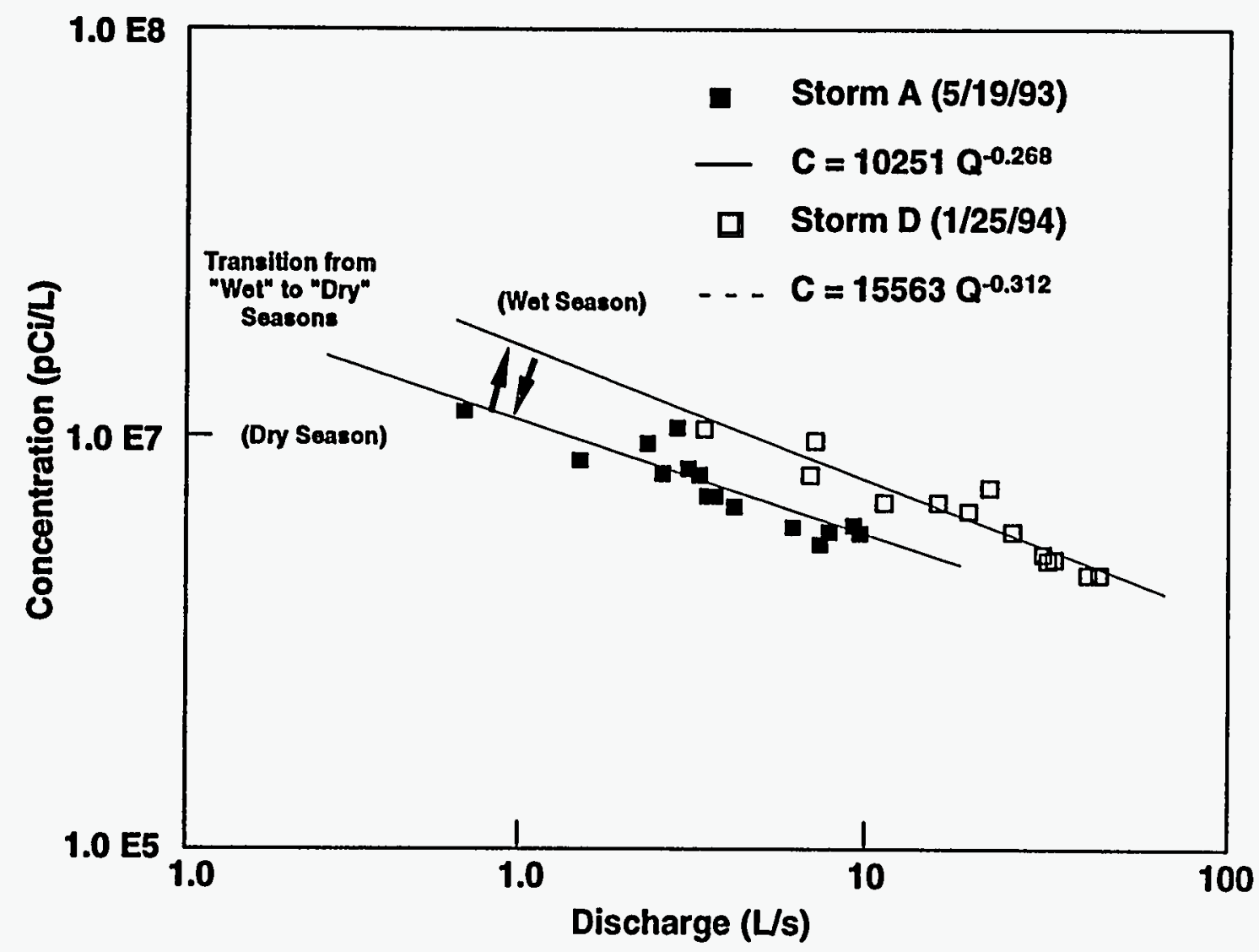

Fig. 2.15. Strontium-90 concentration (C) vs discharge (Q) for samples collected from MS1 on the tributary Waste Area Grouping 4 to White Oak Creek for storms A and D. Regressions determined by least-squares fit to the data points shown. 


\subsection{Nonradiological Contaminant Discharge}

Concentrations of metals, anions, and other contaminant indicators measured at the Environmental Surveillance and Protection Section of Office of Environmental Compliance and Documentation surface water monitoring stations MBWEIR, WOCWEIR, and White Oak Dam were compared to averages of reference values calculated from data collected at upgradient stations at Melton Hill Dam and in White Oak Creek headwaters. Constituent concentration averages that exceed the reference location averages by more than $35 \%$ are considered as elevated over the reference value, as reported in Energy Systems (1992). At MBWEIR, WOCWEIR, and White Oak Dam, excess sulfate, fluoride, and zinc were detected. In addition, at White Oak Dam, the final release point from the Oak Ridge Reservation, excess chromium, aluminum, iron, manganese, total organic carbon, oil and grease, phosphorus, and total dissolved solids were detected. White Oak Creek results are comparable with those at White Oak Dam, but MBWEIR metals are more like those found in the reference waters. With respect to organic contaminants, very low analytical values are suspect; therefore a value five times the analytical detection limit was used as a nominal rule by the Environmental Surveillance and Protection Section for assessing the presence of organics. Based on this criterion, no significant organic contamination was found at the three Environmental Surveillance and Protection Section ambient surface-water stations.

\subsubsection{Radionuclide Fluxes at Main Stations}

For radiological monitoring within the White Oak Creek watershed, sampling locations are WOCWEIR, MBWEIR, 7500 Bridge, First Creek, Northwest Tributary, Fifth Creek, Middle Melton Branch (MB2), WOC Headwaters (background monitoring), and White Oak Dam. Figures A.1-A-8 in Appendix A show the monthly fluxes during 1993 for ${ }^{3} \mathrm{H}$, total strontium, ${ }^{137} \mathrm{Cs}$, and ${ }^{60} \mathrm{Co}$, respectively, for Middle White Oak Creek and lower White Oak Creek/White Oak Dam, respectively. Total strontium is the sum of ${ }^{89} \mathrm{Sr}$ and ${ }^{90} \mathrm{Sr}$; and the calculated fluxes at Melton Branch were corrected for submergence at the monitoring weir. Continuous flow-proportional sampling for the stations at Middle White Oak Creek Reach and Lower White Oak Creek/White Oak Lake Reach allows mass balances to be computed. Accumulation or loss of material is calculated by

$$
\text { Source or sink = flux out }- \text { flux in, }
$$

where a positive value means that the reach is a source; that is, the radionuclide is either being mobilized within the reach or added to the reach by unmeasured inflow from tributaries or groundwater. A negative value, indicating a sink, means that the reach is accumulating radionuclides, either by deposition (particle-bound contaminants can be deposited) or by some uptake mechanism. Of course, the mass balance is a spatial average; therefore, a radionuclide can increase/accumulate in some areas while it is simultaneously mobilized from other areas within a given reach.

The source/sink estimates are considered to be provisional because there are several sources of uncertainty. Because the source/sink factor is the difference between two uncertain values, the uncertainty can be magnified. Furthermore, negative values, indicating a contaminant sink, for soluble contaminants ${ }^{3} \mathrm{H}$ and total strontium are suspect because of the chemistry of these radionuclides. 
During 1993, as in 1992, the monthly radionuclide fluxes generally show a seasonal trend. As shown for the soluble contaminants ${ }^{3} \mathrm{H}$ and total strontium (Figs. A-1 and $\mathrm{A}-2$, respectively), the minimum monthly fluxes occurred in September or October when conditions were the driest, and the maximum monthly fluxes occurred in January, March, and December, when runoff was greatest.

Although ${ }^{137} \mathrm{Cs}$ shows some similarities, the ${ }^{137} \mathrm{Cs}$ flux at Middle White Oak Creek Reach appears to be more randomly distributed, perhaps influenced more strongly by individual storms. In addition, there is no distinct relationship between ${ }^{137} \mathrm{Cs}$ flux at 7500 Bridge and at WOCWEIR. The ${ }^{137} \mathrm{Cs}$ flux at White Oak Dam was highest in March and lowest in July, however, at WOCWEIR it was low in March and much higher in July (Fig. A-7). During 1992, lower White Oak Creek and White Oak Lake acted as a source of ${ }^{137} \mathrm{Cs}$ during the wet, non-growing season (winter) and as a sink during the dry, growing season (summer) (ERMA 1993). For the current reporting period, lower White Oak Creek and White Oak Lake acted as a source of ${ }^{137} \mathrm{Cs}$ only during the months of January, March, and August, and most significantly in March. During every other month except May, lower White Oak Creek and White Oak Lake acted as a sink for a net loss of approximately $0.6 \mathrm{Ci}$. It appears that ${ }^{137} \mathrm{Cs}$ discharge from White Oak Dam is somewhat independent of input from White Oak Creek and more dependent on seasonal factors and individual storm characteristics.

In 1991 and 1992, maximum ${ }^{60} \mathrm{Co}$ fluxes at White Oak Dam tended to occur 1-2 months after peak monthly flows. However, this pattern was more prevalent in 1991 than in 1992 . For the current reporting period (1993), this pattern no longer prevails, and ${ }^{60} \mathrm{Co}$ fluxes roughly follow seasonal trends of higher discharges during wet months and lower discharges during dry months (Fig. A-8). WAG 7 is the major source of ${ }^{60} \mathrm{Co}$, which enters White Oak Creek through two primary pathways: a groundwater seep (cobalt seep) that drains to an ungaged tributary and a small gaged tributary (ESP) draining multiple diffuse seeps to White Oak Creek. Perhaps the character of one or more of these seeps is changing over time making the groundwater response to ${ }^{60} \mathrm{Co}$ less delayed relative to surface-water discharge.

Table 2.3 lists the annual mass balances for radionuclides for the Middle White Oak Creek Reach and the Lower White Oak Creek/White Oak Lake Reach. Middle White Oak Creek Reach is a source for ${ }^{3} \mathrm{H}$ and total strontium, and the main source for both radionuclides in this reach is known to be a small unnamed tributary draining WAG 4 (Figs. 2.5-2.6). The mass balances also indicate that the reach accumulated ${ }^{60} \mathrm{Co}$ and was a sourceof ${ }^{137} \mathrm{Cs}$ during the year. The old intermediate pond area on White Oak Creek along this reach is known to be contaminated with ${ }^{137} \mathrm{Cs}$. The source/flux ratio for the Middle White Oak Creek Reach is $0.83,0.28,0.12$, and -1.93 for ${ }^{3} \mathrm{H}$, total strontium, ${ }^{137} \mathrm{Cs}$, and ${ }^{60} \mathrm{Co}$, respectively. The values (absolute) are judged to be large for ${ }^{3} \mathrm{H}$, total strontium, and ${ }^{60} \mathrm{Co}$,

For the Lower White Oak Creek/White Oak Lake Reach, the pattern is reversed for ${ }^{3} \mathrm{H}$, which appears to be accumulating in the reach. This does not make sense because it is not plausible to accumulate ${ }^{3} \mathrm{H}$, which is water soluble. The source/flux ratio is small $(-0.10)$, suggesting uncertainty of sink vs source. The problem lies with errors associated with discharge measurements or flow-paced sampling. These errors do not invalidate the flux measurements themselves. 
Table 2.3. Annual fluxes and mass balances for radionuclides in WAG 2 for 1993

\begin{tabular}{|c|c|c|c|c|c|c|c|c|c|c|c|c|c|c|}
\hline \multirow[t]{2}{*}{ REACH } & \multirow[t]{2}{*}{ WEIR } & \multirow[t]{2}{*}{$\begin{array}{c}\text { AVG. } \\
\text { DISCHARGE } \\
\text { (L/s) }\end{array}$} & \multicolumn{4}{|c|}{$\begin{array}{c}\text { AVERAGE } \\
\text { CONCENTRATION } \\
\text { (PCi/L) }\end{array}$} & \multicolumn{4}{|c|}{$\begin{array}{l}\text { DISCHARGE } \\
\text { (Ci) }\end{array}$} & \multicolumn{4}{|c|}{$\begin{array}{c}\text { SOURCE }(+) \text { or } \operatorname{SINK}(-) \\
\text { (Ci) }\end{array}$} \\
\hline & & & ${ }^{3} \mathbf{H}$ & $\mathrm{Sr}^{1}$ & ${ }^{137} \mathrm{Cs}$ & ${ }^{60} \mathrm{Co}$ & ${ }^{3} \mathbf{H}$ & $\mathrm{Sr}^{1}$ & ${ }^{137} \mathrm{Cs}$ & ${ }^{60} \mathrm{Co}$ & ${ }^{3} \mathrm{H}$ & $\mathrm{Sr}^{1}$ & ${ }^{137} \mathrm{Cs}$ & ${ }^{60} \mathrm{Co}$ \\
\hline & $7500 \mathrm{BR}$. & 259 & & 75 & 120 & 2.2 & 58 & 0.61 & 0.99 & & & & & \\
\hline & WOCWEIR & 272 & 4000 & 98 & 130 & 2.2 & 340 & 0.84 & 1.12 & 0.019 & & & & \\
\hline Middle & & & & & & & & & & & 280 & 0.24 & +0.13 & -0.037 \\
\hline & MBWEIR & 9 & 7700 & 410 & 11 & 4.9 & 1700 & 0.88 & 0.025 & 0.011 & & & & \\
\hline & WO DAM & 352 & 1600 & 190 & 48 & 4.1 & 1800 & 2.1 & 0.53 & & & & & \\
\hline Lower WOC & & & & & & & & & & & -180 & 0.41 & -0.61 & 0.016 \\
\hline
\end{tabular}

${ }^{1}$ Total strontium $={ }^{89} \mathrm{Sr}+{ }^{90} \mathrm{Sr}$. 
Lower White Oak Creek/White Oak Lake is a source for total strontium, although the source/flux ratio is relatively small $(0.19)$. The reach was also a source for the discharge of ${ }^{60} \mathrm{Co}$ at White Oak Dam during 1993. Because of the cobalt seep and other seeps in WAG 7 that drain to lower White Oak Creek/White Oak Lake, it is not surprising that this reach is a source for ${ }^{60} \mathrm{Co}$. In contrast, the fluxes from seeps and tributaries known to be contaminated with ${ }^{137} \mathrm{Cs}$ are judged to be small; therefore, it is not surprising that this reach was a sink for ${ }^{137} \mathrm{Cs}$ in 1993 . However, in 1992 , this reach acted as a source of ${ }^{137} \mathrm{Cs}$ to the embayment. The 1992 data have suggested that the lower White Oak Creek/White Oak Lake Reach is a source of ${ }^{137} \mathrm{Cs}$ during the winter and a sink during the summer. The data for 1993 may conform more closely to our previously accepted knowledge that White Oak Lake has been accumulating contaminated sediments over the years but also confounds the issue when compared with 1992 data.

Total contaminant discharges at White Oak Dam are similar to those reported for 1991 and 1992 (ERMA 1992, 1993) except for the ${ }^{3} \mathrm{H}$ discharge which has decreased from 2100 to $1800 \mathrm{Ci}$. This decrease resulted in the reduced contribution to risk of ${ }^{3} \mathrm{H}$ relative to ${ }^{90} \mathrm{Sr}$, as reported in Sect. 6.2.1.

\subsection{CONTAMINANT FLUX DYNAMICS}

The flux of contaminants within the White Oak Creek watershed is highly dynamic. Any temporal pattern of contaminant discharges to the White Oak Creek system and off-site is important because the pattern or trend could affect sampling results, reveal physical mechanisms whereby contaminants are mobilized, and affect the design of remedial actions. It is important to identify trends in both contaminant concentrations and contaminant fluxes in the streams at ORNL.

Past ERMA reports showed that during storms contaminant concentrations tend to decrease (dilution) with increasing streamflow. In contrast, monthly data generally do not show this relationship; instead, concentration tends to increase with increasing flow, as shown in Fig. 2.16. In this section this apparent difference is addressed, and the conceptual model of contaminant transport in the watershed is extended to include both short-term storm responses and longer-term seasonal responses.

\subsubsection{Storm Response}

The C-Q relationships for ${ }^{3} \mathrm{H}$ and ${ }^{90} \mathrm{Sr}$ shown in Figs. 2.14 and 2.15 show the partial dilution of contaminants that occurs during storms. These relationships conform to the hydrologic conceptual model in Sect. 2.3. Figures 2.14 and 2.15 also show the systematic changes that occur between storms where the concentrations during the wet season are greater than those during the dry season. This seasonal difference in the average concentrations during the storms probably results in the higher concentrations observed during larger discharges (Fig. 2.16). This seasonal variation is addressed in this section.

\subsubsection{Seasonal Response}

Figure 2.17a is a plot of the cumulative strontium fluxes at the main gaging stations on White Oak Creek watershed over a period of 6.5 years. The figure shows the positive slope typical of a cumulative plot. It also shows a cyclic pattern from year to year consisting of a 


\section{ORNL-DWG 94M-10081 \\ White Oak Creek}

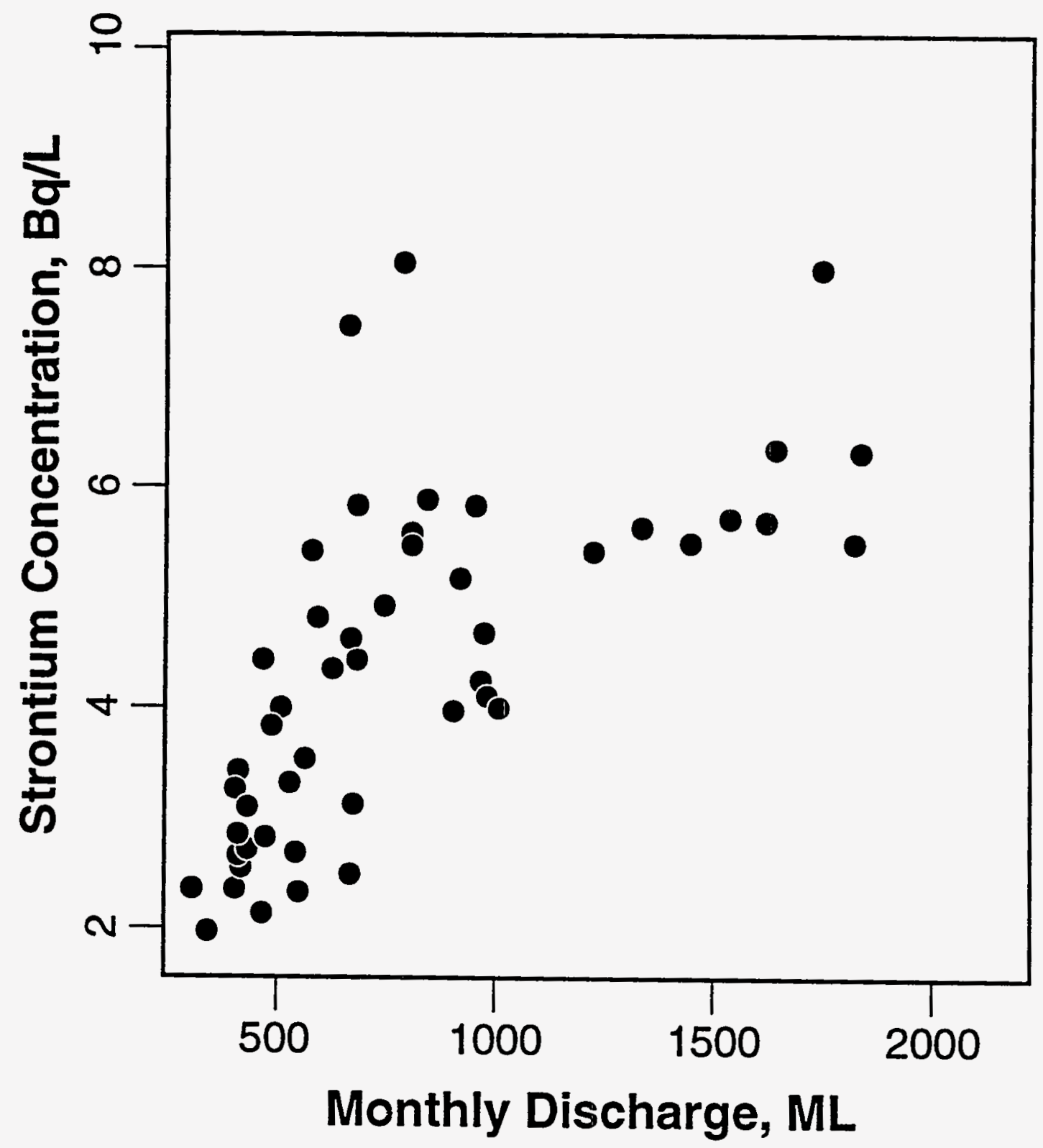

Fig. 2.16. Total radioactive strontium concentration vs discharge for monthly flow proportional data at White Oak Creek. Despite the scatter of the data, the positive correlation in the data is probably due to the increased average concentrations during winter storms when flows are relatively large. $(1 \mathrm{~Bq} / \mathrm{L}=27 \mathrm{pCi} / \mathrm{L})$ 

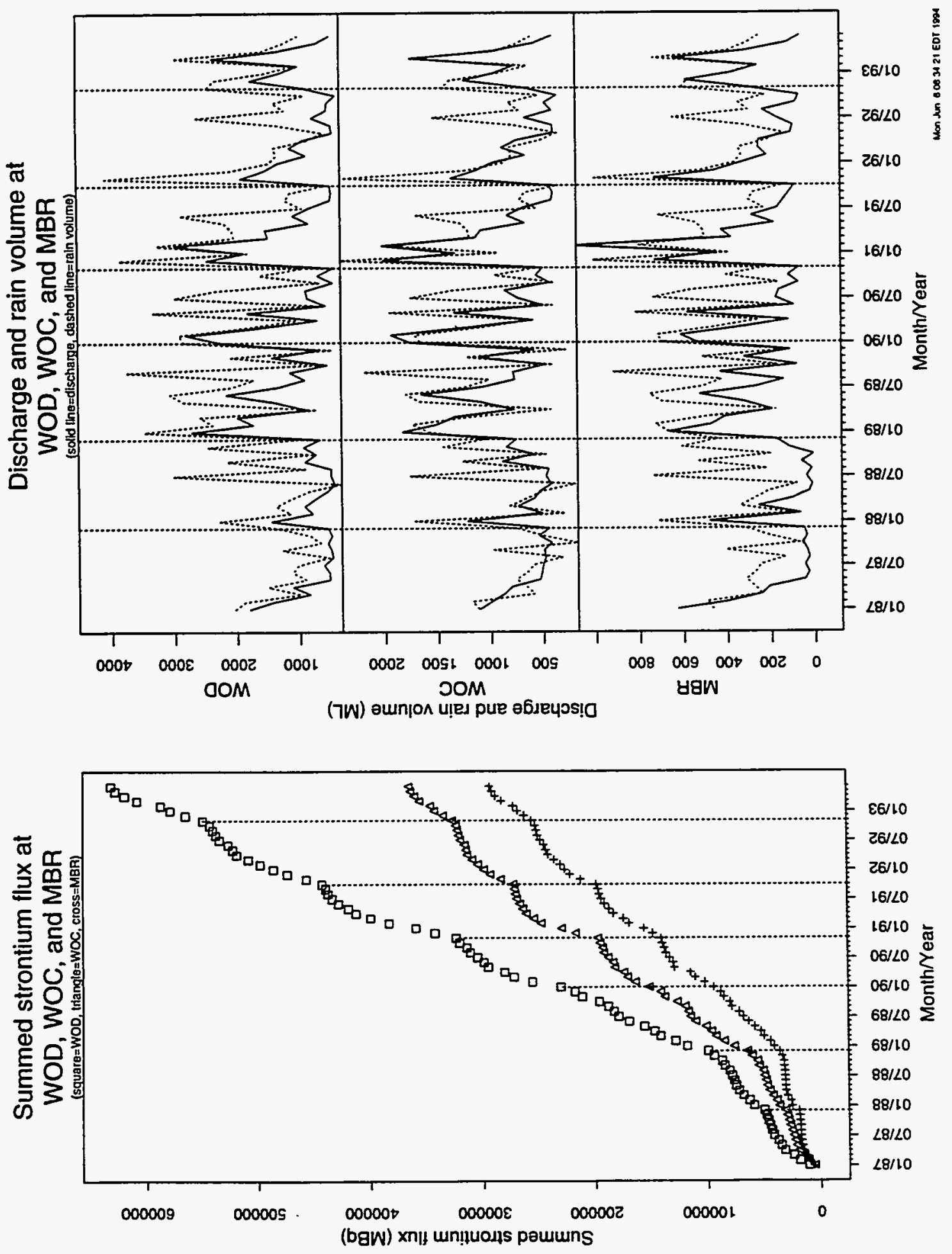
relatively high initial rate in flux that coincides with the beginning of the wet season; thereafter, the monthly contaminant flux diminishes during the spring and into the summer. The contaminants appear to be flushed from the system from midwinter through the summer and early fall. The reduction in flux through the year is not just related to the reduction in streamflow. There is a corresponding decrease in monthly mean concentrations, as implied by the positive correlation in Fig. 2.16. The annual cycle begins with the annual jump in the cumulative flux, identified in Fig. 2.17a by the vertical references lines, marking the beginning of the wet season. This transition month differs from year to year, ranging from October to January.

The annual jump in flux is correlated with a change in the hydrologic state of the watershed. Fig. $2.17 \mathrm{~b}$ shows the time series of stream discharges for the three main basins. Rain volume (computed as the product of precipitation measured at gage SW7 and basin area) is also shown in Fig. $2.17 \mathrm{~b}$; consequently, these time series show the annual water balance in its simplest form. During the wet part of the year, monthly precipitation (P) roughly tracks the runoff $(Q)$ (i.e., $Q \approx P$ ), but during the dry season the discharge is less than precipitation $(\mathrm{Q}<\mathrm{P})$ due to evapotranspiraton.

The vertical reference lines indicating the months of the year when the contaminant fluxes suddenly increase are reproduced in Fig. $2.17 \mathrm{~b}$. The water-balance plots show that the rapid increase in contaminant flux occurs in the late fall or early winter after the condition $(\mathrm{Q}<\mathrm{P})$ has ended. In hydrologic terms, the increased contaminant flux occurs when the autumn/winter rain has filled the groundwater storage; thus high groundwater levels during the wet season are associated with large contaminant fluxes, as discussed in earlier ERMA reports $(1992,1993)$.

The cumulative flux plots also show discrete changes with the onset of the dry season $(\mathrm{Q}<\mathrm{P})$ each year although the change in the contaminant flux is more subtle than the wet season transition.

The shape of the cumulative flux cycle and the relationship between the increase in contaminant flux and the water balance are consistent between the drought years of 1987 and 1988 and the cycles later in the data record, except for a change in the slope of the cumulative flux plot which is smaller during the drought. This uniformity in the pattern suggests that the transition from dry to wet season, as represented by monthly data, can be used as a reliable benchmark in the cycle of a water year as it relates to contaminant transport.

Lastly, the jump in flux occurs simultaneously at all of the monitoring stations in the White Oak Creek watershed, and has been noted for stations that are not shown here. This result is important because it suggests that the phenomenon is reliable at different scales and locations.

\subsubsection{Implications to Environmental Restoration}

The integrated conceptual model links the contaminant transport of tributaries during storms to the long-term monthly contaminant discharge record measured at the major monitoring stations. Key concepts include: 
- Mean concentration discharged during storms exhibits a seasonal variation that is also apparent in the 7-year record of the monthly contaminant discharge record.

- The large increase in the monthly contaminant flux occurs in the late autumn or early winter when the groundwater storage becomes filled and $Q \approx P$. Contaminant flux decreases during the spring and summer when $Q<P$. The change in groundwater storage status is a benchmark in the annual water cycle at ORNL.

- This observation implies that groundwater levels could be indicators of contaminant flux, as also observed in regression analysis in previous ERMA reports.

- The relationships between contaminant flux, precipitation, stream discharge, and groundwater storage appear to be robust. These patterns have been observed over both wet and dry years and across a range of spatial scales. The patterns apply to both ${ }^{90} \mathrm{Sr}$ and ${ }^{3} \mathrm{H}$.

- As mathematical models of contaminant flux related to basic hydrologic parameters are developed, they can be used for performance assessment of remedial actions. Observed fluxes after remedial actions have been constructed can be compared to simulated fluxes based on relationships developed for the 7-year record.

- The integrated conceptual model demonstrates the value of the long-term flowproportional monitoring at surface water stations. This monitoring provides the basis for performance assessment at the watershed scale.

- The conceptual model implies that further data collection in surface water systems must be integrated with groundwater observations. ER will benefit from this integrated approach by the enhancement of our basic understanding of contaminant transport and the development of improved performance assessment tools.

\subsection{SUMMARY}

At the ORNL site, surface water transports contamination that has seeped to the land surface. Surface water erodes and transports contaminated sediments, and deposits those sediments downstream - potentially causing exposures to people and biota. The Surface Water Task includes a variety of data collection programs to determine the distribution, type, and discharge rates of contamination that moves through the ORNL drainage system. Results from the Seep Task and the Tributary Assessment Task support the site-wide prioritization efforts by ER staff described in Sect. 2 and the GW OU investigations described in Sect. 4. Precipitation and stream discharge data support the Sediment Transport Task in Sect. 5 and engineering design of remedial actions. The data collection activities are aimed at the seep, tributary, and watershed scales.

According to the ORNL site conceptual hydrologic model, seeps offer the best opportunity to monitor shallow groundwater because subsurface fracture flow mostly bypasses monitoring wells; therefore, seep sampling is extensive in the WAG 2/SI Project, providing a comprehensive picture of the places were contamination is moving to the surface. During FY 1994 bimonthly sampling was initiated and a greater focus was given to source areas of ${ }^{3} \mathrm{H}$ and ${ }^{90} \mathrm{Sr}$ because these two contaminants pose the greatest risk at White Oak Dam from water ingestion. Sampling transects in Melton Branch identified ${ }^{3} \mathrm{H}$ and ${ }^{90} \mathrm{Sr}$ sources, and two 
seep areas have been identified for Removal Actions to start in late FY 1994. Transect sampling in the WAG 4 tributary showed that ${ }^{3} \mathrm{H}$ and ${ }^{90} \mathrm{Sr}$ sources were not co-located. Flux estimations show that WAG 5 is the source of over half of the ${ }^{3} \mathrm{H}$ flux in the watershed. WAGs 4 and 6 are sources of ${ }^{3} \mathrm{H}$ primarily during the wet seasons. WAGs 1 and 5 are the main sources of ${ }^{90} \mathrm{Sr}$, with WAG 4 being the main contributor during the wet season. Within WAG 1 a significant portion also comes from First Creek, which is probably related to the Corehole 8 plume.

In the Tributary Assessment Task, tributaries were ranked with respect to the contribution of contaminants to the White Oak Creek system. High priority sites were intensively monitored during storms to determine the types and quantities of contaminants that are discharged during high flow conditions. Relationships between concentration and discharge (C-Q) have been developed from monitoring data, and preliminary results show that the partial dilution of contaminants occurs during storms but that flux increases.

Contaminant flux data from the main weirs are compared to reference levels. At MBWEIR, WOCWEIR, and White Oak Dam, excess sulfate, fluoride, and zinc were detected. In addition, at White Oak Dam, (the final release point from the Oak Ridge Reservation) excess chromium, aluminum, iron, manganese, total organic carbon, oil and grease, phosphorus, and total dissolved solids were detected. White Oak Creek results are comparable with those at White Oak Dam, but metals are more like those found in the reference waters. With respect to organic contaminants, none found in Melton Branch exceeded the reporting level at the ambient monitoring stations.

The annual radiological contaminant fluxes from White Oak Dam for 1993 were 1800, $2.1,0.53$, and $0.046 \mathrm{Ci}$ for ${ }^{3} \mathrm{H},{ }^{90} \mathrm{Sr},{ }^{137} \mathrm{Cs}$, and ${ }^{60} \mathrm{Co}$, respectively. The results are similar to those of the previous three years. The distribution of contaminant sources within the watershed corresponds to the detailed patterns from the extensive seep surveys.

The ORNL site conceptual hydrologic model was expanded to include an annual cycle in the flux of contaminants. Results also show that C-Q relationships vary seasonally, with higher concentrations associated with wetter conditions and low concentrations associated with drier conditions. These data were used to estimate annual contaminant discharge, but they mainly serve to show the annual cycle in contaminant flux. Cumulative flux of contaminants over a 6-year period show a distinct annual cycle with the largest fluxes in the late fall-early winter time period when groundwater storage is filled and precipitation is discharged as runoff. This seasonal cycle of contaminant flux is important to the interpretation of monitoring data, to the understanding of contaminant transport, and to design of remedial actions, which must reduce contaminant movement to surface water throughout the entire annual cycle. 


\title{
3. GROUNDWATER
}

\author{
R. H. Ketelle, P. M. Jardine, L. E. Toran, D. S. Hicks, R. S. Loffman, \\ W. E. Sanford, and J. F. Gwo
}

\subsection{INTRODUCTION}

Groundwater investigations at ORNL are performed under two major programmatic areas: the ORNL ER Program and the ORNL Compliance Monitoring Program implemented by the Office of Environmental Compliance and Documentation. Data acquisition by these two programs is coordinated at the site level to facilitate sharing of information and to prevent duplication of effort and expenditures in groundwater monitoring activities.

During FY 1994 groundwater data collection activities at ORNL included ongoing sampling and analysis of wells at WAG perimeters; investigations related to the Remedial Investigation of WAG 5; well sampling, analysis, and water level data collection at WAG 1 under a post-Phase $1 \mathrm{RI}$ monitoring activity; water level monitoring at wells throughout the ORNL site (Fig. 3.1); and hydraulic head measurement at 13 Hydrostatic Head Measurement Stations. During FY 1994 a monitoring plan for the WAG 6 site was developed, and implementation of that monitoring will occur late in FY 1994 and will continue through FY 1995 and beyond.

This section summarizes data interpretation that has been performed on the WAG perimeter water quality analyses with respect to potential risk levels associated with contaminated groundwater at ORNL.

\subsection{AREA GROUNDWATER PROGRAM INTERACTIONS WITH CONTAMINANT SOURCE WAG ACTIVITIES}

The ORNL Area Groundwater Program provides site-wide data collection and interpretation throughout the ORNL complex. The broad perspective provided by the Area Groundwater Program is important to the ER Program and to the Laboratory because it is the basis of integrating data from different sources and different geographic areas to answer key site management questions. Examples of the types of site management activities that have been influenced by the Area Groundwater Program include: establishing priorities for well plugging and abandonment, defining the data collection needs for area-wide groundwater level monitoring, providing site conceptual models for contaminant source WAGs, such as WAG 4, based on a rapid interpretation of existing site data, and providing technical support to CERCLA activities and removal actions for managing contaminated groundwater such as the WAG 5 seeps and the Corehole 8 plume removal actions.

\subsection{WAG PERIMETER WATER QUALITY MONITORING}

Groundwater sampling and analysis for general chemical constituents and contaminant parameters is implemented at 160 high quality wells located at the perimeter of the 


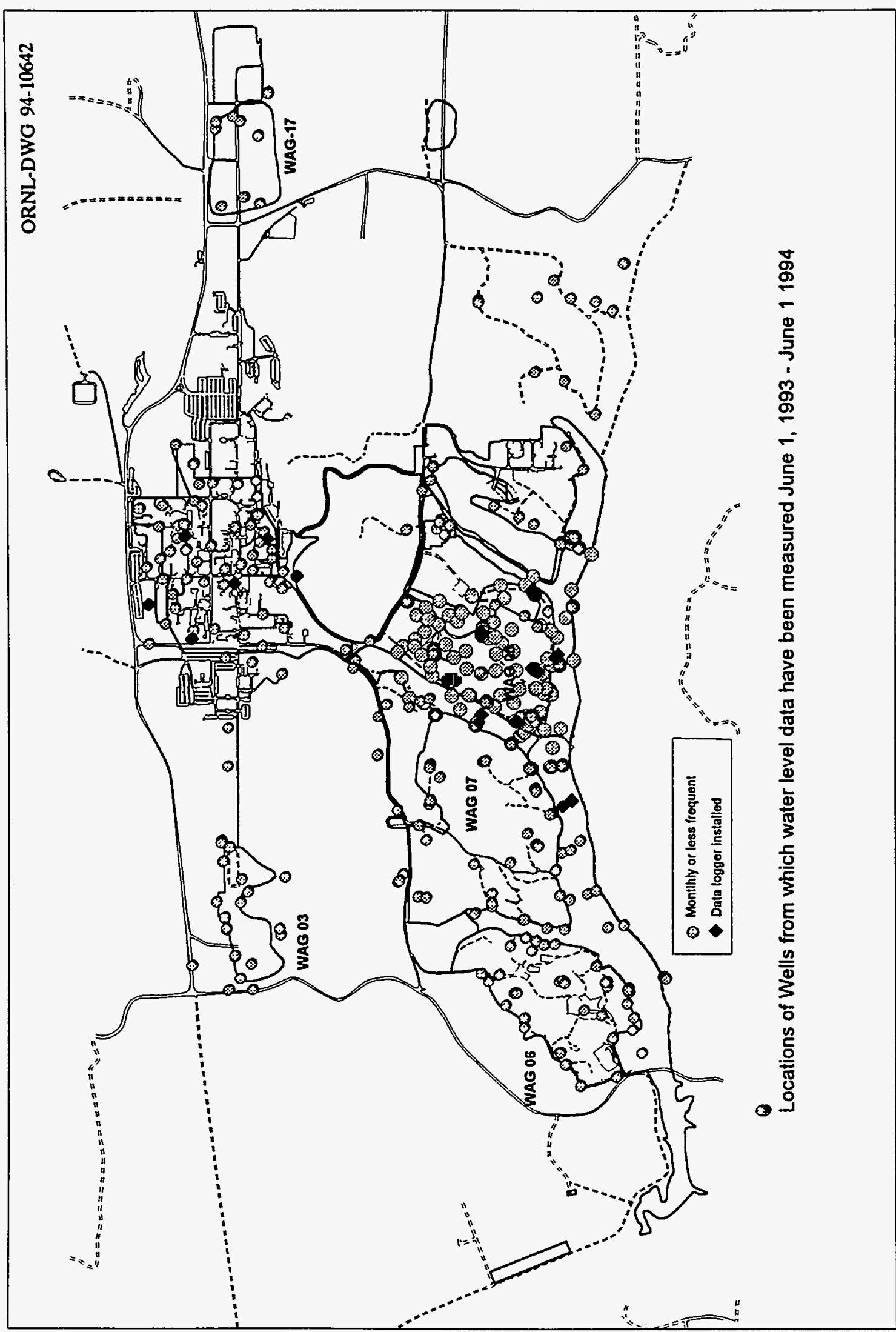

条 
contaminant source WAGs. This monitoring network was constructed to allow measurement of the presence, concentration, and temporal variation of contaminants at the boundary of the individual contaminant source areas throughout the ORNL site. The monitoring network includes sampling of wells located upgradient and downgradient of each WAG and groundwater from each geologic formation at the ORNL site upon which contaminated sites occur. The WAG perimeter well network includes wells constructed at the weathering interface between soil (residuum) and bedrock and deeper wells constructed approximated $10 \mathrm{~m}$ below the bedrock surface.

\subsubsection{Summary of FY 1993 WAG Perimeter Well Data}

The results in this section mention "total radioactive strontium," which is the sum of ${ }^{89} \mathrm{Sr}$ and ${ }^{90} \mathrm{Sr}$. Because ${ }^{90} \mathrm{Sr}$ is the predominant radioisotope, this measure is virtually equivalent to a ${ }^{90} \mathrm{Sr}$ concentration.

WAG 1 Results. In 1993, as in the past, radionuclides have been detected in a number of WAG 1 wells, with gross alpha and gross beta activity and total radioactive strontium above drinking water standards at a few wells. The highest levels of radioactivity continue to be observed in the same five wells: one in the northwest plant area and four wells in the southwest and western plant area. (The upgradient wells are located in the northeast corner of the WAG.)

The well in the northwest plant area continues to show an elevated gross alpha level that is attributable to ${ }^{234} \mathrm{U}$ and ${ }^{238} \mathrm{U}$. The gross beta activity at the five wells of concern is attributable mainly to the total radioactive strontium and its daughters.

Organic compounds were detected in a few wells; however, most of these were also detected in the laboratory blanks or were at levels within five times the analytical detection limit, and none of the concentrations exceeded drinking water standards.

WAG 2 Results. At WAG 2, most of the downgradient wells are to the west and downstream. The upgradient wells are to the east and upstream. WAG 2 receives contamination from many other WAGs, and this seems to be reflected in the analytical results. Major contributors of ${ }^{3} \mathrm{H}$ and total radioactive strontium to WAG 2, in order of contribution, are WAGs 5,8 and $9,4,1,6$, and 7 .

For example, four of the WAG 2 wells that exhibited high levels of ${ }^{3} \mathrm{H}$ are located south of and downgradient of WAGs 5, 6, and 8. All of the WAG 2 wells show evidence of radioactive contamination, including gross alpha, gross beta, and ${ }^{3} \mathrm{H}$. Gross beta activity above primary drinking water standards was detected at the two wells on the west side of WAG 7 and at one well south of WAG 6 . The elevated levels of ${ }^{3} \mathrm{H}$ and total radioactive strontium in the perimeter wells at White Oak Dam are believed to be the result of surface water underflow at the dam, not groundwater contamination.

Tritium concentrations in the wells at the east end of White Oak Lake were inconsistent with the previous two sampling events. Several of the wells had tritium concentrations two and three times previously observed values.

Little volatile organic contamination was detected in the wells. Acetone and carbon disulfide were detected at one of the wells on the west side of WAG 7 at levels higher than 
in the past. However, the concentrations were below 10 times the analytical detection limit, a rule of thumb used to determine organic presence applied to common laboratory contaminants.

Chromium was detected above Tennessee general water quality criteria at a well south of WAG 6. This well has had similar results during the past two sampling events. Nitrate was detected for the second time slightly above drinking water standards at the well on the west side of WAG 7.

WAG 3 Results. Analytical results for 1993 at WAG 3 are similar to those obtained in the previous 2 years. WAG 3 is located on a north-facing slope with its upgradient wells to the south. The long axis of the site runs east to west; consequently, most of the downgradient wells are along the northern border.

Total radioactive strontium is present along the entire northern perimeter of the site. Values exceeding the primary drinking water standard for total radioactive strontium and gross beta activity have consistently been observed at four wells in every sampling event. Apparently, the gross beta signatures are mainly attributable to radioactive strontium. The data for the eastern and northeastern boundaries show evidence of radioactive contamination, including ${ }^{3} \mathrm{H}$ and gross alpha activity. The data for the northwest boundary show the presence of ${ }^{3} \mathrm{H}$.

A few of the wells had volatile organics detected but at levels within five times the analytical detection limit. Trichloroethene has consistently been detected above drinking water standards in every sampling event at one well located in the northeast part of the WAG. The values have always been less than five times the analytical detection limit for the analysis method used.

WAG 4 Results. Sampling at WAG 4 was initiated in December 1993 and completed in January 1994.

WAG 5 Results. The results for 1993 sampling are similar to results from previous sampling events. WAG 5 contributes a significant percentage of the ${ }^{3} \mathrm{H}$ and total radioactive strontium that is discharged from the ORNL site at White Oak Dam via Melton Branch. Tritium contamination in groundwater is particularly prevalent on the southern and western boundaries of the WAG, with values as high as $270,000,000 \mathrm{pCi} / \mathrm{L}$.

Strontium radioisotopes appear to be the major beta emitter (other than ${ }^{3} \mathrm{H}$ ) found in WAG 5 groundwater. It is found mainly on the southern perimeter. Alpha activity above drinking water standards was observed in one well on the northwestern boundary of the WAG and one well on the southern boundary.

Volatile organic compounds were detected on the southern and western boundaries, including 1,2-dichloroethene, vinyl chloride, trichloroethene, and benzene. Several wells have consistently exceeded drinking water standards for these contaminants. No upgradient wells exceeded regulatory standards for radionuclides or volatile organics.

WAG 6 Results. Results obtained during 1993 were comparable to past results. Volatile organic compound contamination is apparently isolated in the area around a pair of wells in the northeast corner of the perimeter. During 1993, 1,2-dichlorethane, carbon tetrachloride, 
and trichloroethene were detected above drinking water standards at one of these wells in almost every sampling event. This well is subject to the quarterly RCRA assessment monitoring.

Elevated levels of ${ }^{3} \mathrm{H}$ are found along the eastern perimeter, with the highest levels found in six of the eight RCRA quarterly assessment wells.

WAG 7 Results. Results obtained during 1993 were comparable to past results. Tritium was detected in more than half of the wells but was highest along the western perimeter next to SWSA 6. Compared with previous years, ${ }^{3} \mathrm{H}$ appears to be decreasing at the wells on the western perimeter and increasing on the southern perimeter.

Gross alpha activity was detected at one well in excess of primary drinking water standards. This activity can be attributed to ${ }^{241} \mathrm{Am},{ }^{238} \mathrm{Pu},{ }^{239} \mathrm{Pu},{ }^{228} \mathrm{Th},{ }^{230} \mathrm{Th},{ }^{234} \mathrm{U},{ }^{235} \mathrm{U}$, and ${ }^{238} \mathrm{U}$. Of these, the ${ }^{238} \mathrm{Pu}$ and ${ }^{234} \mathrm{U}$ exceeded $4 \%$ of the recommended DOE derived concentration guidelines.

Gross beta activity was detected at levels in excess of primary drinking water standards at five wells, and tritium also above drinking water standards at four of these wells.

Two wells have consistently had nitrate detected at levels that exceed primary drinking water standards. Minimal volatile organic contamination has been detected in the WAG 7 wells.

WAGs 8 and 9 Results. The two upgradient wells are located north of the WAGs. Two of the downgradient wells are located northwest of the WAGs, two are located south of WAG 8, and the remaining five are in WAG 8 west of WAG 9 and in WAG 9. The analytical results for 1993 are comparable to results from the previous 2 years.

All of the perimeter wells show evidence of radioactive contamination. The data indicates that the gross beta activity is attributable to total radioactive strontium. The two wells on the northwest perimeter exceeded drinking water standards: one well with respect to ${ }^{3} \mathrm{H}$ contamination and the other with respect to gross beta activity and total radioactive strontium contamination. Total radioactive strontium and gross beta activity levels exceeded the drinking water standards at the two WAG 9 wells.

Although volatile organics were detected at downgradient wells, the values were within five times the analytical detection limit. One well has consistently shown trichloroethene above drinking water standards. None of the data for the upgradient wells show evidence of volatile organic contamination.

Exit Pathways Monitoring Results. DOE regulations require groundwater monitoring at exit pathways from facilities known to or suspected of discharging contaminants. At ORNL, the exit pathways are defined by topography, because groundwater flow generally reflects surface water drainage. Exit pathways for Bethel Valley correspond to the Racoon Creek drainage system to the west and Bearden Creek to the east. For Melton Valley, the exit pathways are White Oak Creek at White Oak Dam to the west and Bearden Creek to the east. 
No wells in the eastern and western Bethel Valley exit pathways have ever had either volatile organic or radiological constituents detected above any drinking water standards. The east Bethel Valley surface water location did not have volatile organic or radiological constituents detected above any drinking water standards. In the western Bethel Valley exit pathway, gross beta activity and total radioactive strontium were detected above drinking water standards at the Racoon Creek surface water location. One of the three wells in the western Bethel Valley exit pathway has always been dry when sampled; a second well was also dry at the time of the 1993 sampling.

In the western Melton Valley exit pathway, White Oak Creek at White Oak Dam had gross beta activity and total radioactive strontium concentration detected above drinking water standards and ${ }^{137} \mathrm{Cs}$ above DOE-derived concentration guidelines. One of the wells also had gross beta activity, total radioactive $\mathrm{Sr}$, and ${ }^{3} \mathrm{H}$ concentration detected above drinking water standards; a second well had ${ }^{3} \mathrm{H}$ concentrations detected above drinking water standards. In both cases, this has consistently occurred for the past 3 years. No volatile organic contamination was detected above drinking water standards in either the wells or the surface water location.

WAG 11 Results. WAG 11 is located outside the main ORNL site (see Fig. 1.1) The WAG has gently rolling terrain and the upgradient wells are located north, east, and south of the WAG. In both sampling events for this WAG, gross alpha and gross beta activity contamination was detected at low levels along the entire perimeter of the site, including the upgradient wells. Tritium has been detected in some of the wells although not during both sampling events. No radiological constituents were detected in 1993 above drinking water standards. During both sampling events, trichloroethene was detected above drinking water standards at two wells. No other volatile organics were detected in those wells, and little volatile organic contamination was detected at the other wells.

In the White Wing Scrapyard exit pathway, one well, and the duplicate sample taken at the same time, had trichloroethene detected above drinking water standards, but less than five times the analytical detection limit for the analysis method used to perform the organic analysis. The Bear Creek surface water location had gross alpha activity detected above drinking water standards.

WAG 17 Results. WAG 17 is located to the east of the main ORNL plant area. The WAG includes support and transportation facilities. It is situated on a northwest-facing slope, with its upgradient wells on the eastern border and downgradient wells on the western border. While none of the wells had radiological levels above any drinking water standards, the data for the eastern and western boundaries show evidence of radioactive contamination, including gross beta activity and ${ }^{3} \mathrm{H}$. In the past gross alpha activity has exceeded the drinking water standard at two wells; however, this did not occur in 1993.

The data for the southeastern and southwestern boundaries show evidence of volatile organic contamination. The contamination has consistently been located primarily in one well. The pollutants include trichloroethene, vinyl chloride, benzene, 1,2-dichloroethene, 1,1-dichloroethene, and tetrachloroethene. 


\subsubsection{Potential Risk Associated with ORNL Groundwater}

Data have been obtained from the WAG perimeter well network over a period of several years. During FY 1994 the cumulative data record from all the wells has been interpreted in terms of potential risk to groundwater users. The scenario for calculation of the potential risk associated with consumption of groundwater from the ORNL monitoring wells used the oral cancer slope factor for the contaminant, the mean concentration for the contaminant at each well, and the default U.S. Environmental Protection Agency residential drinking water assumptions for the drinking water pathway [ $2 \mathrm{~L} / \mathrm{d}$ consumption for $350 \mathrm{~d} /$ year for 30 years (EPA 1989)].

Table 3.1 lists the chemical carcinogens detected at least once in the ORNL WAG perimeter monitoring well network and identifies wells, WAGs, and ranges of detected contaminant concentrations. Table 3.2 lists risk associated with each well organized by the WAG which the well monitors. Table 3.2 shows that individual wells at WAGs $1,2,6,7$, and 17 have risks greater than $1 \times 10^{-3}$ and that multiple wells at WAGs 5 and 4 have risks in this risk range. WAGs 1 and 6 have numerous perimeter monitoring wells that fall into the $1 \times 10^{-4}$ order of risk. All but one WAG perimeter monitoring well have greater than $1 \times 10^{-6}$ risk based on the average detected contaminant levels.

Contaminants which contribute the potential total carcinogenic risk in groundwater at ORNL can be categorized as belonging to one of three families of contaminants: radiological contaminants, metals, or organic compounds. Radiological contaminants, particularly total radiological strontium and tritium, dominate the groundwater risk calculations at ORNL. Organic compounds (predominantly vinyl chloride, 1,1-dichloroethene, and trichloroethane) contribute significantly to risk at some wells. Beryllium is detected often in the data set but as an individual analyte typically occurs at risk levels of $5 \times 10^{-5}$ or less.

The spatial distribution of risk generating contaminants at ORNL is shown in Fig. 3.2. This figure shows proportionally scaled symbols which depict the relative risk associated with groundwater contaminants at each well and also shows the percentage of radiological, metal, and organic compound contribution at each well. Figure 3.2 shows that the highest levels of risk associated with groundwater contaminants are along the downgradient perimeters of WAGs 4 and 5.

\subsubsection{Temporal Contaminant Concentration Variation}

The preceding discussions have been based on the risk calculation derived from average contaminant concentrations in groundwater from the WAG perimeter wells at the ORNL site. The wells have all been sampled at least 3 times except at WAG 11 where only two sampling and analysis rounds are complete. The risk calculations have been completed for all available data from the wells and a series of plots has been generated which shows the variation of total risk and the proportion of total risk produced by each individual contaminant through the monitoring history of each well. These plots include data from all contaminants which account for at least $90 \%$ of the total risk at each well.

The time-history plots of total risk and contaminant specific risk in groundwater show that at many wells the contaminant concentrations are stable for practical purposes and that some wells show increases or decreases in contaminant concentrations. No general statement accurately describes the changes of potential risk or contaminant concentration at ORNL. 
Table 3.1. Chemical carcinogens detected at least once in Oak Ridge National Laboratory waste area grouping perimeter monitoring well network

\begin{tabular}{|c|c|c|c|c|}
\hline Chemical of concern & $\begin{array}{l}\text { Number } \\
\text { of wells }\end{array}$ & Well & WAG & $\begin{array}{c}\text { Range of } \\
\text { concentrations } \\
(\mathrm{mg} / \mathrm{L} ; \mathrm{pCi} / \mathrm{L})\end{array}$ \\
\hline 1,1-Dichloroethene & 4 & $954,958,1190,1201$ & $2,4,17$ & $0.017-0.044$ \\
\hline 1,2,3-Trichloropropane & 2 & 818,819 & 1 & 0.005 \\
\hline 1,2-Dibromo-3-chloropropane & 2 & 818,819 & 1 & 0.01 \\
\hline 1,2-Dibromoethane & 2 & 818,819 & 1 & 0.005 \\
\hline 1,4-Dioxane & 2 & 818,819 & 1 & 5.0 \\
\hline 2-Propenenitrile & 2 & 818,819 & 1 & 0.01 \\
\hline 3,3'-Dimethyl-benzidine & 1 & 814 & 1 & 0.085 \\
\hline Aroclor-1254 & 1 & 854 & 6 & 0.001 \\
\hline Beryllium & 58 & $\begin{array}{c}745,806,807,808,809, \\
810,811,812,813,814, \\
816,818,824,827,828, \\
829,830,831,832,833, \\
835,836,837,838,839, \\
840,841,842,843,844, \\
845,846,847,848,849, \\
850,851,852,853,854, \\
855,856,857,858,859, \\
860,986,992,1071, \\
1074,1076,1079,1084, \\
1145,1194,1195,1245, \\
1248\end{array}$ & $\begin{array}{l}1,2,3 \\
6,7,11\end{array}$ & $0.001-0.025$ \\
\hline Bis(2-ethylhexyl)phthalate & 1 & 977 & 1 & 3.1 \\
\hline Carbon tetrachloride & 1 & 842 & 6 & 0.0614 \\
\hline${ }^{60} \mathrm{Co}$ & 3 & $1078,1243,1244$ & $2,6,7$ & $432-915$ \\
\hline N-Nitroso-di-n-propylamine & 1 & 809 & 1 & 0.008 \\
\hline${ }^{228} \mathrm{Ra}$ & 1 & 973 & 5 & 77.4 \\
\hline${ }^{90} \mathrm{Sr}$ & 13 & $\begin{array}{c}806,812,956,969,973 \\
975,992,993,994, \\
1087,1096,1097,1191\end{array}$ & $\begin{array}{r}1,2,3 \\
4,5,8\end{array}$ & $140-7,900$ \\
\hline${ }^{99} \mathrm{Tc}$ & 1 & 1078 & 7 & 11,000 \\
\hline Tritium & 31 & $\begin{array}{c}841,842,843,847,848, \\
849,854,954,955,956, \\
957,958,968,969,970, \\
971,972,973,974,975, \\
976,977,978,981 \\
1076,1079,1084,1152, \\
1156,1191,1243\end{array}$ & $\begin{array}{c}2,4,5 \\
6,7\end{array}$ & $\begin{array}{c}93,800- \\
290,000,000\end{array}$ \\
\hline${ }^{234} \mathrm{U}$ & 1 & 812 & 1 & 346 \\
\hline Vinyl chloride & 16 & $\begin{array}{c}818,819,825,830,849, \\
853,854,954,955,958, \\
969,973,975,978,981 \\
1201\end{array}$ & $\begin{array}{c}1,4,5 \\
6,17\end{array}$ & $0.005-5.5$ \\
\hline
\end{tabular}


Table 3.2. Total carcinogenic risk associated with each well organized by the waste area grouping that the well monitors

\begin{tabular}{|c|c|c|c|c|c|c|c|c|c|c|c|c|c|c|c|c|c|c|c|c|}
\hline Risk & & $\overline{A G ~} 1$ & & $\widehat{A G ~} 2$ & & $\overline{A G 3}$ & & $\overline{A G 4}$ & & AGS & & AG 6 & & $\overline{A G 7}$ & & $\overline{A G} 8$ & $\overline{W A}$ & $\overline{A G ~ 11}$ & & $\overline{\mathrm{AG} 17}$ \\
\hline & Well & Risk & Well & Risk & Well & Risk & well & Risk & Well & Risk & Well & Risk & well & Risk & Well & Risk & Well & Risk & Well & Risk \\
\hline \begin{tabular}{|l|}
$\times 10-1$ \\
\end{tabular} & & & & & & & & & \begin{tabular}{|l|}
973 \\
978 \\
\end{tabular} & $\begin{array}{l}2.8 E-01 \\
2.0 E-01 \\
\end{array}$ & & & & & & & & & & \\
\hline $\mid 7 \times 10-2$ & \begin{tabular}{|l|}
814 \\
818 \\
819 \\
\end{tabular} & $\begin{array}{l}1.6 E-02 \\
1.2 E-02 \\
1.1 E-02\end{array}$ & & & & & \begin{tabular}{|l|}
958 \\
854
\end{tabular} & $\begin{array}{l}6.4 E-02 \\
1.7 E-02\end{array}$ & $\begin{array}{l}874 \\
980 \\
975 \\
\end{array}$ & $\begin{array}{l}.1 E-02 \\
2.2 E-02 \\
1.1 E-02\end{array}$ & & & & & & & & & & \\
\hline $1 \times 10-3$ & $\begin{array}{l}812 \\
809 \\
825\end{array}$ & $\begin{array}{l}6.7 E-03 \\
2.4 E-03 \\
1.0 E-03\end{array}$ & & & & & 957 & $7.9 E-03$ & $\begin{array}{l}877 \\
870 \\
981 \\
971 \\
870\end{array}$ & $\begin{array}{l}8.7 E-03 \\
0.9 E-03 \\
1.7 E-03 \\
1.4 E-03 \\
1.3 E-03\end{array}$ & \begin{tabular}{|l}
843 \\
848 \\
837 \\
1243 \\
812 \\
831 \\
840 \\
841 \\
858 \\
\end{tabular} & $\begin{array}{l}3.1 E-03 \\
2.6 E-03 \\
2.6 E-03 \\
2.3 E-03 \\
1.7 E-03 \\
1.5 E-03 \\
1.4 E-03 \\
1.3 E-03 \\
1.2 E-03\end{array}$ & 1078 & $1.5 E-03$ & & & & & 1201 & $6.6 E-03$ \\
\hline $1 \times 10-4$ & \begin{tabular}{|l|}
808 \\
807 \\
830 \\
808 \\
813 \\
829 \\
824 \\
828 \\
827 \\
811 \\
810 \\
816 \\
815 \\
826 \\
946 \\
947 \\
\end{tabular} & $\begin{array}{l}6.6 E-04 \\
5.5 E-04 \\
5.1 E-04 \\
4.7 E-04 \\
4.5 E-04 \\
4.4 E-04 \\
4.0 E-04 \\
3.6 E-04 \\
3.4 E-04 \\
3.2 E-04 \\
3.1 E-04 \\
2.1 E-04 \\
1.1 E-04 \\
1.1 E-04 \\
1.1 E-04 \\
1.0 E-04\end{array}$ & \begin{tabular}{|l|}
1191 \\
1180 \\
1152 \\
1150 \\
1184 \\
1185
\end{tabular} & $\begin{array}{l}8.8 E-04 \\
7.2 E-04 \\
3.6 E-04 \\
3.2 E-04 \\
1.5 E-04 \\
1.2 E-04\end{array}$ & \begin{tabular}{|c|}
994 \\
992 \\
993 \\
1248 \\
886
\end{tabular} & $\begin{array}{l}5.5 E-04 \\
2.4 E-04 \\
1.0 E-04 \\
1.6 E-04 \\
1.3 E-04\end{array}$ & $\begin{array}{l}955 \\
850 \\
980\end{array}$ & $\begin{array}{l}8.4 E-04 \\
7.4 E-04 \\
1.1 E-04\end{array}$ & $\begin{array}{l}872 \\
868 \\
884 \\
867\end{array}$ & $\begin{array}{l}5.3 E-04 \\
3.3 E-04 \\
1.2 E-04 \\
1.0 E-04\end{array}$ & \begin{tabular}{|l|}
856 \\
857 \\
855 \\
847 \\
823 \\
745 \\
844 \\
839 \\
638 \\
1244 \\
832 \\
836 \\
859 \\
835 \\
860 \\
1245 \\
\end{tabular} & $\begin{array}{l}0.8 E-04 \\
8.6 E-04 \\
7.8 E-04 \\
4.7 E-04 \\
4.4 E-04 \\
4.2 E-04 \\
4.2 E-04 \\
3.7 E-04 \\
3.4 E-04 \\
2.8 E-04 \\
2.8 E-04 \\
2.2 E-04 \\
2.2 E-04 \\
1.8 E-04 \\
1.6 E-04 \\
1.5 E-04\end{array}$ & \begin{tabular}{|l|}
1079 \\
1078 \\
1084 \\
1071 \\
1074 \\
\end{tabular} & $\begin{array}{l}.3 \mathrm{E}-04 \\
6.2 \mathrm{E}-04 \\
3.1 \mathrm{E}-04 \\
1.2 \mathrm{E}-04 \\
1.2 \mathrm{E}-04\end{array}$ & $\begin{array}{l}1097 \\
1098 \\
1087\end{array}$ & $\begin{array}{l}\text { B.0E-04 } \\
7.0 E-04 \\
6.1 E-04\end{array}$ & 1145 & $5.7 E-04$ & & \\
\hline $1 \times 10-5$ & $\begin{array}{l}820 \\
822 \\
823 \\
821\end{array}$ & $\begin{array}{l}8.3 E-05 \\
6.8 E-05 \\
3.0 E-05 \\
2.7 E-05\end{array}$ & \begin{tabular}{|l|}
1151 \\
1182 \\
1180 \\
1154 \\
1183 \\
1153 \\
1185 \\
1188 \\
1155 \\
1150 \\
1188 \\
1187 \\
\end{tabular} & $\begin{array}{l}1.0 E-05 \\
3.7 E-05 \\
3.4 E-05 \\
3.0 E-05 \\
2.7 E-05 \\
2.6 E-05 \\
1.8 E-05 \\
1.7 E-05 \\
1.6 E-05 \\
1.3 E-05 \\
1.3 E-05 \\
1.0 E-05\end{array}$ & \begin{tabular}{|l|}
997 \\
987 \\
985 \\
080 \\
981 \\
988 \\
995
\end{tabular} & $\begin{array}{l}.8 E-05 \\
2.6 E-05 \\
2.5 E-05 \\
2.0 E-05 \\
1.6 E-05 \\
1.5 E-05 \\
1.1 E-05\end{array}$ & \begin{tabular}{|l|}
049 \\
852 \\
061 \\
959 \\
962 \\
851 \\
850
\end{tabular} & $\begin{array}{l}5.1 E-05 \\
4.3 E-05 \\
3.4 E-05 \\
2.7 E-05 \\
2.1 E .05 \\
1.5 E-05 \\
1.1 E .05\end{array}$ & \begin{tabular}{|l|}
282 \\
283 \\
979 \\
885 \\
803 \\
804 \\
980 \\
880
\end{tabular} & $\begin{array}{l}9.3 E-05 \\
8.5 E-05 \\
7.1 E-05 \\
4.8 E-05 \\
1.3 E-05 \\
2.8 E-05 \\
2.2 E-05 \\
1.7 E-05\end{array}$ & & & $\begin{array}{l}1077 \\
1073 \\
1075 \\
1072 \\
1081 \\
1082 \\
1083 \\
1085 \\
1088 \\
1080\end{array}$ & $\begin{array}{l}.8 E-05 \\
7.1 E-05 \\
6.1 E-05 \\
5.1 E-05 \\
3.5 E-05 \\
3.5 E-05 \\
2.8 E-05 \\
2.1 E-05 \\
1.9 E-05 \\
1.6 E-05\end{array}$ & $\begin{array}{l}1088 \\
1089 \\
1090 \\
1091 \\
1095 \\
1093 \\
1092 \\
1094 \\
\end{array}$ & $\begin{array}{l}8.8 E-05 \\
5.9 E-05 \\
3.8 E-05 \\
3.8 E-05 \\
3.3 E-05 \\
2.5 E-05 \\
2.0 E-05 \\
1.3 E-05\end{array}$ & \begin{tabular}{|l|}
1246 \\
1149 \\
1148 \\
1143 \\
1144 \\
\end{tabular} & $\begin{array}{l}.6 E-05 \\
3.3 E-05 \\
3.0 E-05 \\
2.4 E-05 \\
1.8 E-05\end{array}$ & \begin{tabular}{|l|}
1198 \\
1180 \\
1189 \\
1203 \\
1200 \\
1202 \\
1197
\end{tabular} & $\begin{array}{l}.8 E-05 \\
4.1 E-05 \\
2.4 E-05 \\
2.0 E-05 \\
1.8 E-05 \\
1.7 E-05 \\
1.6 E-05\end{array}$ \\
\hline $9 \times 10-8$ & & & & & $\begin{array}{l}886 \\
988\end{array}$ & $\begin{array}{l}7.5 E-08 \\
5.5 E-08\end{array}$ & \begin{tabular}{|l|}
853 \\
848
\end{tabular} & $\begin{array}{l}8.7 E-06 \\
5.7 E-06\end{array}$ & & & & & & & & & \begin{tabular}{|l|}
1140 \\
1139 \\
1147 \\
1148 \\
\end{tabular} & $\begin{array}{l}8.8 E-06 \\
8.5 E-08 \\
8.3 E-08 \\
6.1 E-08 \\
\end{array}$ & & \\
\hline
\end{tabular}




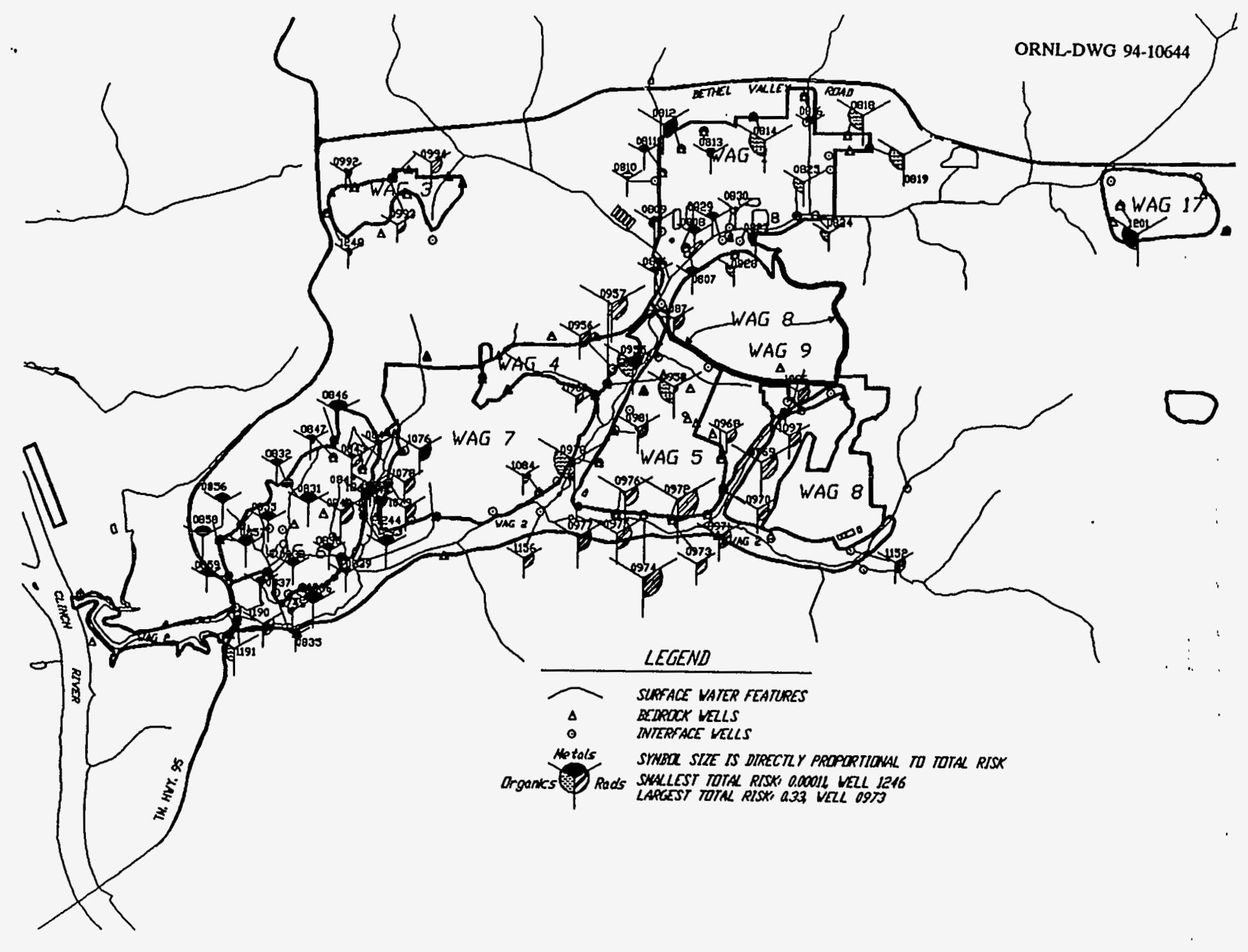

Fig. 3.2. Spatial distribution of risk generating contaminants at Oak Ridge National Laboratory. 
Several examples of these plots are shown in Appendix B.

\subsection{GROUNDWATER MODELING AND EXPERIMENTATION}

Groundwater modeling activities support a variety of ER initiatives. The major benefits of computer modeling are the increased understanding of the environmental systems that must be remediated, leading to better decisions regarding remedial alternatives and better engineering designs of remediation systems. Computer simulations of subsurface contaminant transport combined with exposure scenarios and risk calculations provide a rational basis for evaluating and prioritizing remedial actions.

This subsection consists of brief descriptions of four computer modeling activities followed by a summary of laboratory and field experiments designed to advance our modeling capabilities. To address the groundwater-related issues of current relevance to the ER Program the four modeling activities are (1) estimation of groundwater contaminant fluxes from WAG 6; (2) evaluation of impermeable caps, one option for isolation of buried wastes; (3) modeling of regional groundwater flows in Melton Valley and any flows that may be leaving Melton Branch and moving to potential off-site receptors; and (4) application of a new fracture-flow groundwater model developed at the University of Waterloo. The laboratory and field work summarized in the remainder of this section is designed to advance our ability to model the complex fracture-dominated groundwater system at ORNL.

\subsubsection{WAG 6 Groundwater Flux Calculations}

Groundwater modeling provided important the information needed to support an ER decision to defer significant remedial actions from WAG 6. The option to defer remedial actions was based on calculations showing contaminant releases from WAG 6 are a very small portion of contaminant discharges leaving the ORNL site. To improve our estimates of offWAG contaminant discharges at WAG 6 it was necessary to model the groundwater component in the shallow and intermediate intervals and to use this information in risk calculations.

The approach to this problem was to calculate the subsurface water flux and to use mean concentrations of contaminants measured in wells at the WAG boundary to generate the contaminant discharge. Groundwater fluxes for risk assessment were calculated along five separate sections (DOE 1993) representing the assumed drainage areas of WAG 6 not captured by surface water monitoring. Fluxes were calculated by three methods: (1) estimates of flux through recharge area for the different catchments (DOE 1993a), (2) a small area model of WAG 6, and (3) a regional Melton Valley model encompassing WAG 6 (West and Toran 1994).

The simulated fluxes agree quite well in light of the differences in model construction and uncertainty of input parameters. Risk assessment modeling, to be conservative, should probably use the highest value calculated.

\subsubsection{Effect of Caps on Stormflow}

At WAG 6 part of the buried wastes are covered with caps consisting of impermeable plastic membranes anchored to the surface. The caps were constructed in 1988-89 as an 
interim corrective action required to meet RCRA regulations. The performance of the caps affects future decisions regarding the replacement of the caps which tend to deteriorate. Computer modeling improves the understanding of how the shallow stormflow zone affects the hydrologic isolation provided by the caps.

Perched water is believed to develop on many waste area hillslopes during storm events, but the water flux in this shallow stormflow zone is transient and difficult to monitor. Modeling can help assess whether caps will effectively cut off stormflow from waste trenches. A hypothetical hillslope based on data from WAG 6 was modeled as a cross section, and a sensitivity analysis was performed to evaluate the key parameters in development of stormflow. The sensitivity analysis, using Latin hypercube design and multiple linear regression for analysis of results, indicated that hydraulic conductivity was the key factor in size and flux of subsurface stormflow. Rainfall intensity was less important. For all cases, stormflow contributed $96.5 \%$ or more of the total discharge at the base of the slope. Vector diagrams of the flow under the caps indicated that stormflow would occur beneath caps located below the top of the hillslope (Fig. 3.3). Furthermore, low permeability lenses in the soil have a strong influence on flow patterns and can further enhance underflow beneath caps. This modeling result combined with other studies indicate that the caps are not very effective in hydrologically isolating the waste and that costly replacement actions for the caps when they deteriorate may not be cost effective.

\subsubsection{Regional Groundwater Flow Modeling}

The regional groundwater flow modeling being conducted on the ORNL super computer (and used for flux calculations described in Sect. 3.4.1) has been expanded to include caps. The model now includes WAG 5 and WAG 10. The model can be used to evaluate potential groundwater pathways of both shallow and deep waste disposal. Calibration of the model during FY 1994 focuses on improving estimates of recharge and hydraulic conductivity by incorporating transient modeling of seasonal water level fluctuations. Data sets have been created for this calibration effort and estimated run-times on the supercomputer are $24 \mathrm{~h}$ or more.

\subsubsection{Fracture Flow Modeling of Transport on the Reservation}

Testing of a new 3-dimensional fracture flow modeling code is underway for a real and a hypothetical plume in fractured systems on the Oak Ridge Reservation. The code is still under development at the University of Waterloo, where they are adapting the model grid to allow for fractures along tilted bedding such as occurs on the Oak Ridge Reservation. The model will then be used to examine potential fracture flow transport near Corehole 8 in WAG 1 and to contrast hypothetical transport in two waste settings: a hillslope waste area where gradients can be steep, and a valley waste area where more lateral dispersion of plumes has been observed. These studies will help assess how fractures influence the shape of plumes developed and try to quantify the size of secondary sources that develop around fractures. The Waterloo model was used extensively in the laboratory studies reported in the next section. 


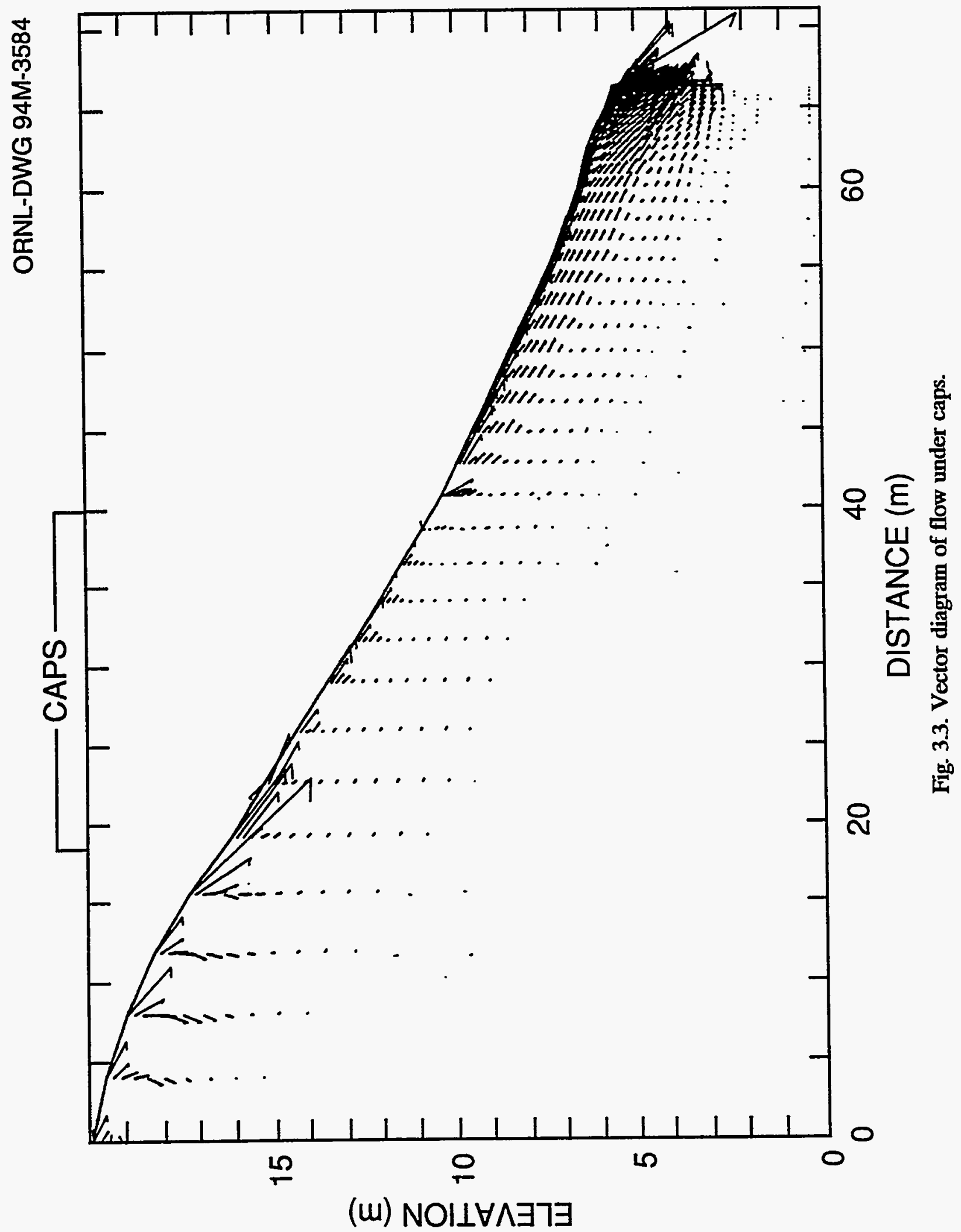




\subsubsection{Hydrologic Pathways Investigation}

This ongoing task has the goals of (1) advancing the conceptual understanding of how contaminants are transported by groundwater in the complex geology found at ORNL and (2) validating mathematical models that depict the true groundwater transport mechanisms to produce predictive tools for the design and assessment of remedial actions. The main benefit will be better informed decisions as to the effects of proposed remedial actions, such as capping waste trenches for hydrologic isolation. The work summarized in this section extends the initial investigations reported in the Sect. 3.5 "Hydrologic Pathways and Secondary Sources" in ERMA (1992), which introduced the concept of primary and secondary contaminant sources. Past progress on this task was reported by Wickliff et al. 1991, and Hicks et al. 1992.

If the primary contaminant source (contamination remaining in burial trenches) is small relative to the secondary contaminant source (contamination leached from the trenches and now stored in the porous matrix of the soil and rock), then remedial actions to remove or isolate the waste in the trenches may not achieve the desired effect. The secondary source may sustain a prolonged discharge of contaminants to streams, and there may be no measurable benefit of the remediation for years, even decades. Consequently, a quantitative understanding of secondary sources is imperative for the selection of effective remedial actions and for the interpretation of monitoring results after a remediation is completed.

Secondary sources are partly characterized by the advective transport rate, which is the rate of movement of solutes through preferential flow paths, such a fractures, joints, and dissolution cavities. These macropores are known to rapidly transport contaminants over significant distances. Secondary sources are also characterized by the diffusive transport rates that move contaminants into and out of the porous soil/rock matrix that surrounds each macropore. In concept, this matrix diffusion is known to buffer contamination leached from the primary sources and to cause the prolonged discharge of contaminants after primary sources have been cleaned up. Mathematical models of groundwater flow that include matrix diffusion are considered to be innovative, and there are no standard, established methods to identify parameter values for these models.

The specific objectives of this task are to use laboratory and field investigations to (1) quantify the advective and diffusive mass transfer of ${ }^{3} \mathrm{H}$ and ${ }^{90} \mathrm{Sr}$ within the secondary source at WAG 5, (2) enhance our predictive capability of ${ }^{3} \mathrm{H}$ and ${ }^{90} \mathrm{Sr}$ mobility from the ORNL burial grounds, and (3) define the importance of primary and secondary sources of ${ }^{3} \mathrm{H}$ and ${ }^{90} \mathrm{Sr}$ relative to the contamination discharged to the streams along the perimeter of WAG 5 . To achieve these objectives, experimental and theoretical investigations of the transport of nonreactive tracers in subsurface systems were conducted to define the migration patterns of ${ }^{3} \mathrm{H}$ and also ${ }^{90} \mathrm{Sr}$. The behavior of ${ }^{90} \mathrm{Sr}$ differs from that of ${ }^{3} \mathrm{H}$ because movement of ${ }^{90} \mathrm{Sr}$ is retarded by exchange reactions that take place at the surface of the soil or rock particles.

\subsubsection{Laboratory studies}

In the laboratory, the transport of tracers in undisturbed subsurface columns of weathered shale were studied. The shale columns, acquired from an uncontaminated site near WAG 5, were carefully collected to preserve the flow paths along bedding planes. Four techniques were employed to quantify contaminant mass transfer processes in these cores: (1) tracer experiments at a variety of realistic, steady groundwater flow rates, (2) tracer 
experiments using an innovative nonsteady, flow-interruption technique, (3) experiments using multiple tracers with different diffusion coefficients, and (4) experiments with large-particle tracers that could not diffuse into the matrix.

Results showed that contaminants were preferentially transported through the weathered shale via macropores. Contaminant movement into the surrounding matrix was significant and was controlled by both advective and diffusive solute mass transfer processes (O'Brien and Jardine 1994a; 1994b). The rate of mass transfer into the matrix was shown to be more rapid with increased pore water velocities (O'Brien and Jardine $1994 \mathrm{c}$ ). The typical breakthrough plot shown in Fig. 3.4 has a fundamentally different shape than the conventional curve derived from transport through a simple porous medium, such as a column of sand. At field scales the corresponding breakthrough curve is expected to have a very long tail, indicating elevated concentrations of contaminant over many years.

For the first time, it was demonstrated that the flow-interruption technique can be used to quantify the rate of non-reactive contaminant diffusion in heterogeneous media (Reedy et al. 1994a,b; O'Brien and Jardine 1994 a,b,c). Initial results suggest that a logarithmic decrease in the rate of contaminant diffusion into the matrix occurred with time (Reedy et al. 1994 a,b).

Using bromide $\left(\mathrm{Br}^{-}\right)$and pentafluorobenzoic acid (PFBA) as tracers, which have very different atomic/molecular weights and therefore different diffusion coefficients, distinctly different breakthrough patterns for the two solutes were observed. The difference in breakthrough concentrations conclusively showed that matrix diffusion was the predominant mechanism that retards the solute movement and not chemical interactions between the solute and the matrix. These experiments further indicate that diffusion occurs throughout all stages of contaminant breakthrough and that the rate of diffusion into the matrix decreased with time.

Experiments have been initiated, in collaboration with the University of Tennessee, in our undisturbed subsurface columns using two strains of bacteriophage and colloidal-size glass spheres. These particles are too large to diffuse into the surrounding matrix, thus they can be used to directly quantify the advective transport rate in heterogeneous media without the complication of diffusion. Initial results suggest that the bacteriophage are indeed transported rapidly through the media via advective flow.

\subsubsection{Field studies}

Field studies involve investigating the transport of multiple nonreactive tracers at Source Area $\mathrm{A}$ in WAG 5, as shown in the map in Fig 2.7. Injection of $\mathrm{Br}^{-}$and the dissolved gases $\mathrm{He}$ and $\mathrm{Ne}$ as tracers (Sanford et al. 1994) will be used to establish the extent of contaminant diffusion into the soil/rock matrix associated with groundwater transport under field conditions. The diffusion coefficients for these tracers are different due to differing atomic weights, thus the use of multiple tracers allows the effects of diffusion to be uniquely identified. Monitoring of the spatial and temporal distributions of the tracers will be done downgradient from the injection source, using multilevel piezometric sampling arrangements and multilevel drive point wells located along the contaminant flow path. The injection will be initiated in September 1994 and monitoring will continue into FY 1995. 


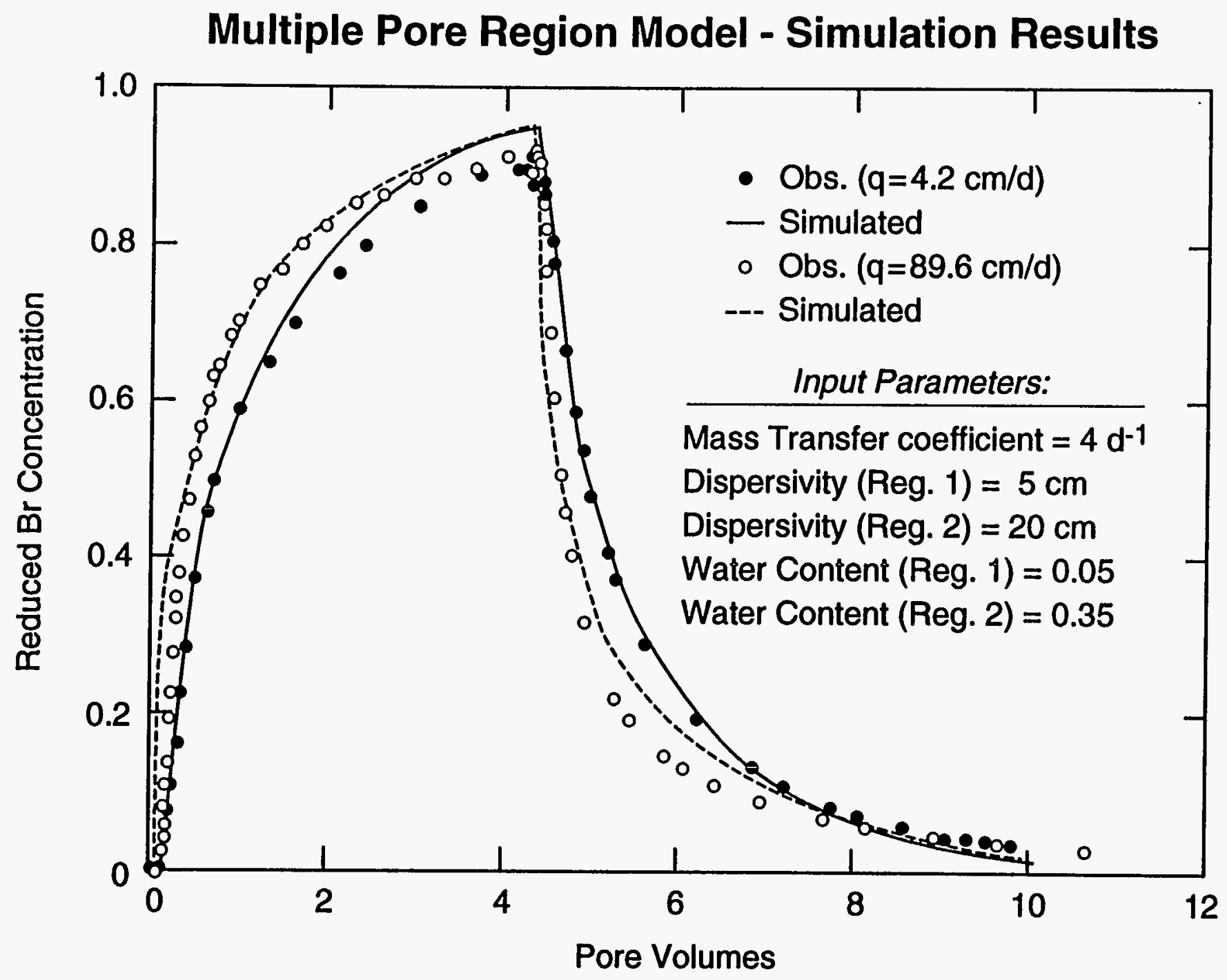

Fig. 3.4. Observed and model simulated effluent concentrations for $\mathrm{Br}$ displacement through undisturbed weathered shale at two pore water velocities. Differences in the observed breakthrough curves were the result of nonequilibrium conditions in the flow field as the tracer slowly diffused from preferential flow paths into the surrounding matrix. 
Recently, specific discharge measurements were performed on the wells at the study site to locate the rapid and slow flowing regimes of the subsurface material, as shown in Fig. 3.5. As had been hypothesized, a rapidly flowing fractured zone was located in each well and found to be oriented along geologic strike. This fractured interval probably serves as the main conduit for the transport of ${ }^{3} \mathrm{H}$ and possibly ${ }^{90} \mathrm{Sr}$ from the waste trenches to the nearby stream.

\subsubsection{Modeling studies}

Various modeling approaches for quantifying contaminant movement in the complex subsurface regimes found at ORNL have been evaluated. The transport models utilized in this study incorporate fracture flow coupled with matrix diffusion or incorporate multiregion flow and transport with diffusion of contaminants occurring between regions. The latter model can handle contaminant redistribution during flow interruptions and is well suited for field-scale simulation. Specifically, the model simulates multiregion flow and solute transport where the voids in the soil/rock can be divided into an arbitrary number of pore groups. Each pore group (region) has a unique flow field while interchanging fluid and mass with the other pore groups. The model is designed for 1-,2-, and 3-dimensional laboratory- or field-scale contaminant transport problems that are complicated by fracture flow. The diffusive exchange of solute between regions is driven by a linear concentration difference. For the purposes of this study, we have used the model as a dual porosity simulator of flow and transport within fracture-matrix regimes. Numerical parameterization of the model will be based on laboratory and field measurements and experimental data acquired from an uncontaminated site near WAG 5 over the past 4 years (Jardine et al. 1988, 1993; Wilson et al. 1992, 1993; Gwo et al. $1994 \mathrm{a}, \mathrm{b}$ ). After the parameters have been identified the model will be used to investigate the significance of primary and secondary sources of ${ }^{3} \mathrm{H}$ and ${ }^{90} \mathrm{Sr}$ to the observed contamination discharged along the perimeter of WAG 5.

\subsubsection{Benefits to remediation}

About 10 years ago the hydrogeological regime at ORNL seemed to be so hopelessly complex that the prospect of ever realistically modeling the movement of contaminants seemed to be unlikely. Since then the outlook has changed. The results of this investigation when combined with those of other ongoing studies will produce reliable, predictive groundwater models. Results and data from this project will be directly transferred to ORNL site clean-up activities and aid in the design of remedial actions. There will also be benefits to the design of groundwater monitoring systems and to the interpretation of monitoring measurements. The results of this research continues to provide a more thorough understanding of the actual transport mechanisms and better modeling tools, so that remediation concepts are not limited to a purely empirical approach. In turn, the improved predictive capabilities of subsurface contaminant transport will allow engineers to develop remediation strategies targeted at specific problems and with a higher probability of success.

\subsection{SUMMARY}

During FY 1994 groundwater data collection activities at ORNL included ongoing sampling and analysis of wells at WAG perimeters; investigations related to the Remedial Investigation of WAG 5; well sampling, analysis, and water level data collection at WAG 1 under a post-Phase $1 \mathrm{RI}$ monitoring activity; water level monitoring at wells throughout the 
ORNL-DWG 94M-10044

\section{Transect from Injection Well to Seep Source Area A, WAG 5 (20 drive point wells)}

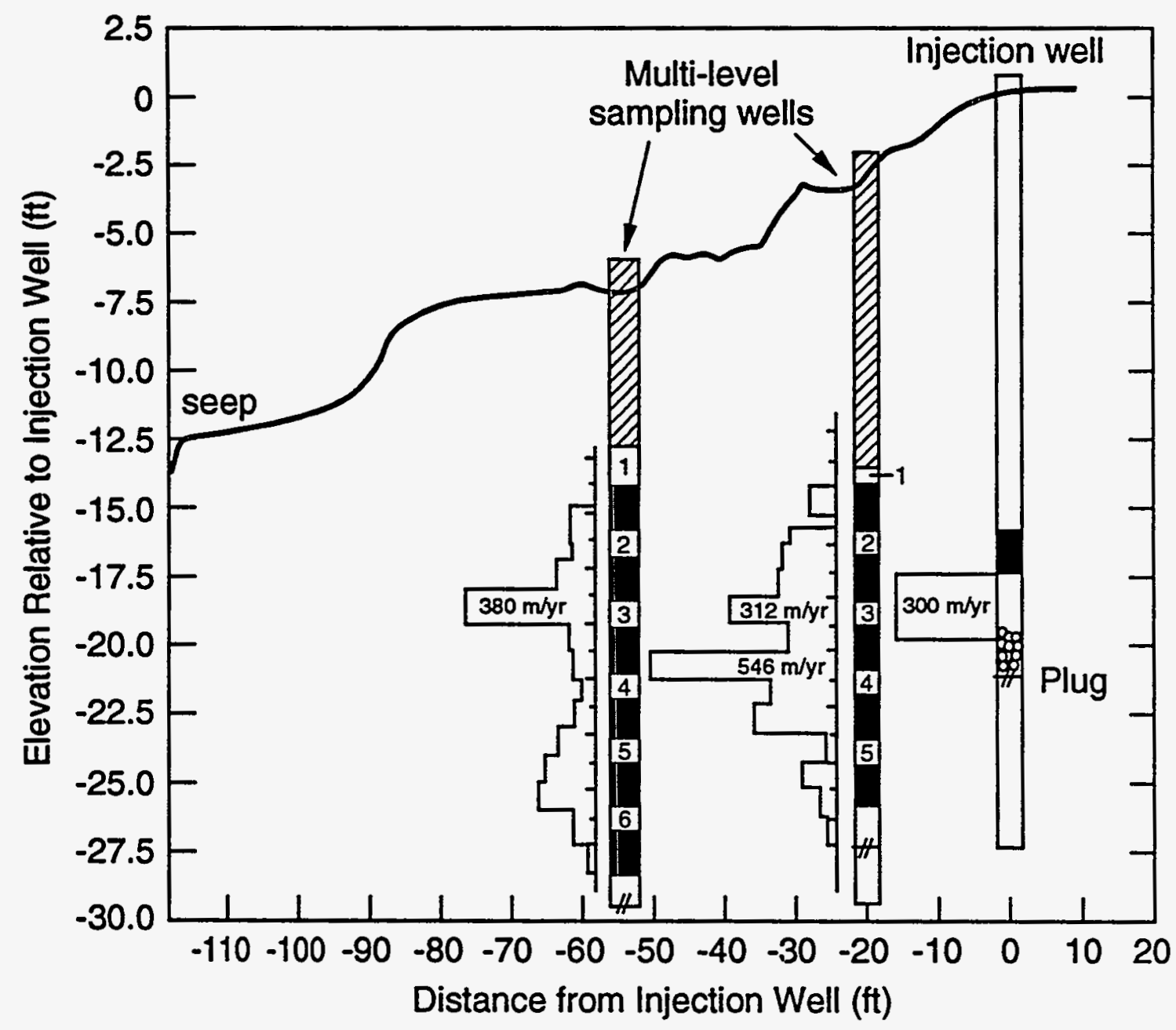

Fig. 3.5. Two-dimensional cross-section of the tracer injection site at Waste Area Grouping 5 showing the injection and multilevel sampling wells. Groundwater specific discharge measurements show the rapidly flowing fractured zone where the $\mathrm{Br} / \mathrm{He} / \mathrm{Ne}$ tracers will be injected. Monitoring at nearby drive point wells and the seep will enhance the spatial and temporal monitoring of the tracers. 
ORNL site under the WAG 2 monitoring project; and hydraulic head measurement at 13 Hydrostatic Head Measurement Stations. During FY 1994 a monitoring plan for the WAG 6 site was developed and implementation of that monitoring will occur late in FY 1994 and will continue through FY 1995 and beyond.

Individual wells at WAGs $1,2,6,7$, and 17 have carcinogen risks greater than $1 \times 10^{-3}$, and multiple wells at WAGs 5 and 4 have risks in this risk range. WAGs 1 and 6 have numerous perimeter monitoring wells which fall into the $1 \times 10^{-4}$ order of risk. All but one WAG perimeter monitoring well have greater than $1 \times 10^{-6}$ risk based on the average detected contaminant levels. The highest levels of risk associated with groundwater contaminants are along the downgradient perimeters of WAGs 4 and 5.

Contaminants that contribute the total carcinogenic risk in groundwater at ORNL can be categorized as belonging to one of three families of contaminants-radiological contaminants, metals, or organic compounds. Radiological contaminants, particularly total radiological strontium and tritium, dominate the groundwater risk calculations at ORNL. Organic compounds contribute significantly to risk at some wells. Beryllium is detected often in the data set but as an individual analyte typically occurs at risk levels of $5 \times 10^{-5}$ or less.

The time-history plots of total risk and contaminant specific risk in groundwater show that at many wells the contaminant concentrations are stable for practical purposes and that some wells show increases or decreases in contaminant concentrations. No general statement accurately describes the changes of potential risk or contaminant concentration at ORNL.

Modeling activities are currently addressing several groundwater-related issues that are important for the ER Program. Groundwater models have been used to estimate the groundwater flux leaving WAG 6, which is important to estimating the overall discharge of contaminants from the WAG. Modeling shows how impermeable caps to not ensure hydrologic isolation due to lateral shallow subsurface stormflow. Development of regional models using super computers and fracture-flow models that depict the complex mechanisms of transport expand our understanding of groundwater systems and our predictive capabilities. The Waterloo fracture-flow model will be applied to ${ }^{90} \mathrm{Sr}$ discharges associated with the Corehole 8 site in WAG 1.

Extensive laboratory experiments using tracers flowing through undisturbed cores of weathered shale have confirmed basic elements of the conceptual hydrologic model. Preferential flow in macropores combined with the effects of matrix diffusion have been demonstrated and quantified. These mechanisms that affect the movement of contaminants are important to the performance of remedial actions. If only primary sources (waste burial trenches) are remediated then secondary sources that are not remediated may release contaminants to streams for years, even decades. These mechanisms are currently being investigated at the field scale at the Seep A area below WAG 5. This work is being concurrently modeled with an innovative fracture-flow model developed at the University of Waterloo. These investigations will yield more realistic and reliable groundwater models in the future and better information for ER decision and for remedial action designs. 


\title{
4. SOIL AND SEDIMENT
}

\author{
B. B. Burgoa, R. D. Clapp, T. A. Fontaine, T. D. Moore, K. M. Turnage
}

\subsection{INTRODUCTION}

Contaminated soil and sediment in WAG 2 at ORNL provides a potentially significant pathway of exposure for humans and for the environment (see Table A.1 in ERMA 1993). The erosion of contaminated soils in the waste disposal areas mobilize particle-reactive contaminants, and the subsequent deposition of these eroded sediments can cause accumulation of contaminants, leading to potentially unacceptable exposures to humans and biota. Deposition of sediment can also interfere with the function of weirs and change the hydrodynamic characteristics of the surface water system. Characteristics of soils and sediments in the ORNL WAGs influence remedial actions (e.g., treatability, construction, removal). Soils and sediments eroded from uncontaminated areas become contaminated as they enter contaminated areas (e.g., WAG 1 and WAG 2); thus sediment from both contaminated and uncontaminated areas are of concern.

The key environmental problem associated with the contaminated sediments stored in the WAG 2 floodplain and on the bottom of White Oak Lake is the possibility of an extreme flood mobilizing those contaminants (mainly ${ }^{137} \mathrm{Cs}$ ) and depositing them in the Clinch River, possibly resulting in unacceptable risk to human health downstream of ORNL. Although contaminated sediments released to the Clinch River tend to be deposited in deep water or move through the river system with continual dilution, there are scenarios such as dredging where an off-site person may be exposed to contaminated material. The probability of an extreme storm (or a series of storms) leading to an unacceptable off-site risk is considered to be extremely low, but that probability must be documented. The probability can only be estimated through understanding and modeling the sediment transport processes and climatic conditions that drive the system.

In addition to the probability of any unacceptable risk there is the issue of stewardship of the WAG 2 system, which contains approximately $1200-1500 \mathrm{Ci}$ of ${ }^{137} \mathrm{Cs}$ and other contaminants (Blaylock et al., 1993). Although risk considerations are the main drivers of the ER Program, stewardship also may become important. Potential release of several curies of ${ }^{137} \mathrm{Cs}$ may be deemed to warrant mitigating actions (new downstream sampling or modifications to flows in the Clinch River by Tennessee Valley Authority) independent of the actual risk posed by the potential release. Information gathered as part of this task will assist in stewardship of WAG 2.

Knowledge of the types and distribution of on-site contamination in soils and sediments is important for determining on-site risk to human health and ecological risk. The current actual on-site risk is maintained at low, acceptable levels by restricting access to WAG 2 and other contaminated sites. Worker safety is ensured by administrative controls and safe work practices. Data collected in this task assist ER staff in defining worker risks and developing appropriate safety plans. 
The data summarized in this section are collected within the Soil and Sediment Task within the WAG 2/SI Project. The data were collected both for initial site characterization within WAG 2 and as input to a computer model to evaluate the potential for off-site transport of contaminated sediments. The computer model being used is the Hydrologic Simulation Program-Fortran Model.

Section 4.2 describes the conceptual model of contaminated sediment transport in the White Oak Creek watershed. The basic assumption of the model is that relatively small floods erode hillslopes and stream banks, and that the sediment is transported to weir pools and White Oak Lake where it becomes a secondary source susceptible to mobilization in much larger floods.

Section 4.3 summarizes the sediment transport data collected during the storm that occurred in December 1993. The data yield a complex picture because results are not consistent for two relatively large storms for which data have been processed.

Section 4.4 describes activities to identify and quantify inventories of contaminated sediments in the White Oak Creek system, especially the sediments deposited in the weir pools of the main monitoring stations.

Section 4.5 describes two special studies of the erosion rates in the watershed. The first study deals with erosion in the stream channel banks, and the second focusses on hillslope erosion.

Section 4.6 provides a summary of Sect. 4.

\subsection{CONCEPTUAL MODEL FOR CONTAMINATED SEDIMENT TRANSPORT}

A diagram of the conceptual model for contaminated sediment transport in the White Oak Creek basin is shown in Fig. 4.1. The Soil and Sediment Task has data collection activities related to most of the components of the conceptual model. Other components of the conceptual model are investigated by other portions of the WAG 2/SI Project to generate a comprehensive picture of contaminant movement in the hydrologic system.

\subsubsection{Sediment Sources}

Hillslope erosion is important to overall sediment budgets. Uncontaminated hillslope sediment entering the White Oak Creek channel system will be mixed with particle-reactive contaminants as it moves downstream. The increased volume of contaminated material could lead to unacceptable exposures and to greater amounts of soil/sediment to be remediated. Consequently, the erosion of surface soil and stream channels in uncontaminated regions impacts remediation efforts. The task team has measured erosion rates in nearby uncontaminated sites using naturally occurring ${ }^{137} \mathrm{Cs}$ as reported in Sect. 4.5. 


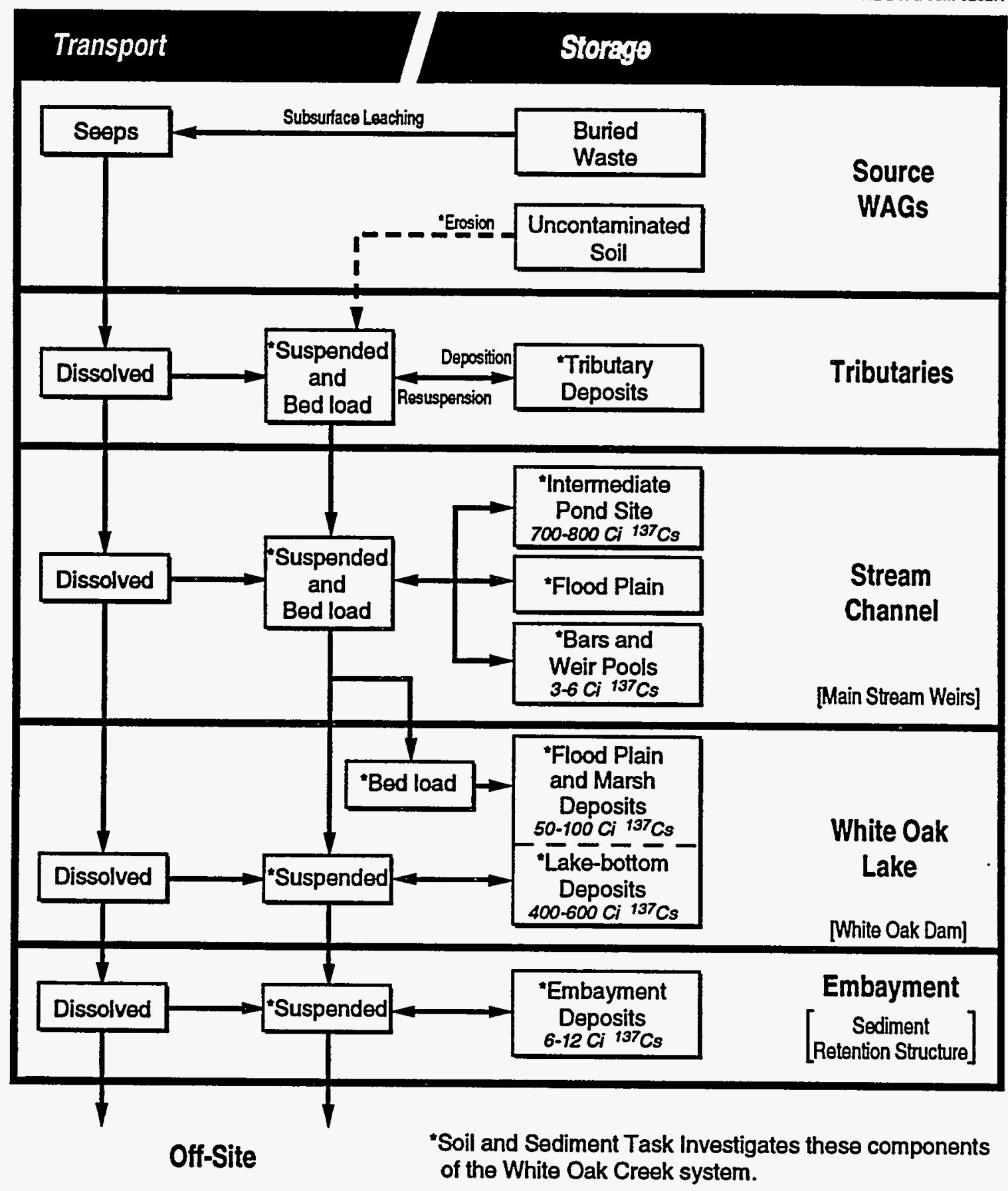

Fig. 4.1. Conceptual model for contaminated sediment transport in the White Oak Creek basin. 


\subsection{Primary Contaminant Sources}

Contamination in the White Oak Creek/White Oak Lake system is a result of subsurface releases from active and inactive sites in 11 WAGs located within the White Oak Creek watershed. Seepage of dissolved contaminants is addressed by the Surface Water and the Groundwater Operable Unit Teams. Particle-reactive contaminants bind to sediments and move through the White Oak Creek drainage system. The primary contaminant in the main streams and White Oak Lake is ${ }^{137} \mathrm{Cs}$, which is rapidly and tightly fixed to soils and sediments. Other contaminants of concern associated with soils and sediments are ${ }^{60} \mathrm{Co},{ }^{234} \mathrm{U}$, PCBs, arsenic and thallium found in the White Oak Creek floodplain system and White Oak Lake, as well as ${ }^{152} \mathrm{Eu}$ found in the White Oak Creek Embayment sediments.

\subsection{Deposition and Secondary Sources}

Much of the sediment is transported through the White Oak Creek system by a cycle of erosion, transient suspension, and deposition. The cycle may be repeated many times before a sediment particle is discharged from White Oak Creek into the Clinch River. Within the system, all deposited materials become potential secondary sources of contamination. Resuspension can occur when severe storms lead to higher discharge velocities. The major sources of mobile contaminated sediment during flood events are these contaminated sediment deposits in the stream channels and floodplains, as indicated in Fig. 4.1. The estimated inventory of ${ }^{137} \mathrm{Cs}$ in WAG 2 is $1200-1500 \mathrm{Ci}$ based on reports by Lomenick and Gardiner (1965), Oakes et al. (1982), Sherwood and Loar (1987), and Blaylock et al. (1993). Two goals of the Soil and Sediment Task are to verify or update the inventory of the contaminants of all secondary sources in the watershed and to measure or estimate their relative susceptibility to resuspension. A key assumption is that both the particle size and the cohesiveness of the sediments control the resuspension of secondary sources during floods.

\subsubsection{Transport Processes}

Increasing stream flow (discharge) generates increasing shear stresses on the channel bottom and stream banks and on the floodplain soils during floods. When the critical shear stress for the channel or soil material is exceeded, scour or erosion is initiated; and suspended sediments are entrained in the stream flow depending on the erodibility of the sediment. Although there is extensive information on the critical shear stress and erodibility of sands, there is little information concerning these important parameters in cohesive sediments such as those found in WAG 2.

In the conceptual model, the White Oak Creek watershed has several locations where contaminated sediments accumulate, thereby becoming secondary sources for a future mobilization during floods. Moderate floods (1- to 10-year events) may carry particles from clays to fine sands through the weir pools and White Oak Lake but will deposit coarse sands and gravels, transported as bedload, in the larger weir pools and in White Oak Lake. Extreme floods (20- to 100-year events) may develop enough energy to scour out significant amounts of the sediment deposits at weir pools and in the White Oak Lake bed. Therefore, the basic assumption is that the smaller floods tend to accumulate sources of sediment which are then scoured and carried off-site into the Clinch River during larger floods. 


\subsection{SEDIMENT TRANSPORT}

\subsubsection{Storm Sampling Events}

During flood conditions Sediment Transport Task field staff intensively sampled surface water to determine the discharge of suspended sediments and associated particle-reactive contaminants. The main purposes of this data-collection effort are (1) to assist in the understanding of the processes whereby contaminants are mobilized and transported off site, (2) to generate the data base needed to calibrate the Hydrologic Simulation Program-Fortran model, and (3) to evaluate the accuracy of the monthly discharge measurements for ${ }^{137} \mathrm{Cs}$ made by the Office of Environmental Compliance and Documentation. These monthly data form the long-term record of contaminant discharge used by the ER Program to evaluate risk to the off-site population and to prioritize remedial actions.

Data collection activities during storms consist of retrieving surface water samples collected by automatic samplers and by manual sampling. Suspended sediment concentrations measured in manual samples provide a check of the measurements generated by the automatic sampler. Because sediments are generally known to be unevenly distributed both vertically and horizontally in a stream and because automatic sampler intake is positioned at fixed points within the stream, automatic samples can be biased (e.g., too much or too little coarse material). Consequently, manual samples taken across the stream profile and composited are assumed to provide a more accurate measure of suspended sediment loads and are a check of the automatic sampler measurements.

Four storms were sampled in 1993 as part of the Sediment Transport Task. The results of the first three storms, identified as 24JAN93, 21FEB93, and 23MAR93 were summarized in ERMA (1993). Results for the storm of 04DEC93 are summarized in this section. Samples were collected during three storms early in 1994, but the data analyses have not been completed.

It is desirable to rate peak runoff according to the frequency or return period. For an extreme event such as a flood, the annual frequency is the reciprocal of the return period. There are insufficient historical records for White Oak Creek discharge at White Oak Dam to determine peak-flow return periods. Therefore, sampling events are based on precipitation frequencies. Precipitation return periods cannot be directly translated into peak flow return periods. A 20-year 24-h precipitation event does not imply that a 20-year peak flow occurred. Other factors, particularly antecedent moisture content, affect peak flow during a storm. Nevertheless, because reliable estimates of the probability distribution of peak discharges are not available, it is useful to rate the storms by return period. In this section storm return periods are based on a recent statistical analysis of the precipitation record at the Oak Ridge township raingage located at the National Oceanic and Atmospheric Administration facility.

\subsubsection{Analysis of the 04DEC93 storm event}

For the storm of 04DEC93 the First Creek raingage recorded 4.40 in. of precipitation over $24 \mathrm{~h}$, which is rated as a 5-year storm event. The peak flow return period may be longer due to nearly saturated antecedent conditions caused by previous storms. For comparative purposes, storms on 24JAN93, 21FEB93, and 23MAR93 that were sampled earlier had return periods of less than 2 years. During the $04 \mathrm{DEC} 93$ storm approximately 500 samples were collected manually and automatically at the sampling sites (Fig. 4.2) and subsets of samples 


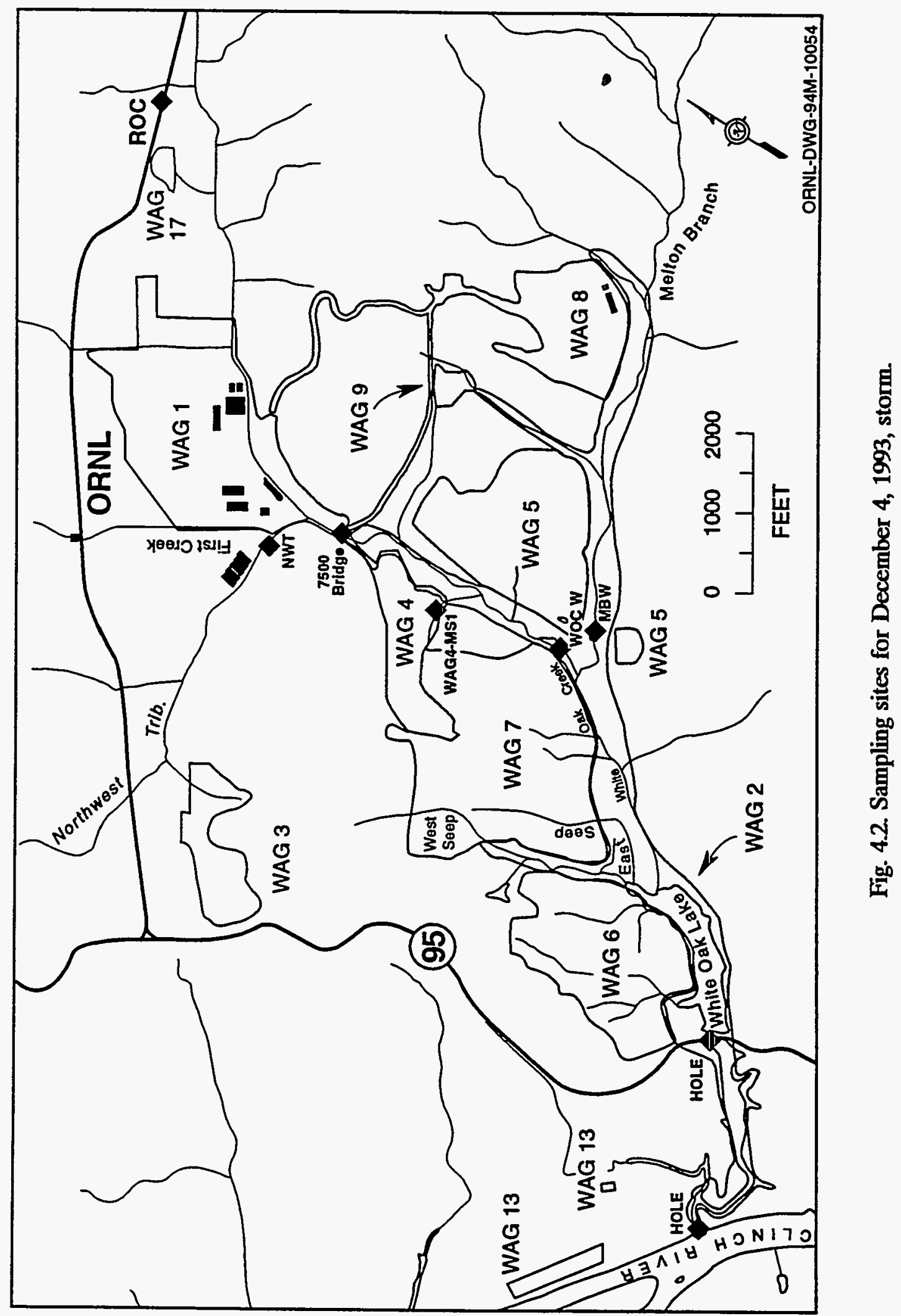


were selected for determination of suspended sediment concentration, ${ }^{137} \mathrm{Cs}$ concentration on the sediment particles, and sediment size-grain distribution.

\subsubsection{Hydrographs and Sediment Loads}

Hydrographs for monitoring stations WOCWEIR and MBWEIR had two peak flows with the second having the largest flow (Figs. 4.3-4.4). In contrast, peak suspended sediment concentrations occurred during the first peak flow while a smaller peak suspended sediments occurred during the second peak flow at both sites. This pattern is probably caused by the earlier flows flushing the lighter, more mobile sediments through the system, leaving less material for a slightly larger flow to flush.

To determine the sediment discharge at White Oak Dam, a 4h segment of the sample record had to be estimated because of the lag time between changes of the sample bottles at the monitoring station. The missing data were estimated from samples collected at White Oak Creek Embayment site. The missing data most likely fell within the envelope range shown in Fig. 4.5, yielding minimum and maximum estimates of the discharged suspended sediments. These values can be used to determine the range at which sediment deposition occurred within the Lower White Oak Creek and White Oak Lake Reach (Table 4.1).

Table 4.1. Estimates of sediment discharge and accumulation in the Lower White Oak Creek and White Oak Lake Reach

\begin{tabular}{cccc}
$\begin{array}{c}\text { Sediment inflow to Lower } \\
\text { White Oak Creek and White } \\
\text { Oak Lake }\end{array}$ & $\begin{array}{c}\text { Sediment discharge at } \\
\text { White Oak Dam }\end{array}$ & Mass & Fraction \\
\cline { 3 - 4 }$(\mathrm{Mg})$ & $(\mathrm{Mg})$ & $(\mathrm{Mg})$ & $\%$ \\
\hline $\begin{array}{c}\text { WOCWEIR }+\mathrm{MBWEIR}= \\
67.5+56.5=\end{array}$ & $\begin{array}{c}\text { (Minimum estimate) } \\
51.3 \mathrm{Mg}\end{array}$ & 72.7 & 59 \\
$124.0 \mathrm{Mg}$ & & & \\
& & & \\
& (Maximum estimate) \\
$59.2 \mathrm{Mg}$ & 64.8 & \\
\hline $\mathrm{Mg}=$ Mega gram $=10^{6} \mathrm{~g}$. & & &
\end{tabular}

The results show that Melton Branch, which drains only $29 \%$ of the area above the confluence with White Oak Creek, produced a disproportionately large fraction (45\%) of the total sediment discharged to the Lower White Oak Creek and White Oak Lake Reach. The source of sediments is unknown. The watershed is mostly vegetated with forest, but there are some grasslands associated mostly with WAG 5 that may be susceptible to erosion, and there are several areas with pavement and buildings where intense runoff may result in erosion. One possible source is the sediments that nearly fill the pool behind the Melton Branch weir. 


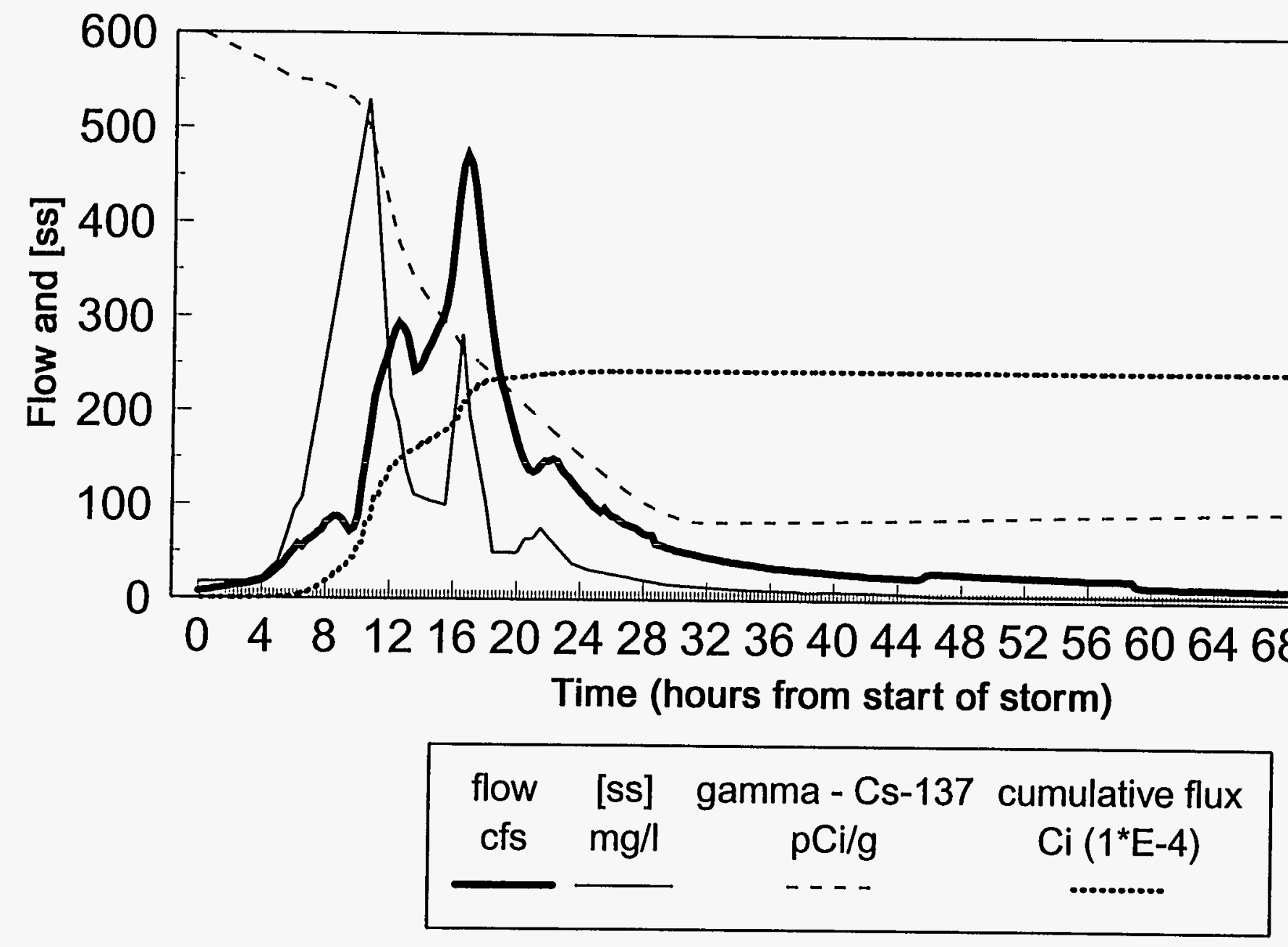

Fig. 4.3. Storm analysis at White Oak Creek weir for December 4, 1993. 


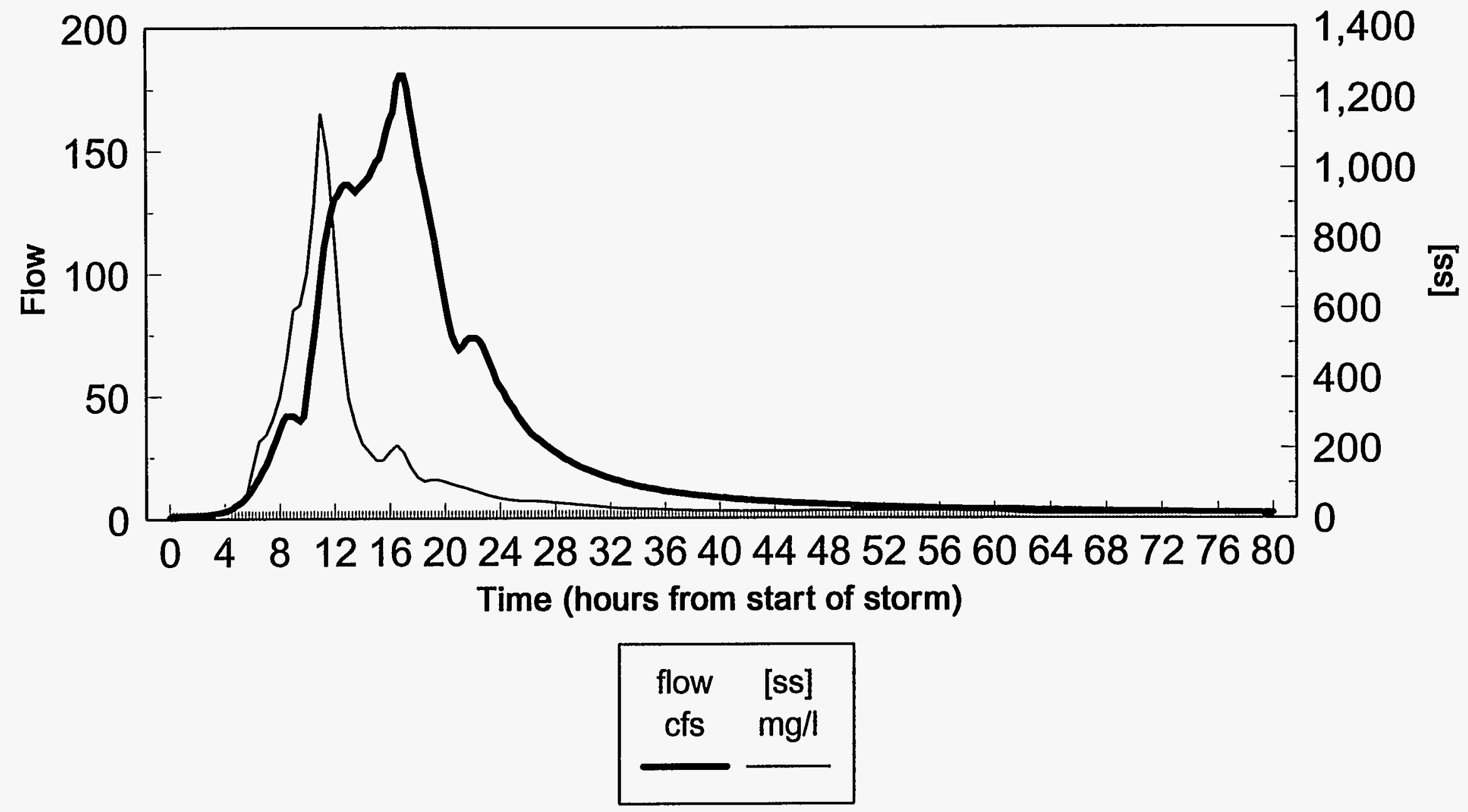

Fig. 4.4. Storm analysis at Melton Branch weir for December 4, 1993. 


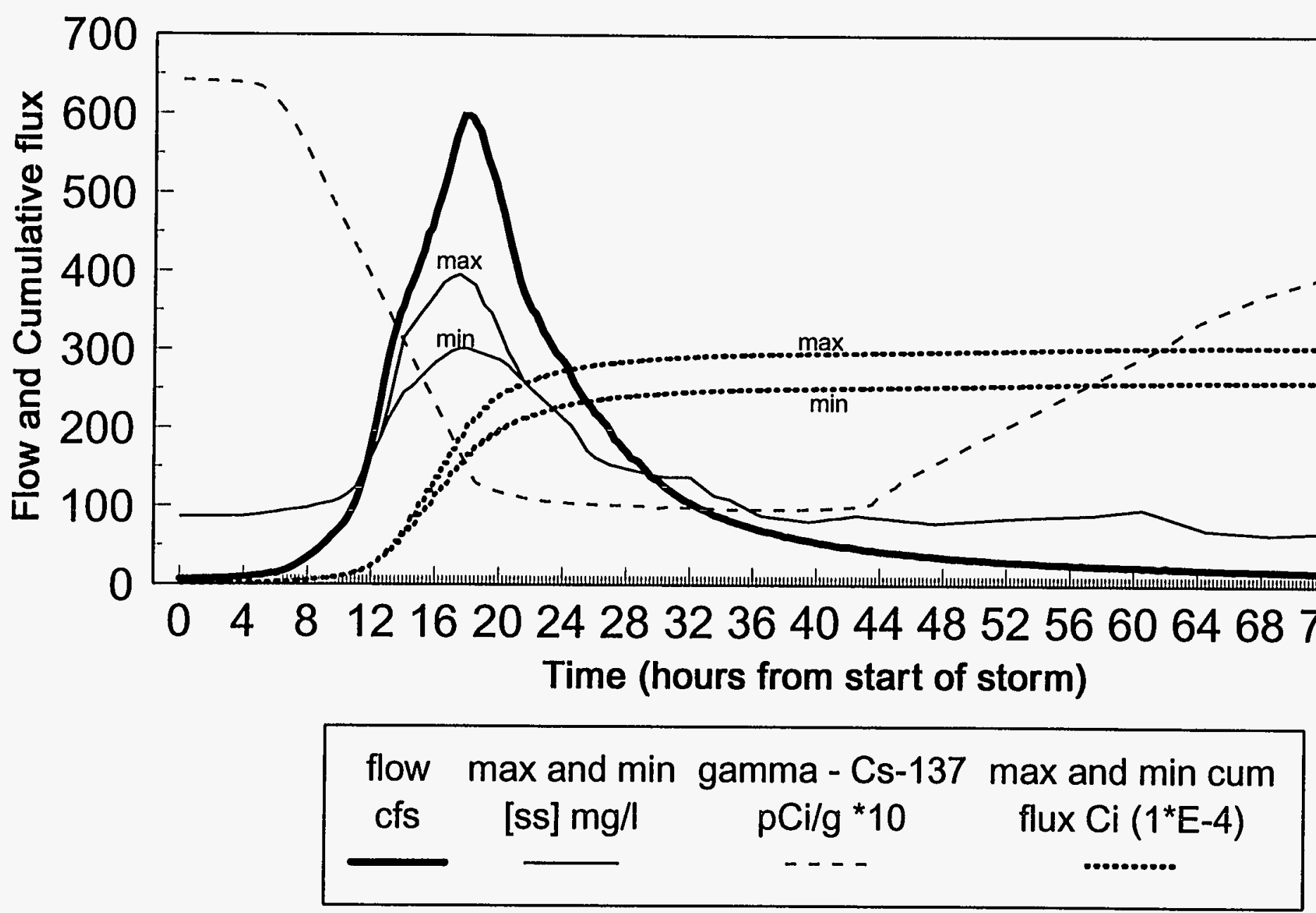

Fig. 4.5. Flow, suspended sediment concentration [ss], gamma, and cumulative flux with respect to time. 
Sediment loading at that pool is discussed in the following paragraph.

Automatic samplers collect water samples above and below the weir pools at WOCWEIR and MBWEIR (Figs. 4.3 and 4.4). The sample record collected upstream of the weir pools is incomplete because these sites are inaccessible during floods, and all sample bottles were filled early. Upstream samples were collected from about 0800 to $1400 \mathrm{~h}$, which included the first and largest suspended sediment peak. The net deposition in the weir pool at Melton Branch cannot be estimated for the entire storm. However, for the 6-h period when the automatic sampler operated $37 \mathrm{Mg}$ of sediment was discharged downstream at Melton Branch or $66 \%$ of the total suspended sediment for the entire storm. During this $6-\mathrm{h}$ period over 7 $\mathrm{Mg}$ was also deposited in the Melton Branch weir pool, an indication that the weir pool was probably accumulating sediments during the storm despite its nearly full condition.

Table 4.2. Sediment accumulation in stilling pools at the WOCWEIR and MBWEIR during the initial $6 \mathrm{~h}$ of the 04DEC93 storm

\begin{tabular}{|c|c|c|c|c|}
\hline \multirow[b]{2}{*}{ Location } & \multirow{2}{*}{$\begin{array}{c}\text { Sediment inflow to } \\
\text { weir pools }\end{array}$} & \multirow{2}{*}{$\begin{array}{l}\text { Sediment } \\
\text { discharge }\end{array}$} & \multicolumn{2}{|c|}{ Accumulation } \\
\hline & & & Mass & Fraction \\
\hline & $(\mathrm{Mg})$ & $(\mathrm{Mg})$ & $(\mathrm{Mg})$ & $\%$ \\
\hline WOCWEIR & 36.9 & 23.6 & 13.3 & 36 \\
\hline MBWEIR & 44.6 & 37.4 & 7.2 & 16 \\
\hline
\end{tabular}

$\mathrm{Mg}=$ Mega gram $=10^{6} \mathrm{~g}$.

\subsubsection{Contaminant Analysis}

Figures 4.3-4.5 show the flow, suspended sediment concentration, ${ }^{137} \mathrm{Cs}$ concentration on the sediment, and cumulative flux for ${ }^{137} \mathrm{Cs}$ at the three main weirs that feed and drain White Oak Lake. Cesium-137 is typically below detectable limits at the MBWEIR (Fig. 4.4). Based on the minimum and maximum estimates of sediment discharge at White Oak Dam (Table 4.1) the computed ${ }^{137} \mathrm{Cs}$ load discharged from White Oak Dam ranged from 0.026 to $0.031 \mathrm{Ci}$, respectively. The average value of $0.0285 \mathrm{Ci}$ is the best overall estimate. As shown in Table 4.3, about $77 \%$ of the total ${ }^{137} \mathrm{Cs}$ transported as suspended sediment settled within White Oak Lake and its floodplains.

Data collected by the Office of Environemental Compliance and Documentation indicates the cumulative ${ }^{137} \mathrm{Cs}$ contaminant flux passing White Oak Dam during the week of the $04 \mathrm{DEC} 93$ storm was $0.028 \mathrm{Ci}$, and the ${ }^{137} \mathrm{Cs}$ discharge for the month of December was $0.050 \mathrm{Ci}$. The value for the week is equal to estimate based on intensive sampling over a 3.3-d period analyzed during the storm event. The agreement between the detailed storm measurements and the Office of Environemental Compliance and Documentation weekly 
total is serendipitous, nevertheless, similar agreement for the storm of 23MAR93 (ERMA 1993), strongly suggests that the Office of Environemental Compliance and Documentation values are accurate.

Table 4.3. Comparison of the sediment loads at WOCWEIR, White Oak Dam, and White Oak Lake for two storms

\begin{tabular}{|c|c|c|c|}
\hline Storm & $\begin{array}{c}{ }^{137} \mathrm{Cs} \text { inflow at } \\
\text { WOCWEIR }\end{array}$ & $\begin{array}{c}{ }^{137} \mathrm{Cs} \text { discharge } \\
\text { at White Oak } \\
\text { Dam }\end{array}$ & $\begin{array}{l}\text { Percent deposited in } \\
\text { Lower White Oak } \\
\text { Creek and White } \\
\text { Oak Lake Reach }{ }^{1}\end{array}$ \\
\hline & (Ci) & (Ci) & $(\%)$ \\
\hline $\begin{array}{c}23 \mathrm{MAR} 93 \\
\text { ( } 2 \text { yr. event) }\end{array}$ & 0.082 & 0.044 & 46 \\
\hline $\begin{array}{c}04 \mathrm{DEC} 93 \\
(-5 \text { yr. event })\end{array}$ & 0.122 & 0.0285 & 77 \\
\hline
\end{tabular}

${ }^{1}$ Cesium-137 input from Melton Branch is assumed to be negligible.

The total ${ }^{137} \mathrm{Cs}$ discharge from WOCWEIR during the 04DEC93 storm (5-year frequency) exceeded that of the 23MAR93 storm (2-year frequency); however, the difference in deposition resulted in a lower off-site ${ }^{137} \mathrm{Cs}$ discharge for the larger storm. This difference is unexplained, and the analysis is ongoing. The available data for two storms show that the system is complex and that different processes may predominate in different storms.

\subsubsection{Grain Size Analysis}

Grain size distributions were performed on suspended sediment samples using the Bottom Withdrawal Test. Figure 4.6 compares the peak suspended sediment with grain size fractions at the various locations along the White Oak Creek watershed. As expected, higher concentrations of sand $(>62 \mu \mathrm{m})$ and coarse silts $(16-62 \mu \mathrm{m})$ are transported in reaches upstream from White Oak Lake. Sediments flowing over White Oak Dam are predominately fine silts $(4-16 \mu \mathrm{m})$ and clays $(<4 \mu \mathrm{m})$.

Grain size distributions were measured during the peak suspended sediment discharge for flows entering and leaving the WOCWEIR and MBWEIR stilling pools (Fig. 4.7). The results indicate that a significant proportion of the sand deposited in the weir pools whereas the clays and finer material passed through the system.

Contaminant concentrations per grain-size class (i.e. ${ }^{137} \mathrm{Cs} \mathrm{pCi} / \mathrm{g}$ for sand, coarse and fine silt, and for clay) is a required input for the Hydrologic Simulation Program-Fortran computer model of sediment transport. Measurement of this parameter proved difficult because conventional methods for grain size analysis do not yield satisfactory grain-size fractions 


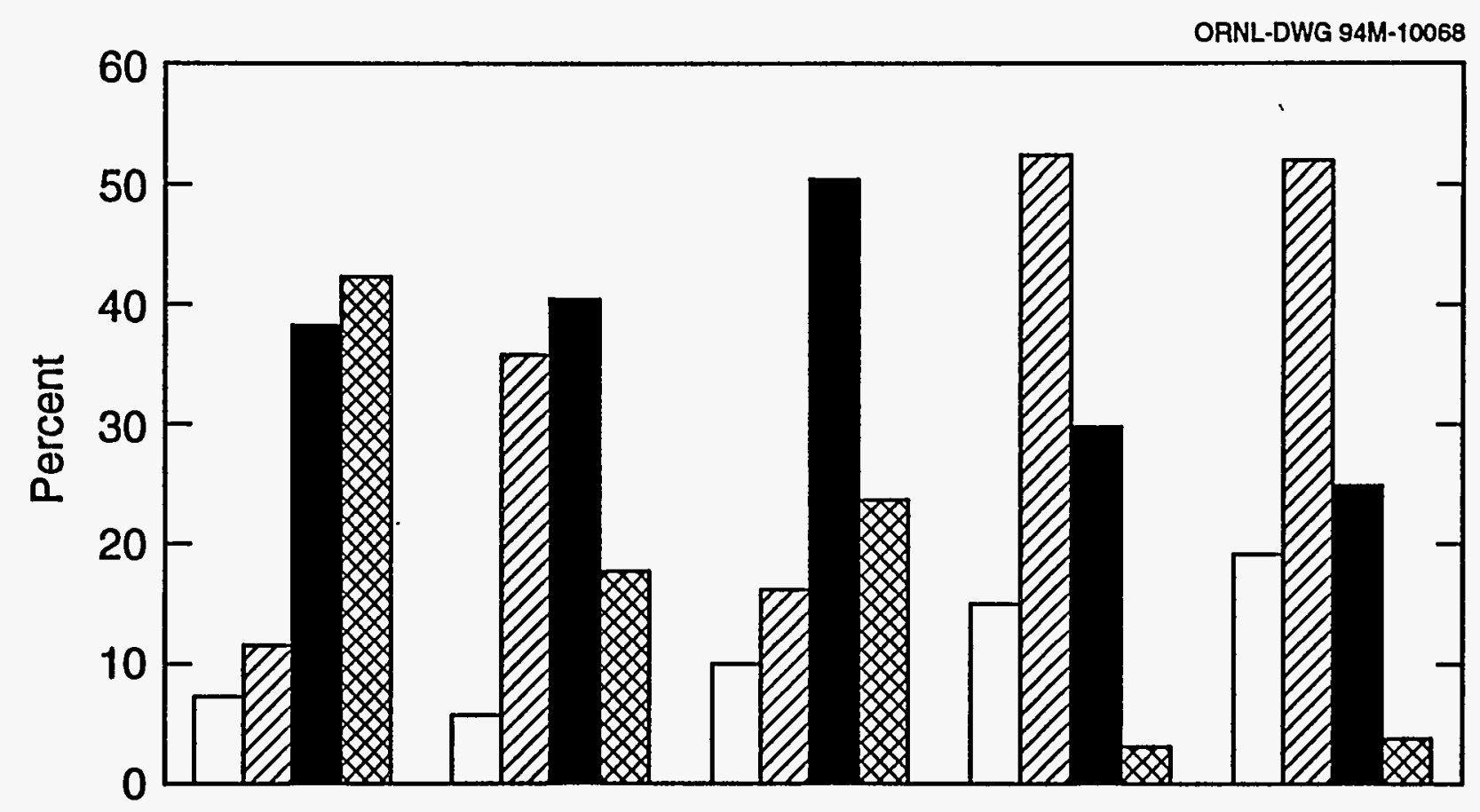

\begin{tabular}{|l|c|c|c|c|c|}
\hline & WAG4-MS1 & WOCW & MBW & WOD & WOCE \\
\hline Clay $\square$ & 7.5 & 5.7 & 10.1 & 14.9 & 19.0 \\
\hline Fine Silt & 11.7 & 35.9 & 16.0 & 52.2 & 52.2 \\
\hline Coarse Silt & 38.3 & 40.5 & 50.5 & 29.9 & 24.9 \\
\hline Sand & 42.5 & 17.9 & 23.5 & 3.1 & 3.9 \\
\hline
\end{tabular}

Samples taken within 1.5 hours of peak suspended sediment concentrations. WOD is average of two simultaneously taken samples.

Fig. 4.6. Grain size comparisons along White Oak Creek for the December 4, 1993 storm. 

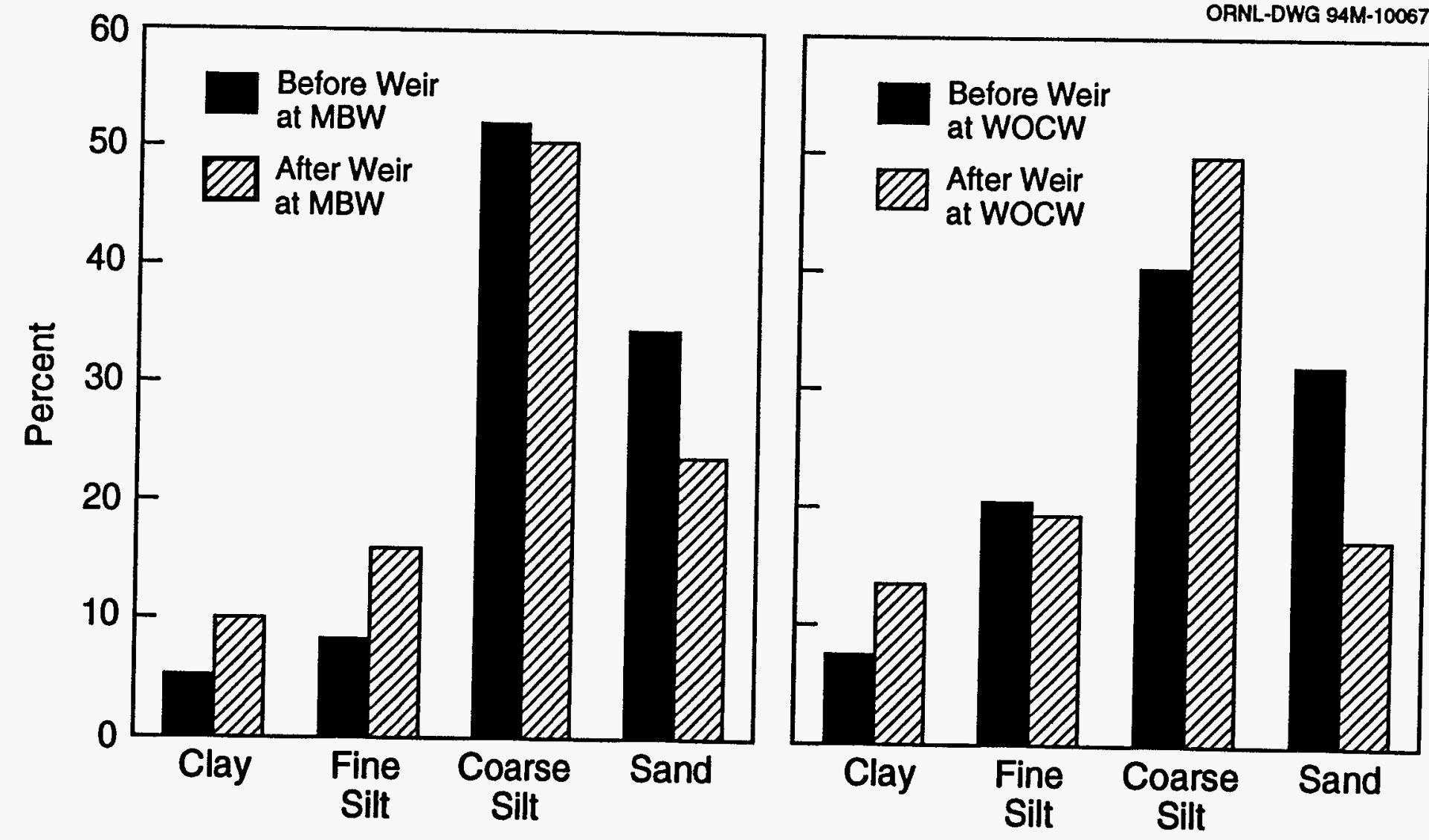

Fig. 4.7. Grain size comparison before and after weir pools at Melton Branch weir and White Oak Creek weir (December 4, 1993, storm). 
(subsamples) for radiological analysis. A new method called the Settling Column Test was developed, and it appears to be promising.

\subsubsection{Summary of Storm Sampling Results}

In the original conceptual model, smaller storms were expected to move sediments from source areas such as hillslopes and small tributary catchments to weir pools and other secondary storage areas. These smaller storms build up secondary sediment sources for off-site transport by relatively larger storms. Of course the breakpoint between small and large is unknown, and it is hoped that storm sampling will yield this kind of information directly. The preliminary analysis of two storms shows a more complex picture because the 5-year storm moved less contamination off-site than the 2-year storm. Further analysis of the existing data is needed as well as analysis of data collected in January and February 1994.

\subsection{CONTAMINANT SOURCES IN WAG 2}

\subsubsection{Floodplain Sampling}

The purposes of floodplain sampling are (1) to identify and, where possible, quantify radioactive and chemical contaminants in areas that may be susceptible to erosion and movement off-site and (2) to update the ${ }^{137} \mathrm{Cs}$ inventory estimates for the floodplain shown in Fig. 4.1. To meet these objectives, begin with limited sampling guided by the results of the walk-over radiation survey (shown in Fig. 4.2 in ERMA 1993). Areas of high radiation are associated with high concentrations of ${ }^{137} \mathrm{Cs}$ and perhaps also with elevated levels of other particle-reactive contaminants. Sample data will be used to identify correlations among several variables: radiation measurements, ${ }^{137} \mathrm{Cs}$, and other contaminants. Correlations, if they exist, between a limited number of soil/sediment data and the walk-over data imply that the walkover data, which covers all of WAG 2 , might be used to estimate contaminant inventories. The phased approach to sampling calls for data from a few soil cores, followed by more sampling guided by preliminary results and ER Program needs.

In January 1994, data from 12 soil cores at the floodplain were collected. Coring sites were located randomly along four transects that ran between White Oak Creek and the edge of the floodplain, as shown in Fig. 4.8.

The data are currently being assessed, but an initial review of the ${ }^{137} \mathrm{Cs}$ concentrations shows a spatial pattern that was expected. In general, the concentrations of ${ }^{137} \mathrm{Cs}$ are greatest near White Oak Creek. They decrease to near background levels at the edge of the floodplain. At each site having elevated levels of ${ }^{137} \mathrm{Cs}$, the concentration of ${ }^{137} \mathrm{Cs}$ generally decreases with depth from a maximum at the surface. For example, Fig. 4.9 shows the three ${ }^{137} \mathrm{Cs}$ profiles for one transect. The surface soils closest to White Oak Creek, which are the most susceptible to resuspension and transport off-site during a large flood, have the largest

${ }^{137} \mathrm{Cs}$ burden. These initial data do not show a layer of clean sediments overlying the ${ }^{137} \mathrm{Cs}-$ contaminated ones.

\subsubsection{Weir Pool Sediment Sampling}

The main objective of the sampling the sediments that have accumulated in the stilling pools behind weir structures in WAG 2 is to characterize particle-reactive contaminants that 
ORNL-DWG 94M-10049

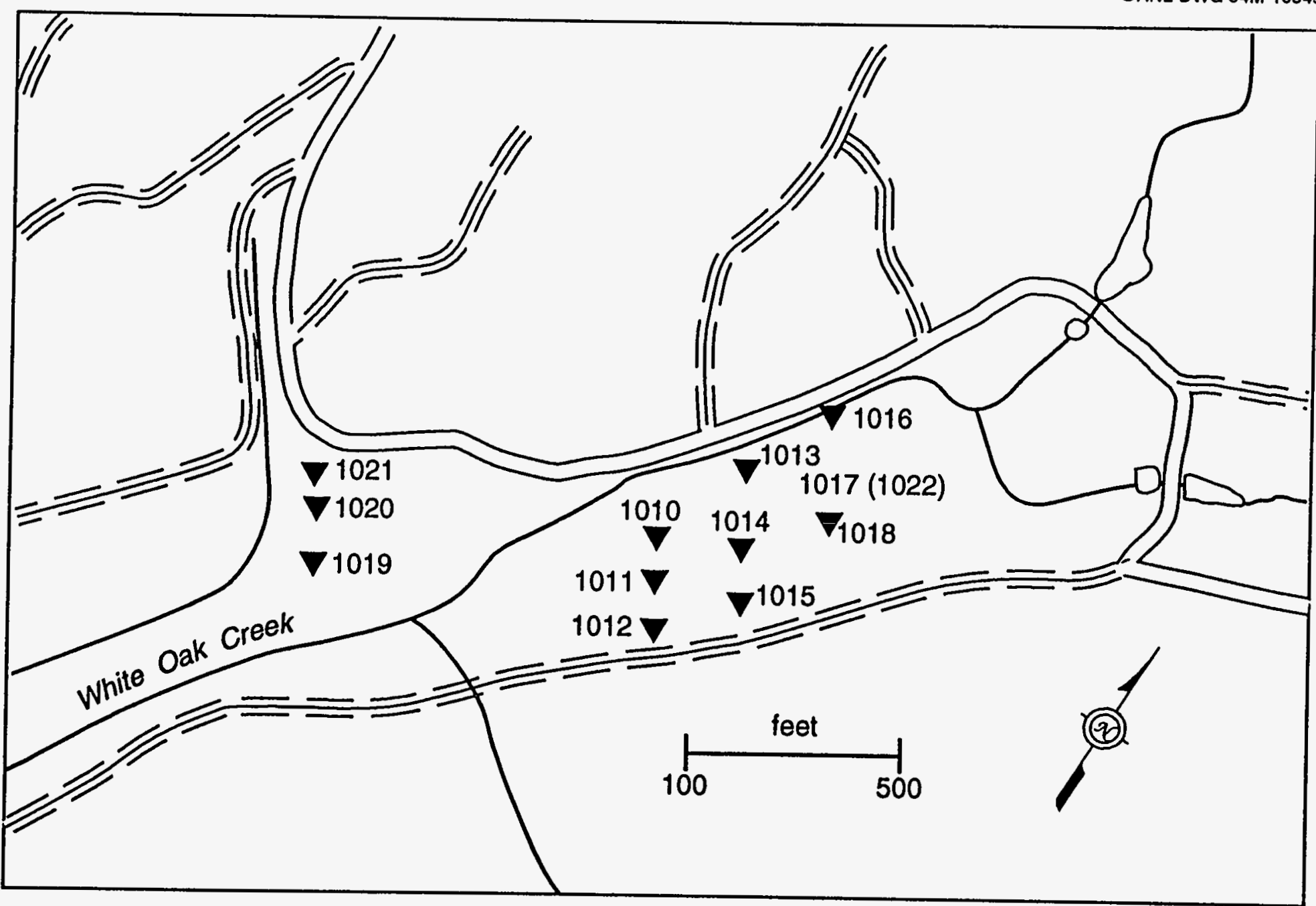

古

Fig. 4.8. Floodplain sampling locations. 


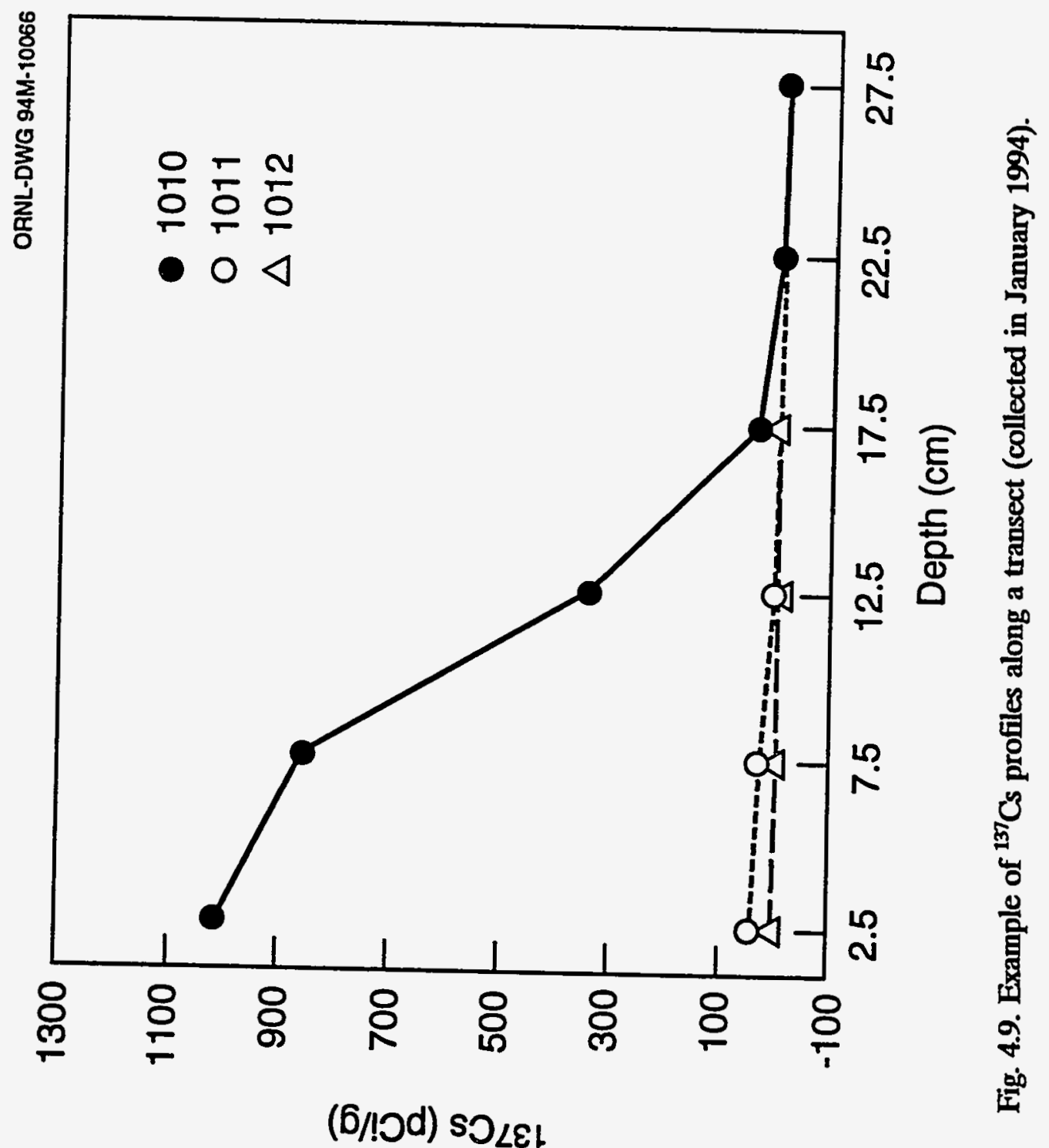


may be mobilized and carried off-site during floods. A secondary objective is to assist in the identification of sources of contamination by tracing contaminants through the watershed.

Twenty-two sediment samples were collected from eight sites shown in Fig. 4.10. The sites were: 7500 Bridge weir, T2A Site, White Oak Creek weir, MB2 weir, MB weir, the White Oak Creek at the inflow point to White Oak Lake, East Seep weir, and West Seep weir. The analytical results were compared with human risk quantification limit concentrations calculated by Blaylock et al. (1993) for sediments and soils in White Oak Lake and White Oak Creek Embayment and the adjacent floodplains. The potential exposure pathways assume effects of gamma radiation and contaminant uptake via direct ingestion of soils/sediments and indirect ingestion via contaminated biota over a 30-year period. These human risk quantification limits are defined as the contaminant levels associated with a $1 \times 10^{-4}$ increased risk of cancer or a Hazard Index Quotient of 1.0. Although some samples from the weir pools exceeded the human risk quantification limits, these sediments are not accessible by the public, and on-site workers are protected by extensive health and safety requirements.

Results show that there is widespread contamination at trace levels in stream sediments in the Melton Valley area; however, the number of sites where human risk quantification limits are exceeded is limited. Contaminants in weir pool sediments that exceed the human risk quantification limits are mainly the two common radionuclides known to be highly sorptive $\left({ }^{137} \mathrm{Cs}\right.$ and $\left.{ }^{60} \mathrm{Co}\right)$, two $\mathrm{PCBs}$, and a few semivolatile organic compounds.

In Table 4.4, the comparison of contaminant concentrations to the human risk quantification limits is summarized; the number of samples exceeding the human risk quantification limits and the maximum concentration for each weir site are listed. The concentration of ${ }^{137} \mathrm{Cs}$ in weir pool sediments exceeds the human risk quantification limits at sites in White Oak Creek below the main plant area and at weir T2A below WAG 4. Both the main plant area and WAG 4 are known to discharge ${ }^{137} \mathrm{Cs}$ (Fig. 3.7 in ERMA 1993). The concentration of ${ }^{60} \mathrm{Co}$ is greatest at the Melton Branch weirs and at East Seep weir. The discharges at the High Flux Isotope Reactor upstream of weir MB 2 are known to have transported ${ }^{60} \mathrm{Co}$ in the past. Also, WAG 7 that drains to East Seep discharges ${ }^{60} \mathrm{Co}$ (Table 3.2). The pattern of radionuclides within the channel network conforms to past observations.

With respect to PCBs, Aroclor-1254 and Aroclor-1260 are the only two PCBs that exceed the human risk quantification limits concentrations at the sample sites. The concentration of Aroclor -1254 is above the human risk quantification limits concentration at 7500 Bridge only. The concentration of Aroclor-1260 is above the human risk quantification limits concentrations at 7500 Bridge and WOCWEIR and in one sample from White Oak Creek above the White Oak Lake, suggesting the main plant area may be the source of PCBs. The PCBs at T2A site could come directly from stream discharge of the WAG 4 tributary but also from the Intermediate Holding Pond or the main plant area because the T2A weir is inundated by White Oak Creek during floods.

All samples that exceed the human risk quantification limits concentrations for semivolatile organics came from sites below the main plant area: 7500 Bridge, T2A, and White Oak Creek. The source of organics at T2A may be WAG 4. These organic compounds tend to be ubiquitous. 


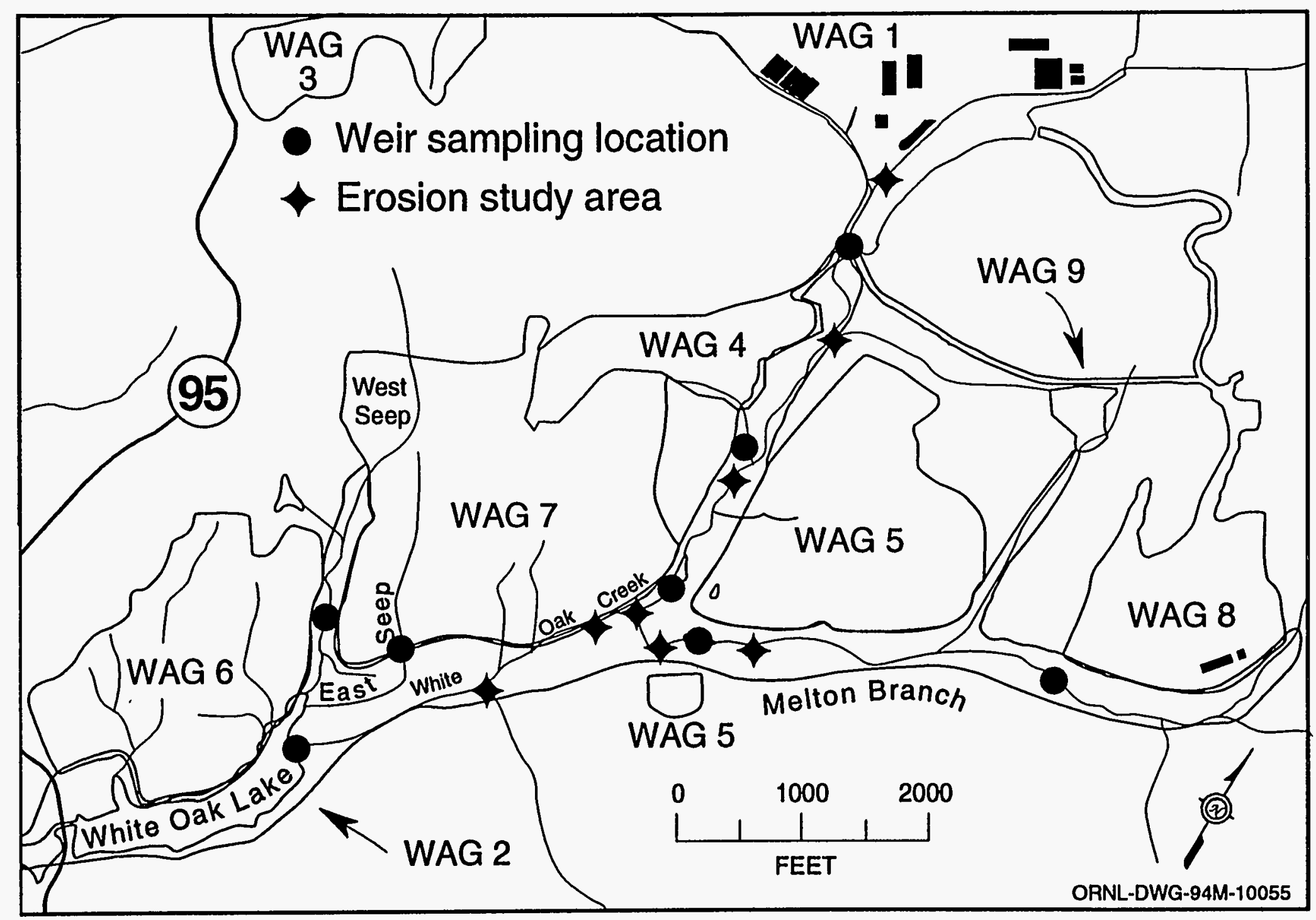

Fig. 4.10. Sediment sampling locations at weir pools and stream erosion study areas. 
Table 4.4 Contaminant Concentrations in Weir Pool Sediments Greater than Risk Criteria

\begin{tabular}{|c|c|c|c|c|c|c|c|c|c|c|c|c|c|c|c|c|c|}
\hline & & \multicolumn{2}{|c|}{7500 BRIDGE } & \multicolumn{2}{|c|}{ WAG 4 T2A } & \multicolumn{2}{|c|}{ WOCWEIR } & \multicolumn{2}{|c|}{$\begin{array}{c}\text { WOC at } \\
\text { WOL }\end{array}$} & \multicolumn{2}{|c|}{ MBWEIR } & \multicolumn{2}{|c|}{ MB2 WEIR } & \multicolumn{2}{|c|}{ WEST SEEP } & \multicolumn{2}{|c|}{ EAST SEEP } \\
\hline \multicolumn{2}{|c|}{ Number of samples per site } & \multicolumn{2}{|l|}{3} & \multicolumn{2}{|c|}{2} & \multicolumn{2}{|c|}{4} & \multicolumn{2}{|c|}{3} & \multicolumn{2}{|l|}{3} & \multicolumn{2}{|l|}{2} & \multicolumn{2}{|l|}{2} & \multicolumn{2}{|l|}{2} \\
\hline & $\mathrm{HRQL}^{1}$ & $\begin{array}{c}\mathrm{N}> \\
\mathrm{HRQL}^{2}\end{array}$ & $\operatorname{Max}^{3}$ & $\begin{array}{c}\mathrm{N}> \\
\mathrm{HRQL}\end{array}$ & $\operatorname{Max}$ & $\begin{array}{c}\mathrm{N}> \\
\mathrm{HRQL}\end{array}$ & $\operatorname{Max}$ & $\begin{array}{c}\mathrm{N}> \\
\mathrm{HRQL}\end{array}$ & $\operatorname{Max}$ & $\begin{array}{c}\mathrm{N}> \\
\mathrm{HRQL}\end{array}$ & $\operatorname{Max}$ & $\begin{array}{c}\mathrm{N}> \\
\mathrm{HRQL}\end{array}$ & Max & $\begin{array}{c}\mathrm{N}> \\
\mathrm{HRQL}\end{array}$ & Max & $\begin{array}{c}\mathrm{N}> \\
\mathrm{HRQL}\end{array}$ & Max \\
\hline Radionuclides & \multicolumn{17}{|c|}{$(\mathrm{pCi} / \mathrm{g})$} \\
\hline Cs-137 & 12 & 3 & 2200 & 2 & 3100 & 4 & 2900 & 3 & 1500 & 3 & 86 & 0 & & 0 & & 1 & 13 \\
\hline Co-60 & 7.4 & 1 & 19 & 2 & 36 & 3 & 32 & 3 & 33 & 3 & 170 & 2 & 210 & 2 & 43 & 2 & 230 \\
\hline PCBs & \multicolumn{17}{|c|}{$(\mathrm{ug} / \mathrm{kg})$} \\
\hline Aroclor-1254 & 67 & 3 & 510 & 0 & & 0 & & 0 & & 0 & & 0 & & 0 & & 0 & \\
\hline Aroclor-1260 & 65 & 3 & 410 & 2 & 91 & 3 & 600 & 1 & 290 & 0 & & 0 & & 0 & & 0 & \\
\hline Organics & \multicolumn{17}{|c|}{$(\mathrm{ug} / \mathrm{kg})$} \\
\hline Acenapthene & 160 & 0 & & 0 & & 1 & 540 & 0 & & 0 & & 0 & & 0 & & 0 & \\
\hline Benzo(a)anthracene & 160 & 1 & 670 & 0 & & 0 & & 0 & & 0 & & 0 & & 0 & & 0 & \\
\hline Benzo(a)pyrene & 710 & $\mathbf{0}$ & & 0 & & 1 & 830 & 0 & & 0 & & 0 & & 0 & & 0 & \\
\hline Benzo(g,h,i)perylene & 230 & 1 & 380 & 0 & & 1 & 570 & 0 & & 0 & & 0 & & 0 & & 0 & \\
\hline Benzo(k)fluorathene & 1.3 & 1 & 630 & 0 & & 0 & & 0 & & 0 & & 0 & & 0 & & 0 & \\
\hline Dibenzo $(a, h)$ anthracene & 170 & 1 & 240 & 0 & & $\mathbf{0}$ & & 0 & & 0 & & 0 & & 0 & & 0 & \\
\hline Fluoronthane & 910 & 1 & 1400 & 0 & & 1 & 1300 & 0 & & 0 & & 0 & & 0 & & 0 & \\
\hline Phenanthrene & 590 & 1 & 940 & 0 & & 2 & 2800 & 0 & & 0 & & 0 & & 0 & & 0 & \\
\hline Pyrene & 880 & 1 & 1200 & 0 & & 2 & 1600 & 0 & & 0 & & 0 & & 0 & & 0 & \\
\hline
\end{tabular}

${ }^{1}$ Human Risk Quantitation Limit, ration of carcinogenic risk relative to $1 \times 10^{-4}$ or ratio of noncarcinogenic Hazardous Index of 1 (unitless). ${ }^{2}$ Number of samples exceeding the HRQL.

${ }^{3}$ Maximum concentration of samples exceeding the HRQL. 
Although pesticides have been detected in biota and sediments in previous studies (ERMA 1992, 1993), no pesticides were detected at the sites above human risk quantification limits.

Many metals were detected in the sediment samples, but only iron and aluminum exceeded the human risk quantification limits. The ORNL discharges may have increased the $\mathrm{Fe}$ and $\mathrm{Al}$ concentrations in the sediments; however, because these metals are constituents of the actual sediment minerals, they are not considered to be a significant threat in this evaluation.

The contaminant concentration data will be used to estimate contaminant inventories and to evaluate off-site risk due to mobilized of sediments during floods. The data also will be used in the ecological risk assessment and in certain maintenance activities. Sediments from at least two weir pools (WOCWEIR and MBWEIR) must be removed and stored to return the weir structures into proper configuration for discharge monitoring.

\subsection{EROSION}

\subsubsection{Stream Bank and Channel Erosion}

Techniques for measuring stream bank and channel erosion primarily assess changes in channel form over time. A study of bank and channel erosion has been initiated. Eight sites (six at White Oak Creek and two at Melton Branch) above White Oak Lake were selected to study stream erosion (Fig. 4.10). The stream cross sections were initially surveyed in November 1992, and three to four $25-\mathrm{cm}$ metal pins driven into the bank judged to have the highest erosion rate. The pins were positioned in a line from the baseflow water level to a height about $90 \mathrm{~cm}$ above the water level. After major storms (April 1993, and twice during February 1994), each cross section was resurveyed, and the depth of erosion was determined around the pins.

Based on measurements at erosion pins, the average erosion depth (minimum, mean, and maximum) are presented for sites along White Oak Creek in Fig. 4.11. The largest erosion depths occur on sites with the deepest channel (EP-2,5,6,and 8). Despite the scatter in the data, a trend of increasing average erosion from the 7500 Bridge down to White Oak Lake where the rate decreases due to decreased water velocity is observed. The largest rates of erosion occurred upstream and downstream of the Intermediate Pond area at sites EP-5 and EP-6. At these sites, the average erosion rate was about $10 \mathrm{~cm}$ during 14 months or about $3.3 \mathrm{~cm} / \mathrm{storm}$. No measurement sites were located directly at the Intermediate Holding Pond stream bank due to the radiation hazard to workers, nevertheless the data suggest that the Intermediate Holding Pond may be susceptible to high rates of bank erosion. These data will be used to generate stream-bank erosion rates needed by the computer simulation model for the analysis of sediment transport.

\subsubsection{Soil Erosion}

Erosion studies have been implemented to quantify soil loss in the landscapes found on the Oak Ridge Reservation These methods rely on measurements of radiocesium $\left({ }^{137} \mathrm{Cs}\right)$ that have been globally distributed due to radioactive fallout caused by bomb testing. Cesium-137 levels for these studies are extremely small relative to ${ }^{137} \mathrm{Cs}$ contamination levels in the White 


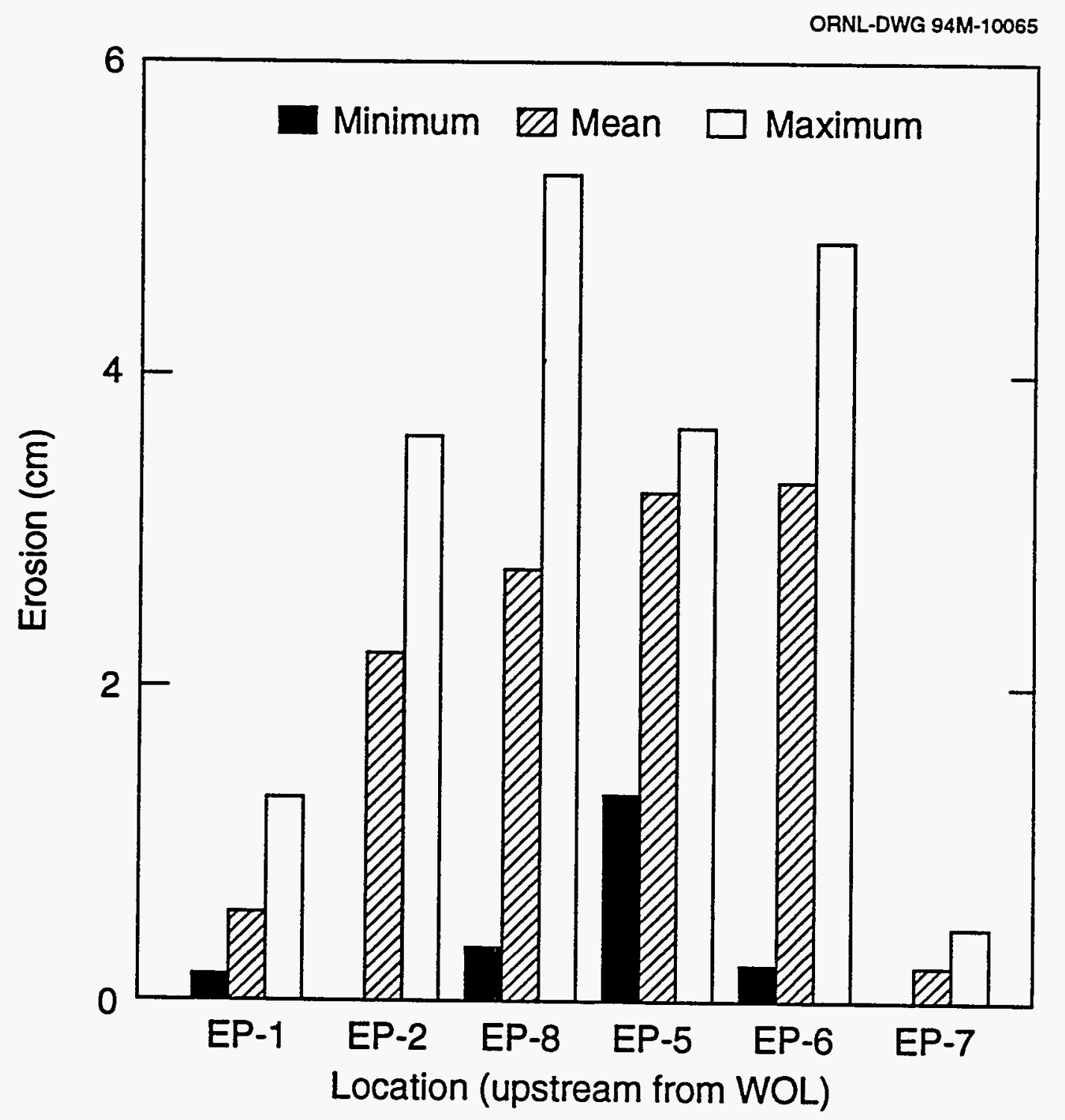

Fig. 4.11. Stream bank erosion measured at sites along White Oak Creek over a 14-month period. 
Oak Creek soils and sediments.

These studies benefit the ER Program by determining the erosion and sediment yield that may result in filling White Oak Lake, thereby reducing its ability in the future to trap both sediments and associated contaminants that might otherwise be retained. Erosion rates are also needed in computer simulation of the sediment transport.

In the past, many researchers have estimated erosion rates using ${ }^{137} \mathrm{Cs}$ redistribution on various landscapes. The ${ }^{137} \mathrm{Cs}$ that reaches the soil surface from fallout is rapidly and tightly adsorbed to soil particles, primarily in the clay and organic fractions and is not readily leached. Erosion transports soil particles and physically redistributes substantial amounts of ${ }^{137} \mathrm{Cs}$. Most studies using the redistributed ${ }^{137} \mathrm{Cs}$ to estimate soil erosion rates have been conducted in open watershed landscapes, which have the potential for loss of ${ }^{137} \mathrm{Cs}$ bonded to suspended clay particles and subsequently, the potential for imprecise erosion rate estimates. The sinkholes with stable side slopes act as natural traps for sediments that fill the basin floors. These sinkholes provide a closed system for measuring ${ }^{137} \mathrm{Cs}$ redistribution, with no significant loss of ${ }^{137} \mathrm{Cs}$. Using sinkholes on three different vegetative systems (crop, grass, and forest) allows for comparing the ${ }^{137} \mathrm{Cs}$ redistribution and soil movement among land use systems. This study aimed to (1) calculate erosion rates in sinkholes under three different land use systems using ${ }^{137} \mathrm{Cs}$ redistribution and (2) compare the erosion rates between land use systems.

Cesium-137 activity was measured from soil cores taken in grid formations over the entire enclosed area of the sinkholes and on the upland areas bordering the sinkholes. A background or baseline activity of ${ }^{137} \mathrm{Cs}$ was measured from an uneroded forest site $\left(3366 \mathrm{~Bq} \mathrm{~m}^{-2}\right.$ or $9.08810^{4} \mathrm{pCi} \mathrm{m}^{-2}$ ). This baseline activity served to gage the redistribution of ${ }^{137} \mathrm{Cs}$. Site activity above the baseline activity indicated soil deposition; site activity less than the baseline indicated soil erosion. This redistribution of ${ }^{137} \mathrm{Cs}$ is combined with a mass balance equation to calculate soil erosion.

The ${ }^{137} \mathrm{Cs}$ was redistributed the most at the cropland, followed by the grassland, and then the forest. The soil erosion rate was greatest in the grassland, followed by the cropland, and then the forest (Table 4.5). The cropland did not show the highest erosion rate even though it had the greatest ${ }^{137} \mathrm{Cs}$ redistribution, because the sinkhole was partially open, thereby leaving an exit for unaccountable ${ }^{137} \mathrm{Cs}$. The forest erosion rate is high. These high erosion rates come from using the ${ }^{137} \mathrm{Cs}$ technique, which collectively records soil redistribution over the last 38 years. During this period, the forest was first denuded for cultivation and erosion rates were extremely high. The Revised Universal Soil Loss Equation shows lower erosion rates, exhibiting soil redistribution at the present time in which the sinkholes have become stable.

Tracing soil movement within sinkhole systems using ${ }^{137} \mathrm{Cs}$ has yieided erosion rates that potentially apply to a broad range of land use types and geographic landscapes. On the Oak Ridge Reservation radiocesium as a soil tracer can be used to predict the rate of sheet erosion in the watersheds of waste sites. This technique can also estimate the total sediment input into an area from ${ }^{137} \mathrm{Cs}$ contaminated soils by subtracting the background ${ }^{137} \mathrm{Cs}$, or noncontaminating portion, from the total input to the system.

To assess if the erosion rates determined by the radiocesium method are reasonable, the rates were compared with a rough estimate of the long-term erosion rate for the White Oak Creek watershed. A lower bound to that estimate can be calculated from the volume of 
deposited sediments in White Oak Lake. Cox et al. (1991) surveyed the bottom of White Oak Lake in 1988 and compared the results with a survey completed in 1944. The results showed that $50 \%$ of the original volume of the lake had been filled with sediments during the intervening 44 years.

Table 4.5. Areas and erosion rates for different land use systems

\begin{tabular}{lcccc}
\hline Site & $\begin{array}{c}\text { Total } \\
\text { area }\end{array}$ & $\begin{array}{c}\text { Depositional } \\
\text { area }\end{array}$ & $\begin{array}{c}\text { Erosion rate } \\
{ }^{137} \mathrm{Cs}\end{array}$ & $\begin{array}{c}\text { Erosion rate } \\
\text { RUSLE }^{a}\end{array}$ \\
\hline Crop & $\mathrm{m}^{2}$ & $\mathrm{~m}^{2}$ & $\mathrm{t} \mathrm{ha}^{-1} \mathrm{yr}^{-1}$ & $\mathrm{t} \mathrm{ha}^{-1} \mathrm{yr}^{-1}$ \\
Grass & 43,000 & 38,883 & 4.2 & 2.6 \\
Forest & 2,975 & 1,419 & 6.5 & 0.6 \\
\hline
\end{tabular}

${ }^{a}$ RUSLE $=$ Revised Universal Soil Loss Equation.

The mass of the sediment that has accumulated in the lake is calculated by assuming a bulk density of $1.5 \mathrm{~g} / \mathrm{cm}^{3}$. Assuming that erosion has been uniform across the watershed the long-term average erosion rate is estimated to be $0.92 \mathrm{tha}^{-1} \mathrm{yr}^{-1}$. This rate is about half of the $2.0 \mathrm{t} \mathrm{ha}^{-1} \mathrm{yr}^{-1}$ for forested areas determined by the radiocesium method. Assuming the watershed has been mostly forested since the beginning of ORNL then the sediment retention rate for White Oak Lake is $50 \%$, which is within the range of $46 \%$ (23MAR93 storm) and 77\% (04DEC93 storm). Because this assumed retention rate seems reasonable the erosion rate of $2.0 \mathrm{t} \mathrm{ha}^{-1} \mathrm{yr}^{-1}\left(0.89\right.$ short tons $\left.\mathrm{acre}^{-1} \mathrm{yr}^{-1}\right)$ appears to be a reasonable preliminary estimate of the long-term erosion rate. Of course, erosion rates are affected by many factors (e.g., slope, slope length); and the land cover at ORNL has always included bare soil and grassland in addition to forest, so that the erosion rate may have been higher and the sediment retention rate correspondingly lower. In any case, this erosion rate provides a reasonable target for initial calibration of the Hydrologic Simulation Program-Fortran model.

\subsection{SUMMARY}

The data collection activities of the Soil and Sediment Task are designed to address the major components of the sediment transport conceptual model. Sediment transport sampling during floods provides a watershed-wide picture of the movement of suspended sediment and particle-bound ${ }^{137} \mathrm{Cs}$. The storm of December 1993 had an estimated return period of 5 years, and these data were summarized in this section. Additional data have been collected for three storms in early 1994, all roughly 5-year storms, but data analysis is incomplete.

At this point interpretation of the storm sampling results is not straightforward. The data suggest that the weir pools behind the major weirs WOCWEIR and MBWEIR continue to accumulate sediments even though they appear to be nearly filled with sediments from past floods. The larger December 1993 storm deposited more sediments in the White Oak Creek 
floodplain and White Oak Lake than did the 2-year storm of March 1993. The December storm generated less off-site discharge of ${ }^{137} \mathrm{Cs}$ (approximately 0.027 compared with $0.044 \mathrm{Ci}$ ). This difference in sediment transport between storms of differing magnitude may be explained as the data from the 1994 storms 17 are analyzed and when the Hydrologic Simulation Program-Fortran model is fully implemented. Grain-size distributions of samples collected during the December storm indicate that in the weir pools and White Oak Lake larger particles tend to settle out and deposit rather than the smaller-sized particles, as expected.

The walk-over radiation survey reported in ERMA (1993) was used to guide the initial floodplain sampling. The results from the walk-over data indicate that gamma radiation on the floodplain decreases in the direction away from White Oak Creek, presumably due to decreased deposition of ${ }^{137} \mathrm{Cs}$-laden sediments. The initial soil coring data confirmed this trend. More sampling will be conducted with the purposes of identifying other contaminants in addition to ${ }^{137} \mathrm{Cs}$ and to update the inventories of ${ }^{137} \mathrm{Cs}$ in the WAG 2 sources identified in the sediment transport conceptual model.

The sources and rates of erosion of both contaminated and clean sediments are important to the characterization of WAG 2 and to the issues of sediment transport. Contaminated sediments are transported to secondary sources such as the weir pools and the bottom of White Oak Lake where they can be transported off-site during extreme storms. Clean sediments tend to become contaminated as they mix with contaminated sediments. All sediments fill the weir pools and White Oak Lake decreasing their retentive capacities and confounding hydrologic measurements.

Stream bank erosion data have been collected and a preliminary analysis shows a trend of increasing bank erosion along White Oak Creek until the creek enters the wide floodplain area above White Oak Lake. The average erosion rate for sites near the Intermediate Holding Pond is $3.3 \mathrm{~cm}$ per major storm. Further work is needed to know how to use these measurements to generate watershed-wide estimates. In a supporting study of hillslope erosion, a method for direct measurement of long-term erosion rates was investigated. For forested watersheds in the vicinity of the White Oak Creek basin, the preliminary estimate of long-term erosion is $2.0 \mathrm{t} \mathrm{ha}^{-1} \mathrm{yr}^{-1}\left(0.89\right.$ short tons acre $\left.\mathrm{yr}^{-1}\right)$, which appears reasonable for the basin itself assuming a $50 \%$ sediment retention rate in White Oak Creek drainage system. This estimate of the erosion rate will assist in computer model parameterization.

Data collected in this task will be used to implement the Hydrologic Simulation ProgramFortran (HSPF) model. In turn, the calibrated model will be used to predict the watershed response to conditions that cannot be directly observed. Furthermore, these data provide insight into how contaminants are actually being transported. The computer assessments will be beneficial for the design of remedial projects for source WAGs and WAG 2, itself. Data collection, modeling and integration of the results into ER planning ensure that no remedial design will inadvertently cause excessive scour and erosion of contaminated soil and sediment in WAG 2 that could, in turn, lead to increased risks or harmful exposures to the public. 


\section{BIOTA}

T. L. Ashwood, S. M. Adams, B. G. Blaylock, C. A. Branson, D. K. Cox, M. S. Greeley, W. R. Hill, R. L. Hinzman, J. M. Loar, B. R. O'Neal, M. J. Peterson, E. M. Schilling, J. G. Smith, G. R. Southworth, and A. J. Stewart

\subsection{INTRODUCTION}

In response to a condition of the National Pollutant Discharge Elimination System permit issued to ORNL on April 1, 1986, a Biological Monitoring and Abatement Program was developed in 1986 for White Oak Creek; selected tributaries of White Oak Creek, including Fifth Creek, First Creek, Melton Branch, and Northwest Tributary; and the Clinch River (Loar 1991). The Biological Monitoring and Abatement Program currently consists of six major tasks that address both radiological and nonradiological contaminants in the aquatic and terrestrial environs on site and off site. These tasks are: (1) toxicity monitoring, (2) bioaccumulation monitoring of nonradiological contaminants in aquatic biota, (3) biological indicator studies, (4) instream ecological monitoring, (5) assessment of contaminants in the terrestrial environment, and (6) radioecology of White Oak Creek and White Oak Lake.

The Biological Monitoring and Abatement Program was developed to meet three objectives. First, studies (tasks) were designed to provide sufficient data to determine whether the effluent limits established for ORNL protect and maintain the classified uses of White Oak Creek, Melton Branch, Northwest Tributary, First Creek, and Fifth Creek. These streams have been classified by the Tennessee Department of Environment and Conservation for (1) growth and propagation of fish and aquatic life, (2) irrigation, and (3) livestock watering and wildlife (EPA 1986).

Second, the Biological Monitoring and Abatement Program will provide ecological characterizations of White Oak Creek and tributaries and of White Oak Lake that can be used to (1) document ecological impacts of past and current operations and (2) identify contaminant sources that adversely affect stream biota. This ecological information has been important in the development of various Remedial Investigation/ Feasibility Study plans and reports and in the assessment of remedial action alternatives within the ORNL ER Program.

Third, the Biological Monitoring and Abatement Program will document the effects on stream biota from implementation of the ORNL ER Program and the Water Pollution Control Program. The ecological characterization of White Oak Creek watershed has provided baseline data that can be used to document the ecological effects of the Water Pollution Control Program and the ORNL ER Program and to determine the success of remedial actions implemented under these programs. The long-term nature of the Biological Monitoring and Abatement Program ensures that the effectiveness of remedial measures will be properly evaluated.

Agreements reached at the beginning of the ORNL Biological Monitoring and Abatement Program led to funding of certain portions of the Biological Monitoring and Abatement Program by the ER Program because data from the Biological Monitoring and 
Abatement Program would be used to (1) characterize the extent of contamination from source operable units to biotic receptors, (2) assess the ecological risk of contamination from source operable units, and (3) monitor the effectiveness of remedial actions. Tasks funded in part by the ER Program include toxicity monitoring, biological indicator studies, and instream ecological monitoring. The assessment of contaminants in terrestrial biota and radioecology of White Oak Lake are funded entirely by the ER Program.

An annual report is produced as part of the ORNL Biological Monitoring and Abatement Program. The following sections, which are organized by task, present summaries of the annual report for 1993 (Ashwood 1994). Also included, in Sect. 5.3.2, is a summary of the results to date of the Ecological Assessment task.

\subsection{TOXICITY MONITORING}

The toxicity monitoring task established under ORNL's Biological Monitoring and Abatement Program has two goals: (1) identify sources of toxicity to streams in the White Oak Creek watershed, and (2) monitor toxicity of water in White Oak Creek and its tributaries and, in the process, assess the usefulness of the toxicity test systems for detecting and quantifying ambient toxicity. Various special studies are sometimes conducted, on an ad hoc basis, to assess specific relationships between ambient toxicity, water quality, and processes affecting energy and contaminant flow into primary consumers in streams within the White Oak Creek watershed.

Since the Biological Monitoring and Abatement Program's inception in March 1986, water from 15 sites on five streams (Fig. 5.1) has been evaluated for toxicity at least 35 times. Several of these sites have been tested more frequently. The results of these tests and their attendant chemical analyses have generated a core data set that is used to provide a "broad brush" understanding of ambient toxicity in streams at ORNL. Four of the 15 sites (upstream sites on First Creek, Fifth Creek, White Oak Creek, and Melton Branch; Fig. 5.1) are presumed to lack contaminants in toxic concentrations and are used as reference sites. The remaining 11 sites are potentially affected by contaminants from the ORNL main plant area or from downstream sources on White Oak Creek. Two of these 11 sites (WCK 2.65 and MEK 0.16; Fig. 5.1) are part of the Toxicity Control and Monitoring Program portion of ORNL's NPDES permit.

Point- and area-source contributions to ambient toxicity in streams at ORNL were evaluated using standard EPA protocols for 7-d static-renewal chronic toxicity tests based on the survival and growth of fathead minnow (Pimephales promelas) larvae, and the survival and reproduction of a daphnid (Ceriodaphnia dubia).

For the second consecutive year, ambient toxicity tests conducted in 1993 revealed no evidence of acute or chronic toxicity at any of the 15 locations.

During the 1993 reporting period, water and foam samples from five streams near ORNL (White Oak Creek, East Fork Poplar Creek, Bear Creek, Ish Creek, and Mitchell Branch) were analyzed for lipid content, lipid-class composition and PCBs. This study was conducted to better understand the source of patches of foams on streams; foams, scums and sheens are considered to be phenomena of possible concern in the Friends of the Earth settlement with the DOE. 


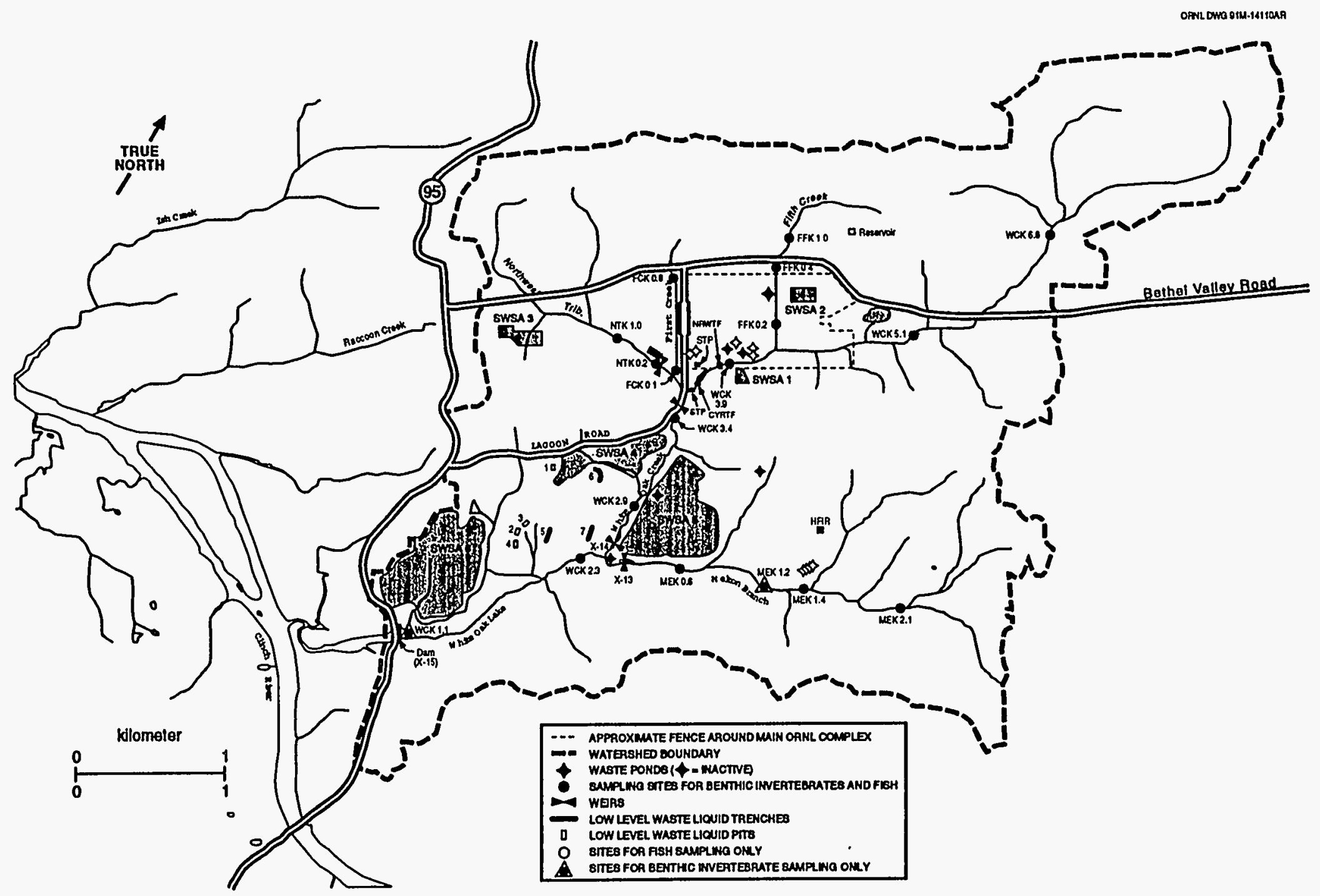

Fig. 5.1. Location of liquid and solid radioactive waste disposal/storage areas: National Pollutant Discharge Elimination System monitoring sites on Melton Branch (X13), White Oak Creek (X14), and White Oak Dam (X15); and sampling sites for benthic invertebrates and fish in White Oak Creek watershed. FCK $=$ First Creek kilometer, FFK $=$ Fifth Creek kilometer, HFIR $=$ High Flux Isotope Reactor, MEK = Melton Branch kilometer, STP = Sewage Treatment Plant, SWSA = solid radioactive waste storage area, WCK = White Oak Creek kilometer, NTK = Northwest Tributary kilometer. 
Analyses of stream water and foam showed much variation in the concentration of lipids. Lipid contents in stream waters ranged from below detection to $1.5 \mathrm{mg} / \mathrm{L}$. The concentration of lipids in the foams also varied, but was always greater than in the subsurface water. Although concentrations of lipids in foams typically ranged from 10 to $50 \mathrm{mg} / \mathrm{L}$, concentrations of $110 \mathrm{mg} / \mathrm{L}$ were found in White Oak Creek.

Foams in lower White Oak Creek and Bear Creek contained hydrocarbons at levels that suggest contamination by petroleum products. Concentration of petroleum hydrocarbons in foams makes their detection possible even when oil concentrations in the underlying stream water are below detection levels.

Stream foams were also enriched in PCBs with respect to concentrations in the subsurface waters. Concentrations of PCBs in stream subsurface waters ranged from $0.069 \mathrm{ppb}$ in White Oak Creek, to approximately $0.11 \mathrm{ppb}$ in the other streams. However, concentrations of PCBs in foams ranged from $0.534 \mathrm{ppb}$ in Northwest Tributary to $1.008 \mathrm{ppb}$ in Mitchell Branch.

\subsection{BIOACCUMULATION STUDIES}

\subsubsection{Aquatic System}

The aquatic bioaccumulation monitoring task has five subtasks with the following objectives: (1) to determine what materials present in the White Oak Creek system accumulate to unacceptable levels in aquatic biota, (2) to identify specific sources of any observed contamination, (3) to calibrate water quality monitoring data against contaminant levels in biota, (4) to determine the source and scope of PCB contamination of channel catfish in the White Oak Creek embayment and the Clinch River, and (5) to assist development of the capability to forecast future levels of biotic contamination under various remedial action alternatives.

Up to 12 sunfish were collected by electrofishing at each of three sites on White Oak Creek (WCK 2.3, 2.9, and 3.5) and at single sites on White Oak Lake, White Oak Creek embayment, Northwest Tributary, and Melton Branch in winter 1992/1993. Fish fillets were analyzed for mercury and other trace metals and for PCBs. Asiatic clams were placed at various sites in White Oak Creek, White Oak Lake, and Melton Branch to monitor for organic contaminants.

Mercury and PCB results from fish studies are summarized in Figs. 5.2 and 5.3. These figures also present results from similar studies at other sites on the Oak Ridge Reservation. All values in ORNL streams were below action levels established by the U.S. Food and Drug Administration. However, fish from sites closest to the ORNL main plant area contain mercury and PCBs at concentrations greater than fish from an uncontaminated reference site.

Mercury concentrations in White Oak Creek fish are generally much lower than in fish from other contaminated streams on the Reservation (Fig. 5.2). Furthermore, the average mercury concentration in bluegill from the Clinch River just downstream from White Oak Creek was not significantly higher than the average concentration in sunfish upstream of White Oak Creek (Fig. 5.2). Thus, mercury contamination in the White Oak Creek drainage 


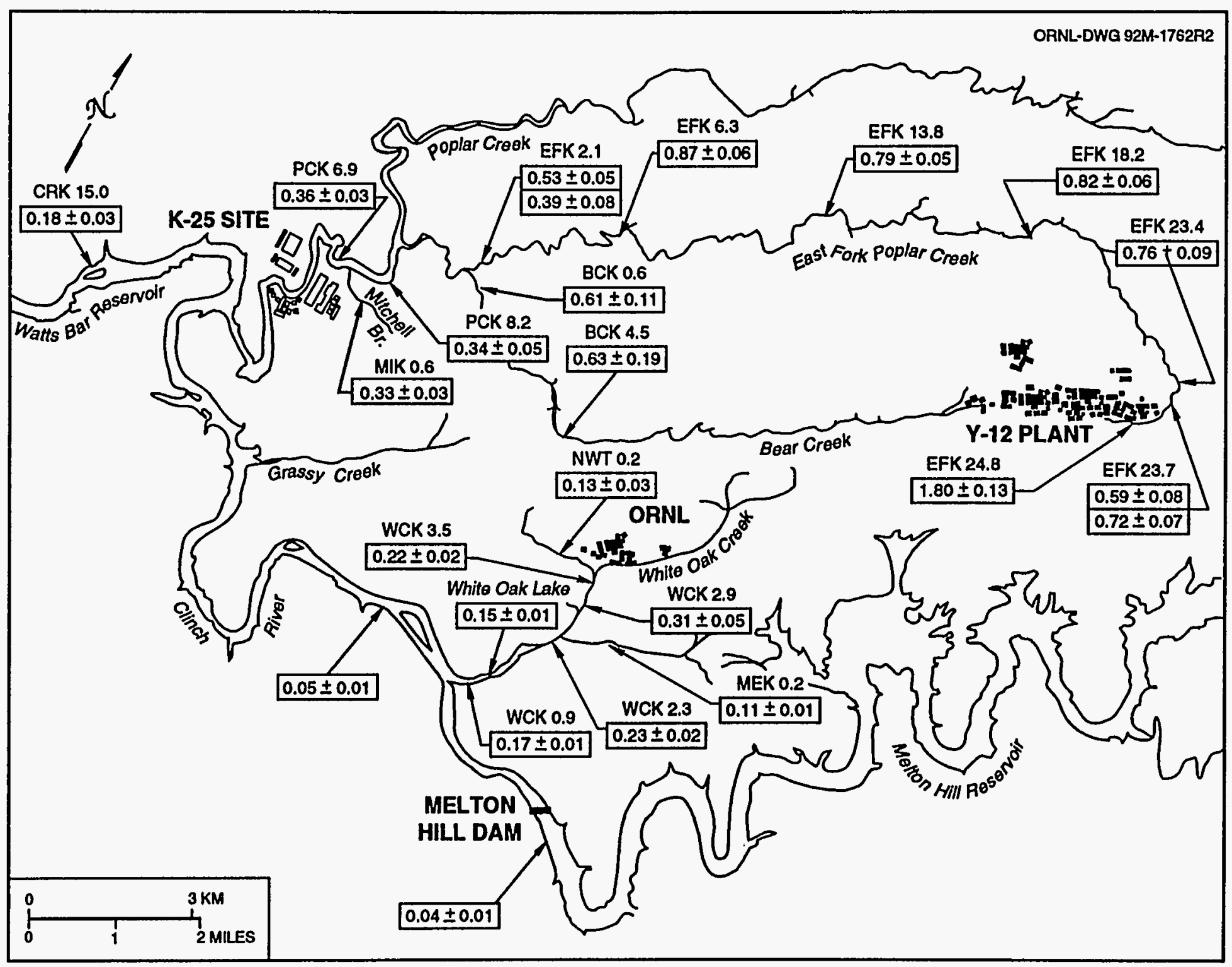

Fig. 5.2. Average concentrations ( $\pm 1 \mathrm{SE})$ of mercury $(\mu \mathrm{g} / \mathrm{g}$, wet $w t)$ in sunfish collected ( $\mathrm{n}=8$ fish per site) from November 1992 to March 1993 at sites on the Oak Ridge Reservation. 


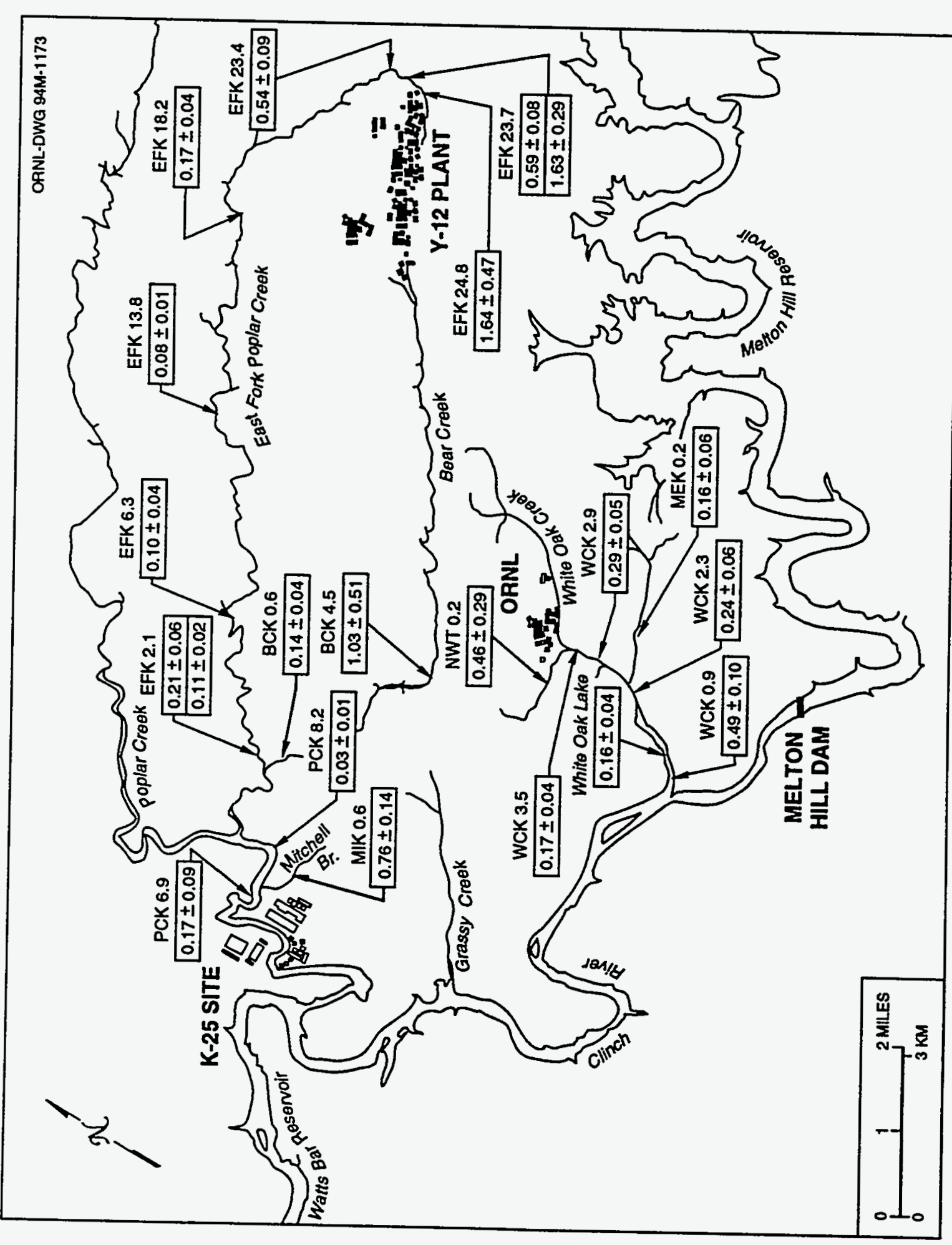

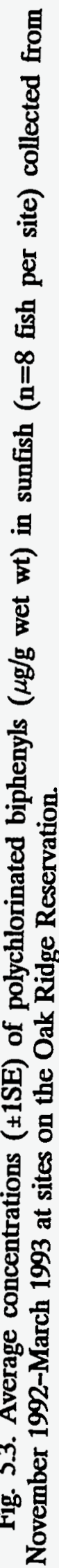


in 1992/1993 continues to have no discernible effect on mercury concentrations in the Clinch River.

PCB concentrations in White Oak Creek sunfish appear to have exhibited a decreasing trend since 1987. Linear regression of PCB concentrations in sunfish versus time indicated a significant decrease over the 1987-1993 period at WCK 3.5, 2.9, 2.3, and White Oak Lake.

Chlordane and PCBs were detected in several clam samples, but all reported concentrations, with the exception of PCBs from White Oak Lake, were below the range of reliable quantification. Although PCB concentrations in clams in 1993 were lower than previously reported, they continued to be detected at sites where PCB accumulation in clams was evident in the past. The site-to-site pattern of chlordane in upper White Oak Creek is similar to that in previous years. It is believed that the chlordane is from an episodic release that occurred near WCK 5.4 in the late 1980 s.

Channel catfish (Ictalurus punctatus) were collected in White Oak Creek embayment and lower Poplar Creek as well as at sites on the Clinch River in Melton Hill Reservoir, $1.3 \mathrm{~km}$ below the mouth of White Oak Creek, and $4 \mathrm{~km}$ below the mouth of Poplar Creek. The purpose of these samples is to evaluate the relative contributions of White Oak Creek and Poplar Creek to PCB contamination in Clinch River fish. PCB contamination was found at all sites, including Melton Hill Reservoir. The highest concentrations $(8.4 \mu \mathrm{g} / \mathrm{g}$ ) were found in White Oak Creek embayment fish, all of which exceeded the FDA action level of $2 \mu \mathrm{g} / \mathrm{g}$. This site has had the highest mean PCB concentrations in seven of the past eight years.

Results of the 1993 PCB monitoring of channel catfish are consistent with the pattern seen in previous years; some channel catfish in the Clinch River near White Oak Creek are likely to contain elevated PCB concentrations, and a significant fraction of the PCB content of those fish originates in the White Oak Creek drainage. However, with the construction of a sediment retention structure in 1991, the likelihood of fish moving into White Oak Creek embayment, accumulating a high concentration of PCBs, and then moving back into the Clinch River has probably decreased significantly.

\subsubsection{Terrestrial System}

Since 1991, the terrestrial component of Biological Monitoring and Abatement Program focused primarily on collection and analysis of raccoon (Procyon lotor) fur samples. As part of the remedial investigation of WAG 2, the feasibility of monitoring belted kingfishers (Ceryle alcyon) and mink (Mustela vison) is being assessed. Each of these activities is summarized below.

\subsubsection{Raccoon Monitoring}

Raccoons consume a wide variety of prey and vegetation, some from aquatic systems. Studies throughout North America have demonstrated the potential for raccoons to serve as indicator species for a wide range of contaminants including: heavy metals, PCBs and organochlorine pesticides, and radionuclides. Based on this evidence, a long-term monitoring program was initiated using raccoons as ecological indicators of biologically available contamination (especially mercury and ${ }^{137} \mathrm{Cs}$ ) in the terrestrial ecosystem. This report presents data from the 1993 annual monitoring of raccoons in White Oak Creek and reference areas. 
Raccoons were collected from the White Oak Creek and Melton Branch floodplains using live traps baited with sardines or cat food. After capture, raccoons were sedated with Ketaset, and samples of fur and adipose tissue were taken. Fur samples were analyzed for gamma-emitting radioisotopes and trace metals. Adipose samples were analyzed for PCBs and organochlorine pesticides. Results from metals and PCB analyses were not available at the time this report was prepared.

For the third year, some raccoons from the White Oak Creek area were contaminated with ${ }^{60} \mathrm{Co}$ and ${ }^{137} \mathrm{Cs}$. Reference site raccoons do not have detectable concentrations of these radionuclides $\left(<0.5 \mathrm{pCi} / \mathrm{g}\right.$ ) in their fur. In $1993,17.6 \%$ of the raccoons contained ${ }^{60} \mathrm{Co}$ at concentrations higher than $1 \mathrm{pCi} / \mathrm{g}$ (max.: $1.63 \mathrm{pCi} / \mathrm{g}$ ), and $11.8 \%$ of the raccoons contained ${ }^{137} \mathrm{Cs}$ at concentrations higher than $1 \mathrm{pCi} / \mathrm{g}$ (max.: $2.23 \mathrm{pCi} / \mathrm{g}$ ). The proportion of raccoons contaminated with ${ }^{60} \mathrm{Co}$ is similar to the level in 1992, but the proportion of 1993 raccoons contaminated with ${ }^{137} \mathrm{Cs}$ is substantially lower. Differences in food sources utilized by the raccoons between years is the most likely cause of these year-to-year fluctuations.

\subsubsection{Kingfisher Monitoring}

The belted kingfisher is a piscivorous and territorial avian species that may be a suitable indicator of contaminant accumulation at specific sites on the Oak Ridge Reservation. Kingfishers have been sighted frequently, feeding from most Oak Ridge Reservation waterways, and they are likely to be exposed to contamination present in fish from those streams because they consume fish and crayfish at a rate of $50 \%$ of their body weight per day.

As part of the biota studies component of the WAG 2 remedial investigation, an investigation into the efficacy of using the kingfisher as an ecological indicator of aquatic contaminants on the Oak Ridge Reservation was initiated in late August 1992. The primary objective of this study was to acquire information concerning the ecology of the kingfisher to determine how the species could be used within the framework of the Biological Monitoring and Abatement Program at ORNL. A second important objective of the study was to assess the feasibility of monitoring contaminant levels in kingfishers. If such measurements are possible, a third objective of the investigation is to determine the extent to which Oak Ridge Reservation kingfishers are contaminated.

In 1993, work was supposed to include surveying of kingfisher burrows with a special probe to be developed for that purpose. Completion of the probe was delayed until early 1994, so no burrow surveys were conducted in 1993. However, three kingfisher carcasses were recovered from different areas of the Oak Ridge Reservation. These carcasses were necropsied, and samples were sent to an outside analytical lab for trace metals analyses.

The kingfisher carcasses were found in three very different locations on the Oak Ridge Reservation (Table 5.1). The kingfisher found near Lake Reality was actually floating in a concrete tank and appeared to have been killed during a tornado or severe thunderstorm that passed through the area a day before the find. The second bird was observed by health physics technicians who were working south of Bldg. 4505, ORNL. The bird attacked the technicians twice and then fluttered to the ground where it died. The third bird was a probable roadkill found along the side of Highway 95 near where a reach of East Fork Poplar Creek parallels the road. 
Table 5.1. Radionuclide and trace metal concentrations in various kingfisher samples from the Oak Ridge Reservation

\begin{tabular}{|c|c|c|c|c|c|c|c|}
\hline $\begin{array}{c}\text { Sample } \\
\text { No. }^{\mathrm{a}}\end{array}$ & Location/Date & $\begin{array}{l}{ }^{137} \mathrm{Cs} \\
(\mathrm{pCi} / \mathrm{g})\end{array}$ & $\underset{(\mathrm{mg} / \mathrm{kg})}{\mathrm{As}}$ & $\underset{(\mathrm{mg} / \mathrm{kg})}{\mathrm{Cd}}$ & $\underset{(\mathrm{mg} / \mathrm{kg})}{\mathrm{Hg}}$ & $\begin{array}{c}\mathrm{Pb} \\
(\mathrm{mg} / \mathrm{kg})\end{array}$ & $\begin{array}{c}\mathrm{Se} \\
(\mathrm{mg} / \mathrm{kg})\end{array}$ \\
\hline $001 \mathrm{~KB}$ & Lake Reality ${ }^{b} /$ & $<2$ & & & & & \\
\hline 001KF & $22 \mathrm{Feb} 93$ & & $<0.40$ & $<0.20$ & 13.9 & 2.67 & 5.38 \\
\hline $001 \mathrm{KH}$ & & & $<0.40$ & $<0.20$ & 1.1 & $<0.40$ & 1.25 \\
\hline $001 \mathrm{KK}$ & & & $<0.40$ & 4.04 & 8.65 & $<0.40$ & 5.81 \\
\hline $001 \mathrm{KL}$ & & & $<0.40$ & 0.95 & 3.69 & $<0.40$ & 2.71 \\
\hline $001 \mathrm{KM}$ & & & $<0.40$ & $<0.20$ & 0.57 & $<0.40$ & $<0.40$ \\
\hline $002 \mathrm{~KB}$ & Bldg. $4505^{c}$ & 13,690 & & & & & \\
\hline $002 \mathrm{KF}$ & $18 \mathrm{Mar} 93$ & & $<0.40$ & 0.34 & 2.72 & 4.88 & 7.29 \\
\hline $002 \mathrm{KH}$ & & 81 & $<0.40$ & $<0.20$ & 9.52 & $<0.40$ & 2.2 \\
\hline $002 \mathrm{KK}$ & & 69 & $<0.40$ & 1.53 & 26.8 & 0.42 & 6.01 \\
\hline $002 \mathrm{KL}$ & & 76 & $<0.40$ & 0.90 & 17.6 & $<0.40$ & 7.5 \\
\hline $002 \mathrm{KM}$ & & 151 & $<0.40$ & $<0.20$ & 6.34 & 0.58 & 1.84 \\
\hline $003 \mathrm{KF}$ & EFPC / & & $<0.40$ & 7.21 & 4.55 & 1.86 & 5.63 \\
\hline $003 \mathrm{KH}$ & 19Jul93 & & $<0.40$ & $<0.20$ & 0.59 & $<0.40$ & 2.01 \\
\hline $003 \mathrm{KK}$ & & & $<0.40$ & 0.40 & 1.46 & $<0.40$ & 3.14 \\
\hline $003 \mathrm{KL}$ & & & $<0.40$ & 0.23 & 0.96 & $<0.40$ & 3.45 \\
\hline $003 \mathrm{KM}$ & & 3 & $<0.40$ & $<0.20$ & 0.81 & $<0.40$ & 1.04 \\
\hline
\end{tabular}

${ }^{\mathrm{a}} \mathrm{KB}=$ whole body; $\mathrm{KF}=$ feathers; $\mathrm{KH}=$ heart; $\mathrm{KK}=$ kidney; $\mathrm{KL}=$ liver; $\mathrm{KM}=$ muscle.

'Bird was found floating in an open concrete tank of water near Lake Reality at the Y-12 Plant. 'Bird was found south of Bldg. 4505 at Oak Ridge National Laboratory.

${ }^{\mathrm{d} B i r d}$ was found on roadside of Highway 95 adjacent to a reach of East Fork Polar Creek. 
There is no background information on trace metal concentrations in kingfishers. Nevertheless, it is surprising that all three birds contained measurable levels of cadmium and mercury in their internal organs. Mercury concentrations were highest in the bird found at 4505. Cesium-137 concentrations in this bird were so high that it had almost certainly been feeding in White Oak Creek watershed, possibly in one of the radioactive ponds on the ORNL site. The behavioral abnormality observed in this bird just before its death is consistent with heavy metal toxicity suggested by the high concentrations of mercury in the liver and kidney. Cadmium concentrations were highest in the bird from Lake Reality. The presence of cadmium in all three animals suggests that more attention needs to be paid to this contaminant in future monitoring and risk assessment efforts.

It appears from these limited data that feathers are an excellent tissue in which to monitor $\mathrm{Cd}, \mathrm{Hg}, \mathrm{Pb}$, and $\mathrm{Se}$. In some cases, the kidney may be a more sensitive indicator of $\mathrm{Cd}$ and $\mathrm{Hg}$ contamination, but kidney samples cannot be obtained in a nondestructive manner.

\subsubsection{Mink monitoring}

Mink also feed extensively on aquatic biota, though they also feed on small mammals not associated with streams. Mink are highly sensitive to mercury and PCB contamination, and one modeling study of the Oak Ridge Reservation mink population suggests that some individuals may be at risk for adverse reproductive effects (MacIntosh et al. 1993). Mink were also studied as part of the biota studies component of the WAG 2 remedial investigation. Objectives of the mink study are (1) to determine if mink from the Oak Ridge Reservation streams are more contaminated with PCBs and mercury than mink from reference areas, (2) to assess, if possible, whether the Oak Ridge Reservation mink population is adversely impacted by such contamination, and (3) to assess the feasibility of monitoring contaminant levels in mink as part of a routine program.

Mink trapping was accomplished by placing small, double-ended cage traps along probable mink pathways and disguising the traps to look like tunnels. No bait was used in the traps, because bait would have attracted nontarget animals such as raccoons and skunks, which are more abundant than mink. This would have actually reduced the probability of catching mink.

Despite 800 trap nights in 1993, only one mink was captured (on East Fork Poplar Creek in the city of Oak Ridge) in early November 1993. This mink was transported to the University of Tennessee Veterinary School, where a radio transmitter was implanted in the abdominal area. Samples of mink fur and adipose tissue were also collected during the implantation surgery. After recovery from the surgery, the mink was released at the location of his capture.

The mink was radio tracked for 2 months following his release. During this period of time, he moved upstream on East Fork Poplar Creek into the Y-12 plant. Most of the mink's time was spent in the vicinity of Lake Reality, but he was found on more than one occasion to be well inside the plant on Upper East Fork Poplar Creek. After late January 1994, we were unable to relocate the mink in any area of the Oak Ridge Reservation, even from the air. 
Four mink roadkills have been collected and sampled for fat and hair. Only one of these roadkills was on the Oak Ridge Reservation (near the Highway 95/Highway 58 interchange). No data on mink contamination is available at report time.

\subsection{BIOLOGICAL INDICATORS OF CONTAMINANT STRESS}

As a representative indicator of the health of the White Oak Creek system, the redbreast sunfish (Lepomis auritus) has been the primary target fish species for this Biological Monitoring and Abatement Program task since 1989. The redbreast sunfish is especially suited for assessing the ecological health of the White Oak Creek system as a result of its relative abundance and position at the top of the food chain in this stream.

Assessing the overall health of the redbreast sunfish population in White Oak Creek involves four principal components: (1) analysis of functional biological response groups (individual response parameters) for fish sampled in 1992, (2) comparison of integrated bioindicator responses between 1989 and 1992, (3) evaluation of reproductive and developmental competence in fish, and (4) population-level analyses. For this report, we will focus on the latter three components because component 2 integrates the results of component 1 and provides a better comparison of overall fish health in White Oak Creek to that in reference sites.

For the fish health assessment (components 1,2, and 4), sampling was conducted during summer 1992 in White Oak Creek between White Oak Creek kilometer (WCK) 2.2 and 2.7 and in three reference streams, including Brushy Fork located between Oliver Springs and Clinton, Hinds Creek between Clinton and Norris, and Paint Rock Creek in Loudon County. At each of these sites, redbreast sunfish of all sizes and age groups were collected by electroshocking. Blood samples were taken from 15-20 of the larger males within 2 min after collection. All fish were processed for the population-level analysis by recording total length and weight and removing a sample of scales for age and growth determination.

For the reproductive competence evaluation (component 3), female redbreast sunfish were sampled from White Oak Creek, Hinds Creek, Brushy Fork, and Paint Rock Creek in May and June 1993 to assess reproductive condition prior to the beginning of the breeding season. Total lengths and weights were recorded for each fish. Following sacrifice of the fish, gonads were removed and weighed. The reproductive competence evaluation also includes a toxicity test involving Medaka (Oryzias latipes) embryos. The test, developed in the Environmental Sciences Division, involves exposure of Medaka embryos to water from various sites.

\subsubsection{Integrated Fish Health (Component 2)}

To evaluate the integrated responses of fish to environmental stress among sites and years, all of the individual bioindicators were analyzed with a discriminant analysis procedure. This integrated approach to evaluating the effects of water quality on a fish population has the primary advantage of providing an integrated assessment of the health of fish based on multiple rather than individual indicators. Two major response patterns were evident from the results of the discriminant analysis (Fig. 5.4): (1) the integrated response of fish in White Oak Creek is always significantly different than in fish from the reference sites, and (2) the response of fish in White Oak Creek is moving closer over time to the response of fish from 


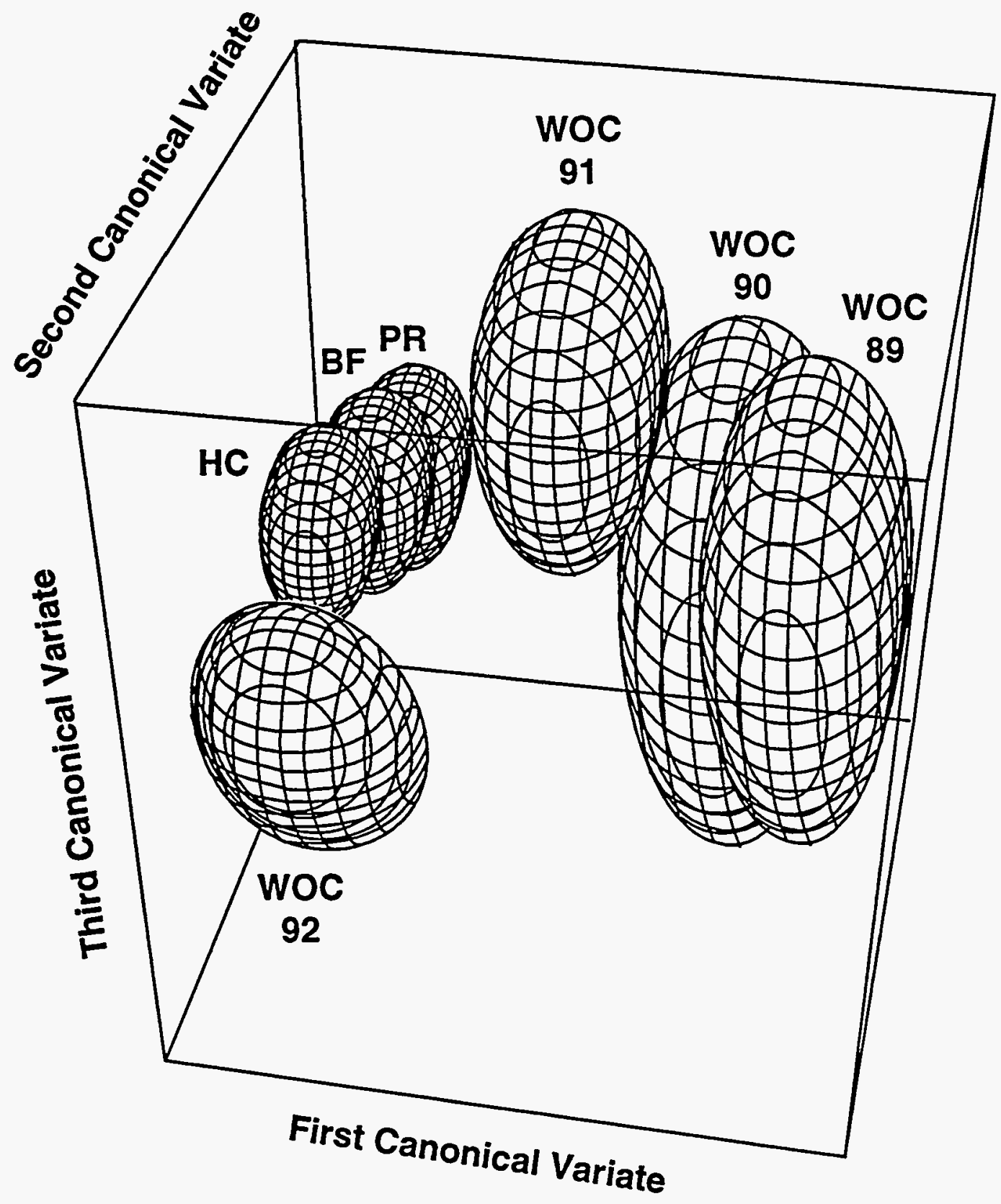

Fig. 5.4. Segregation of integrated health responses for male redbreast sunfish collected from 1989 to 1992 at three reference streams and White Oak Creek (WOC). Ellipsoids for the three reference streams represent the mean integrated response for all four sampling years together. Ellipsoids for WOC are the integrated responses for each year separately. HC $=$ Hinds Creek, $\mathrm{BF}=$ Brushy Fork, and $\mathrm{PR}=$ Paint Rock Creek. 
the reference sites.

\subsubsection{Reproductive and Developmental Competence (Component 3)}

It appears that the overall reproductive condition of redbreast sunfish in White Oak Creek shifted between 1989 and 1993 towards a condition more typical of redbreast sunfish populations in the reference streams. Notwithstanding this apparent improving trend in reproductive competence, there continues to be evidence that some reaches of White Oak Creek are at least intermittently toxic to some fish embryos or larvae. In Medaka embryo/larval toxicity tests, water from White Oak Creek upstream of ORNL (WCK 6.8) proved consistently nontoxic to Medaka embryos. Water from another upstream site within the confines of ORNL (WCK 5.1) had no adverse effect on embryo survival in one trial, but caused significant embryo-mortality in a second trial. Water from lower White Oak Creek (WCK 2.65 and 2.3) and the White Oak Lake outfall proved to be highly toxic to embryos, while intermediately located sites (WCK 4.4, 3.8 and 3.4) produced somewhat more variable results.

The cumulative results of a series of embryo-larval tests conducted since 1991 on water from various sites in the White Oak Creek watershed strongly suggest that a significant source of toxicity to embryos exists between WCK 5.1 and 4.4, and that the toxic effect persists and appears to be amplified throughout the remainder of White Oak Creek and White Oak Lake.

\subsubsection{Population Analysis}

Fish populations in 1992 were characterized by a larger percentage of older fish than were found in previous years. This may have been primarily due to the strength of the 1988 year class across all sites. White Oak Creek also had more 5-year old fish present than in previous years. Fifty-one percent of the fish in White Oak Creek were 4 years of age or older. Normally, populations are composed of higher proportions of 2- and 3-year old fish. For the second consecutive year, a very small number of age 2 fish (less than 5) were collected in White Oak Creek. This number was very low compared to the number of age 2 fish found at the reference sites.

\subsection{INSTREAM ECOLOGICAL MONITORING}

\subsubsection{Periphyton}

Periphyton communities in stream ecosystems are complex assemblages of autotrophs (algae) and heterotrophs (fungi, bacteria, protozoa) that are attached to substrates and often embedded in a polysaccharide matrix. Monitoring of these communities is an important part of the ORNL Biological Monitoring and Abatement Program because they represent a highquality food resource for many lotic invertebrates and herbivorous fishes. Periphyton is also an entry point for contaminants in the food chain (e.g., mercury and cadmium are concentrated within the periphyton matrix). Periphyton communities possess several properties that make them particularly useful in detecting short-term environmental changes: they are ubiquitous, easy to sample, and have short generation times. Consequently, infrequent pulses of toxicants may be easier to detect in periphyton than in longer-lived organisms. 
Previous monitoring and related studies conducted during 1987-1991 resulted in several conclusions about the periphyton communities in White Oak Creek and its tributaries. Slow algal colonization rates, limited algal taxonomic composition, and a patchy periphyton cover suggest that periphyton at sites near ORNL discharges (i.e., WCK 3.9) were experiencing significant stress. Periphyton at WCK 3.9 consisted primarily of a type of unicellular green algae that characteristically occurs where chlorine is present.

Rocks and their associated periphyton were collected from nine sites in the White Oak Creek watershed. Five of the nine sites were downstream from effluents from ORNL facilities (WCK 3.9, 3.4, 2.9, 2.3, and MEK 0.6). The remaining four sites were located upstream from ORNL facilities (WCK 6.8, 5.1, MEK 1.6, and FFK 1.1). Rocks collected from each site were used in biomass (chlorophyll a) and photosynthesis $\left({ }^{14} \mathrm{C}\right.$ uptake) measurements.

As noted in previous reports, diatoms were most common at downstream sites. Assemblages at sites closest to ORNL had relatively large contributions from prostrate green algae. Periphyton at WCK 3.9 was dominated by unicellular prostrate green algae that are commonly found at chlorine-impacted sites.

Severe weather affected seasonal patterns at many sites. The hot, dry summer of 1993 caused MEK 1.6 to dry up for several months, and December floods removed periphyton almost completely at several downstream sites. Annual mean chlorophyll $a$ values were lowest at upstream reference sites WCK 6.8 and MEK 1.6, reflecting grazing pressure (WCK 6.8) or flow instability (MEK 1.6). Periphyton biomass did not reach nuisance levels at any site, but sites exposed to ORNL pollutants had moderately high levels of periphyton biomass. Annual mean photosynthetic rates were not significantly different for most White Oak Creek sites, except for the reference site WCK 6.8 , where rates were very low.

As seen in previous years, downstream sites (WCK 2.3-3.4) had relatively high photosynthesis per chlorophyll compared to WCK 3.9. Relatively low chlorophyll-adjusted photosynthetic rates at WCK 3.9 may reflect direct or indirect effects of ORNL toxicants such as chlorine.

The pattern of chlorophyll $a$ over six years illustrates few noteworthy trends. Chlorophyll $a$ at most White Oak Creek sites did not exhibit steady upward or downward movement from 1988 to 1993. Year-to-year variability was fairly low; the range in chlorophyll $a$ was $<6 \mu \mathrm{g} / \mathrm{cm}^{2}$ for most sites. However, there did appear to be an upward trend at WCK 3.9, where mean annual chlorophyll $a$ consistently increased from 1989 through 1993. WCK 3.9 has been characterized as a chlorine-impacted site in previous years. Increasing chlorophyll $a$ at this site may indicate a reduction in chlorine (or decreased effects of other, unidentified toxicants) and is consistent with increased fish populations and increased survivorship in toxicity tests for this site.

\subsubsection{Benthic Macroinvertebrates}

During the characterization phase of the ORNL Biological Monitoring and Abatement Program (May 1986 through April 1988), the benthic macroinvertebrate communities of the streams downstream from ORNL discharges exhibited characteristics indicative of degraded water quality. These impacted reaches were typically characterized by low taxonomic diversity and richness, and the absence or low relative abundance of major taxonomic groups that are generally intolerant of pollution (e.g., Ephemeroptera, Plecoptera, and Tricoptera). Studies 
of benthic communities continued after 1988 with the specific objectives of (1) identifying and documenting impacts associated with past and current ORNL operations, (2) continuing efforts to help identify causal factors responsible for any observed adverse impacts, and (3) documenting the responses of these communities to remedial actions.

Benthic macroinvertebrate samples are collected quarterly from 15 sites on streams around ORNL (Fig. 5.1). At each site, three randomly selected benthic macroinvertebrate samples were collected from a riffle at each stream site with a Surber stream bottom sampler. Samples are placed in pre-labeled glass jars and preserved in $80 \%$ ethanol. Due to a backlog in sample processing, this report presents results only through April 1992.

Total density appeared to be an insensitive indicator of impacts of ORNL discharges on stream invertebrate communities in the April 1992 data. Mean densities of invertebrates at reference sites ranged from 1533 organisms $/ 0.1 \mathrm{~m}^{2}$ at Fifth Creek kilometer (FFK) 1.0, the highest value among all sites, to 456 organisms $/ 0.1 \mathrm{~m}^{2}$ at Northwest Tributary kilometer (NTK) 1.0. A pattern of density dominance by chironomids (a midge larvae generally tolerant of pollution) below ORNL discharges was observed in all streams.

Taxonomic indices, such as total taxonomic richness and Ephemeropter, Plecoptera, and Tricoptera richness, have proven to be highly sensitive indicators of environmental degradation in the past. In April 1992, mean total richness was significantly depressed relative to the pooled reference site (mean $\pm \mathrm{SE}, 30.2 \pm 0.93$ ) at all sites downstream from ORNL discharges except NTK 0.2. Mean Ephemeropter, Plecoptera, and Tricoptera richness was significantly lower than the pooled reference site mean, $13.8 \pm 0.70$, at all sites except Melton Branch kilometer [MEK 1.2].

Total and Ephemeropter, Plecoptera, and Tricoptera richness were lower at the downstream sites in First Creek and Fifth Creek than in the upstream reference sites. Although there has been improvement in both parameters over time in Fifth Creek, the April 1992 values were no different than values from 1991. There is no apparent temporal trend in First Creek.

In Melton Branch, total and Ephemeropter, Plecoptera, and Tricoptera richness in the downstream locations had reached levels equivalent to the upstream reference site in 1991 . The April 1992 values for both indices were similar to 1991 values.

Total richness and Ephemeropter, Plecoptera, and Tricoptera richness were significantly lower than the mean values at both the upstream reference and the pooled reference sites at all sites in White Oak Creek downstream from ORNL discharges. WCK 3.9 stands out as the most impacted site, with the lowest mean values for total and Ephemeropter, Plecoptera, and Tricoptera richness of any site in the study. Ephemeropter, Plecoptera, and Tricoptera and total richness indices at the remaining White Oak Creek sites were similar. Values of these indices were higher in 1992 than in 1987, the first year of monitoring, and appear to have increased somewhat since 1987/1988. They nevertheless remain at levels characteristic of a significant adverse impact.

\subsubsection{Fishes}

Fish population and community studies can be used to assess the ecological effects of changes in water quality and habitat. These studies offer several advantages over other 
indicators of environmental quality and are especially relevant to assessment of the biotic integrity of White Oak Creek. For example, fish communities include several trophic levels, and species that comprise the potential sport fishery in White Oak Creek are at or near the end of food chains. Consequently, they potentially integrate the direct effects of water quality and habitat changes on primary producers (periphyton) and consumers (benthic invertebrates) that are utilized for food. Because of these trophic interrelationships, the well- being of fish populations has often been used as an index of water quality. The initial objectives of the instream fish monitoring task were (1) to characterize spatial and temporal patterns in the distribution and abundance of fishes in White Oak Creek and (2) to document any effects on fish community structure and function resulting from implementation of remedial actions associated with the ORNL Water Pollution Control Program and the ER Program.

Quantitative sampling of the fish populations at 15 sites in White Oak Creek watershed (Fig. 5.1) was conducted by electrofishing in April-May and October-November 1993. The resulting data were used to (1) determine species composition; (2) estimate population size (numbers and biomass per unit area); (3) determine length-frequency relationships among each species at each site; and (4) calculate annual production values.

Thirteen species were collected in quantitative surveys of White Oak Creek in 1993. Nine species were found at the lowermost site (WCK 2.3). Intermediate sites on White Oak Creek (WCK 2.9 to 5.1) had three to eight species, while the uppermost reference site (WCK 6.8) had four species. The number of species in the tributaries of White Oak Creek ranged from two to eight. The patterns observed in species richness during 1993 were very similar to those found in 1985-1992. Species richness generally increased with stream size, but consistent differences in the maximum number of species were evident as a result of weirs, which act as barriers to upstream movement and tend to isolate the fish populations at some sites (e.g., Melton Branch). The slightly higher richness at WCK 2.3 was a result of its proximity to White Oak Lake.

The estimated total fish density has varied throughout the sampling periods at First Creek from fall 1985 through fall 1993. There have been no apparent decreasing or increasing trends in density at FCK 0.8 . In contrast, there has been a steady decline in the fish density at FCK 0.1 following the peak in fall 1991. Declines in fish density in lower First Creek may be a result of past problems from leaking pipes and continuing problems such as potable waterline breaks.

The fish community in Fifth Creek decreased in total estimated density and biomass from Fall 1992 to Fall 1993. These decreases were due to a decease in the number of blacknose dace at the site. There was a slight increase in stoneroller density from fall 1992 to fall 1993. It may take some time for the fish populations at FFK 0.2 to stabilize.

Total fish densities and biomass fluctuated in Melton Branch and Northwest Tributary during 1993 and did not exhibit any steady trends. There were no consistent changes in total estimated density and biomass from 1992 to 1993 within White Oak Creek. Density and biomass decreased at WCK 2.3 from spring 1992 to spring 1993 but were within the ranges from previous years. Total estimated density decreased for both spring and fall (only slightly) from 1992 to 1993 at WCK 2.9. Total biomass remained relatively the same. Total estimated density and biomass increased for spring and fall sampling periods at WCK 3.4 from 1992 to 1993 and were greater compared to previous years back to fall 1991 when the sampling reach was changed. Total density and biomass did not change dramatically at WCK 3.9 from 1992 
to 1993 . There were no substantial changes in total density and biomass from 1992 to 1993 at WCK 5.1 or 6.8 .

Length-frequency histograms represent the overall distribution of size classes of individuals within a population. The expected distribution would include a greater proportion of smaller individuals, with numbers decreasing as size increases. With the following exceptions, all fish populations that were evaluated exhibited the length-frequency distribution of a normal population. Blacknose dace did not exhibit the expected length-frequency distribution at First Creek kilometer (FCK) 0.1, WCK 3.4, WCK 3.9, MEK 0.6, and MEK 1.4. Stoneroller populations did not exhibit the expected length-frequency distribution at FFK 0.2 and WCK 2.3. Creek chub populations did not exhibit the expected length-frequency distribution at MEK 1.4, NTK 1.0, and WCK 3.9. Mosquitofish populations did not exhibit the expected length-frequency distribution at FCK 0.1. Redbreast sunfish populations did not exhibit the expected length-frequency distribution at WCK 2.9 and WCK 3.4. The bluegill populations at WCK 3.4 did not exhibit the expected length-frequency distributions. The banded sculpin did not exhibit the expected length-frequency distribution of a normal population at FFK 1.0 or WCK 6.8 .

Annual production during 1992 to 1993 at the upper White Oak Creek sites (WCK 5.1 and 6.8) and the tributaries (all 3rd order or smaller sites) was highly variable. The total community production at the reference sites (WCK 6.8, FFK 1.0, FCK 0.8, MEK 2.1, and NTK 1.0) ranged from 2.02 to $27.12 \mathrm{~g}$ wet $\mathrm{wt} / \mathrm{m}^{2} / y e a r$, and impacted sites showed a similar range (2.84 to $22.66 \mathrm{~g}$ wet $\mathrm{wt} / \mathrm{m}^{2} / \mathrm{year}$ ). Comparisons within streams were most similar at Northwest Tributary. Production at the lower White Oak Creek sites during the 1992 to 1993 period ranged from 3.65 to $22.66 \mathrm{~g}$ wet $\mathrm{wt} / \mathrm{m}^{2} / \mathrm{yr}$. These values are similar to those for the 1991 to 1992 period.

\subsection{RADIOECOLOGY OF WHITE OAK LAKE}

The purpose of the radioecology studies in White Oak Lake is to provide information that can be used (1) to establish an inventory of radionuclides in the biotic and abiotic components of White Oak Lake and its floodplain and (2) to assess the potential for exposure to radionuclides via the foodchain in the lake and floodplain. This study includes White Oak Lake, White Oak Creek Embayment, and other radioactive contaminated areas in the Oak Ridge Reservation. Included in this section are results of studies on the resident Canada goose population, analyses of radiological contaminants in waterfowl from the Oak Ridge Reservation, and remedial actions taken to prevent geese from visiting White Oak Lake and radioactive waste ponds. In addition, data are provided on the concentrations of ${ }^{137} \mathrm{Cs}$ in largemouth bass, bluegill, and redbreast sunfish in White Oak Lake and White Oak Creek Embayment and floating vegetation on White Oak Lake and White Oak Creek Embayment.

\subsubsection{Waterfowl Studies}

A weekly census of waterfowl associated with Oak Ridge Reservation has continued through 1993. The census was initiated in 1987 when most of the observation sites were in the vicinity of ORNL. The number of observational sites has been increased and now includes locations at the K-25 Site and Y-12 Plant as well as ORNL. In 1992, sites were added to include areas near the Oak Ridge Reservation where Canada goose (Branta canadensis) 
hunting occurs. These sites were monitored before and during the hunting seasons. Fifty-eight monitoring sites are currently included in the weekly census.

For the third year, a propane cannon was installed at the upper end of White Oak Lake in December to discourage Canada geese and migratory waterfowl from using the lake. In 1992, cables with streamers were placed over the radioactive equalization basin (pond 3524) and pond 3513 which are in the confines of ORNL to discourage waterfowl from using these ponds. However, when waterfowl persist in using these ponds as nesting sites, they are killed with firearms and their tissues are analyzed for radionuclides.

During the annual roundup of Canada geese on the Oak Ridge Reservation and adjacent areas, data were collected on 542 geese. Whole-body gamma detection was conducted on ten Canada geese from each area, except Solway Park and the Y-12 Plant, where five and two were analyzed, respectively. The Canada geese were returned to their original areas when the whole-body counting was completed.

The mean whole-body radioactivity of ${ }^{137} \mathrm{Cs}$ in Canada geese counted during the June $29-30,1993$ roundup varied from $0.29 \mathrm{pCi} / \mathrm{g}$ at the K-25 Site to $0.33 \mathrm{pCi} / \mathrm{g}$ at the $\mathrm{Y}-12$ plant. Values from off-site areas were $0.32-0.36 \mathrm{pCi} / \mathrm{g}$. From these data it does not appear that there is a difference in the concentration of ${ }^{137} \mathrm{Cs}$ in Canada geese collected from the Oak Ridge Reservation and adjacent areas.

Because elevated levels of PCBs were measured in fish from K-1007-P1 pond, samples of breast, liver, and bone were collected from five geese that frequented the K-25 Site and five from a reference site in September and October 1993. These samples were analyzed for PCBs. No detectable levels of PCBs were measured in any of the samples.

\subsubsection{Radioactivity in Fish}

Bluegill, redbreast sunfish, and largemouth bass were collected January and December 1992 and January 1993 from White Oak Creek, White Oak Lake, Melton Branch and Northwest Tributary. The fish were weighed and their lengths recorded. Filets were taken from each fish and analyzed for contaminants including radionuclides (see Sect. 5.3.1).

Cesium-137 concentrations were higher in sunfish from WCK 3.5 than in downstream sites, including White Oak Lake. Cesium-137 concentrations in largemouth bass from White Oak Lake were $\sim 100$ times as high as those in bluegill from White Oak Lake.

\subsubsection{Radioactivity in Floating Vegetation in White Oak Creek Embayment}

Floating vegetation on the surface of White Oak Lake and White Oak Creek Embayment is an attractive food source for late-season wood ducks and migratory waterfowl passing through the area in October when a blanket of vegetation often covers the water. These floating macrophytes, which accumulate radionuclides $\left({ }^{137} \mathrm{Cs},{ }^{60} \mathrm{Co}\right.$, and $\left.{ }^{90} \mathrm{Sr}\right)$ from the water, are a direct link in the waterfowl-to-human foodchain.

A coffer-cell dam was installed at the mouth of White Oak Creek in 1992 to prevent contaminated sediment in White Oak Creek Embayment from being transported into the Clinch River. The 8.3 acre impoundment created by the dam has been covered with floating vegetation in the summer and fall of 1992 and 1993. The purpose of this study was to 
determine the inventory of ${ }^{137} \mathrm{Cs}$ and ${ }^{60} \mathrm{Co}$ in floating vegetation in White Oak Creek Embayment.

Higher concentrations of ${ }^{137} \mathrm{Cs}$ were found in floating vegetation at the upper end of White Oak Creek Embayment ( 284 pCi/g dry wt.) than the lower end near the coffer-cell dam (171 pCi/g dry wt.). During September 1993 concentrations were slightly higher at the upper end of White Oak Creek Embayment $(6 \mathrm{pCi} / \mathrm{L})$ than at the lower end near the coffer cell dam (3 pCi/L). During August 1993, higher concentrations of ${ }^{137} \mathrm{Cs}$ in water were found in the upper end of White Oak Lake (22 pCi/L) than during September 1993 ( $3 \mathrm{pCi} / \mathrm{L})$.

In September 1993, approximately $70 \%$ of the water surface of the embayment was covered by floating vegetation. The embayment was estimated to contain approximateiy $357 \mathrm{~kg}$ (dry wt.) of floating vegetation and have an inventory of approximately $81 \mathrm{mCi}$ of ${ }^{137} \mathrm{Cs}$ and $6 \mathrm{mCi}$ of ${ }^{60} \mathrm{Co}$. With the coffer-cell dam at the mouth of White Oak Creek, the embayment is covered with water the year round and provides an excellent habitat for both resident and migratory waterfowl. During the summer and fall floating vegetation are readily available to waterfowl and provide a source of ${ }^{60} \mathrm{Co}$ and ${ }^{137} \mathrm{Cs}$.

\subsection{SUMMARY}

The primary objective of the monitoring tasks described in Sects. 5.2-5.6 is to provide sufficient data to demonstrate that effluent limitations established for ORNL protect and maintain the classified uses of White Oak Creek and Melton Branch (Loar 1991). Those uses are (1) growth and propagation of fish and aquatic life and (2) livestock watering and wildlife. The purpose of this section is to integrate these individual tasks and provide a bottom line answer to the question of whether or not the classified uses are being maintained.

\subsubsection{Growth and Propagation of Fish and Aquatic Life}

Most of the data provided in this monitoring effort is pertinent to evaluating the suitability of the five streams for growth and propagation of aquatic life. Because not all tasks monitor exactly the same sites, the data in this section are grouped into eight primary reaches.

Reach 1 Lower Fifth Creek (represented by FFK 0.2).

Reach 2 Lower First Creek (represented by FCK 0.1)

Reach 3 Lower Northwest Tributary (represented by NTK 0.2)

Reach 4 Lower Melton Branch downstream of the HFIR discharges (represented by MEK 1.2 and 0.6 )

Reach 5 White Oak Creek upstream of the main plant area but downstream of the 7000 complex (represented by WCK 5.1)

Reach 6 White Oak Creek adjacent to the main plant area (represented by WCK 3.9 and 3.4)

Reach 7 White Oak Creek downstream of the 7500 bridge (represented by WCK 2.9 and 2.3)

In 1993, for the second consecutive year, ambient toxicity tests provide no indication of acute or chronic toxicity at any of the 15 test sites. Thus, the toxicity test data would suggest that all reaches are capable of supporting growth and propagation of fish and aquatic life. 
With the exception of WCK 3.9 (see discussion on Reach 6), periphyton generally exhibits two trends that may be related to ORNL discharges. In all reaches, biomass is greater at downstream sites than at reference sites. This may be due to nutrient enrichment, to lack of grazers, or to low/no flow conditions at some reference sites (i.e., MEK 1.6). The second trend is for diatom abundance to increase with distance downstream from ORNL discharges. Thus, with the exception of WCK 3.9, all downstream sites show some impacts compared with reference sites, but the role of contaminants in those impacts is unclear.

Health of the redbreast sunfish population in White Oak Creek continues to be different than that of redbreast sunfish populations in reference streams. However, since 1989, there has been a consistent trend toward improvement in the White Oak Creek population relative to the reference sites.

Water and foam samples from five streams near ORNL were analyzed for lipid content, lipid-class composition, and PCBs in 1993. Lipid contents showed much variation and were always greater in foams than in subsurface water. Stream foams were also enriched in PCBs as compared to concentrations in subsurface waters. Foams in lower White Oak Creek and Bear Creek contained hydrocarbons, suggesting petroleum product contamination.

\subsubsection{Reach 1 Fifth Creek}

Despite improvement, the benthic invertebrate community at FFK 0.2 remains impacted. A pattern of numerical dominance by chironomids below ORNL discharges is apparent at FFK 0.2. Total and Ephemeropter, Plecoptera, and Tricoptera richness in April 1992 were lower than in the reference site at FFK 1.0.

Total fish density and biomass declined slightly from 1992 at FFK 0.2 , but levels are still higher than in pre-1991 years. Species richness remained the same in 1993 as in 1992.

Reach 1 may be viewed as still impacted. Improvements in previous years were still evident in 1993, though no further improvement was apparent.

\subsubsection{Reach 2 First Creek}

Total benthic invertebrate density continued to follow no clear temporal trend at FCK 0.1. Chironomids dominate the benthic fauna at this site but make up a much smaller proportion of the community at the upstream reference site (FCK 0.8). Total and Ephemeropter, Plecoptera, and Tricoptera richness were very much lower at FCK 0.1 than at FCK 0.8 .

Lower First Creek exhibited a decline in the fish community in 1993. Total fish density and biomass declined from 1992 levels.

This reach continues to be impacted. Conditions may have declined during 1993 as indicated by the declining fish community.

\subsubsection{Reach 3 Northwest Tributary}

Mean benthic invertebrate density at NTK 0.2 was similar to density at the upstream reference site in April 1992. The pattern of chironomid dominance noted at other ORNL 
sites was not present at NTK 0.2. Total and Ephemeropter, Plecoptera, and Tricoptera richness were similar at both sites on Northwest Tributary. While total fish density declined during 1992 at NTK 0.2, biomass increased.

Reach 3 appears to be relatively unimpacted, and all monitoring parameters suggest that this reach will support growth and propagation of fish and aquatic life.

\subsubsection{Reach 4 Melton Branch}

Between 1988 and 1991, the benthic communities at all three Melton Branch sites appeared very similar, although there were subtle indications of potential impacts at MEK 1.2 and MEK 0.6. In 1992, total richness at MEK 1.2 was significantly lower than at the upstream reference site or the pooled mean of all reference sites. Also, chironomids tended to dominate the benthic fauna at both the lower sites.

Fish density fluctuated at all three sites during 1993. Blacknose dace populations at both downstream sites and the creek chub population at MEK 1.4 did not exhibit the lengthfrequency pattern typical of balanced populations. These two species did exhibit balanced length-frequency patterns at the upstream site.

Given the exigencies of flow perturbations in Melton Branch, reach 4 appears to be largely unimpacted by ORNL discharges and will support growth and propagation of fish and aquatic life.

\subsubsection{Reach 5 White Oak Creek Upstream of the ORNL Main Plant Area}

Periphyton communities in reach 5 were in good physiological condition and had high biomass and photosynthesis rates. However, chlorophyl-adjusted photosynthesis has decreased at WCK 5.1, perhaps due to establishment of a snail population at this site during 1993.

The benthic invertebrate community at WCK 5.1 has exhibited improvement in total and Ephemeropter, Plecoptera, and Tricoptera richness during 1990 and 1991. However, richness at WCK 5.1 is still much lower than at the WCK 6.8 reference site. The fish community at WCK 5.1 appears to be stable. Embryo-larval toxicity tests performed using Japanese Medaka embryos strongly suggest that there is a major source of toxicity located between WCK 5.1 and WCK 4.4.

Reach 5 is generally suitable for growth and propagation of fish and aquatic life. However, toxic discharges in the lower portion of this reach may produce localized areas where aquatic life are impacted.

\subsubsection{Reach 6 White Oak Creek Adjacent to the ORNL Main Plant Area}

Periphyton at WCK 3.9 was dominated by unicellular prostrate green algae that are commonly found at chlorine-impacted sites. Chlorophyl-adjusted photosynthesis at WCK 3.9 was lower than at other sites on White Oak Creek. Biomass at WCK 3.9 has increased from 1989 to 1993 , but it is unclear if this was due to improvements in water quality or to other factors. 
Chironomids dominate the benthic invertebrate community at both sites in reach 6 . WCK 3.9 has the lowest total and Ephemeropter, Plecoptera, and Tricoptera richness of any site studied. Total and Ephemeropter, Plecoptera, and Tricoptera richness at WCK 3.4 are both significantly lower than at the upstream reference site. Fish density and biomass increased from 1992 at both WCK 3.4 and WCK 3.9. Survival of Japanese Medaka embryos in water from two sites in reach 6 were much lower than survival of controls.

Reach 6 exhibits mixed signals with regard to suitability for growth and propagation of fish and aquatic life. Fish communities do not appear significantly impacted and have improved since 1992. However, low survival of Japanese Medaka embryos suggests that some fish species may have difficulty establishing populations in reach 6 . Other aquatic life may be impacted in reach 6 as evidenced by the poor condition of the periphyton and benthic invertebrate communities, especially at WCK 3.9.

\subsubsection{Reach 7 White Oak Creek Downstream of the ORNL Main Plant Area}

Benthic communities in this reach are dominated by chironomids. Although total and Ephemeropter, Plecoptera, and Tricoptera richness have increased since 1987, sites in this reach are still impacted compared with reference sites. There were no consistent changes in the density or biomass of the fish community in this reach.

Survival of Japanese Medaka embryos in water from two sites in reach 7 were much lower than survival of controls. Reach 7 may be less than fully suitable for growth and propagation of some fish species and other aquatic life.

\subsubsection{Wildlife}

Data from the aquatic bioaccumulation studies, raccoon monitoring, and radioecology of White Oak Lake, may be used to address this classified use. Biomonitoring results indicate that fish in the White Oak Creek watershed are contaminated with mercury and PCBs. The radioecology studies in White Oak Lake indicate that sunfish and largemouth bass contain

${ }^{137} \mathrm{Cs}$. Results of the raccoon monitoring indicate that White Oak Creek raccoons accumulate mercury and ${ }^{137} \mathrm{Cs}$ from their environment. Floating vegetation in White Oak Lake and White Oak Creek Embayment are a source of ${ }^{60} \mathrm{Co}$ and ${ }^{137} \mathrm{Cs}$ to migratory and resident waterfowl.

Raccoons collected in 1993 from the White Oak Creek and Melton Branch floodplains were contaminated with ${ }^{60} \mathrm{Co}$ and ${ }^{137} \mathrm{Cs}$, as has been the case for 1991 and 1992 . The proportion of raccoons contaminated with ${ }^{60} \mathrm{Co}$ is similar to results in 1992; however, the proportion of raccoons contaminated with ${ }^{137} \mathrm{Cs}$ was substantially lower. These fluctuations are most likely related to year to year differences in food sources.

Trace metals analyses were conducted on three kingfisher carcasses collected on the Oak Ridge Reservation in 1993. All three birds contained measurable levels of $\mathrm{Cd}$ and $\mathrm{Hg}$ in their internal organs, even though they were collected from very different locations. Limited data indicate that feathers are an excellent tissue to monitor $\mathrm{Cd}, \mathrm{Hg}, \mathrm{Pb}$, and $\mathrm{Se}$. The presence of $\mathrm{Cd}$ in all three samples suggest that more attention should be directed to this contaminant in future monitoring and assessment efforts.

Only one mink was collected in 800 trap nights during 1993. A radio transmitter was implanted in this mink permitted tracking for two months before the signal was lost. Samples 
for fat and hair were collected from roadkills; however, laboratory results have not been completed.

Clearly wildlife are being contaminated in the White Oak Creek watershed. One source of this contamination may be historic sources such as the burial grounds. 


\title{
6. CONTAMINANTS OF CONCERN AND RISK ASSESSMENT
}

\author{
S. T. Purucker, D. S. Jones, and G. W. Suter II
}

\subsection{INTRODUCTION}

This chapter builds on data provided in previous chapters, especially those on surface water and groundwater, and summarizes the human health risk and ecological risk assessments performed on ORNL WAGs. The methodologies used for conducting risk assessments on source operable units as distinguished from integrator operable units, are also reviewed. The results of specific risk assessments for the ORNL WAG source units and for the WAG 2 integrator unit are presented, and separate sections cover issues related to human health risk analysis and challenges for ecological risk analysis on the Oak Ridge Reservation.

\subsubsection{Section Outline}

Section 6.2 explains the approach used to assess risk by media at source control and integrator operable units and summarizes the contaminants of concern and the results of human health risk assessments performed at ORNL.

Section 6.3 reviews the recent progress in ecological risk assessments.

Section 6.4 provides a section summary.

\subsubsection{Assessment and Decision Making}

The ER Program strives to select from a range of alternatives the remediation plan that best satisfies defined acceptable risk criteria. Deciding how to proceed under significant uncertainties creates a challenge for environmental cleanup activities. To reduce these uncertainties the ER Program expends considerable effort and resources collecting site characterization data. These data shed light on whether the proposed action is needed and, if so, the type of action to implement. Risk assessment activities at ORNL focus on (1) assessing the need for remediation in a consistent manner, (2) supporting remedial action decisions, and (3) helping prioritize remedial resources. The WAG 2/SI addresses these issues by assessing risk in a manner consistent with the conceptual model for ORNL and ensuring early involvement in the decision process by decision makers.

The WAG 2/SI Project is a multiyear effort and collects data to assess four different media (biota, soil and sediment, groundwater, and surface water). Presenting data this way meets the general goals of providing an annual summary of the environmental data collection; performing risk-based prioritizations; and communicating information to the public, regulators, and DOE managers. These different media require their own specific problem statements and risk-based decision rules to adequately support different aspects of remediation activities and prioritization at the source operable units. They are developed independently in the following sections. However, these media form the elements of an integrated measure of contaminant release from all sites and provide baselines for measuring the performance of remedial efforts. 


\subsection{HUMAN HEALTH RISK ASSESSMENT AND CONTAMINANTS OF CONCERN}

This section describes the approach of human-health risk assessments and uses the results to identify contaminants of concern for the different media that are sampled as part of the WAG 2/SI.

\subsubsection{Surface Water}

WAG 2, the surface water integrator operable unit at ORNL, is part of an integrated hydrologic system. Surface water transports dissolved contaminants and contaminants bound to suspended particles from the White Oak Creek watershed to White Oak Dam. Contaminants released in surface water over White Oak Dam are transported into the Clinch River. Surface water serves as the primary pathway for contaminant release off the Oak Ridge Reservation.

The analysis of risk related to exposure to surface water is divided among four topics: (1) methods for calculating the risk due to ingestion of surface water, (2) contaminants of concern in surface water, (3) historical trends in the main contaminants of concern, and (4) prioritization of the WAGs for remedial actions based on risk analysis of surface water discharges.

\subsubsection{Calculation of risk}

The ER Program pays close attention to the risk due to ingestion of water discharged at White Oak Dam, however, there are alternative ways to evaluate the parameters in the risk calculations. ER program managers strive to develop a uniform approach to risk calculations so that risk estimates can be compared across all program activities.

The risk for each contaminant is a function of parameters describing the exposure, the dose-response relationship, and the representative contaminant concentration. Risks for all contaminants are summed to yield the risk parameter. For the ingestion exposure, it is assumed that an individual drinks the water at rate of $2 \mathrm{~L}$ per day, 350 days per year, for 30 years. Furthermore, it is assumed that the representative concentration remains fixed for the entire 30 years. Alternative methods for calculating risk involve (a) the method to determine the representative concentration and (b) the selection of parameters for the doseresponse relationships. These alternative methods are investigated here. As will be shown, the differences are sufficiently large to warrant examination.

The main risk value used in prioritization of ER activities is the annual risk, and the representative concentration used in the calculation is the average annual contaminant concentration. This average concentration can be computed as either the simple 12-month average or as the flow-weighted average of monthly values. There are justifications and drawbacks for both averages. For the simple average the exposed individual drinks the same amount of water each month regardless of flow. In contrast, the flow-weighted approach implies that the individual drinks more water in March when flow is usually large and less in October when flow is low. In concept, use of the flow-weighted average assumes that the water discharged over an entire year is first contained in a hypothetical reservoir, then the individual drinks steadily from that reservoir (see Fig. 1.10 for the application of this idea to WAG 6). Though slightly less realistic, the flow-weighted approach provides a better accounting of the mass balance of contaminants and therefore provides ER management a 
useful tool for managing contaminant releases. Water at White Oak Dam is viewed as a mixture from upstream sources, each with its own flow-weighted concentration that can be converted to a risk value. In turn, comparisons of these risk values to that at White Oak Dam lead to the prioritization of sites that are listed later. Likewise, risk to the off-site individual drinking water from the Clinch River can be computed by diluting the flow-weighted concentrations at White Oak Dam by using the measured flows in the Clinch River.

The other variable in the calculation of risk is the selection of the parameters in the dose-response relationships. One can use either the ingestion slope factors currently recommended by U.S. Environmental Protection Agency or the dose conversion factors that reflect recent revisions by experts. It is expected that the new dose conversion factors will become standard soon.

The recommended radionuclide slope factors from U.S. Environmental Protection Agency for CERCLA projects are issued annually in the Health Effects Assessment Summary Tables (EPA 1993). The radionuclide slope factors are calculated for each radionuclide individually based on its radioactive, metabolic, and chemical properties. The slope factors are the average risk per unit intake or exposure for a U.S. individual with 1970 mortality rates. The current U.S. Environmental Protection Agency-recommended radiation risk factors are based on the 1980 National Academy of Sciences Biological Effects of Ionizing Radiation Committee (NAS/NSC 1980) report. The NAS/NSC (1980) recommendations were increased slightly by U.S. Environmental Protection Agency to reflect recent information on the health effects of exposure to ionizing radiation.

In 1990, the National Academy of Sciences published the results of the most recent studies of the health effects of ionizing radiation, the NAS/NSC (1990) report, which increases the estimates of cancer risk by a factor of 3 to 5 over the previous NAS/NSC (1980) report. These increases are based primarily on a reevaluation of doses received by atomic bomb victims. It is expected that the radionuclide slope factors will be reissued during 1994 and that the values will be 2 to 3 times higher than the current Health Effects Assessment Summary Tables value in many cases (Akin 1994). Recommended dose conversion factors are incorporated in the computer code DFINT (Eckermann 1993). These numbers represent a best (50th percentile estimate based on a linear dose-response relationship. This value is multiplied by a risk conversion factor to establish a functional slope factor similar to those published in Health Effects Assessment Summary Tables. The risk conversion factor used is 0.073 Risk/Sievert(Sv) and is given in ICRP (1991) and NCRP (1993). This value includes the risk of dying of cancer $(0.05 / \mathrm{Sv})$, other occurrences of cancer $(0.01 / \mathrm{Sv})$, and the risk of genetic effects $(0.013 / \mathrm{Sv})$. The newly revised dose conversion factors derived from these recent reports and the slope risk factors currently recommended by U.S. Environmental Protection Agency are the alternative choices for risk calculations.

Annual risk due to ingestion of surface water has been computed using the two methods for calculating the annual average concentration and the two methods for determining the dose-response relationship. Figure 6.1 presents annual estimates of the drinking water ingestion risk at White Oak Dam for 1987 through 1993 based on these alternative methods. The same order of magnitude for risk is calculated regardless of which permutation is used: all of the results for 1993 fall within the range of 3 to $6 \times 10^{-4}$. As expected, the calculated risk is greater using the dose conversion factor. The risk is also slightly higher using the flowweighted annual average concentrations for contaminants, although use of this averaging method has less effect than the dose-response parameter. In all cases, the risk at White Oak 


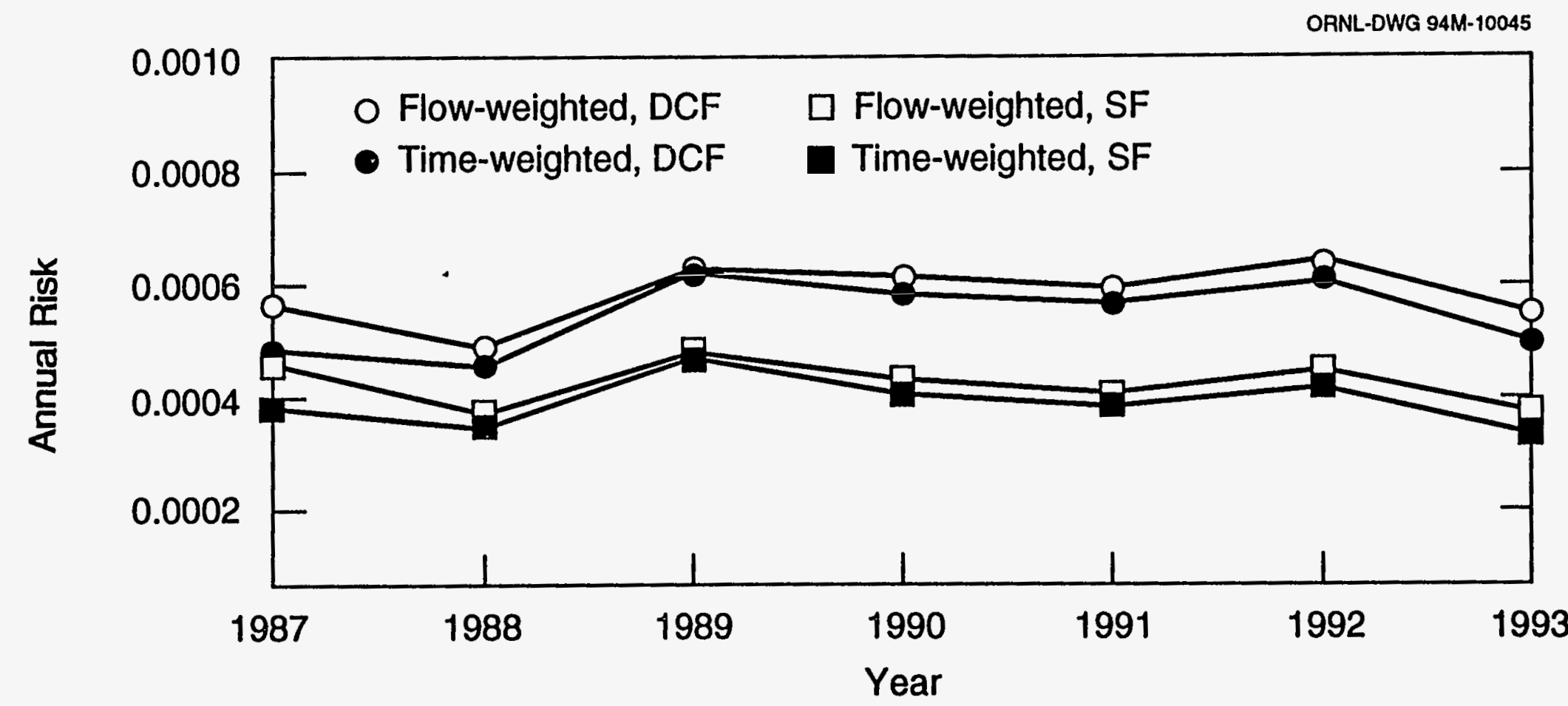

Fig. 6.1. Annual estimates of ingestion risk at White Oak Dam. 
Dam exceeds the U.S. Environmental Protection Agency target goal of $1 \times 10^{-4}$.

\subsubsection{Contaminants of concern in surface water}

Risk calculations have been made for individual contaminants which are classified as carcinogens. In addition, the hazard index has been computed for noncarcinogens. Index values greater than unity (or zero on a log scale) are unacceptable for maintaining human health.

For the period 1987 through 1993, Fig. 6.2 shows the statistical distributions of risk and the hazard index based on monthly concentrations at White Oak Dam using dose conversion factors. The radionuclides were decay adjusted. The high-priority contaminants of concern at White Oak Dam are ${ }^{90} \mathrm{Sr}$ and ${ }^{3} \mathrm{H}$, based on their individual carcinogenic risk exceeding $1 \times 10^{-4}$. Cesium-137 shows marginal risk, however, for this radionuclide the potential path of exposure is more likely to be related to gamma radiation from exposed sediments, not ingestion. No noncarcinogenic high priority contaminants of concern were identified. Statistical distributions of risk are also shown in Fig. 6.2 for ingestion of water in the Clinch River based on measured flow rates and the assumption of complete dilution.

As shown in Fig. $6.2,{ }^{90} \mathrm{Sr}$ is the predominant risk. When the newly revised dose conversion factors are not used in the calculations, ${ }^{3} \mathrm{H}$ accounts for most of the risk. Choice of source control remedial actions may depend on whether ${ }^{90} \mathrm{Sr}$ or ${ }^{3} \mathrm{H}$ is driving the overall risk, therefore the use of dose conversions factor versus the slope factors has important implications to the ER Program. From a practical viewpoint for interim actions, standard engineering alternatives can reduce ${ }^{90} \mathrm{Sr}$ fluxes more effectively than ${ }^{3} \mathrm{H}$ fluxes. Strontium-90 can be adsorbed and removed using zeolites whereas ${ }^{3} \mathrm{H}$ can be removed effectively only by evaporation or held in place by hydrologic isolation, both of which are relatively difficult to accomplish in the field.

\subsubsection{Trends}

Figure 6.3 depicts the 12-month moving average of the risk at White Oak Dam over the last 7 years and the relative contribution of ${ }^{90} \mathrm{Sr},{ }^{137} \mathrm{Cs}$, and ${ }^{3} \mathrm{H}$ to the overall risk. The figure suggests that the relative contribution of ${ }^{90} \mathrm{Sr}$ to risk has been increasing over time. Furthermore, this relative trend has increased at an even faster rate than can be explained by the radioactive decay rates. These decay rates are shown as straight lines in Fig. 6.3. Holding constant all other factors and the relative contributions of ${ }^{137} \mathrm{Cs},{ }^{3} \mathrm{H}$, and ${ }^{90} \mathrm{Sr}$ to risk, we would expect the relative contribution rates to follow the natural decay rate lines, i.e., the straight lines shown in Fig. 6.3. Thus if radionuclide flux remained steady at the December 1987 levels, then relative contaminant risk would closely track the decay lines. A trend would then emerge that the contribution of ${ }^{90} \mathrm{Sr}$ relative to ${ }^{3} \mathrm{H}$ has increased simply due to the ${ }^{3} \mathrm{H}$ 's shorter half life. The evidence shows that the relative ${ }^{90} \mathrm{Sr}$ contribution to risk has increased at an even faster rate than can be explained solely by its longer decay process. The ${ }^{3} \mathrm{H}$ concentration has been observed to decrease even more than its decay rate would explain. The explanation is the decreased discharge of ${ }^{3} \mathrm{H}$, as described in Sect. 2.

\subsubsection{Prioritization}

Contaminants and source areas are prioritized by using exposure parameters, dose conversion factors, and flow-weighted contaminant fluxes to calculate the ingestion risk at 


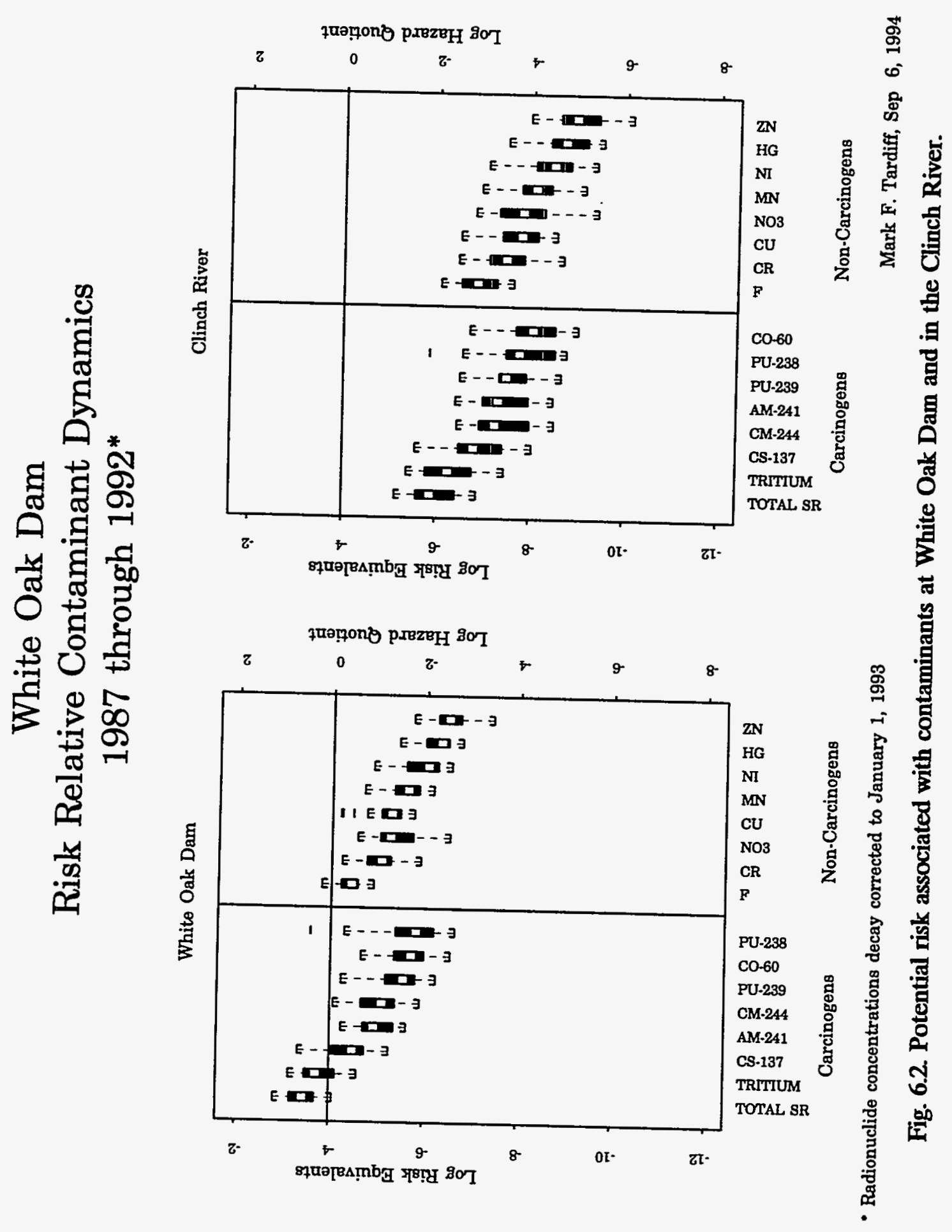




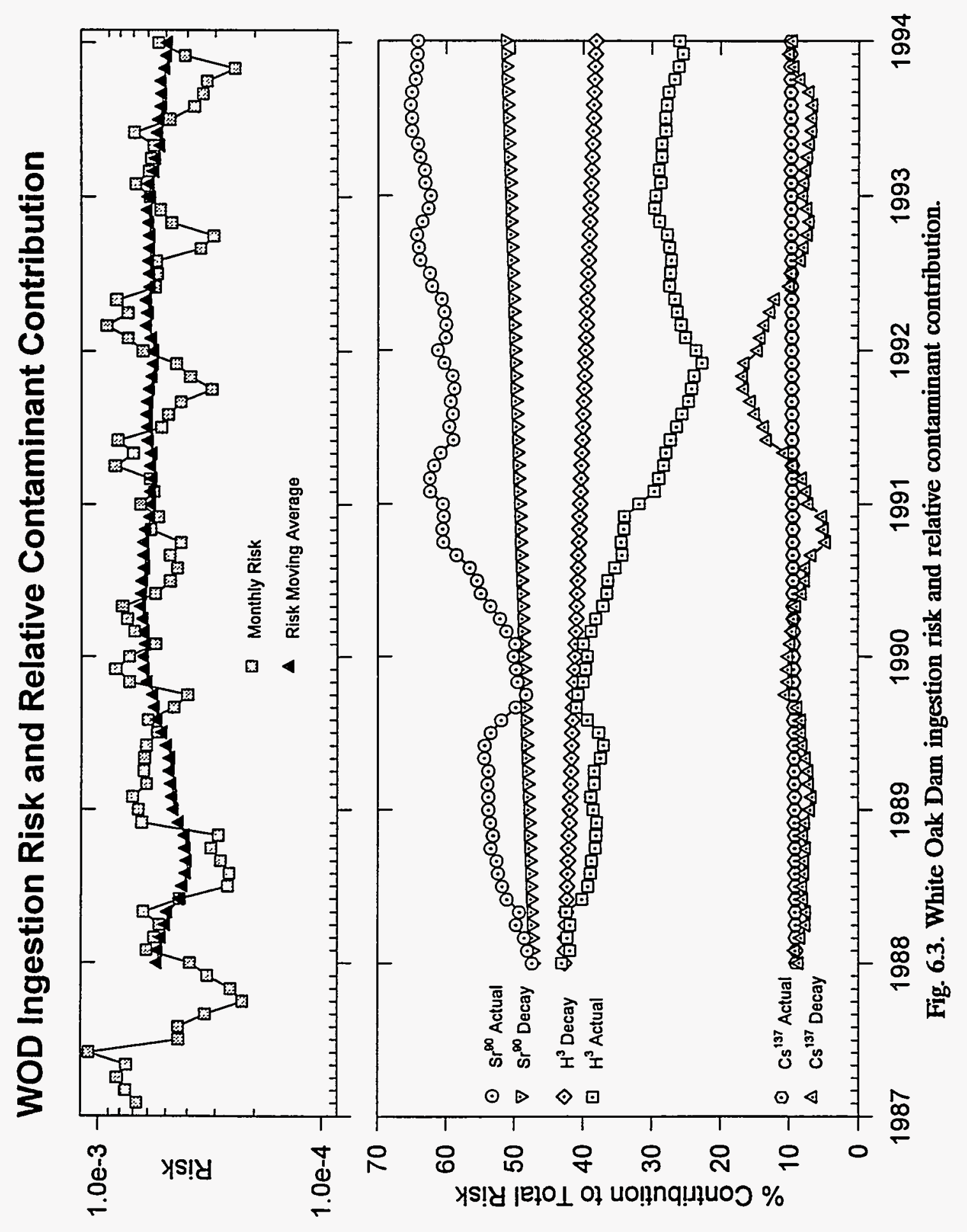


White Oak Dam. The last 7 years of concentration and flow data have been used to calculate the risk in this manner. In concept, each source area drains to a single collection point, and the concentrations of contaminants of concern at this point are multiplied by risk factors and flow volumes and compared to these same parameters at the White Oak Dam integration point. This process yields a relative contribution by a WAG to the off-site risk attributed to discharges at White Oak Dam. These contributors can then be ranked and prioritized on a common risk scale. Table 6.1 shows the ranking, and thus the initial priority for remediation, of the ORNL WAGs to off-site releases. Actual remediation priorities will depend on cost, feasibility, stakeholder preferences, and other program goals. Current Early Actions and planned Interim Remedial Actions are specifically aimed at reducing the flow of the ${ }^{90} \mathrm{Sr}$ to White Oak Dam and off-site. $\mathrm{A}^{90} \mathrm{Sr}$ removal system at Seeps $\mathrm{C}$ and D below WAG 5 is being constructed, and systems for removing ${ }^{90} \mathrm{Sr}$ from the Corehole 8 plume in WAG 1 and from the tributary in WAG 4 are in the planning stages.

Table 6.1. WAG prioritization and percent contribution to White Oak Dam risk

\begin{tabular}{lll}
\hline WAG 5 & $59 \%$ & $\pm 7 \%$ \\
WAG 1 & $18 \%$ & $\pm 6 \%$ \\
WAG 4 & $17 \%$ & $\pm 4 \%$ \\
WAG 9 & $4 \%$ & $\pm 3 \%$ \\
WAG 6 & $2 \%$ & \\
WAG 3 & $<2 \%$ & \\
WAG 7 & $<2 \%$ & \\
\hline
\end{tabular}

\subsubsection{Groundwater}

The conceptual model for ORNL closely links the groundwater and surface water regimes. In the hilly terrain, virtually all the water permeates the soil and eventually migrates to local streams through either the shallow subsurface stormflow zone or the thin layer at the top of the groundwater zone. Two facts have important implications for identifying waterborne contaminants of concern and assessing off-site risks: (1) nearly all water moves to local streams, and (2) virtually no deep groundwater moves out of the watershed. As a consequence, the groundwater operable unit requires a different type of risk assessment support because the primary driver for groundwater remediation most likely will be risk to some hypothetical on-site individual. The exposure for that on-site individual will be defined by a future land-use scenarios that are not currently agreed upon.

At this point in time, the assessment strategy for the groundwater operable unit involves risk characterization on a well-by-well and a subcatchment basis, usually along the downgradient edge of a WAG. Furthermore, groundwater quality is not regulated like other environmental media. Consequently, there are no mandated groundwater quality criteria. In an effort to provide a basis for evaluating analytical results and for identifying contaminants of concern at ORNL WAGs, drinking water limits and other similar criteria have been used to screen contaminants along with risk calculations as was done for surface water. While drinking water limits are used for identifying contaminants, no members of the public are realistically going to drink groundwater from ORNL WAGs in the near future.

The contaminants that exceeded these drinking water criteria at least once during 1992 are considered contaminants of concern and are listed in Table A.2, Appendix A of 
ERMA (1993). A comprehensive list of contaminants that have been released from ORNL WAGs are identified in Table 2.2 of ERMA (1993). These contaminants were determined primarily based on information in CERCLA remedial investigations, Remedial Feasibility Investigations, site characterization reports, or environmental data packages for each WAG. Although the available information does not support full characterization of releases from each WAG, these existing reports do provide information on waste inventories within the WAG, limited data on known releases, and results of various characterization studies.

Table 6.2 lists high priority contaminants of concern based on the same conservative risk screening techniques used to address risk in surface water. Risks were calculated based on the maximum detected concentration in each of the RCRA perimeter wells. Contaminants are listed if they were detected above the mean of the reference concentration and exceed a $1 \times 10^{-4}$ carcinogenic risk level or a hazard index of 1 . The table shows that ${ }^{90} \mathrm{Sr}$ and ${ }^{3} \mathrm{H}$ are among the most common contaminants of concern identified in the groundwater at the source WAGs. In general, organic contamination was detected in localized groundwater areas and are not as prevalent site-wide as the radionuclides.

\subsubsection{Sediment and Soil}

Three assessments have been conducted which impact identification of contaminants of concern and analysis of risk in the sediments and soil of WAG 2. They include screening analyses for (1) the Clinch River downstream from the Oak Ridge Reservation (Hoffman et al. 1991), (2) the White Oak Creek Embayment (Blaylock et al. 1993), and (3) the sediment and surface water of WAG 2 (Blaylock et al. 1992).

With the exception of ${ }^{3} \mathrm{H}$ and ${ }^{90} \mathrm{Sr}$, the major contaminants in WAG 2 are associated with particle reactive contaminants in soil and sediment. Preliminary screening of contaminants in the surface water downstream of the Oak Ridge Reservation (Hoffman et al. 1991) identified White Oak Creek Embayment as a high-priority area requiring immediate consideration for remedial action. The main contaminant of concern was ${ }^{137} \mathrm{Cs}$, and the critical exposure pathway was external exposure to radionuclides. In 1992, a coffer cell dam was constructed at the mouth of the embayment to impede the off-site migration of sediment-bound contaminants.

Contaminated sediment moves off-site primarily during floods. The Sediment Transport Modeling Task within WAG 2 produces data and model simulations to quantify the transport of contaminants and predict the amount released during large storm events. These modeling results and predictions are of particular concern to risk assessment activities concerned with the potential impact of the White Oak Creek watershed on the risk in the Clinch River. Modeling results will be reported in FY 1995.

\subsubsection{Source WAGs}

Two sets of exposure assumptions reflect the current land use situation in and around the Oak Ridge Reservation. The Most Likelihood Exposure assessment provides information concerning the relative on-site risk under current land use conditions. The Integration Point assessment provides information concerning the relative contribution of the given source control operable unit to off-site contaminant transport and migration. Results of these assessments provide the ER manager with the risk-related information needed to demonstrate whether a proposed action is necessary to stabilize the site, prevent further degradation, or 
Table 6.2. Contaminants exceeding risk criteria in RCRA perimeter wells

\begin{tabular}{|c|c|c|c|}
\hline \multirow[b]{2}{*}{ WAG } & \multicolumn{3}{|c|}{ Contaminants $^{a}$} \\
\hline & Radionuclides & Metals & Organics \\
\hline 1 & ${ }^{90} \mathrm{Sr},{ }^{234} \mathrm{U}$ & $\underline{\mathrm{As}}, \underline{\mathrm{Ba}}, \mathrm{Be}, \underline{\mathrm{Cd}} \underline{\mathrm{Mn}}, \underline{\mathrm{Sb}}$ & $\begin{array}{l}\text { Vinyl Chloride, N-Nitroso-Di-N- } \\
\text { Propylamine, Carbon Disulfide, } 1,2,3 \\
\text { Trichloropropane, } 1,2 \text { Dibromo-3- } \\
\text { chloropropane, 1,2 } \\
\text { Dibromomethane, 1,4 Dioxane, 2- } \\
\text { Propenenitrile, 3,3'- } \\
\text { Dimethylbenzidine }\end{array}$ \\
\hline 2 & ${ }^{3} \mathrm{H},{ }^{90} \mathrm{Sr},{ }^{60} \mathrm{Co}$ & $\mathrm{Be}, \underline{\mathrm{As}}, \underline{\mathrm{Mn}}$ & $\begin{array}{c}\text { 1,1 Dichloroethene, Chlorobenzene, } \\
\text { Carbon Disulfide }\end{array}$ \\
\hline 3 & ${ }^{90} \mathrm{Sr}$ & $\mathrm{Be}, \underline{\mathrm{Mn}}$ & \\
\hline 4 & ${ }^{3} \mathrm{H},{ }^{90} \mathrm{Sr}$ & $\underline{\text { Ass, }} \underline{\mathrm{Mn}}$ & $\begin{array}{c}\text { 1,1 Dichloroethene, Vinyl Chloride, } \\
\text { 1,2 Dichlorobenzene }\end{array}$ \\
\hline 5 & ${ }^{3} \mathrm{H},{ }^{90} \mathrm{Sr},{ }^{28} \mathrm{Ra}$ & $\underline{\mathrm{Mn}}$ & $\begin{array}{l}\text { Vinyl Chloride, Bis-2-ethylhexyl } \\
\text { pthalate } 1,2 \text { Dichlorobenzene, } \\
\text { Carbon Disulfide }\end{array}$ \\
\hline 6 & ${ }^{3} \mathrm{H},{ }^{90} \mathrm{Sr},{ }^{60} \mathrm{Co}$ & $\mathrm{Be}$ & $\begin{array}{l}\text { 1,2 Dichloroethane, Chloroform, } \\
\text { Trichloroethene, Aroclor-1254, } \\
\text { Vinyl Chloride, Carbon } \\
\text { Tetrachloride, Carbon Tetrachloride, } \\
\text { Carbon Disulfide, Acetone }\end{array}$ \\
\hline 7 & ${ }^{3} \mathrm{H},{ }^{99} \mathrm{Tc},{ }^{60} \mathrm{Co}$ & $\mathrm{Be}, \underline{\mathrm{Mn}}$ & \\
\hline 8 & ${ }^{90} \mathrm{Sr}$ & $\underline{\text { As, }} \underline{\mathrm{Mn}}$ & \\
\hline 11 & & $\mathrm{Be}, \underline{\mathrm{Mn}}$ & \\
\hline 17 & & & $\begin{array}{c}\text { Vinyl Chloride, } 1,1 \text { Dichloroethene, } \\
1,2 \text { Dichlorobenzene }\end{array}$ \\
\hline
\end{tabular}


achieve significant risk reduction either quickly or in the long run. The results of these assessments can also be used to prioritize the source control units with respect to risk. Screening-level risk assessments were the primary method used to determine the WAG contaminants of concern. The list of contaminants for each WAG, based primarily on nonconservative screening assumptions, appears in Table A.1, Appendix A of ERMA (1993). They are summarized by individual WAG in Sect. 2.3 of the same report. Full descriptions of the risk approach for source WAGs is available in DOE (1994).

\subsection{Human Health Risk Issues}

The CERCLA investigation activities aim to gather enough information about a site to support an informed risk management decision regarding remedial alternative selection. Risk assessment is one of many tools that supports the decision-making process. However, risk assessments often seem clouded with uncertainty. A good deal of the confusion stems from two main issues: disagreement on how predictive and scientific risk assessment results are intended to be and fundamental differences in risk perception among the many stakeholders and decision-makers involved in restoration activities at the Oak Ridge Reservation.

Land use development plans attempt to get major stakeholders involved in restoration issues. A process has been initiated at the Oak Ridge Reservation level as a part of a nationwide DOE initiative to identify future use options at Department of Energy sites by 1995 . This process reflects the fact that changing missions within DOE may result in future uses of certain existing land and buildings that differ from current uses. Decisions of this type can clearly impact target cleanup levels for certain sites on the Oak Ridge Reservation.

\subsection{ECOLOGICAL RISK}

Ecological risk assessment evaluates the probability that adverse effects on nonhuman biota are occurring or will occur because of stressors (e.g., chemicals) in the environment. The goals of ecological risk assessment are to identify the magnitude, extent, and causes of the adverse impacts and to help identify the optimal remedial activities. Also, the ecological risk assessment conducted after remediation may evaluate the effectiveness of the remedial option.

In contrast to human health risk assessment, which has an established methodology, the ecological risk assessment team has only recently reached agreement with Tennessee Department of Environment and Conservation on a strategy for conducting assessments of the risks posed to the environment. This strategy entails first identifying the impacts on the ecosystem and then tracing the causes or sources of the contamination. This strategy is more complex than the dose-response methodology used to calculate human health risks. The purpose of this section is to describe that strategy. No data on ecological risk are presented. Instead, the ecological risk assessment team will build on the data collected for the Biological Monitoring and Abatement project, described in Chapter 5 of this report. In late FY 1994 and FY 1995, the ecological risk team will evaluate how to use the data and data collection needs.

The ecological risk assessment process parallels the human health risk assessment process; however, human health risk assessment alone may fail to ensure protection of nonhuman biota. For example, nonhuman organisms are exposed to different concentrations of chemicals (e.g., a heron eats an entire fish instead of just the relatively less contaminated 
muscle that humans would eat). Also, exposure conditions often are very different (e.g., fish may live in and respire contaminated water that humans would come into contact with relatively infrequently). The ecological risk assessment evaluates risks to on-site and off-site biota under current conditions and considers a future scenario where loss of institutional controls allows reversion of the site to a natural state. Human health risk assessment places a greater emphasis on off-site risks and considers different land use practices.

\subsubsection{General Approach}

The ecological risk assessment employs the weight-of-evidence approach to integrate several types of information. The three principal lines of evidence are media contaminant concentrations, toxicity tests using contaminated site media, and surveys of site-associated biota. Media concentrations are compared to published toxicity data for individual contaminants, whereas media toxicity tests measure the effects of all contaminants in the medium at the time of collection. Biological surveys use resident biota as integrator of the cumulative site impacts.

An iterative hierarchical approach is used at the Oak Ridge Reservation (Suter et al. 1992). The lowest level is the individual waste site or source operable unit. These sites constitute the source of release to the wider environment, or integrator operable units. Integrator operable units receive and integrate the releases from multiple waste sites and other sources of contamination or disturbance.

Existing programs collect some of the required information for assessing the risks of waste sites to biota, and the ecological risk assessment team collaborates with these programs to obtain relevant data. For example, the Biological Monitoring and Abatement Project collects information useful to creek assessments (see Sect. 5). However, the ecological risk assessment has specific data needs not shared by Biological Monitoring and Abatement Project (e.g., whole-body fish analyses to determine risks to fish-eating wildlife). The aquatic component of Biological Monitoring and Abatement Project has been the major focus in the past. The Oak Ridge Reservation-wide assessment is in development and will address the terrestrial risks to biota.

The ORNL site is largely forested, and the forested area is predominantly natural (there are areas of planted pine and other species). However, this area is segmented by roads, buildings, and waste sites. The forested area, along with White Oak Creek and its tributaries, provides habitat for abundant wildlife. Wetlands and floodplains, as well as threatened and endangered species and their habitat, are receptors of special concern in the ecological risk assessment. There are floodplains associated with White Oak Creek and its tributaries and a number of wetlands around the ORNL site (Cunningham and Pounds 1991). No federally listed threatened and endangered species are known to be present. However, species that are listed by the state of Tennessee as threatened and endangered or "in need of management" are present, and the Oak Ridge Reservation falls within the range of some federally listed species (Kroodsma 1987; Parr 1992 cited in Etnier et al. 1992).

\subsubsection{Ecological risk assessment activities at ORNL}

During the past year, discussions of general in ecological risk assessment issues for the Oak Ridge Reservation have occurred among the Federal Facility Agreement parties and ORNL staff. These interactions have resulted in the establishment of the terrestrial integrator 
operable unit for the Oak Ridge Reservation, the mandating of a reservation-wide monitoring and assessment activity, clarification of the relationships between source and integrator operable units, and the development of generic ecological assessment endpoints and conceptual models. During the coming year these advances will be incorporated into a new approach and strategy for ecological risk assessment on the Oak Ridge Reservation, a sampling and analysis plan for the reservation-wide monitoring and assessment program, and the development of plans for individual source operable units and WAG 2 that incorporate the new ecological risk assessment strategy.

The relationship between operable units is depicted in Fig. 6.4. Contaminants deposited in the source operable units such as WAG 5 leach into the groundwater operable units (Melton Valley and Bethel Valley groundwater operable units), leach or are eroded into the aquatic integrator operable unit (WAG 2), and contaminate the terrestrial integrator operable unit (the Oak Ridge Reservation) primarily through contamination of wildlife that forage on the source operable units. Contaminants are exchanged among the groundwater, aquatic integrator, and terrestrial integrator operable units, and are transported to the off-site operable units (Poplar Creek embayment, Clinch River, and Lower Watts Bar Reservoir).

The conceptual models for ecological risk graphically represent the relationships between contaminant sources and endpoint receptors. They are not intended to show all possible sources, but rather the major routes of contaminant exposure and endpoint receptors. Conceptual models for operable units relevant to ORNL (source, aquatic integrator, groundwater, and terrestrial integrator) are presented in Figs. C-1 through C-5 of Appendix C are summarized in the following paragraphs.

Figure 6.4 illustrates the interrelationship between a source operable unit and the integrator operable units. Contaminant sources are the trenches, pits, sumps, spill sites, and other facilities in which wastes were deposited. The abiotic portion of the source operable unit includes mobile, waterborne contaminants (e.g., those in groundwater, runoff, eroded soil), aquatic systems within the source operable unit (ponds or streams distinct from the integrator operable unit), and surface soil in the operable unit. The biotic components, which are potential endpoint communities, include aquatic biota (i.e., fish, invertebrates, and aquatic plants) (Fig. C-2) and source operable unit-associated terrestrial organisms (i.e., plants, soil microbial community, small herbivores, small omnivores, and small soil invertebrate feeders). Herbivores, omnivores, and soil invertivores with home ranges too large for a distinct population on a source operable unit are included in the reservation-wide conceptual model. All piscivores are also included in the terrestrial integrator operable unit.

The conceptual model for the WAG 2, or aquatic integrator operable unit, is presented in Fig. C-3. Inputs from source operable units include surface water, groundwater (seeps and shallow groundwater), and eroded soils. For WAG 2 the intermediate pond is considered a source of in-operable unit disposed wastes. The abiotic components of WAG 2 include surface water (streams, ponds, springs and wetlands), sediments (streams, ponds, and woodlands), and floodplain soils. The biotic components, which are potential endpoint communities, include aquatic organisms (fish, invertebrates, and aquatic plants) (Fig. C-2) and floodplain-associated terrestrial organisms (plants, soil microbial community, small herbivores, small omnivores, and small soil invertebrate feeders). Herbivores, omnivores, and soil invertivores with home ranges too large for a distinct WAG 2 population are included in the reservation-wide conceptual model. All piscivores are also included in the terrestrial Integrator operable unit. 
6-14

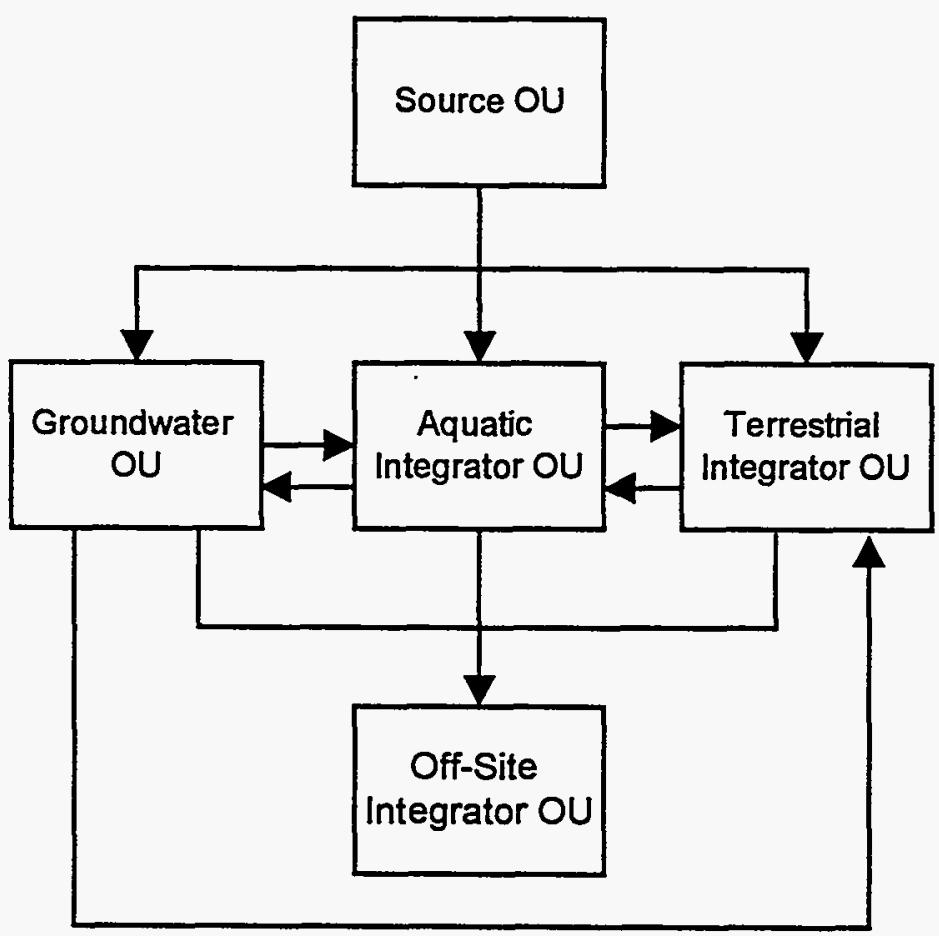

Fig. 6.4. Contaminant transfers among operable units. 
The conceptual model for the groundwater integrator operable unit is presented in Fig. C-4. Contaminants leach into this compartment from waste sources and contaminated soils. The abiotic components include the contaminated aquifer and seeps and springs, which are considered the sole vectors for contaminant transport to the terrestrial and aquatic integrator operable units. Although not usually considered in ecological risk assessments in the United States, the biotic components, which are potential endpoint communities, include aquifer biota (invertebrates and microbes) and cave aquatic biota (vertebrates, invertebrates, and microbes). Aquifer biota may be important to contaminant degradation and ultimate site remediation. Cave aquatic biota may include threatened or endangered species, though it is not clear what species may occur in caves on the Oak Ridge Reservation.

The terrestrial integrator operable unit is the Oak Ridge Reservation, which includes ORNL and the associated source and integrator operable units, and is presented in Fig. C-5. It is assumed that there are no contaminant sources in this operable unit, but rather that all inputs are from source and aquatic integrator operable units. The biotic components, which are potential endpoint communities, include organisms with home ranges too large to maintain a distinct population on an individual source or aquatic integrator operable unit. Upland plants are vascular plants, located outside source and aquatic integrator operable units, that take up contaminants from shallow groundwater.

\subsubsection{Challenges for ecological risk assessments at Oak Ridge Reservation}

Data quality objectives for CERCLA remedial investigations/feasibility studies have been developed through an informal process of planning and negotiation between responsible parties and regulators. However, recently there have been attempts to implement a more formal and standardized data quality objective process as described in Data Quality Objectives Process for Superfund (EPA 1993a).

Another issue that has caused difficulties in practice with respect to both health and ecological risks, but is not treated in the data quality objective guidance, is the dual goals of CERCLA assessments. The data quality objective guidance is designed to satisfy the important goal of supplying the information necessary to decide among remedial alternatives. However, another CERCLA goal is to characterize the risks so that the public and decision makers are fully informed of the consequences of alternative actions. Clearly, the data requirements of one goal may be different from the other.

If the formal data quality objective process is to be applied to ecological risks, rather than continuing the process of negotiating data quality objectives among the stakeholders, an effort must be made to adapt the guidance. Given the lack of guidance for how to perform ecological risk assessments, an attempt to simply force the ecorisk data quality objective guidance into the current mold is likely either to ignore the complexity of ecological risk assessment or to create a cumbersome and impractical procedure. Therefore, an approach for implementing ecological techniques in the data quality objective process is in development. The data quality objective process for the reservation-wide monitoring and assessment program provides a basis for development of such an approach. In particular, it supplies generic problem formulations, goals, and decision rules for ecological risk assessment. In the coming years it will be necessary to develop approaches for the rest of the data quality objective process in which the specific types and amounts of ecological data are specified. 


\subsection{SUMMARY}

Risk assessment provides a consistent way to evaluate hazards on- and off-site and to prioritize ER activities. To facilitate decision making, the ORNL site has been divided into source WAGs and integrator WAGs (WAG 2 and groundwater operable unit) which integrate contaminant releases from source units. The classification is based on the recognition that source control WAGs should be remediated prior to cleaning up the integrator WAGs. Further, data collected in the integrator units support decision making and risk assessment to prioritize the WAGs for remedial actions.

Because of the magnitude and complexity of contamination problems at ORNL, remedial activities must be prioritized. Risk management decisions must be made as to the priority of on-site hazards versus off-site hazards, which WAGs to remediate first, and which operable units within WAGs to remediate first. For site characterization, decisions must be made as to what contaminants pose the largest hazards, therefore requiring early attention, and what contaminants pose little risk and need not be investigated.

Primary mobile contaminants of concern identified in the surface water were ${ }^{90} \mathrm{Sr}$ and ${ }^{3} \mathrm{H}$. These same contaminants were also identified at high risk levels in many wells in the White Oak Creek watershed. Various metals and organics were identified in localized groundwater areas, although they are not found in the surface water in levels that would indicate a residential risk. The main contaminant of concern identified in the White Oak Creek watershed soil and sediments was ${ }^{137} \mathrm{Cs}$, based on current radiation exposure levels and the potential for a significant off-site release during a major storm event.

Ecological risks are conducted iteratively at the source-control operable units and expand to the aquatic, groundwater, and terrestrial integrator operable units. Source operable units contribute most of the contamination inputs to integrator operable units, and data collected during source investigations will support future integrator assessments. Implementation of a terrestrial integrator work plan and development of a source-to-integrator conceptual model will provide a framework for assuring data compatibility. Efforts to develop an approach for ecological data quality objectives will also assure a more standardized, integrated, and efficient approach to ecological risk assessment at ORNL.

Key issues to be addressed in risk assessment relate to (1) the ultimate use of the land, which affects risk scenarios and cleanup criteria, (2) the appropriate scale of ecological risk assessments that must be done on both a WAG basis and site-wide basis, and (3) the further integration of risk assessment into decision making. Risk assessment is a central component in WAG 2/SI Project activities, and results of these assessments are used to guide monitoring and sampling and to assist in the prioritization of major ER activities. With risk information, managers can focus and refine the site characterization process. After more rigorous baseline risk assessments, managers can identify alternative remedial actions. 


\section{SUMMARY}

The WAG 2/SI Project has a comprehensive, integrated approach for gathering the relevant environmental data in support of the ER Program's ORNL Site Office. During FY 1994, the work was divided into four major tasks (surface water, groundwater, soil and sediment, and biota). The objectives of these tasks were to

- summarize the results from environmental monitoring and data collection activities conducted during the past year by the WAG 2/SI Project and by other monitoring programs;

- report radionuclide flux and mass balance calculations for stream reaches between monitoring stations in White Oak Creek to gain more understanding of where radioactivity is accumulating or being mobilized in the system;

- describe recent advances in the fundamental understanding of hydrologic processes, whereby contaminants are mobilized and transported in surface and subsurface hydrologic systems; and

- provide assessment of both the monitored data and our knowledge of the contaminant transport processes to gain a reasoned perspective on the diversity, as well as the extent and movement, of contaminants.

- identify chemicals/radionuclides and their pathways that can potentially lead to unacceptable exposures to humans and the environment;

\subsection{SURFACE WATER}

The Watershed Hydrology Task group issued the annual comprehensive hydrologic data summary for CY 1993 (Borders et al. 1994). This is the fifth report in a series produced by the ER Program that supports the long-term collection of hydrologic data for determination of contaminant fluxes and risk assessments, and for engineering design of remedial actions.

The Seep Task staff continued to provide "snapshots" of the distribution of contaminants in WAG 2 and along the perimeters of contaminant source areas. Intensive monitoring along the southern edge of WAG 5 led to the identification of seep areas A, B, C, and D. In turn, a Removal Action has been initiated for the purpose of reducing the ${ }^{90} \mathrm{Sr}$ releases from seep areas $C$ and D. Sampling along the WAG 4 tributary identified the seepage sources of ${ }^{3} \mathrm{H}$ and ${ }^{90} \mathrm{Sr}$, and the data will assist the planned interim remedial action to be conducted there.

At the watershed scale, mass balance of the main radionuclides for major stream reaches in White Oak Creek watershed for 1993 indicated that Lower White Oak Creek/White Oak Lake Reach was a sink for ${ }^{137} \mathrm{Cs}$ (the previous year it was a source) and a source for ${ }^{90} \mathrm{Sr}$ and ${ }^{60} \mathrm{Co} ;{ }^{3} \mathrm{H}$ probably passed through this reach without much gain or loss. The discharge of ${ }^{3} \mathrm{H}$ 
at White Oak Dam was $1800 \mathrm{Ci}$ (less than in 1992) and the discharge of ${ }^{90} \mathrm{Sr}$ was $2.1 \mathrm{Ci}$ (identical to 1992).

Preliminary data, generated by the Tributary Assessment Task team, for the WAG 4 tributary clearly show the partial dilution of soluble contaminants that occurs during a storm-that is, the reduced concentration but increased flux of contaminants that occurs as discharge increases during the storm. This pattern has been seen at many places in the watershed, but the data also show the seasonal changes from storm to storm. These data, combined with an analysis of monthly water quality parameters, have led to an integrated ORNL conceptual hydrologic model. The monthly flow-proportional data collected at the major monitoring stations show that soluble contaminants $\left({ }^{90} \mathrm{Sr}\right.$ and $\left.{ }^{3} \mathrm{H}\right)$ are discharged at the highest rates in the late fall/early winter when the groundwater storage becomes filled and nearly all the rainfall is routed to streamflow. Thereafter, contaminant fluxes tend to diminish until the following fall/winter. The integrated conceptual model will assist staff in the interpretation of monitoring data, and it will provide the basis for future performance assessment of remedial actions at the watershed scale.

\subsection{GROUNDWATER}

Groundwater data collection activities at ORNL included ongoing sampling and analysis of the 160 wells at the WAG perimeters; investigations related to the remedial investigation at WAG 5; well sampling, analysis, and water level data collection at WAG 1 under postPhase 1 remedial investigation monitoring activity; water level monitoring at wells throughout the ORNL site; and hydraulic head measurement of 13 wells in the Hydrostatic Head Measurement Stations system. This report summarized monitoring at groundwater wells and groundwater modeling.

The previous summary of conditions in the WAG perimeter wells was reported in ERMA (1992) where the radionuclide concentrations across the system were mapped. The analysis reported herein identifies the risk level at each well partitioned into risk by radionuclides, metals, and organics. The most common contaminants that have been detected at least once in the wells are ${ }^{3} \mathrm{H},{ }^{90} \mathrm{Sr}$, and beryllium, although beryllium is typically at a moderately low level (less than $<5 \times 10^{-5}$ risk). Organics are not widespread, and they appear mostly in wells in WAGs $1,4,5$, and 6 . Risk levels have been summed for all contaminants reported for each well in the system.

The modeling staff has applied groundwater modeling techniques to problems of widely varying scale. The effect of impermeable caps on local flow patterns was investigated, and the results show the importance of shallow subsurface stormflow to the water budget and potential migration of contaminants. Modeling was applied to a WAG 6 monitoring problem where the water discharge rate along the ungaged perimeter had to be estimated. The results seem reliable because they have been reproduced by several methods. In addition, regional groundwater modeling is being conducted on the ORNL supercomputer, and the model has been expanded to include a larger spatial domain, including more WAGs. Lastly, fractureflow simulation is the other area of modeling investigation, and the first model application will be the Corehole 8 plume.

Extensive laboratory experiments coupled with a field investigation at WAG 5 are advancing our understanding of the mechanisms of contaminant transport via groundwater. 
Preferential flow in macropores combined with the effects of matrix diffusion have been demonstrated and quantified. These mechanisms that affect the movement of contaminants are important to the performance of remedial actions. If only primary sources (waste burial trenches) are remediated then secondary sources (contaminated soil/rock located down gradient) that are not remediated may release contaminants to streams for years, even decades.

The modeling staff is making steady progress in developing workable analytical tools to address ER groundwater problems. A good example is the assistance given to the WAG 6 monitoring and assessment team that needed an estimate of the groundwater discharge rate. Several years ago, the sheer complexity of the geological setting at ORNL was daunting to modelers, who had only conventional porous media models. In recent years, there has been significant progress, although there is considerable work remaining to represent quantitatively the fracture-flow system at field scales and to link models of the surface water and groundwater systems.

\subsection{SOIS AND SEDRMENTS}

The Sediment Transport Monitoring staff collected sequential samples of runoff at the major weirs during flood conditions to determine the discharge of sediment and associated ${ }^{137} \mathrm{Cs}$ in the White Oak Creek system. This information is important to the enhancement of the conceptual model of contaminant/sediment transport and to the calibration of the HSPF computer model. The calibrated model will be used to simulate the sediment discharge due to extreme storms. It will also be used to determine the effects of proposed remedial actions on erosion of contaminated sediments currently stored in floodplain and streambed lower White Oak Creek.

Data for the December 1993 storm, which has a precipitation return period of about 5 years, provided a contradictory picture relative to the storm results reported in ERMA (1993). As reported earlier, the March 1993 storm was rated a 2-year event, yet it resulted in about $60 \%$ more ${ }^{137} \mathrm{Cs}$ released at White Oak Dam than did the December 1993 storm. Moreover, the data show that the weir pools retained significant portions of sediments mobilized during the storm even though the weir pools already appeared to be filled near, or to, capacity. These storm monitoring results are important to ER because modeling efforts in FY 1995 based on these data will be used to assess whether or not there is a reasonable possibility that unacceptable amounts of ${ }^{137} \mathrm{Cs}$ and other contaminants could move off-site, leading to potential risk to individuals living downstream on the Clinch River.

Several tasks have been initiated to characterize and quantify the sediment/contaminant inventories in the watershed and the erosion rates. Erosion pins placed in stream banks allow soil loss to be measured after large storms. The data suggest that at locations near the Intermediate Holding Pond site, known to be highly contaminated, the stream-bank erosion averaged $3.3 \mathrm{~cm} / \mathrm{storm}$ for three extreme storms (>2-year return period). This amount is judged significant, but it is uncertain at this point how to interpret the stream-bank erosion data throughout the White Oak Creek channel network. A separate regional study of longterm erosion rates suggests that 44-year average soil loss for the watershed may be about 1 ton acre $^{-1}$ year $^{-1}$; this tentative value may assist in modeling historical conditions at ORNL. 


\subsection{BIOTA}

Biological monitoring is conducted through the Biological Monitoring and Assessment Program, which has both compliance monitoring objectives and ER ecological risk objectives. In Sect. 5, results were reported for the component programs: toxicity monitoring, bioaccumulation studies, indicators of contaminant stress, in-stream ecological monitoring, and radioecological studies of White Oak Lake.

Most of the results of these component investigations are merged in the integrated assessment, designed to evaluate if the aquatic system at ORNL is suitable for growth and propagation of aquatic life, livestock watering, and wildlife. The assessment includes a reach-by-reach analysis of the data collected at monitoring stations in the White Oak Creek system. In the assessment, Fifth Creek, First Creek, White Oak Creek, in the main plant area; and the remainder of White Oak Creek to White Oak Lake, are all impacted to some degree, and they are less than fully suitable to support aquatic life. Fifth Creek has improved in the past and was stable in 1993. First Creek showed some evidence of decline, whereas White Oak Lake conditions (especially the fish population) have improved in recent years, although some lake parameters are still below reference levels. Other streams (Northwest Tributary and Melton Branch) are suitable to support aquatic life. Upper White Oak Creek is generally suitable for supporting life, but there is a source of toxicity in the stream before the main plant area.

To discern risk posed to livestock and wildlife, contaminant uptake by fish and selected indicator organisms was assessed in White Oak Creek. Fish have elevated mercury and PCB levels; largemouth bass have elevated ${ }^{137} \mathrm{Cs}$; raccoons have elevated PCBs and ${ }^{137} \mathrm{Cs}$; and aquatic vegetation contains ${ }^{137} \mathrm{Cs}$ and ${ }^{60} \mathrm{Co}$, which are transferred to migratory waterfowl. Remains of a kingfisher bird contained measurable cadmium and mercury. The data indicate that wildlife is acquiring generally low-level contamination on the ORNL site and that livestock watered on the site probably would as well.

Biological monitoring has been performed continuously for 8 years. The results generally show a highly impacted, relatively stable ecosystem that is in some cases improving, mostly because of reductions in point-source discharges.

\subsection{RISK ASSESSMENT}

Risk assessment activities in support of source operable units and WAG 2 (1) describe the approach of human health risk assessments and use the results to identify contaminants of concern for different media, (2) track risk assessments by WAG and source operable unit, and (3) update prioritization of WAGs and source operable units based on risk evaluations so ER management can address the scheduling and allocation of resources in a rational framework. Ecological risk assessment is not as well advanced as that for human health because of the complexities inherent to ecology, as described in Sect. 6.3 of this report.

The water ingestion pathway, combined with water quality data, is used to determine the risk level at the outflow point at ORNL (White Oak Dam) and to determine relative risk from WAGs and operable units based on perimeter monitoring of the WAG or operable unit. While the risk indicator exceeds at the White Oak Dam for 1993 was calculated to be $5.9 \times 10^{-4}$, which exceeds the U.S. Environmental Protection Agency target goal of $1 \times 10^{-4}$, 
the public does not have any access to this effluent that would provide prolonged exposure. The nearest access point for prolonged exposure is at Clinch River mile 9.5, and dilution to that point reduces risk levels by a factor of about 100, leading to risk levels on the order of $1 \times 10^{-6}$.

An analysis of 7 years of monthly flow data at White Oak Dam indicates that ${ }^{90} \mathrm{Sr}$ and ${ }^{3} \mathrm{H}$ are the only soluble contaminants that individually exceed the $1 \times 10^{-4}$ probability of lifetime excess cancers. No noncarcinogens exceed the hazard index of 1 . Over time, risk resulting from ${ }^{3} \mathrm{H}$ decreased relative to ${ }^{90} \mathrm{Sr}$, partly because of the shorter half-life of ${ }^{3} \mathrm{H}$ but also because of declining releases of ${ }^{3} \mathrm{H}$.

The WAGs have been prioritized for remediation based on risk caused by contaminants discharged from them that have been transported in the surface water system . In Table 6.1, WAG 5 was shown to contribute $59 \%$ of off-site risk, followed by WAG 1 (18\%), and WAG $4(17 \%)$ with other WAGs contributing $4 \%$ or less. The main contaminants comprising the off-site risk are ${ }^{3} \mathrm{H}$ and ${ }^{90} \mathrm{Sr}$.

As discussed in Sect. 1, current early actions in progress at ORNL address these contaminant sources. At WAG 5, the construction of an interception system to control contamination at seeps $C$ and $D$ is under way. Early actions for the Corehole 8 plume in WAG 1 and for contaminated seeps in WAG 4 will be initiated early in FY 1995. In keeping with this approach to prioritization, remediation of WAG 6 , which contributes only about $2 \%$ to off-site risk, has been deferred until the larger sources of contamination have been cleaned up.

For groundwater, the risk assessment approach is different, because the public has no access to contaminated groundwater at ORNL. The assessment strategy for the groundwater operable unit involves general characterization on a well-by-well and subcatchment basis. The groundwater operable unit focuses on preventing any further deterioration of the groundwater quality at ORNL. Analysis of groundwater concentrations by WAGs indicates that ${ }^{90} \mathrm{Sr}$ and ${ }^{3} \mathrm{H}$ are the two carcinogens that typically exceed the $1 \times 10^{-4}$ risk, along with beryllium and several organic compounds. Several metals and some organics exceed the hazard index of 1 .

Human health risk issues that require attention are (1) the uncertainty in risk calculations and incorporation of uncertainty in decision making; (2) education about the subjective nature inherent to risk analysis-allowing risk assessment to be used as a consensus building tool rather than a method for confirming risk perceptions; and (3) the critical role of future land use on present ER decisions.

During the past year, discussions of ecological risk assessment between DOE staff, regulators, and ORNL staff have resulted in overall guidelines. Agreement has been reached on (1) establishment of the Oak Ridge Reservation as a terrestrial integrator operable unit, (2) mandating of a reservation-wide biological monitoring and assessment activity, (3) clarification of the relationships between ecological source operable units and ecological integrator operable units, (4) and the development of generic ecological assessment endpoints and conceptual models. During the coming year these advances will be incorporated into a new approach and strategy for ecological risk assessment. The ecological risk assessment will build on data collected in the Biological Monitoring and Abatement Program as well as chemical and radiological data from soils and water. New data must also be gathered, but the assessment project has not yet identified in detail what information is needed. 


\subsection{ADDITIONAL DATA NEEDS AND UPCOMING EFFORTS}

The data quality objective workshop held in June 1994 allowed WAG2/SI project leaders, DOE representatives, and regulators to discuss the progress of the WAG 2 Remedial Investigation project. It was agreed that Phase I of the remedial investigation should be completed in FY 1995, as proposed in the original plan (ORNL 1990) and that the monitoring component identified as Phase II should begin. The purposes of Phase I were initial characterization, screening risk assessment, and identification of any need for an early remedial action or corrective measure. Also, part of the data quality objective agreement between the participants was that WAG 2 should be narrowly defined by the WAG boundaries and that CERCLA matters should address only the contaminants in the WAG and the biota that live in or utilize the WAG. Consequently, much of the water sampling should be eliminated from the WAG 2 remedial investigation because the soluble contamination has its origin in upstream WAGs, not WAG 2.

The remaining tasks in the Phase I remedial investigation are intended to identify whether any early actions are needed in WAG 2 to prevent unacceptable off-site risks and determine if there is any unacceptable ecological risk. The two main tasks for the coming year are to (1) complete the HSPF computer simulation assessment of possible unacceptable offsite risk resulting from mobilization and transport of contaminated sediments currently deposited in WAG 2 and (2) initiate data collection to support the biological assessment at WAG 2. Actual field work in support of these two tasks has not been defined.

Long-term monitoring to be considered for Phase II of the WAG 2 remedial investigation also relates to sediment transport and ecological risk, although the tasks have not been identified.

Monitoring and analysis currently conducted under the SI portion of the program will be separated and developed as a special support function for the ORNL ER Program and for the individual removal actions and remedial actions at the operable units. ORNL site-wide environmental monitoring in support of ER objectives will be collected in the Groundwater Area-Wide Program and a Surface Water Area-Wide Program. The groundwater component was already moved out of the WAG 2/SI Project early in FY 1994. In contrast, a surface water program plan will be developed late in FY 1994 for start-up in the following fiscal year after DOE review and approval. The program will emphasize assessment activities to address specific ORNL ER issues and data collection to support the needed assessments. The surface water program will also include all biological monitoring needed to support ORNL ecological risk assessment at all levels. 


\section{REFERENCES}

Akin, E. (U.S. Environmental Protection Agency Risk Assessment Manager, Region IV, Atlanta). 1994. Personal communication on May 12, 1994, to C. W. McGinn, Martin Marietta Energy Systems Environmental Restoration Risk Assessment Manager.

Ashwood, T. L., ed. 1993. Seventh Annual Report on the ORNL Biological Monitoring and Abatement Program. Draft ORNL/TM. Oak Ridge National Laboratory, Oak Ridge, Tennessee.

Ashwood, T. L., ed. 1994. Eighth Annual Report on the ORNL Biological Monitoring and Abatement Program. Draft ORNL/TM-12767. Oak Ridge National Laboratory, Oak Ridge, Tennessee.

Atwood, G. P., and D. E. Miller. 1992. Quality Assurance Plan for the Remedial Investigation of Waste Area Grouping 2 at Oak Ridge National Laboratory. ORNL/ER-134. Oak Ridge National Laboratory, Oak Ridge, Tennessee.

Blaylock, B. G., M. L. Frank, F. O. Hoffman, L. A. Hook, G. W. Suter, and J. A. Watts. 1992. Screening of Contaminants in Waste Area Grouping 2 at Oak Ridge National Laboratory. ORNL/ER-62/R1. Oak Ridge National Laboratory, Oak Ridge, Tennessee.

Blaylock, B. G., M. L. Frank, L. A. Hook, F. O. Hoffman, and C. J. Ford. 1993. White Oak Creek Embayment Site Characterization and Contaminant Screening Analysis. ORNL/ER-81. Oak Ridge National Laboratory, Oak Ridge, Tennessee.

Borders, D. M., R. B. Clapp, D. S. Hicks, and M. F. Tardiff. 1993. "Surface Water," Section 3, Second Annual Report of the Environmental Restoration Monitoring and Assessment Program at Oak Ridge National Laboratory. ORNL/ER-180. Oak Ridge National Laboratory, Oak Ridge, Tennessee.

Borders, D. M., D. K. Reece, J. A. Watts, B. J. Frederick, W. M. McCalla, and K. S. Ziegler. 1994. Hydrologic Data Summary for the White Oak Creek Watershed at Oak Ridge National Laboratory, Oak Ridge, Tennessee (January-December 1993). Draft ORNL/ER. Oak Ridge National Laboratory, Oak Ridge, Tennessee.

Cox, D. K., N. D. Farrow, W. C. Kyker, M. A. Faulkner, and L. M. Stubbs. 1991. The New Definitive Map of White Oak Lake. ORNL/TM-11204. Oak Ridge National Laboratory, Oak Ridge, Tennessee.

Cunningham, M., and L. Pounds. 1991. Resource Management Plan for the Oak Ridge Reservation: Wetlands on the Oak Ridge Reservation (V. 28). ORNL/NERP-5/V28. Oak Ridge National Laboratory, Oak Ridge, Tennessee.

DOE (U.S. Department of Energy). 1992a. Oak Ridge Reservation Site Management Plan for the Environmental Restoration Program. DOE/OR-1001/R2. Oak Ridge, Tennessee. 
DOE (U.S. Department of Energy). 1992b. Interim Record of Decision (IROD) for ORNL WAG 13 Cesium Plots, Oak Ridge National Laboratory, Oak Ridge, Tennessee. DOE/OR-1059\&D4. Oak Ridge National Laboratory, Oak Ridge, Tennessee.

DOE (U.S. Department of Energy). 1992c. Proposed Plan for the Oak Ridge National Laboratory Waste Area Grouping 6 Interim Remedial Action. DOE/OR-995\&D3. Oak Ridge National Laboratory, Oak Ridge, Tennessee.

DOE (U.S. Department of Energy). 1993a. Environmental Monitoring Plan for Waste Area Grouping 6 at Oak Ridge National Laboratory, Oak Ridge, Tennessee. DOE/OR/01-1192\&D1. Oak Ridge National Laboratory, Oak Ridge, Tennessee.

DOE (U.S. Department of Energy). 1993b. Interim Record of Decision (IROD) for ORNL WAG 11 Surface Debris, Oak Ridge National Laboratory, Oak Ridge, Tennessee. DOE/OR-1055\&D4. Oak Ridge National Laboratory, Oak Ridge, Tennessee.

DOE (U.S. Department of Energy). 1993c. Treatability Study Work Plan for In Situ Vitrification of Seepage Pit 1 in WAG 2 at Oak Ridge National Laboratory, Oak Ridge, Tennessee. DOE/OR/01-1158\&D2. Oak Ridge National Laboratory, Oak Ridge, Tennessee.

DOE (U.S. Department of Energy). 1993d. Phase I Remedial Investigation Report of Waste Area Grouping 2 at Oak Ridge National Laboratory, Oak Ridge, Tennessee. DOE/OR/01-1179\&D1. Oak Ridge National Laboratory, Oak Ridge, Tennessee.

DOE (U.S. Department of Energy). 1994a. Remedial Investigation Work Plan for the Groundwater Operable Unit at Oak Ridge National Laboratory, Oak Ridge, Tennessee. DOE/OR/01-1252\&D1. Oak Ridge National Laboratory, Oak Ridge, Tennessee.

DOE (U.S. Department of Energy). 1994b. Remedial Investigation/Baseline Risk Assessment for the Gunite and Associated Tanks Operable Unit at Waste Area Grouping 1 at Oak Ridge National Laboratory, Oak Ridge, Tennessee. DOE/OR/02-1275\&D1. Oak Ridge National Laboratory, Oak Ridge, Tennessee.

EBASCO. 1993. WAG 6 Interim Remediation Design Criteria Studies Results of $3 D$ and $2 D$ Groundwater Flow Modeling. U.S. Department of Energy, Oak Ridge Field Office, Environmental Restoration and Waste Management Program, Oak Ridge, Tennessee.

Eckermann, K. F. 1993. DFINT Version 4.0: A Code to View the Dosimetric Data of ICRP. ICRP Publication 30 Parts 1-4. Oak Ridge National Laboratory, Oak Ridge, Tennessee.

Energy Systems (Martin Marietta Energy Systems, Inc.). 1992. Oak Ridge Reservation Environmental Report for 1991, Vol. 2: Data Presentation, ES/ESH-22/V2, Oak Ridge National Laboratory, Oak Ridge, Tennessee.

EPA (U.S. Environmental Protection Agency). 1986. Authorization to Discharge under the National Pollutant Discharge Elimination System, Permit No. TN0002941, Oak Ridge National Laboratory (X-10) and Fact Sheet, April 1, 1986. U.S. Environmental Protection Agency, Washington, D.C.

EPA (U.S. Environmental Protection Agency). 1989. Risk Assessment Guidance for Superfund, 
Volume 1: Human Health Evaluation Manual (Part A). EPA/540/1-89-002. U.S. Enviromental Protection Agency, Washington, D.C.

EPA (U.S. Environmental Protection Agency). 1992. Handbook of Vitrification Technologies for Treatment of Hazardous and Radioactive Waste. EPA/625/R-92/002. U.S. Environmental Protection Agency, Washington, D.C.

EPA (U.S. Environmental Protection Agency). 1993a. Data Quality Objectives Process for Superfund. EPA/540/G-93/071. U.S. Environmental Protection Agency, Washington, D.C.

EPA (U.S. Environmental Protection Agency). 1993b. Health Effects Assessment Summary Table (HEAST): Annual Update, FY 1993. Office of Research and Development, U.S. Environmental Protection Agency, Washington, D.C.

ERMA. 1992. Annual Report of the Environmental Restoration Monitoring and Assessment Program at the Oak Ridge National Laboratory for FY 1991. R. B. Clapp, ed. ORNL/ER-124. Oak Ridge National Laboratory, Oak Ridge, Tennessee.

ERMA. 1993. Annual Report of the Environmental Restoration Monitoring and Assessment Program at the Oak Ridge National Laboratory for FY 1992. R. B. Clapp and J. A. Watts, eds. ORNL/ER-180. Oak Ridge National Laboratory, Oak Ridge, Tennessee.

Etnier, E. L., E. P. McDonald, and L. M. Houlberg. 1992. Applicable or Relevant and Appropriate Requirements (ARARs) for Remedial Actions at the Oak Ridge Reservation. $A$ Compendium of Major Environmental Laws. Oak Ridge National Laboratory, Oak Ridge, Tennessee.

Goldberg, P. Y. (coord.), S. E. Gheesling, J. C. Gideon, S. M. Gregory, L. V. Hamilton, B. M. Horwedel, R. S. Loffman, M. C. Salmons, and M. M. Stevens. 1993a. Environmental Surveillance Data Report for the First Quarter of 1993. ORNL/M-3022. Oak Ridge National Laboratory, Oak Ridge, Tennessee.

Goldberg, P. Y. (coord.), S. E. Gheesling, J. C. Gideon, S. M. Gregory, L. V. Hamilton, B. M. Horwedel, R. S. Loffman, M. C. Salmons, and M. M. Stevens. 1993b. Environmental Surveillance Data Report for the Second Quarter of 1993. ORNL/M-3023. Oak Ridge National Laboratory, Oak Ridge, Tennessee.

Gough, M., and J. D. Wilson. 1993. If Risk Assessment Ain't a Science, What Is It? Office of Technology Assessment, Washington D.C.

Gwo, J. P., P. M. Jardine, G. V. Wilson, and G. T. Yeh. 1994a. A multi-pore-region concept to modeling mass transfer in subsurface media. Journal of Hydrology (in press).

Gwo, J. P., P. M. Jardine, G. V. Wilson, and G. T. Yeh. 1994b. Advective-diffusive mass exchange and local-scale physical nonequilibrium: A sensitivity analysis. Water Resources Research (in press).

Hicks, D. S., D. K. Solomon, and N. D. Farrow. 1992. Investigation of Groundwater Flow Zones and Contaminant Transport in Solid Waste Storage Area 5 at Oak Ridge National Laboratory, Oak Ridge, Tennessee. ORNL/ER-154. Oak Ridge National Laboratory, Oak 
Ridge, Tennessee.

Hoffman, F. O., B. G. Blaylock, M. L. Frank, L. A. Hook. E. L. Etnier, and S. S. Talmage. 1991. Preliminary Screening of Contaminants in the Off-Site Surface Water Environment Downstream of the U.S. Department of Energy Oak Ridge Reservation. ORNL/ER-9. Oak Ridge National Laboratory, Oak Ridge, Tennessee.

Huff, D. D., and B. J. Frederick. 1984. Hydrologic Investigations in the Vicinity of the Proposed Centeral Waste Disposal Facility, Oak Ridge National Laboratory, Tennessee. ORNL/TM-9354. Oak Ridge National Laboratory, Oak Ridge, Tennessee.

ICRP (International Commission on Radiological Protection). 1990. Recommendations of International Commission on Radiological Protection. Oxford: Pergamon Press; Publication 60; Ann. ICRP 21(1-3).

Jardine, P. M., G. V. Wilson, and R. J. Luxmoore. 1988. Modeling the transport of inorganic ions through undisturbed soil columns from two contrasting watersheds. Soil Sci. Soc. Am. J. 52:1252-1259.

Jardine, P. M., G. K. Jacobs, and G. V. Wilson. 1993. Unsaturated transport processes in undisturbed heteogeneous porous media: I. Inorganic contaminants. Soil Sci. Soc. Am. J. 57:945-953.

Kroodsma, R. L. 1987. Resource Management Plan for the Oak Ridge Reservation, Vol. 24: Threatened and Endangered Animal Species, ORNL/ESH-1/24. Oak Ridge National Laboratory, Oak Ridge, Tennessee.

Lee, R. R., A. H. Curtis, L. M. Houlberg, S. T. Purucker, M. F. Tardiff, and D. E. Wolf. 1994. Site Characterization Plan for Groundwater in Waste Area Grouping 1 at Oak Ridge National Laboratory, Oak Ridge, Tennessee. DOE/OR/01-1194\&D2, ORNL/ER-248. Oak Ridge National Laboratory, Oak Ridge, Tennessee.

Loar, J. M., ed. 1991. Fifth Annual Report on the ORNL Biological Monitoring and Abatement Program. Draft ORNL/TM-12143. Oak Ridge National Laboratory, Oak Ridge, Tennessee.

Lomenick, T. F., and D. A. Gardiner. 1965. The occurrence and retention of radionuclides in sediment of White Oak Lake. Health Phys. 11:567-577.

MacIntosh, D. L., G. W. Suter II, and F. O. Hoffman. 1992. Model of the PCB and mercury exposure of mink and great blue heron inhabiting the off-site environment downstream from the U.S. Department of Energy Oak Ridge Reservation. ORNL/ER-90. Oak Ridge National Laboratory, Oak Ridge, Tennessee.

Maurer, R. J. 1992. An Aerial Radiological Survey of the Oak Ridge Reservation. EGG-10617-1229. EG\&G Energy Measurements, Inc., Las Vegas, Nevada.

Miller, P. D., C. W. McGinn, S. T. Purucker, and R. K. White. 1994. Defining the Role of Risk Assessment in the Comprehensive Environmental Response, Compensation, and Liability Act Remedial Investigation Process at the DOE-OR. ES/ER/TM-58. Oak Ridge National Laboratory, Oak Ridge, Tennessee. 
NAS/NRC (National Academy of Sciences/National Research Council). 1980. The Effects of Population Exposure to Low Levels of Ionizing Radiation. National Academy Press, Washington, D.C.

NAS/NRC (National Academy of Sciences/National Research Council). 1990. Health Effects to Exposures of Low-Levels of Ionizing Radiation. National Academy Press, Washington, D.C.

NCRP (National Council on Radiation Protection and Measurements). 1993. NCRP Report 116. Bethesda, Maryland.

Newsom, T. J., S. Blair, D. S. Hicks, and R. H. Ketelle. 1993. Source Areas Investigation Plan and Recommendation for Removal Actions at Waste Area Grouping 5 at Oak Ridge National Laboratory, Oak Ridge Tennessee. ORNL/ER-165. Oak Ridge National Laboratory, Oak Ridge, Tennessee.

Oakes, T. W., W. F. Ohnesorge, J. S. Eldridge, T. G. Scott, D. W. Parsons, H. M. Hubbard, O. M. Sealand, K. E. Shank, and L. D. Eyman. 1982. Technical Background Information for the ORNL Environmental and Safety Report, Vol. 5: The 1977 Clinch River Sediment Survey Data Presentation. ORNL-5878. Oak Ridge National Laboratory, Oak Ridge, Tennessee.

O'Brien, R., and P. M. Jardine. 1994a. Experimental characterization of mass transport processes in undisturbed macroporous media.Amer. Geophys. Union, p. 124. May 23-27, 1994. Baltimore, Maryland.

O'Brien, R., and P. M. Jardine. 1994b. Experimental characterization of mass transport processes in undisturbed macroporous media. In Agronomy Abstracts, American Society of Agronomy, November 1994, Madison, Wisconsin.

O'Brien, R., and P. M. Jardine. 1994c. Quantifying contaminant advective and diffusive mass transfer processes in subsurface heterogeneous weathered shales. (In preparation for peer review in Water Resources Research).

ORNL (Oak Ridge National Laboratory). 1990. Remedial Investigation Plan for Waste Area Grouping 2 at Oak Ridge National Laboratory, Oak Ridge, Tennessee. ES/ER-14\&D1. Oak Ridge National Laboratory, Oak Ridge, Tennessee.

Reedy, O. C., P. M. Jardine, and H. M. Selin. 1994a. Flow interruption: A proposed remediation technique to enhance subsurface contaminant removal. Emerging Technologies for Hazardous Waste Management. Am. Chem. Soc., Sept. 19-21, 1994. Atlanta, Georgia.

Reedy, O. C., P. M. Jardine, and H. M. Selin. 1994b. Quantifying diffusive mass transfer of non-reactive solutes in undisturbed soil columns using flow interruption. In Agronomy Abstracts, American Society of Agronomy, November 1994, Madison, Wisconsin.

Sanford, W. E., D. K. Solomon, and R. G. Shropshire. 1994. Noble gases as groundwater tracers in fractured saprolite. American Geophysical Union, p. 147, May 23-27, 1994, Baltimore, Maryland.

Sherwood, C. B., and J. M. Loar. 1986. Environmental Data for the WOC/WOL Watershed. ORNL/TM-10062. Oak Ridge National Laboratory, Oak Ridge, Tennessee. 
Solomon, D. K. G. K. Moore, L. E. Toran, R. B. Dreier, and W. M. McMaster. 1992. Status Report, A Hydrologic Framework for the Oak Ridge Reservation. ORNL/TM-12026. Oak Ridge National Laboratory, Oak Ridge, Tennessee.

Solomon, D. K., G. K. Moore, L. E. Toran, R. B. Dreier, and W. M. McMaster. 1992. Supplement to a Hydrological Framework for the Oak Ridge Reservation. ORNL/TM-12191. Oak Ridge National Laboratory, Oak Ridge, Tennessee.

Suter, G. W., II, A. Redfearn, R. K. White, and R. A. Shaw. 1992. Approach and Strategy for Performing Ecological Risk Assessments for the Department of Energy Oak Ridge Field Office Environmental Restoration Program. ES/ER/TM-33. Oak Ridge National Laboratory, Oak Ridge, Tennessee.

Tucci, P. 1992. Hydrology of Melton Valley at Oak Ridge National Laboratory, Tennessee. USGS Water Resources Investigations Report 92-4131.

West, O. M., and L. E. Toran. 1994. Development of a Three-Dimensional Groundwater Flow Model for Westem Melton Valley: Application of P-FEM to a DOE Waste Site. ORNL/TM-12474. Oak Ridge National Laboratory, Oak Ridge, Tennessee.

Wickliff, D. S., D. K. Solomon, and N. D. Farrow. 1991. Preliminary Investigation of Processes That Affect Source Term Identification. ONRL/ER-59. Oak Ridge National Laboratory, Oak Ridge, Tennessee.

Wilson, G. V., P. M. Jardine, and J. P. Gwo. 1992. Modeling the hydraulic properties of a multiregion soil. Soil Sci. Soc. Am. J. 56:1731-1737.

Wilson, G. V., P. M. Jardine, J. D. O’Dell, and M. Collineau. 1993. Field-scale transport from a buried line source in unsaturated soil. J. HydroL 145:83-109.

Wojtowicz, J. A., and J. G. Smith. 1992. Biological Monitoring and Abatement Program (BMAP) Benthic Macroinvertebrate Monitoring Project Sample Processing QA Plan. QAP-X-91-ES-077. Oak Ridge National Laboratory, Oak Ridge, Tennessee. 


\section{APPENDIX A}

This appendix contains eight graphs of the monthly fluxes during 1993 for ${ }^{3} \mathrm{H}$, total strontium, ${ }^{137} \mathrm{Cs}$, and ${ }^{60} \mathrm{Co}$ at two different stream reaches. The first reach is along the middle of White Oak Creek, and the second reach is at lower White Oak Creek near White Oak Dam. In these graphs, WCWEIR is identified as MS3 and MBWEIR is identified as MS4. 
(intentionally left blank) 
ORNL.DWG 94M-10064

Tritium (Middle WOC)

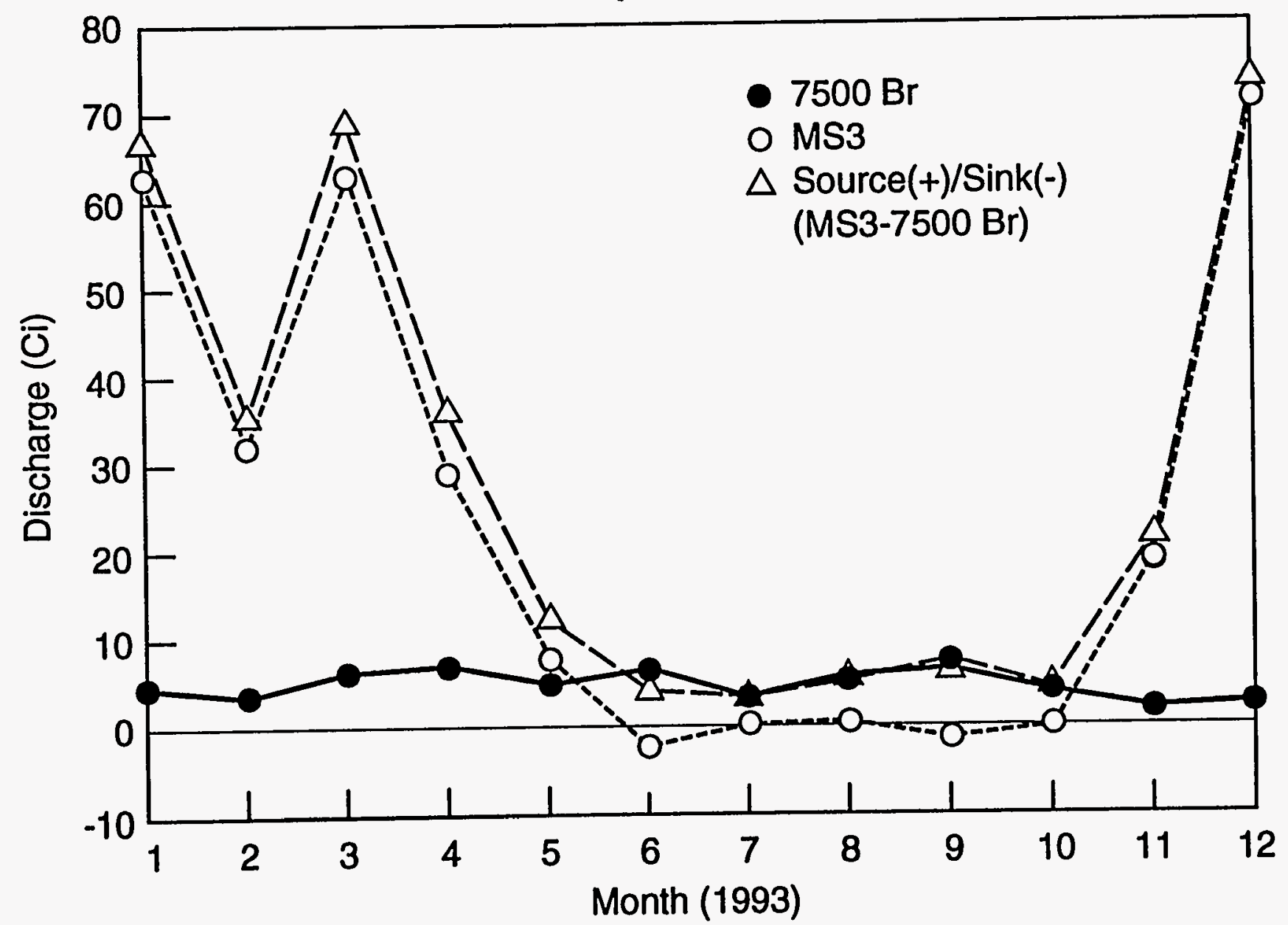

Fig. A1. Monthly ${ }^{3} \mathrm{H}$ discharge at gaging stations located in Middle White Oak Creek in 1993. 


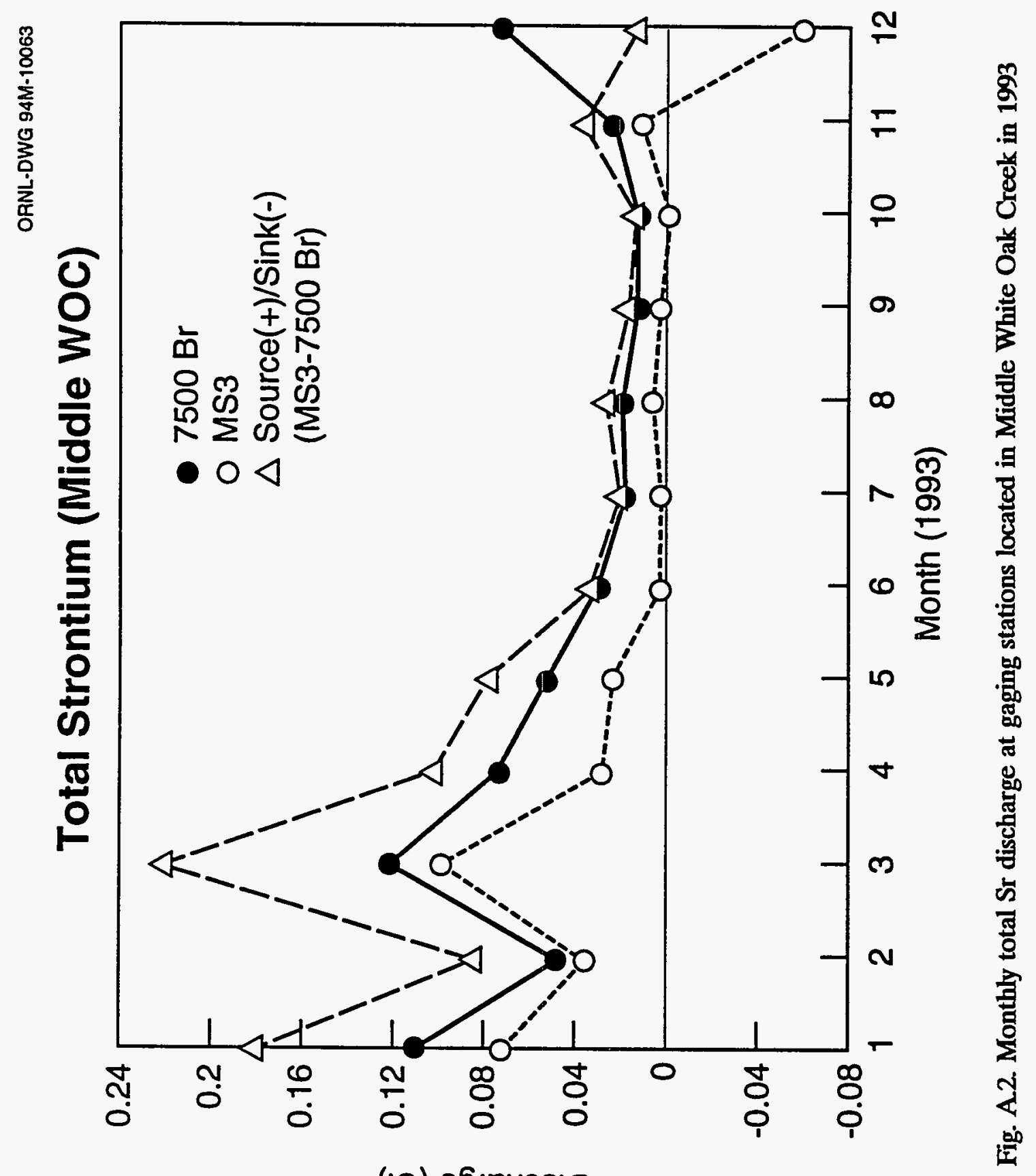

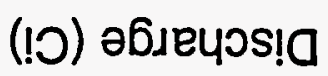




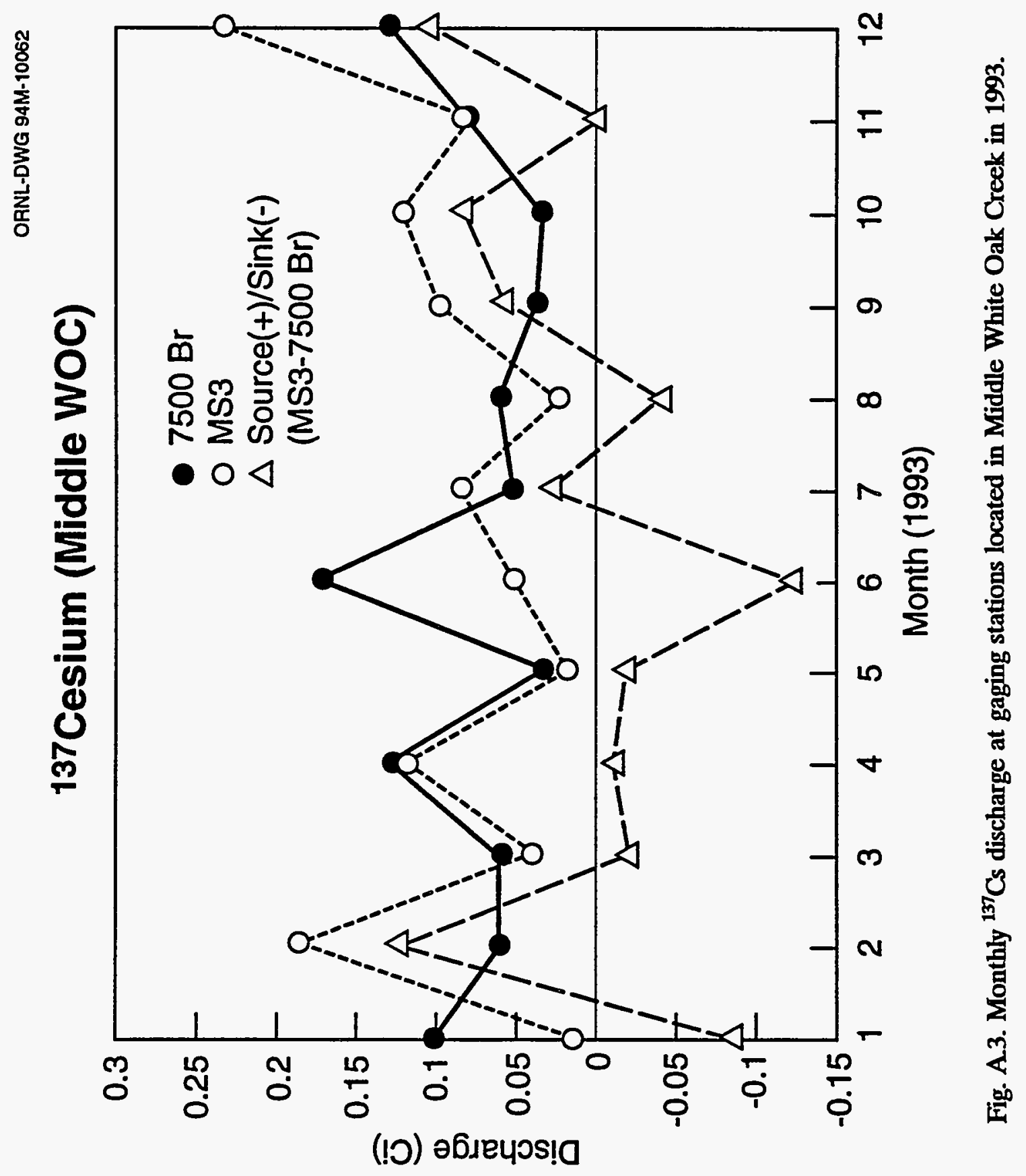




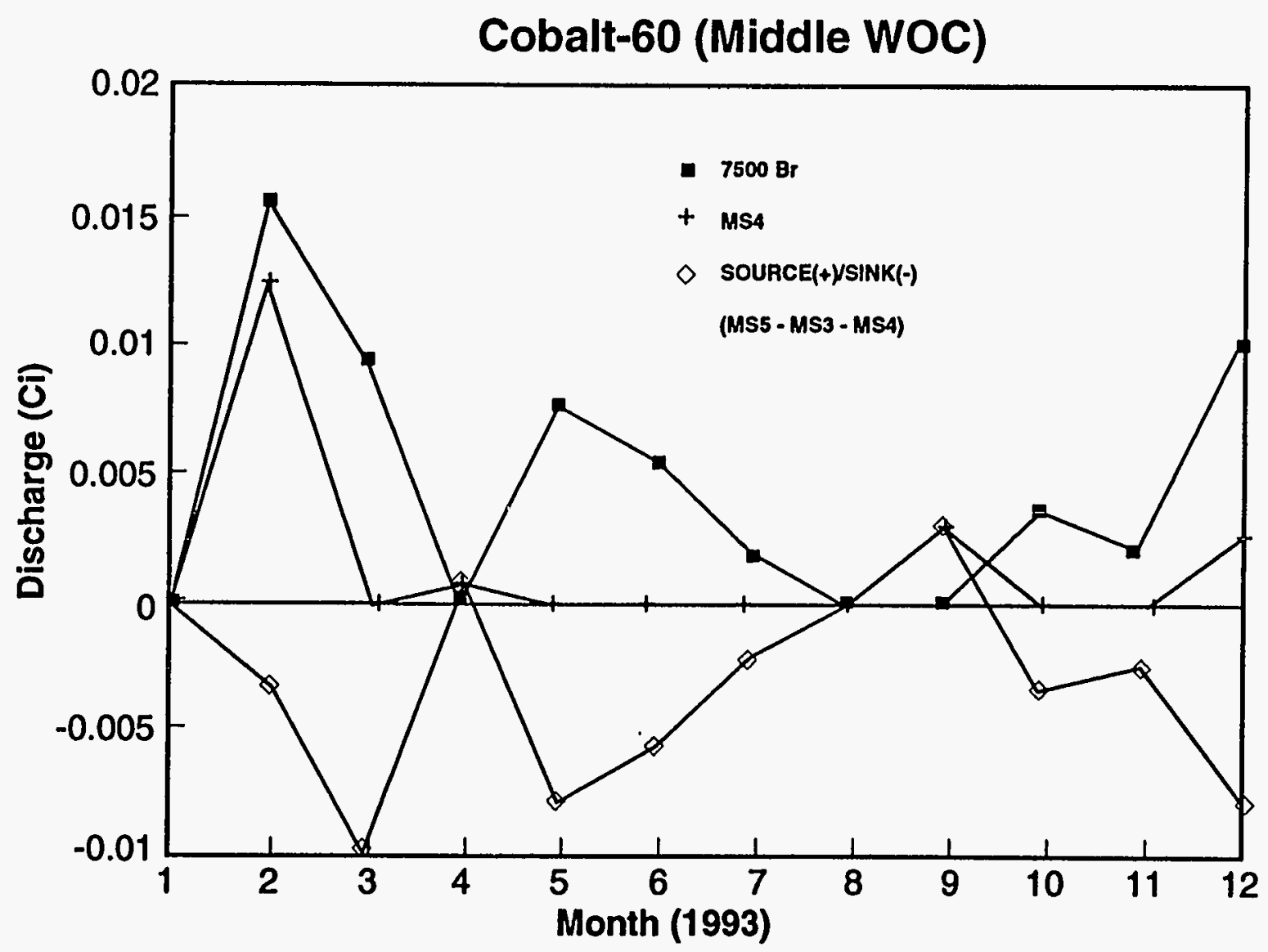

Fig. A4. Monthly ${ }^{60} \mathrm{Co}$ discharge at gaging stations located in Middle White Oak Creek in 1993. 


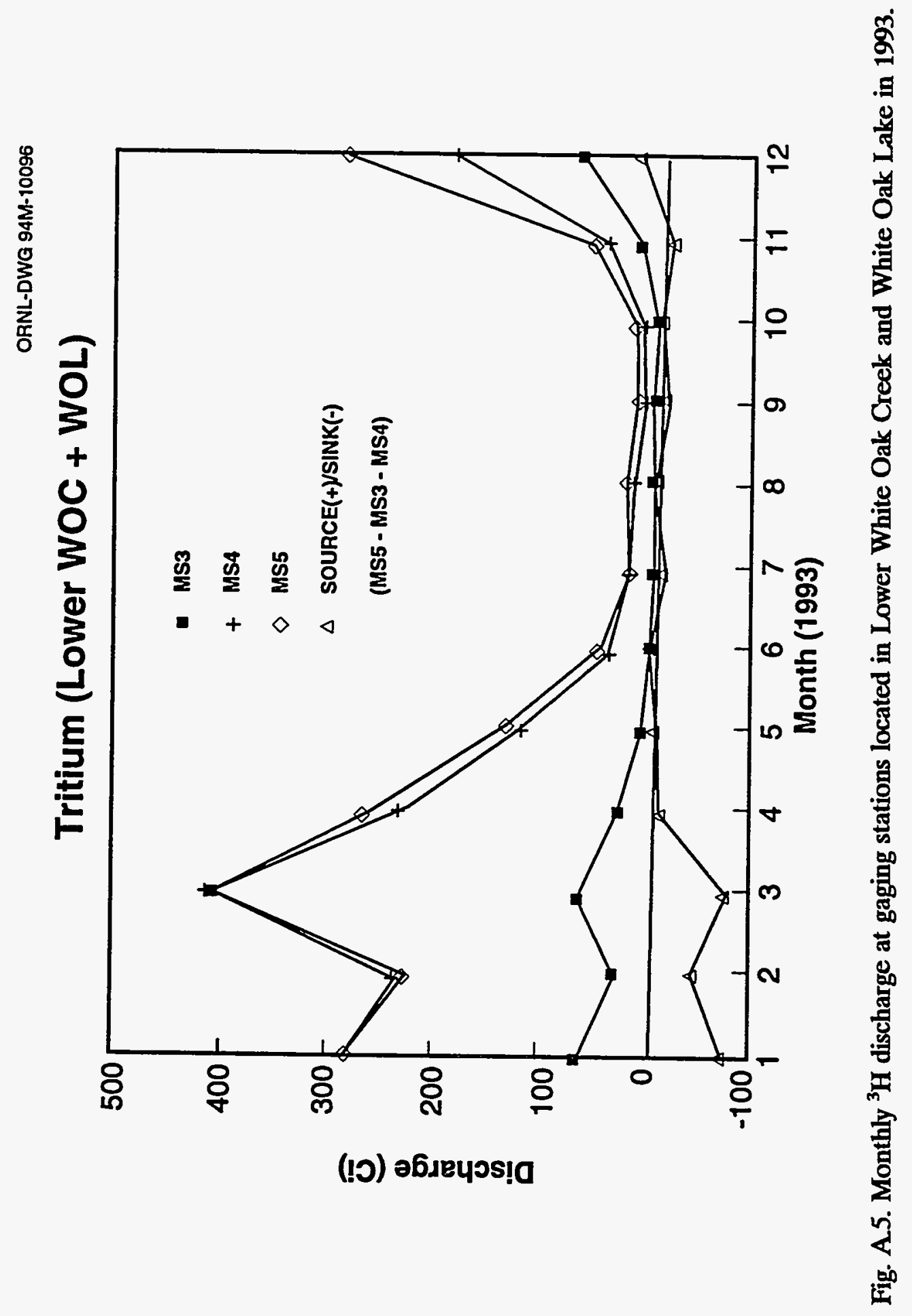




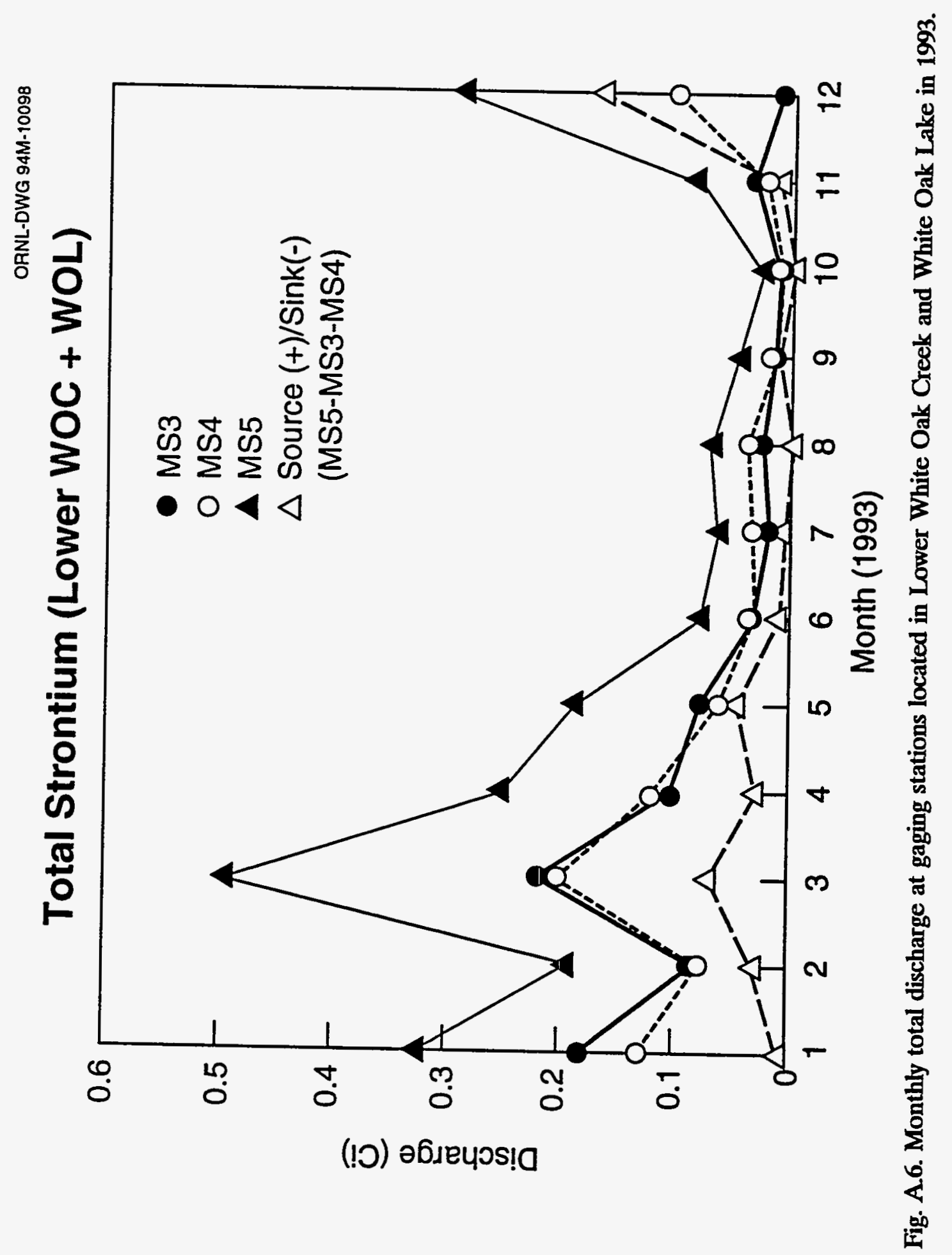




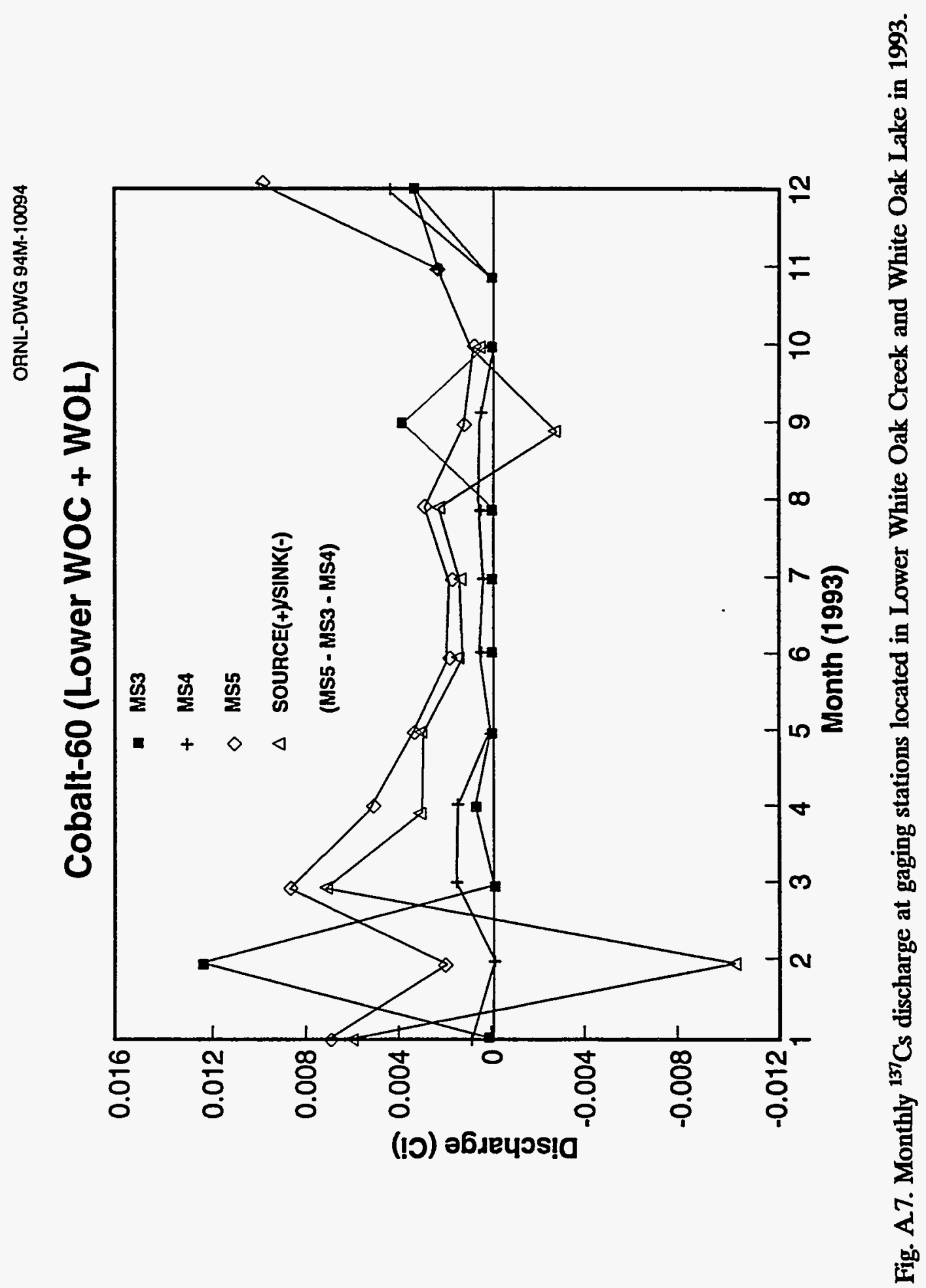


ORNL-DWG 94M-10080

Cesium-137 (Lower WOC + WOL)

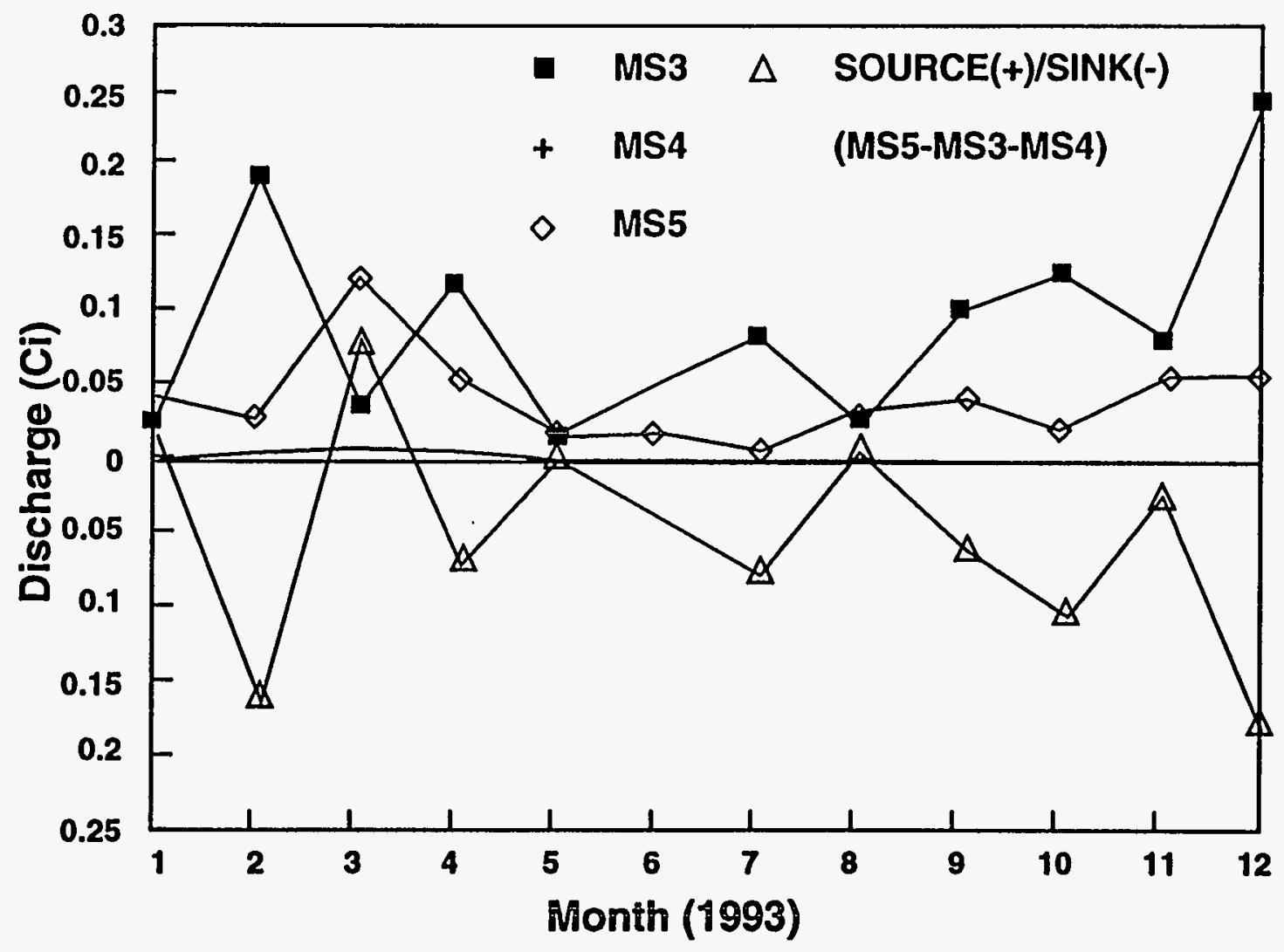

Fig. A.8. Monthly ${ }^{60} \mathrm{Co}$ discharge at gaging stations located in Lower White Oak Creek and White Oak Lake in 1993. 


\section{APPENDIX B}

This appendix presents four graphs of the risk history from wells in WAGs 1,4 , and 5. Contaminants contributing to the total risk calculations include tritium, vinyl chloride, strontium, 1,1-dichloroethene, trichloroethene, uranium-234, and chloroform. The time-history plots of risk and contaminant concentrations are stable for practical purposes. Some wells show increases or decreases in contaminant concentrations. No general statement accurately describes the changes of potential risk or contaminant concentration at ORNL. 
B-2

(intentionally left blank) 
ORNL-DWG 94M-10058

\section{Risk History at WAG 5 Well 973, Risk Group 1}

(Total risk and risk from largest contributors, those accounting for at least $90 \%$ of the total risk)

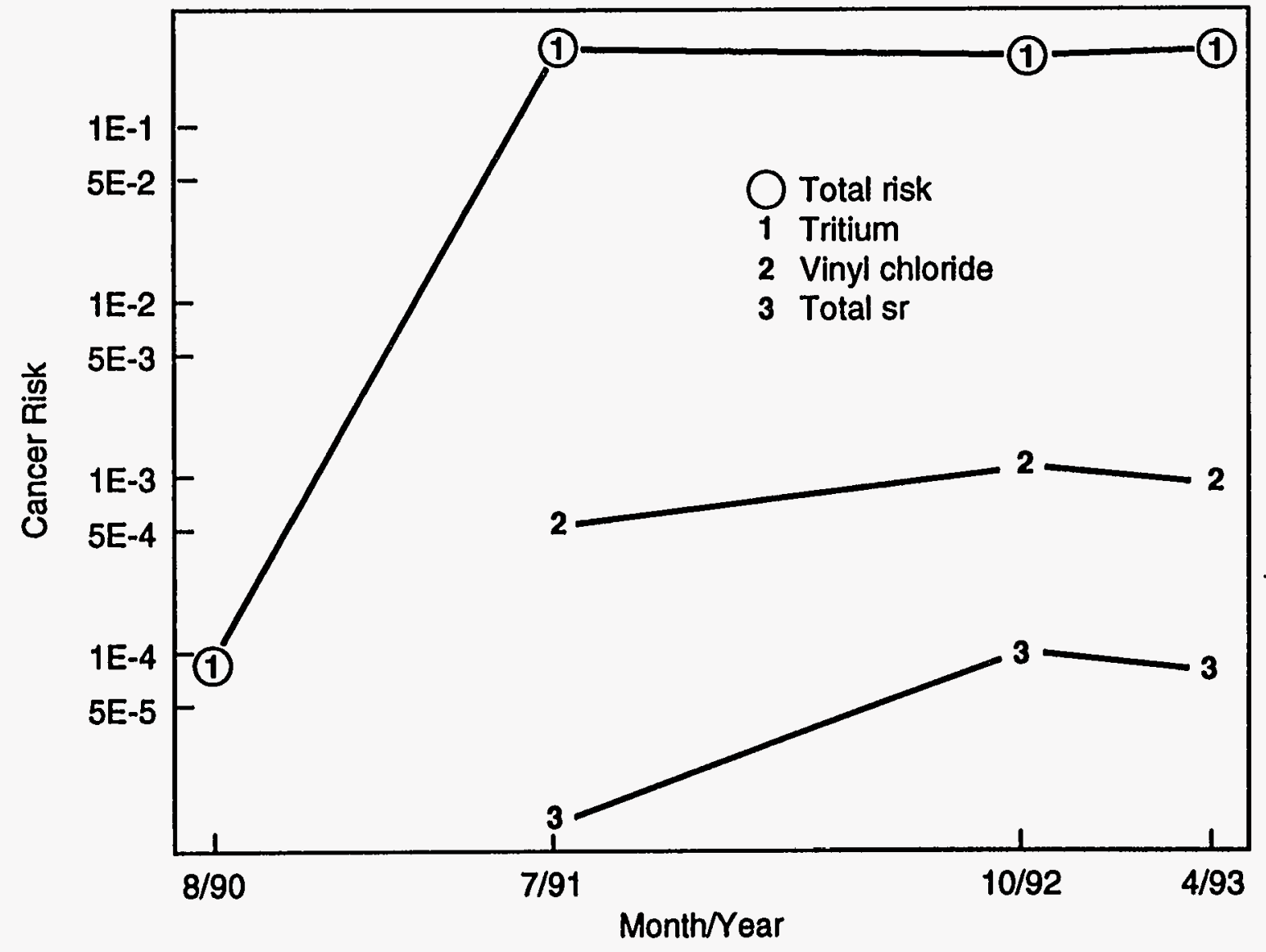

Fig. B.1. Risk history at WAG 5 well 973, risk group 1. 


\section{Risk History at WAG 4 Well 958, Risk Group 2}

(Total risk and risk from largest contributors, those accounting for at least $90 \%$ of the total risk)

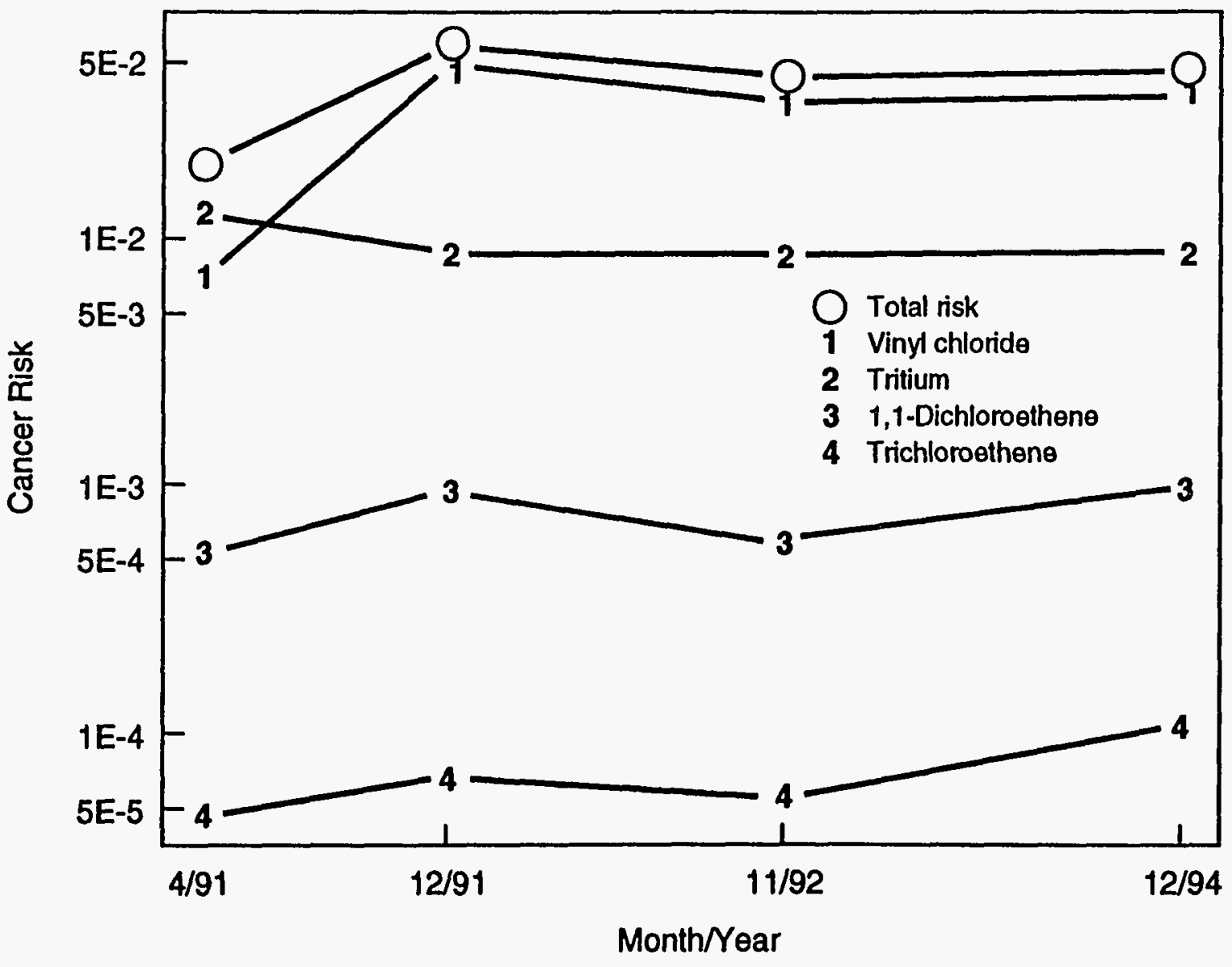

Fig. B.2. Risk history at WAG 4 well 958, risk group 2. 
ORNL-DWG 94M-10060

\section{Risk History at WAG 4 Well 954, Risk Group 2}

Total risk and risk from largest contributors, those accounting for at least $90 \%$ of the total risk)

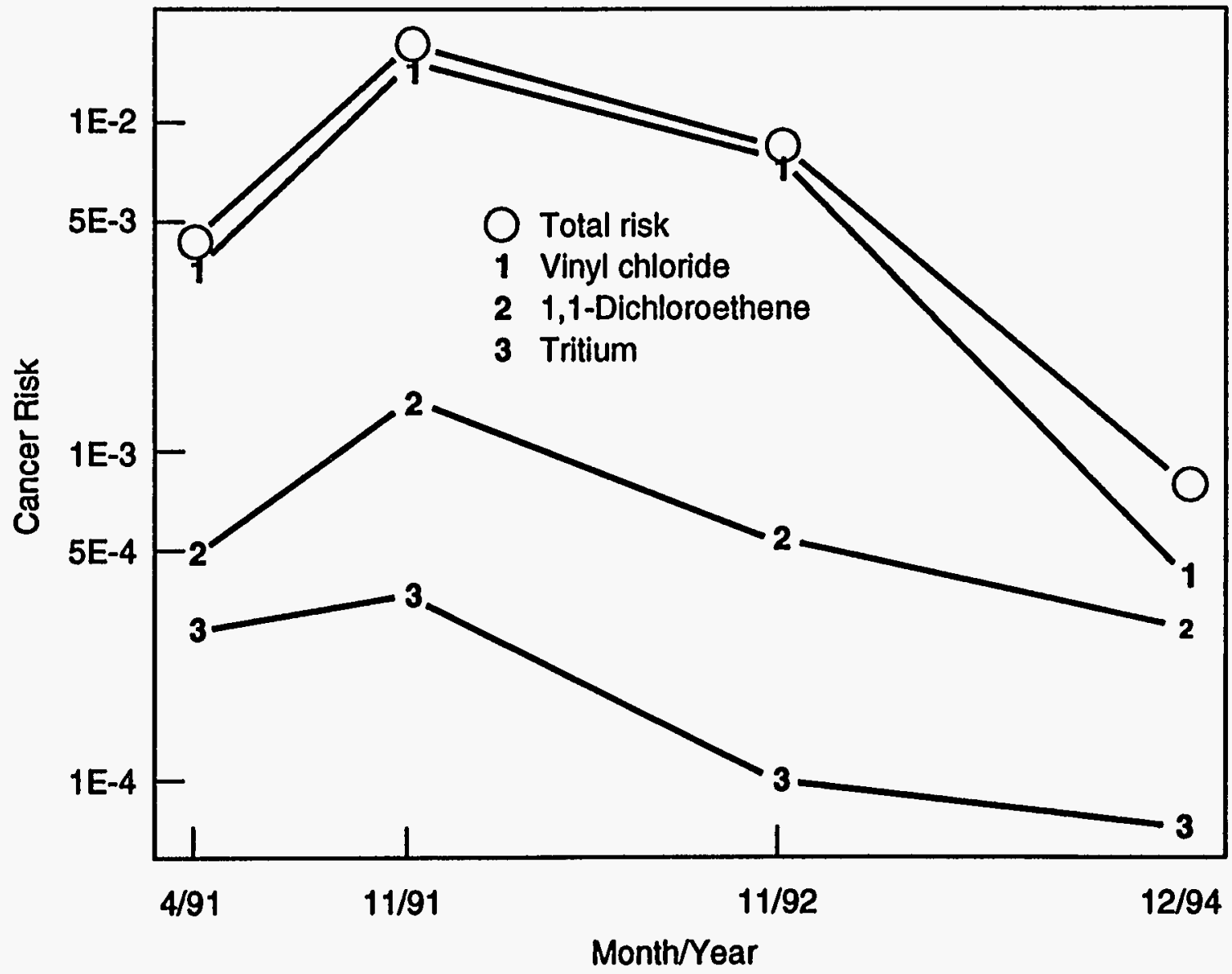

Fig. B.3. Risk history at WAG 4 will 954, risk group 2. 
ORNL.DWG 94M-10061

Risk History at WAG 1 Well 812, Risk Group 3

(Total risk and risk from largest contributors, those accounting for at least $90 \%$ of the total risk)

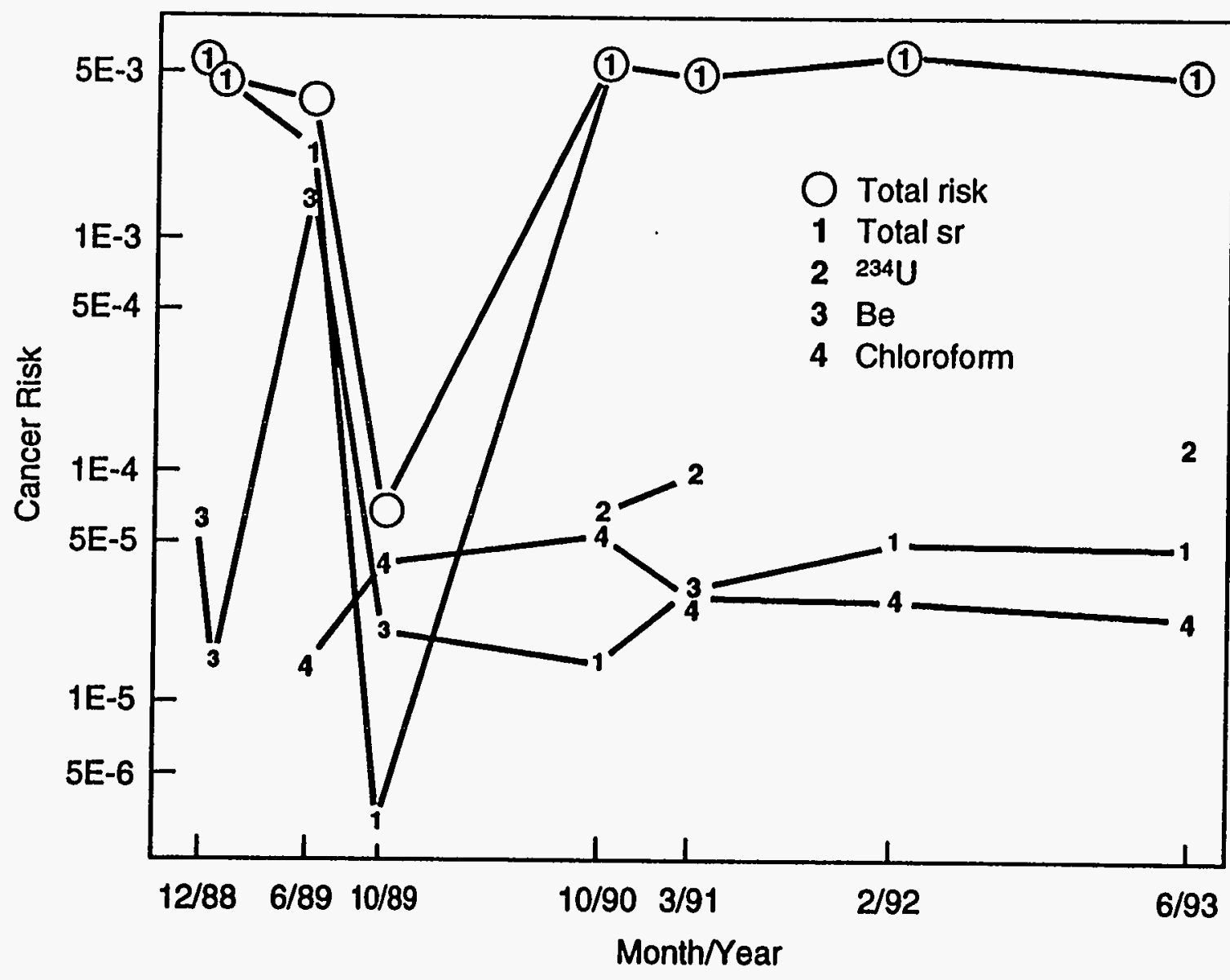

Fig. B.4. Risk history at WAG 1 well 812, risk group 3. 
Appendix C

FIGURES FROM ECOLOGICAL RISK SECTION 6.3 
C-2

(intentionally left blank) 


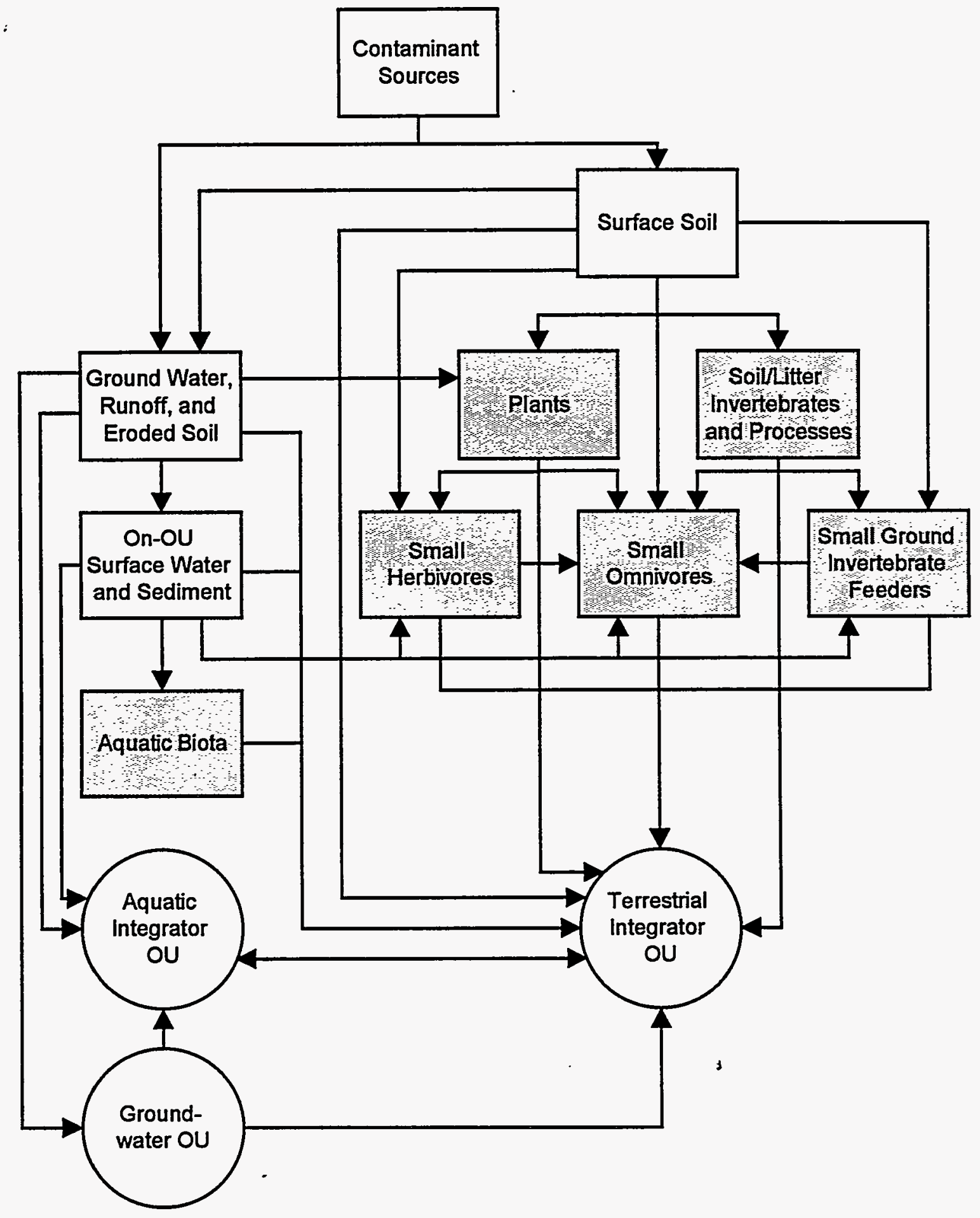

Fig. C.1. Contaminant transfers among operable units. 


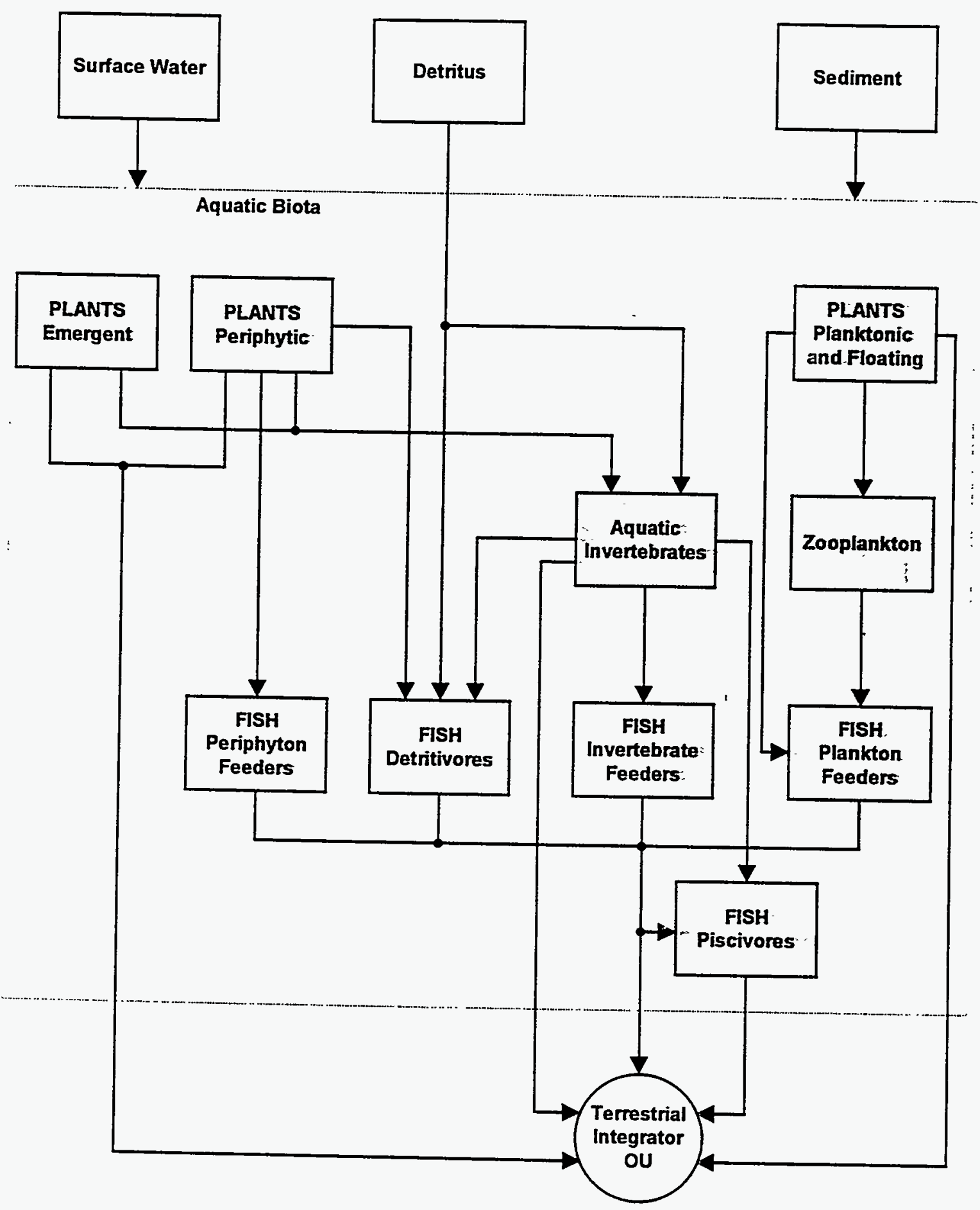

Fig. C.2 Aquatic biota compartment for source and aquatic integrator operable units. 


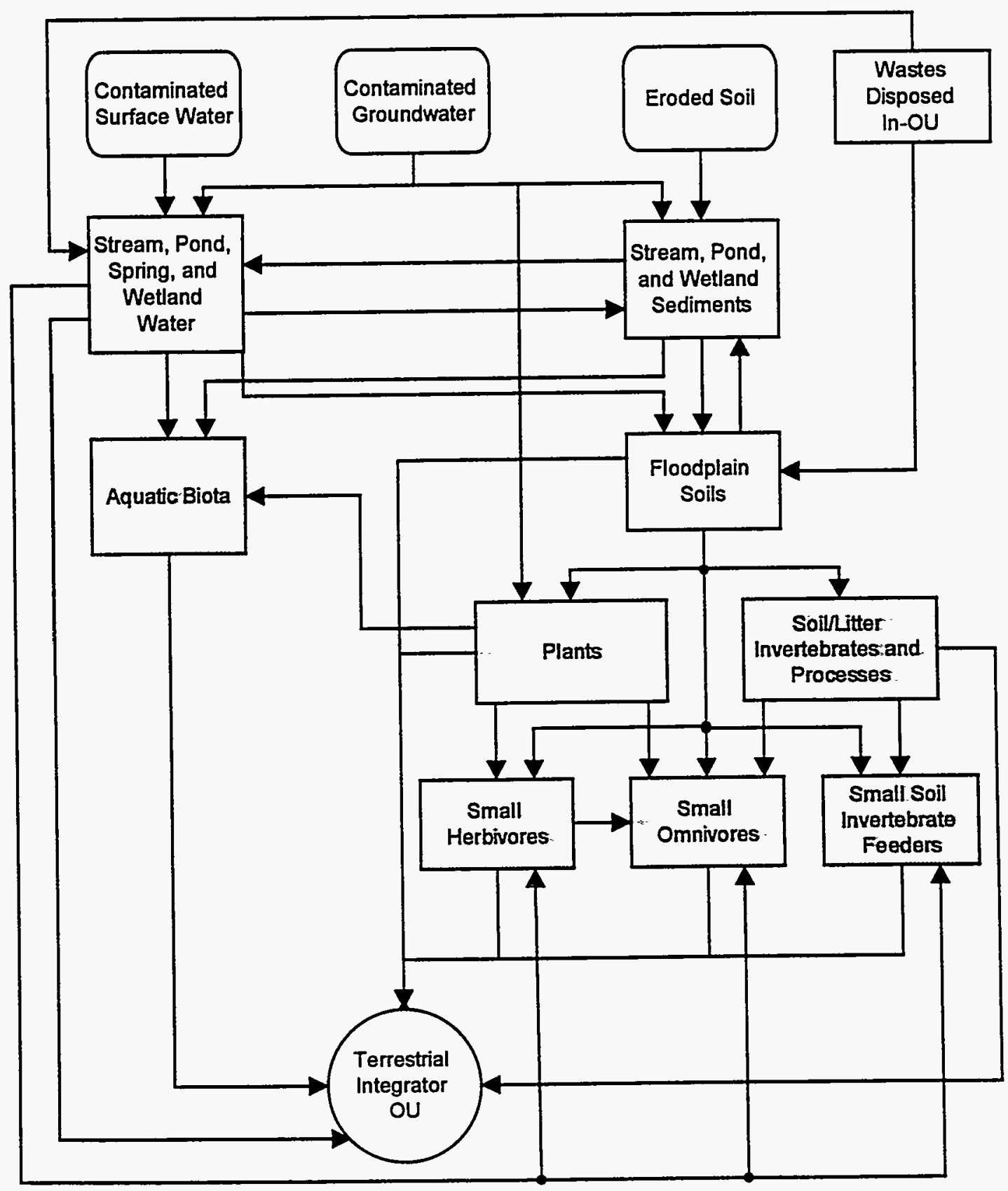

Fig. C.3. Transfer of contaminants into and through an aquatic integrator operable unit. 


\section{C-6}

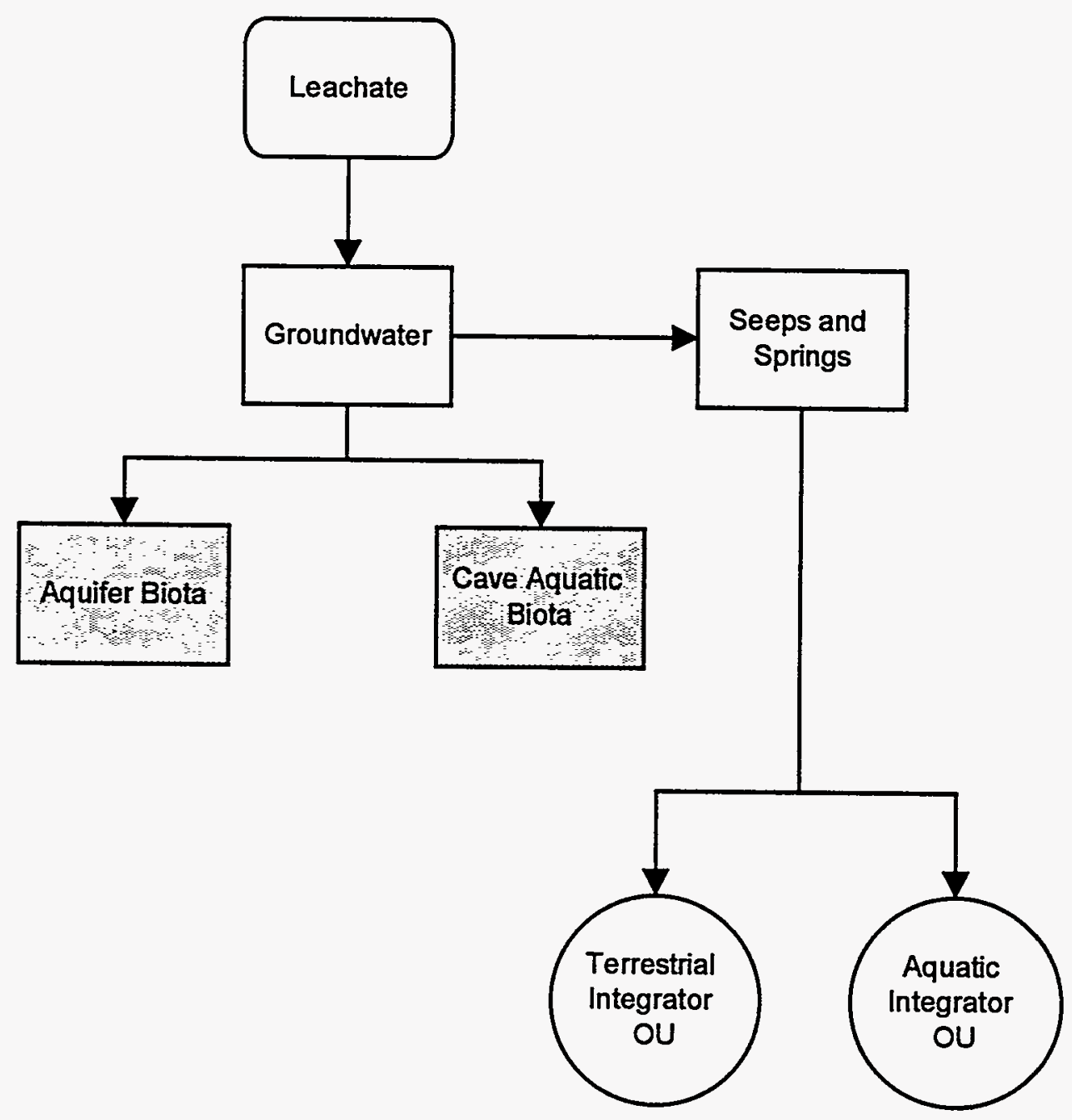

Fig. C.4. Transfer of contaminants into and through a groundwater integrator operable unit. 


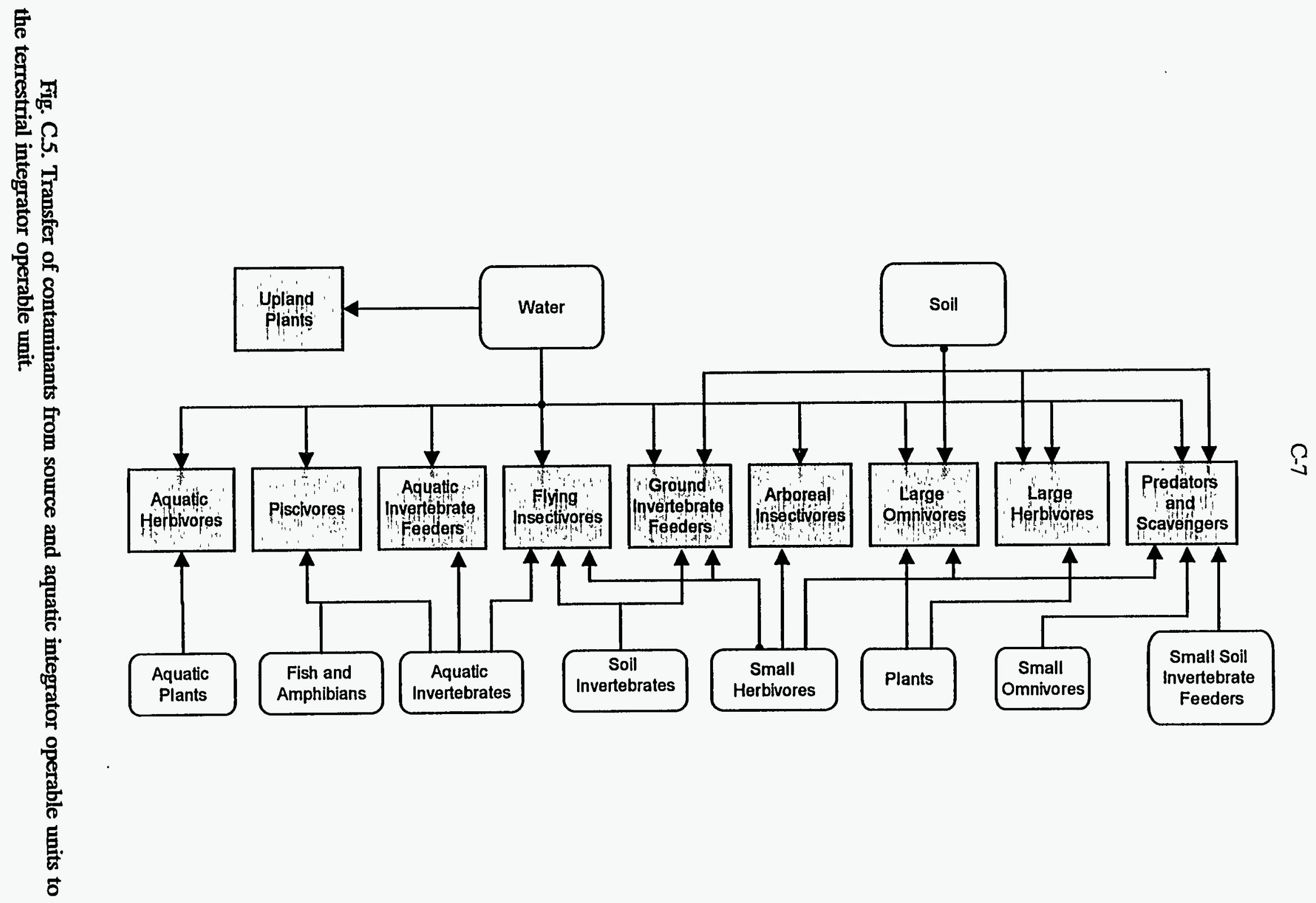


DOE/OR/01-1290\&D1

ORNL/ER-250\&D1

\section{DISTRIBUTION}

1. W. D. Brickeen

2. H. L. Boston

3-4. R. B. Clapp

5. M. F. P. DeLozier

6. S. B. Garland

7. S. E. Herbes

8. D. S. Hicks

9. S. G. Hildebrand

10. D. D. Huff

11. R. H. Kettelle

12. A. J. Kuhaida, Jr.

13-15. D. M. Matteo

16. D. E. Miller

17. J. B. Murphy

18-19. P. T. Owen

20. D. E. Reichle

21. P. A Schrandt

22. S. H. Stow

23. M. F. Tardiff

24. J. R. Trabalka

25. S. D. Van Hoesen

26. D. R. Watkins

27. J. A. Watts

28. P. S. Wood

29. Central Research Library

30-32. ESD Library

33-35. ORNL ER Doc. Mgmt. Center-RC

36-38. Central ER Doc. Mgmt. Center

39. Laboratory Records Department

40. ORNL Patent Section

41. Office of Assistant Manager for Energy Research and Development, DOE Oak Ridge Operations Office, P.O. Box 2001, Oak Ridge, TN 37831-8600

42. Dr. T. A. Fontaine, Civil and Environmental Engineering Department, South Dakota School of Mines and Technology, 501 E. St. Joseph St., Rapid City, SD 57701-3995

43. J. T. Sweeney, DOE Oak Ridge Operations Office, P.O. Box 2001, Oak Ridge, TN 37831-8541

44-45. Office of Scientific and Technical Information, P.O. Box 62, Oak Ridge, TN 37831 